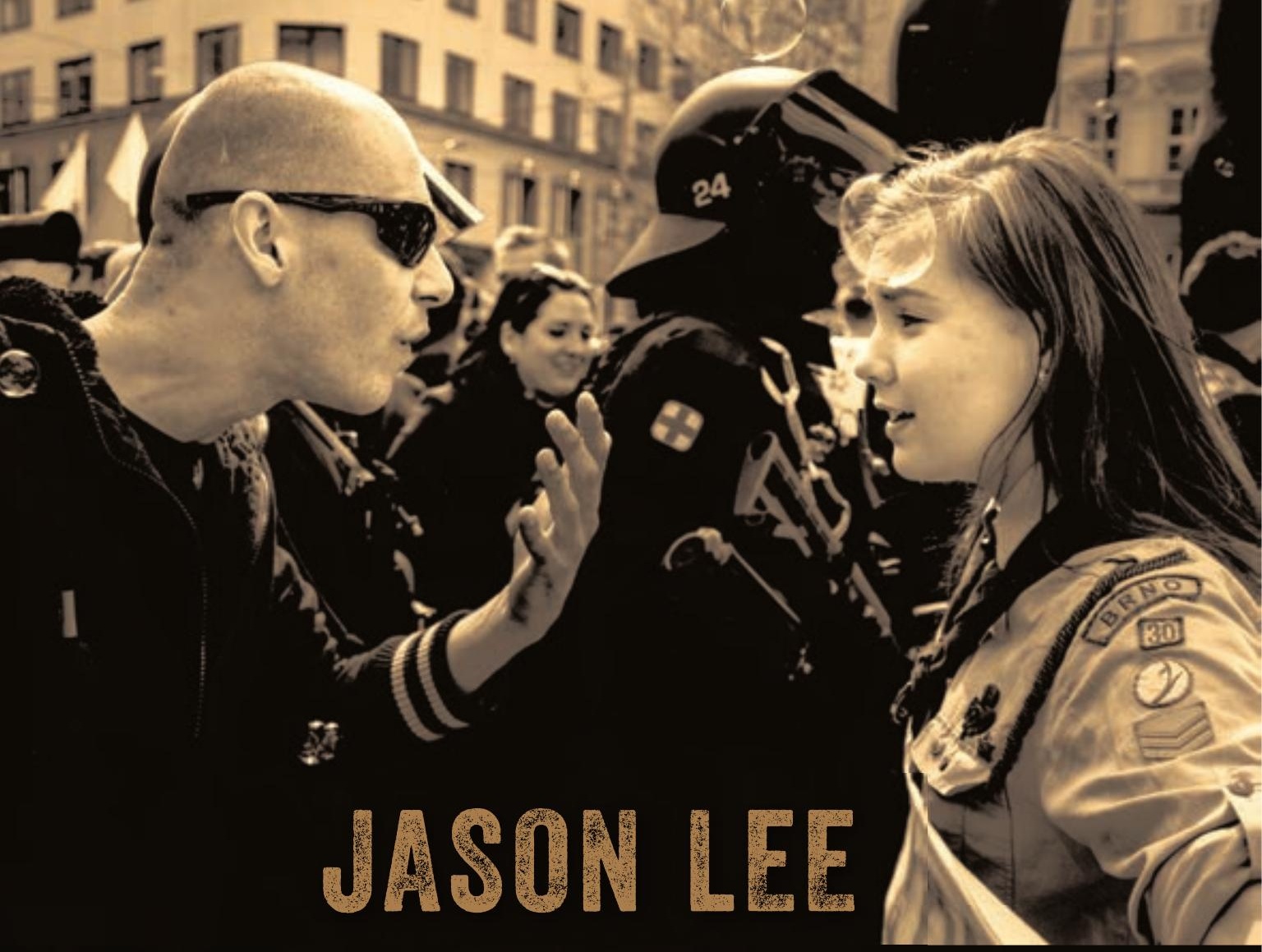

NALISMAND
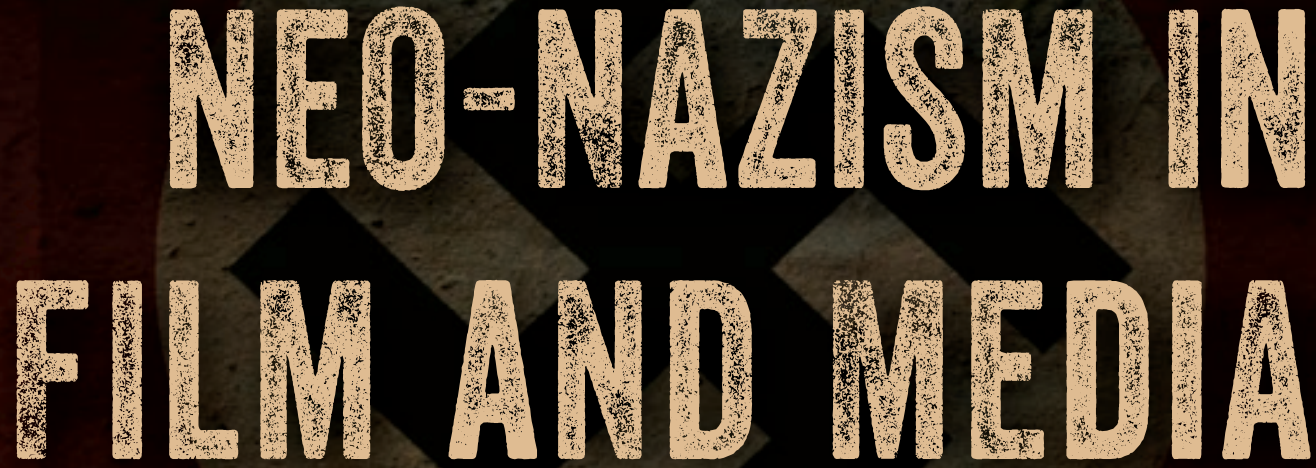

Amsterdam

University

Press 
Nazism and Neo-Nazism in Film and Media 



\section{Nazism and Neo-Nazism in Film and Media}

Jason Lee 
Cover illustration: Girl Scout confronts neo-Nazi at Czech rally. Photo: Vladimir Cicmanec Cover design: Kok Korpershoek, Amsterdam Lay-out: Crius Group, Hulshout

Amsterdam University Press English-language titles are distributed in the US and Canada by the University of Chicago Press.

$\begin{array}{ll}\text { ISBN } & 978 \text { 90 } 89649362 \\ \text { e-ISBN } & 9789048528295 \\ \text { DOI } & 10.5117 / 9789089649362 \\ \text { NUR } & 670\end{array}$

(C) J. Lee / Amsterdam University Press B.V., Amsterdam 2018

All rights reserved. Without limiting the rights under copyright reserved above, no part of this book may be reproduced, stored in or introduced into a retrieval system, or transmitted, in any form or by any means (electronic, mechanical, photocopying, recording or otherwise) without the written permission of both the copyright owner and the author of the book. 


\section{Contents}

1. Introduction - Beliefs, Boundaries, Culture 9

Background and Context $\quad 9$

Football Hooligans $\quad 19$

$\begin{array}{ll}\text { American Separatists } & 25\end{array}$

2. Film and Television 39

Memory and Representation $\quad 39$

$\begin{array}{ll}\text { Childhood and Adolescence } & 60\end{array}$

X-Television $\quad 66$

$\begin{array}{ll}\text { Conclusions } & 71\end{array}$

3. Nazism, Neo-Nazism, and Comedy 75

Conclusions - Comedy and Politics $\quad 85$

4. Necrospectives and Media Transformations $\quad 89$

$\begin{array}{lr}\text { Myth and History } & 89\end{array}$

Until the Next Event 100

$\begin{array}{ll}\text { Trump and the Rise of the Right } & 107\end{array}$

$\begin{array}{ll}\text { Conclusions } & 116\end{array}$

5. Globalization 119

Europe, Asia, Africa, and Latin America $\quad 119$

International Nazi Hunters $\quad 131$

Video Games and Conclusions $\quad 135$

6. Conclusions - The Infinitely Other 141

$\begin{array}{ll}\text { Evil and Violence } & 141\end{array}$

Denial and Memorial $\quad 152$

Europe's New Far Right and Conclusions $\quad 171$

$\begin{array}{ll}\text { Notes } & 189\end{array}$

$\begin{array}{ll}\text { Bibliography } & 193\end{array}$

$\begin{array}{ll}\text { Index } & 199\end{array}$ 



\section{Acknowledgements}

A special thank you to Stuart Price, Chair of the Media Discourse Group at De Montfort University (DMU). Thanks to Heather Savigny (DMU), who was such an encouraging writing partner during the final stages. Many thanks to DMU Global Intern Uche Onyenokporo, who was an excellent research assistant. A particular thank you to Karen Davis at DMU for being so superb in everything she does. Thanks to Andy Collop, Nigel Wright, and Richard Bull at DMU for giving me the space to write. Neil Campbell when I was at Derby was a luminously supportive head of research. I thank my students at a variety of universities, including Essex, Central Lancashire, Hertfordshire and Derby, as well as DMU, for stimulating many of the ideas included in this book. Thanks to David Dabydeen at Warwick for his continued support. Everyone at Amsterdam University Press has been generous and patient, Maryse Elliott particularly so. Thanks to Vladimir Cicmanec.

Foremost, I want to thank my immediate family, Rebecca Griffith, Nathaniel Lee, and Amelia Lee, for their tolerance and intelligence. Nathaniel offered specific insights into video games. With her knowing eyes, Rebecca helped with aspects of the final editing. Many thanks to my father, Charles Terence Lee, for his expertise on Italian media and culture. Thanks to William Goddard for his expertise on football hooligans and Balan Muthurajah for his insight into William Burroughs and for wider discussions. All errors are mine.

The work on racism and Italian culture was presented in the paper 'Italy's Anathematization of the Other: Immigration, Ethnicity and Race in Contemporary Italian Media', The Media in Italy: Historical Perspectives and Future Challenges Conference, The Association of the Study of Modern Italy, Italian Cultural Institute Edinburgh, Stirling Media Research Institute, November 2008. Aspects of this work also appeared in 'Born of Frustration: Folk-devils and Youth Culture in Italian Media', American University of Rome Centre for the Study of Migration and Racism, April 2009. The work on Levinas appeared in 'Levinas, Theory and Practice', presented at the Great Writing Conference, Imperial College, July 2011. Aspects of the section on Death and the Maiden formed part of the paper 'Violence, Difference and Translation in Death and the Maiden', presented at the Global Translation Conference, University of Salford, March 2013. 
Elements of Chapters 4 to 6 were presented as part of the Echoes of Fascism in Contemporary Culture, Politics and Society Conference, Sussex Centre for Cultural Studies, May 2017. I am indebted to the organizers of these conferences. 


\section{Introduction - Beliefs, Boundaries, Culture}

\section{Background and Context}

Despite the killing of over 6 million Jews in the Nazi death camps during World War II, there are still people throughout the world forging identities stemming from Nazi ideology. Recorded incidences of neo-Nazi attacks were increasing even before the rise of Donald Trump, and globally the popularity of neo-Nazi related groups was growing in a variety of forms in different nations. We might conclude with Primo Levi that every age has its own form of fascism. Historical parallels can be identified between the $1930 \mathrm{~s}$ and the 1990 s and beyond, however, this retrospective approach is myopic. Neo-Nazi belief is not limited to one nation or culture. The world and the media appear to be preoccupied over boundaries, with Donald Trump's rhetoric pushing this even further. As Homi Bhabha puts it, 'the boundary is that from which something begins its presencing.' ${ }^{\text {The building of a wall }}$ between America and Mexico has many interpretations, one being it is a form of mask for America in a futile attempt to cling onto its descending identity. Nazism and neo-Nazism are concerned with boundaries, with the media delineating many of these boundaries, even our moral boundaries.

This book concerns Nazism and neo-Nazism and film and media, recognizing media and culture have become fused, taking an approach drawn from cultural and media studies. New media platforms while spreading neo-Nazi ideologies also form part of globalization that in general is construed as a threat to local identity, with the defence being to incorporate Nazi and neoNazi methods. The media continually reworks conceptions of Nazism and neo-Nazism. This book analyses this process and exchange, recognizing the fluidity of the meaning of these key concepts under consideration. This opening chapter offers an overview of media and culture, the second part covering right-wing movements in European football and white separatist movements in America. Neo-Nazism in the context of European football hooliganism is a paradoxical phenomenon where there is evidence of the media driving the violence. Neo-Nazism proliferates through new media technologies but their basic nature is to be anti-organizational. Chapters 2 and 3 deal with film and television and comedy, and with how Nazism and neo-Nazism are mediated through a variety of forms, including the novel and memoir. Issues concerning authenticity, history and theory, the role of new media and technology, the 
importance of the media and neo-Nazism in the era of Donald Trump, and neo-Nazism and globalization are central to Chapters 4 and 5 . The concluding chapter assesses the rise of the new right in Europe.

Our argument concerns demythologizing the reporting of neo-Nazism as a theatre of extremism. Such reporting involves obfuscating the reality that neo-Nazism is often at the centre of media, culture, and society, not its fringes. Despite a reported growth in neo-Nazism, this is not a teleological development. Traversing such a wide range of media, culture and geography can raise methodological questions over the level of analysis, but the depth of this analysis throughout is accessible. While being international in scope this book does not claim to be comprehensive. Scholars such as Gavriel D. Rosenfeld have argued that there has been a gradual normalization of Nazism. There is a historical trajectory concerning images of Adolph Hitler, from the work of Heinrich Hoffman, who documented Hitler's oratorical gestures, to Internet mashups and memes, such as 'Disco Hitler'. Rosenfeld has argued there was a shift at the turn of the millennia away from a moralistic perspective on the Third Reich to a period of normalization. With the chapter in this book on comedy, it should become clear that a comical portrayal of Hitler and Nazism is not linear. But Rosenfeld does raise serious philosophical questions. Normalization of the past means no period is different from any other. This leads to certain assumptions around an abnormal past and a shift towards a desired normal past. ${ }^{2}$ Taking a cultural studies approach, the thesis here is that neo-Nazism has often been at the heart of culture, focusing on Nazism and neo-Nazism in film and media, rather than Hitler's evolution.

Questions about race, racism, neo-Nazism, and identity need to be formulated in the context of the importance of the notions of personal identity being created via imitation. The contemporary media focuses primarily on Islamic terrorism, as with the attacks in London, 22 March 2017, always bracketing events in a framework as a battle with global terrorism. Acts by neo-Nazi white power terrorists, such as the killer of British MP Jo Cox in 2016, are often framed by the media as just the activities of isolated, mentally ill people. By positioning such acts as part of a process where those who may be without a voice express themselves, the media damages perceptions of the mentally ill and misrepresents the facts. Such media framing ignores the international network of neo-Nazi groups that resort to violence and can be termed terrorists. A focus on Islam can be interpreted as legitimizing the escalations of certain wars. This also raises the anti-immigration rhetoric across the world, despite the main attacker in the March 2017 London example being 'made in England', totally born and bred. 
On 22 July 2011, the neo-Nazi Anders Breivik bombed a government building in Oslo, Norway, killing eight people, and shot dead 69 people in Utøya attending a Workers' League youth camp. Breivik had been to the UK, contacting the English Defence League, and maintained he was part of what he termed a war in Europe against immigration, and the spread of Islam in particular. As these events in Norway and elsewhere indicate, there remains in Europe a violent undercurrent of extremist belief. As this book reveals, this is not limited to Europe. This belief system exists in a milieu which has become characterized by violent neo-fascist nationalist rhetoric and an increased propensity for transnational discourse. The Internet has shifted neo-fascist cells from local, parochial operations to an international platform. Breivik's manifesto rapidly became a resource and inspiration to other, disparate, individuals who would otherwise have remained isolated. The neo-fascist racial religion of Wotanism can integrate with the Christian nationalism of Breivik, whilst pro-Aryan groups in Australia exchange intelligence and strategies with esoteric neo-fascists in the United Kingdom. Once repelled by globalized culture(s), the far right has prospered on the back of the technology that facilitates an increased globalism, a subject addressed here. Where fascism may once have been seen as a reaction to modernity, neo-fascism can be read as postmodern extremism: globalized, inchoate, and immersed in incompatible narratives of arguable irrationality. Behind these elements are many paradoxes, but this is also the nature of postmodernism.

People define themselves through both difference and similarity. Our belonging is framed by multiple factors, such as language and land, creating group boundaries and identities. Before we swallow the notion of the ubiquity of heterophobia, meaning all difference is wrong, other evidence needs considering, rather than concluding we are all potential neo-Nazis. What we find is that the acceptance of strangers and an ability to have empathy and be tolerant are just as prevalent in humanity as racism and prejudice. ${ }^{3}$ In this respect, if we concluded incorrectly that racism, especially anti-Semitism, is some kind of human universal, outside of time, this would be legitimizing racism. The history of the far right is not as straightforward or as clear-cut as its opponents might believe. There are overlaps between the Australian One Nation Party, some American groups (such as the American Party), and South African movements nostalgic for apartheid. Areas that have witnessed growing xenophobia in Central and Eastern Europe, such as Latvia's LNNK (For Freedom and Fatherland), and the SRS (Serbian Radical Party), have their origins stemming in independence movements. ${ }^{4}$

Traditional historians are concerned that the understanding of Nazism, particularly by young people, is now gained inaccurately only through 
the media. This suggests history is fixed, certain and unchanging, but the synergy between historical analysis, interpretation and cultural studies is significant. As Hayden White put it, histories are ambiguous, they are 'symbolic structures, extended metaphors', and are situated in narratives we understand from literary culture. ${ }^{5}$ Holocaust survivor and author Elie Wiesel has explained that the problem concerns notion that mass media is profane and may trivialize a sacred subject but it also may inform and educate. ${ }^{6}$ From traditional literature, to films, and multimedia, including videogames, all have utilized Nazi and neo-Nazi elements, and these are discussed here. The frenzy of the visible, as Frederic Jameson called the media age, could be compared to the frenzy of imagery in Nazi culture. These debates are ongoing, and are becoming more high profile in the Donald Trump era, but have never disappeared.

Media and culture have become intertwined, infiltrating into the daily discourse of most people in the modern world, shaping identities. This is a broad area with regards to film representations, from the traditional adaptation of Shakespeare's Richard III (Richard Loncraine, 1995), to a controversial comedy set in a concentration camp, Life Is Beautiful (Roberto Benigni, 1997). History is frequently reworked in film representations, often functioning as secondary and sometimes primary source of information about historical periods. Films such as The Reader (Stephen Daldry, 2008) have placed debates concerning Nazism and neo-Nazism at the centre of the media and cultural discourse. Along with this, the resurgence of support for real fascist movements is disturbing, and needs analysis. With reference to thinkers such as Hannah Arendt, a refugee from Nazi Germany, and Lithuanian-born Emmanuel Levinas, what does the legacy of the past indicate about the future?

Many films, such as American History X (Tony Kaye, 1998), This Is England (Shane Meadows, 2008), and I.D. (Philip Davis, 1995), have powerfully shown the growth in far-right movements and their influence over youth culture. Numerous films have tackled Nazism, including Mephisto (István Szabó, 1981), Das Boot (Wolfgang Petersen, 1981), and Heimat (Edgar Reitz, 1994). The Reader, staring Kate Winslet, and Valkyrie (Bryan Singer, 2008), starring Tom Cruise, received immense media attention between 2008 and 2009 . Winslet, who gained an Academy Award for this role, plays an ex-Nazi guard, while Cruise's character plots the death of Hitler. As with taking on the role of a disabled person, playing a Nazi appears to be an essential challenge for actors proving their worth. There have been a number of important films, such as: The Boy in the Striped Pyjamas (Mark Herman, 2008), The Counterfeiters (Stefan Ruzowitzky, 2007), The Pianist (Roman 
Polanski, 2002), Downfall (Oliver Hirschbiegel, 2004), and Sophie's Choice (Alan J. Pakula, 1982).

Other films, particularly of the horror genre, have Nazism as a backstory where, for example, the children of those experimented upon in Nazi camps gain supernatural powers. Like child sexual abuse, Nazism becomes a device for encapsulating absolute evil, but this is more than a simplistic plot device. This movement through transgressive trauma is presented as giving both the victim and perpetrator abilities, and is part of a theological paradigm. Through enduring the greatest of evils comes the granting of the highest form of grace and if forgiveness is granted this bestowing of grace is even true for those conducting the evil. ${ }^{7}$ Further victimization can occur if there is 'unproblematic identification', as Dominick LaCapra calls it. ${ }^{8}$ This book does not claim to be comprehensive in examining film and television but Chapter 2 explores important examples. There are countless films that use Nazi and neo-Nazi culture in interesting, but less direct ways, including the Raiders of the Lost Ark (Steven Spielberg, 1981). In American Beauty (Sam Mendes, 1999), for example, Colonel Fitts (Chris Cooper) is a repressed homosexual who beats his son. The fact he collects Nazi memorabilia, which again has a comic aspect to it, is supposed to reveal his unstable character. Steven Spielberg's Schindler's List (1993) was based on Thomas Keneally's 1982 novel Schindler's Ark. This is a fictional reworking of a true story and the film managed to put Nazi history back on the agenda for people of all ages, indicating the importance of the relationship between history and film. Chapter 2 explores film and television with regards to memory, authenticity and representation.

The Holocaust might not be thought to be comedic, although it has been used successful as a context for comedy, offering a poignant juxtaposition. Aspect of this are discussed in Chapter 3. If comedy and religion went together, rather than supposedly being antithetical, then Judaism would be held up as the religion that has produced the most well-known and successful comics. Not only do we have the prolific comedian, actor, writer and director Woody Allen but numerous contemporary comedians, such as Adam Sandler. Mel Brooks' The Producers (1968), which concerns the musical Springtime for Hitler, is just one example of the apparently incongruous blending of Nazism and comedy. His film To Be or Not to Be, which led to the infamous 'Hitler Rap' (1983), showed just how influential Brooks' comedy was, with The Producers going on to be adapted as a musical, winning more Tony Awards than any other musical in Broadway history.

The comedy Life Is Beautiful (Roberto Benigni, 1999) concerns a Jewish Italian man Guido Orefice (Roberto Benigni) who uses comedy with his son 
in a concentration camp. It was winner of the Grand Jury Prize at Cannes in 1998, plus the 1998 Academy Awards for best music, score, foreign language film, and actor. While some may have found the film offensive, it movingly raises deep philosophical questions concerning humanity, survival, family, ethics and God. This subject of Nazism, neo-Nazism, and comedy is the focus of Chapter 3; does such comedy serve a useful political purpose, such as bringing about a form of equality, if only momentarily? Aspects of Nazi culture that have been used frequently in television comedy, such as the classic 'don't mention the war' sketch in Fawlty Towers, are also examined. Issues concerning taste, ethics, transgression, the unmasking of authority and the purpose of comedy and laughter are tackled.

Another aim of this text is to take a moderate transnational approach, with examples drawn from mainland Europe, the UK, North and Latin America, Asia, Africa, and beyond. This approach fits with the dominance of multimedia global formats, but there is no claim that this approach is comprehensive. Contemporary re-workings of Nazism and the neo-Nazi use of media have transnational elements that deserve this approach. Along with the explicit need to examine Nazism and neo-Nazism in contemporary media, this book engages with philosophical trends. These themes include what we currently understand to be knowledge, history, memory, meaning, and truth. This is why a number of philosophers are employed here, including Henri Bergson, Jacques Derrida, Julia Kristeva, Jean Baudrillard, Gilles Deleuze, Emmanuel Levinas, and others, such as Hannah Arendt. Arendt came to understand the horror of totalitarianism as not having an explanation stemming from psychopathology but from the servility of its agents, 'the real basis of its truly abject status'. ${ }^{9}$ The core concern is how Nazism and neo-Nazism have been mediated and refashioned since the 1980 s in media. A crucial aspect of this book therefore concerns the construction of truth.

Ironic and non-ironic terms, such as 'Nazi chic', 'Nazi camp' (referring to gay culture and Holocaust glamour) are now ubiquitous. Nazism and neo-Nazism is continually being mediated. The novel The Kindly Ones by Jonathan Littell (2006), for example, created a media sensation, selling 700,000 copies in France alone by 2007. Taking the viewpoint of an SS officer, the novel asks: Would we have behaved differently and could everyone be a Nazi under certain circumstances? Littell further inflamed media debates, when in an interview with Israeli newspaper Haaretz in May 2008 he accused Israel of using the Holocaust politically. He likened Israel's behaviour to that of the Nazis in the build up to World War II. Sociologist Danny Beusch has examined gay Nazi fetishism in online groups by interviewing certain members. He concludes that these groups offer tangible benefits 
for exploring non-normative desires and greater experimentation. This is not framed as a 'queerized' utopian world given the hierarchical elements, including exclusion, reinforcing heteronormative masculinity via (over) conformity. For Beusch, this is not about contesting the signifiers of Nazi regalia, as some queer theorists maintain, but re-asserts the horrific history. ${ }^{10}$ There are many assumptions that still need to be addressed if we conclude this apparently transgressive behaviour is subversive. Further research is required into the constructed gendered and sexual identities and politics of practitioners, as well as the ways through which, 'they frame, experience and understand their embodied sexual practice.".

While anti-Semitism is well known, and popularized in the press and elsewhere, aspects of philo-Semitism are less discussed. Aspects of Jewish culture are in the public consciousness due to the media and celebrity culture, with the likes of singer Madonna and soccer star David Beckham being involved in Jewish mysticism, and over 50 serious books on the Kabala currently available. We also have revenge narrative films, such as Inglorious Basterds (Quentin Tarantino, 2009), starring Brad Pitt as Nazi hunter Aldo Raine, where the divide between elite and popular culture has been crossed. Despite the Left being continually accused of anti-Semitism, in post-1968 France intellectuals fell in love with Judaism. On 21 December 1984 Libération published an influential article on the way intellectuals of the left of the 1970s and 1980 s had made the flight from 'Mao to Moses'. There were numerous examples, not least Jacques Derrida himself, who, along with Noam Chomsky, became an academic celebrity. Importantly, given the wider philosophical issues of this book, Derrida has been blamed for the disappearance of truth.

Highly charged debates concerning Nazism and hoaxes have made it into mainstream media and popular culture, influencing the discourse. In April 1989, German newspaper Stern published what became known as the 'Hitler Diaries'. Celebrated historians verified their authenticity, despite not seeing the documents, and then they were found to be forgeries with the forgers receiving 42 months in prison. What does such a hoax reveal about the desire for 'truth' and the demands of journalism? How can 'experts' be so easily misled, and what does this say about historians? How do such hoaxes damage the writing of 'real' Nazi and Jewish history? And how does this feed into the conspiracy theories of neo-Nazis?

In 1995 Binjamin Wilkomirski published Fragments: Memories of a Wartime Childhood, 1939-1948. ${ }^{12}$ The author claimed to have been in two Nazi concentration camps, and to have been experimented upon for medical purposes by the Nazis. Praised, feted, and compared to Anne Frank and 
Primo Levi by numerous critics, receiving the National Jewish Book Award in the US, the Jewish Quarterly Literature Prize in the UK, and the Prix Memoire de la Shoa in France. But in 2000 it was definitively proven that this book was a hoax. As with child sexual abuse 'testimony' texts, the debates surrounding this book reflected wider issues beyond Nazism and the Holocaust, such as how autobiography, memoir, and 'trauma literature' is perceived, and used by many and developed as part of 'history'.

From politicians to royalty, Nazism and neo-Nazism inflames the media. On 24 February 2006, the BBC reported Ken Livingstone, Mayor of London from 1981 to 1986 and again from 2000 to 2008 , was to be suspended from office for one month for comparing a Jewish journalist to a Nazi concentration camp guard. He was then suspended from the Labour Party after an interview in April 2016 with the BBC when he apparently claimed Hitler was a supporter of Zionism in 1932 with the policy all Jews should be moved to Israel. Livingstone argued he was being attacked by the right-wing of the Labour Party over his support for Palestinian human rights and claimed he had never equated the Israeli government with the Nazis. With the UK's right-wing press dominating the media, highlighting divisions in the opposition party was essential for the ruling Conservatives to deflect criticism. The British tabloid media frequently mocks figures in the public eye and anything involving a celebrity connected to Nazism and neo-Nazism will make the news. In January 2005 Clarence House, speaking on behalf of the British royal family, made an apology in the British media over Prince Harry wearing a Nazi armband to a fancy-dress party.

There is a long history in pop culture of Nazi imagery being employed, with diverse celebrity superstars, such as Michael Jackson and David Bowie using fascist iconography in their acts. In April 2007 Bryan Ferry, former lead singer with Roxy Music, apologized in the media for praising Nazi iconography, having called their imagery 'amazing'. In March 2008 UK sensationalist (now defunct) newspaper The News of the World revealed it possessed video footage of Max Mosley, head of Formula One Racing and son of British wartime fascist leader and Nazi sympathiser Oswald Mosley, 'romping' at a 'Nazi orgy'. Mosley, a former barrister, won a legal case against the paper for invasion of privacy in July 2008. As with the hoax cases, this raised wider issues beyond Nazism and the Holocaust, given this became a debate about what an individual should, or should not, be allowed to do in private. Mr Justice Eady, the presiding judge, claimed Holocaust victims were not being mocked in this instance. In February 2009, Irish rockers U2 in their video to 'Get on Your Boots' overtly utilized Nazi and fascist iconography, with supposed postmodern intent. A number of popes have 
negotiated Nazism in the media. Pope Benedict XVI, a former member of Hitler Youth, was attacked in parts of the media for not doing enough to heal the effects of Nazism. In 2010, prior to a trip to the UK, he claimed the Roman Catholic Church did more to help Jews than is commonly recognized, a controversial statement without historical backing or credibility.

Media images construct the myths we live by and often possess a value higher than truth. The desire for truth has not vanished, even if it seems to be harder to attain. Issues over Nazism and racism have continually made headlines, globally. US extremist groups have been linked to the British National Party (BNP). The transnational scope of neo-Nazism is well-founded and as an example is relevant due to its complexity. The BNP has parts of its origins in Britain's far-right National Front Party, and gained two seats in the European Parliament in July 2009. Questions over censorship and free speech arise in this context. In November 2007, the Oxford University Students Union invited BNP leader Nick Griffin to their 'Free Speech Forum', along with controversial historian and 'Holocaust denier', David Irving. Anti-fascist groups and the Oxford Jewish Society all protested loudly, alongside free speech groups, the resulting clash making international news.

Controversy was sparked again when the BBC's premiere political debate programme Question Time included Griffin as a guest. The event itself became newsworthy, with protests in 2009 outside the BBC preventing staff from leaving the building. The $\mathrm{BBC}$ was accused of conducting a publicity stunt to chase ratings, but even those within Griffin's party concluded his appearance on the show damaged the BNP's reputation. The use of the media to address issues connected to neo-Nazism functioned to damage supporters of certain nationalist white separatist ideologies. Overall, it would be naïve to see this period as some form of decline in nationalism and related neo-Nazism. Since this period, BNP popularity slumped further but members have been joining the right-wing English Defence League, which has stronger links with neo-Nazism. In England, the United Kingdom Independence Party is in many areas the third party, beating the Liberal Democrats. During 2017 fascism was on the rise in Hungary, and former BNP leader Nick Griffin left the UK for the Hungary, a joke in the media being that he too would now become an immigrant.

On 13 February 2009, the BBC News Channel reported that anti-Semitic attacks in England during a four-week period, that included the Israeli attacks on Gaza, were up to 250, compared to only 27 in the previous year, for the same period. In Europe, perhaps the most dramatic moment in the rise of the far right since the turn of the century came in the French presidential 
elections of 2002, with Jean-Marie Le Pen, the leader of the neo-fascist Front National, emerging as the runner-up with 5.5 million votes. His daughter, Marine Le Pen, is now president of Front National, which is the third-largest party in France. Following the terrorist attack on London in March 2017, Marine Le Pen immediately used this as evidence to support her policies.

Right-wing parties have made substantial gains all over Europe. This support may have once seemed unimaginable, given the stigma and revulsion against fascism, extreme nationalism, and racism in the post-war period, but it is now clear that many of the beliefs held dear to the Nazis have not vanished. Russia and all the Eastern European countries have growing, extreme right parties, which are ultra-nationalist, anti-Semitic, and opposed to liberal democracies. In the first three months of 2009 neo-Nazis killed 41 people in Russia. The re-emergence of openly racist parties has complex causes, the degree and form of their racism and its blend with various types of nationalism and regionalism varying between the different countries.

Despite Donald's Trump's rhetoric while attempting to get elected, his own ideology is difficult to pin down, which was part of his effectiveness. The role and power of the media is also highly complex, hence the importance of the analysis in Chapter 5. All the extreme right parties profess a commitment to one or other version of the 'new racism', with an emphasis on nation and culture, with biological versions of 'race' forming perennial subtexts. The immediate catalyst of the success of the revived extreme right in Europe was the mobilization of insecurity and disaffection stemming from the supposed threats to the nation, and its identity and prosperity, posed by immigrants from war-stricken regions.

The Italian media is of particular interest in this context. In Italy, the 'Roms', the Gypsy community, have taken the brunt of racist attacks, and there are direct comparisons in the way Jewish people were depicted in 1930s Germany and the way certain Gypsies are portrayed today in the Italian media. Hitler, writing in Mein Kampf (1933), spoke of the Jew in terms of the vampire, one who waits, strikes, and sullies the living 'pure blood'. Similar language is found today in Italian media regarding the Gypsy community. The world economic crisis has added a further dimension, stirring a desire to restrict all forms of immigration throughout Europe, and this is an ongoing issue elsewhere, including America and Australia. In America, the rise of Donald Trump has also been primarily based around the theme of immigration. On both sides of the Atlantic politicians have been caught up in the anti-Semitism debate.

In the UK, with the ruling Conservative government facing strikes from doctors for the first time in history in 2016, the discovery of huge off-shore 
tax avoidance schemes, multiple election fraud scandals, and a plethora of repeated paedophile scandals with high-profile figures, including politicians, the right-wing press in 2016 focused on anti-Semitism within the opposition Labour party, not for the first time. This was a tactical move by the right wing, and many Jews pointed out that questioning Israel's position towards Palestine is not actually anti-Semitism. Labelling someone a neoNazi is an obvious tactic in political debates, and both sides have done so.

In America, Trump has called for Muslims to be banned from entering America, but his rhetoric on immigration and race regarding Mexicans has meant other extremists have used him as their front man. What is unusual about America is that it is so clearly the country of immigration, and has prided itself in the past on this. One white supremacist with his own radio show, David Duke, a former Klu Klux Klan leader, has made a number of remarks considered to be anti-Semitic, even neo-Nazi. In 2016, the AntiDefamation League called on Donald Trump to respond to Duke's remarks, given the latter was a follower of Trump. After Trump had taken a long time in finally distancing himself from Duke, he did eventually condemn Duke's rhetoric, claiming there was no place for anti-Semitism in America, and his mission was to unite America. Concurrently, he was using anti-immigration rhetoric to whip up commitment from primarily white working-class supporters. During Donald Trump's first press conference as president elect he accused the security services in America of hounding him, Nazi fashion.

Duke's criticism of Jewish behaviour is complex, as he has condemned the way some Jewish backers in the elections were focusing on the support for Israel, calling this anti-American. On his radio show he claimed that Jewish supremacists controlled America, and they were the real problem and the reason America was not great. Trump claimed that he has familial ties to the Jewish community, with his son-in-law Jared Kushner being an Orthodox Jew, and his daughter Ivanka converting to Judaism. Anti-Semitism is at the heart of white power in America, with neo-Nazism driving the discourse. The development of neo-Nazism via the media within European football culture indicates how the media generated neo-Nazi stories around violence. An overview of this process offers an insight into how neo-Nazi stories are generated by the media.

\section{Football Hooligans}

The category football hooligan is contentious, as is the grouping neoNazism. The use of any form of 'ism' needs to contain some form of a warning 
regarding how this term encourages generalization, removing critical clarity and historical awareness. ${ }^{13}$ Neo-Nazism is not something we can easily pin down if we want to maintain historical specificity but there are general patterns that can be identified. When we consider the development of neo-Nazi belief systems it is important to consider how they are organized via gangs and movements in this context. During the 1970s in Britain, the National Front (NF) capitalized on football hooliganism. Britain gained a global reputation for its football violence, which is now emulated elsewhere, such as Russia. There was kudos to be gained by these gangs of hooligans to be regarded as the most extreme, given this meant they were theoretically the most violent and to be feared. Globally, it appears that being the most racist, and the most famous for being the most racist, is an aim of numerous related white power groups.

Despite the National Socialist name suggesting a level of altruism via socialism, the intensely competitive nature of these groups reveals a dehumanizing process. In her analysis of totalitarianism Hannah Arendt concluded that the Nazi death camps resulted from complicity due to people just being a cog in the system, removing their own responsibility. Not everyone who took part in the Nazi death camps was positively complicit, with some committing suicide, some ending up with extreme psychological disorders. ${ }^{14}$ When voting for Hitler the German people were not complicit with future genocide, but did not resist this when it happened. The level of extremism and activities that follow on from this extremism varies, but this trait of competition and game playing in subcultures is a significant cultural phenomenon.

Utilizing various methods of media has been central to the dissemination of neo-Nazi ideas in this context. The National Front (NF) youth magazine, Bulldog, was sold at many football grounds openly, as well as distributed in schools across the UK throughout the 1970s and 1980s. At a time of mass unemployment and social unrest, the NF appealed to young people, feeding on a sense of teenage alienation, hatred and rebellion, offering a sense of identity and a focus for mass discontent. Racial hatred was a channel for deeper levels of hatred, stemming in many cases from social inequality, but this is not the total explanation. As with the Nazi party originally, the NF wanted to 'send them back', with the desire to rid the nation of black or Asian people. What the history of racism shows is the shifting levels of acceptance, given at periods of times Jews, the Irish, and Italians have also been considered like Africans, subhuman. ${ }^{5}$

Masquerading as a party with some semblance of common sense and traditional values, through policies such as bringing back hanging and 
protecting the green belt, the National Front believed all non-whites should be repatriated and removed from Britain. Outside of the National Front, earlier politicians, such as the Conservative MP Enoch Powell, well known for his 'Rivers of Blood' speech, delivered to a Conservative Association meeting in Birmingham on 20 April 1968, had promoted such policies. In this sense, the NF was not at the fringes of political discourse. A central argument of this book overall is neo-Nazism is not at the margins. The UK's NF fits the thesis of this book concerning neo-Nazism actually being within the mainstream. The Union Jack flag waving and skinhead culture was innately part of the NF, indicating how tribalism was key.

In the UK, West Ham, Chelsea, Leeds United, and Millwall were all clubs where NF symbols were adapted within merchandise to promote the political movement as part of a football supporter's way of life. ${ }^{16}$ Badges and symbols have always been part of football fandom and part of Nazi culture. Neo-Nazism carried this forward in the context of football support in various forms. There was a culture that held at its centre that a certain element of society was now being threatened. This element was perceived to be the white working or middle-class male. Hatred can have many outlets and the hatred of the other 'tribe', such as the adjacent club in the same city, can overlap with racial hatred. Celtic and Rangers in Scotland have a long-lasting religious competition that feeds into wider rivalries.

Groups and distinct parties that formed from the NF went on to some success politically, one of them being the British National Party (BNP). Their leaflets were apparently found at the stadium after the Heysel tragedy in 1985, where a collapsed wall left 39 people dead. During the 1995 match between England and the Republic of Ireland at Landsdowne Road, Dublin, it is claimed the National Socialist Alliance organized fights and incidents that led to the game being stopped after half an hour, and the BNP and Combat 18 were also both thought to be involved. ${ }^{17}$ In 1993 in the UK the Campaign for Racial Equality launched the 'Let's Kick Racism Out of Football' campaign. While the fragmentary nature of groups makes it difficult for them to carry out organized activities, it also makes them difficult to analyse, and limits preventing their activities. This has parallels with neo-Nazi groups across Europe, and with Islamic extremism, with the fragmentary network approach allowing for more invisibility. The emphasis on fans might obfuscate institutional racism in football. In August 2017 it emerged that in women's football England striker Eniola Aluko, who has 102 England caps and is a lawyer, claimed Mark Sampson, who had led England to the semi-finals of the European Championships, had made 
racist comments. Aluko had already received $£ 80,000$ from the Football Association after a bullying and harassment case.

After the Heysel tragedy, the University of Leuven in Belgium published work in 1987 that tracked right-wing fans at home and abroad. Suggestions that there was an organized network of neo-Nazi supporters have been questioned and doubted, but there is tangential evidence of a process of grooming and leadership by older, more experienced fans. Old and new media are involved. The exchange of letters between young supporters and more seasoned fans is not strong evidence of an organized network at this period. This was a period before the Internet, meaning relationships between neo-Nazi fans could not be strengthened online, but simultaneously they would be less likely to be traced and the strength of relationships could be overlooked.

Extreme right-wing groups connected to a number of Italian clubs, including Bergano, Brescia, Milan and Verano, utilized Nazi symbols, with this also being the case across Europe, especially in Spain, Germany, Switzerland, the Netherlands, Austria and France. ${ }^{18}$ In continental Europe, the most well-known teams with neo-Nazi affiliations are Lazio, AC Milan, Paris Saint-Germaine, and Real Madrid and Espagnole. In 2016, the media debates in Italy concerned the future of Italian football and whether away fans should be allowed to travel to matches, especially following violence between Atlanta and Roma. The excessive security in some grounds means some Ultras refuse to go to stadiums. The issue concerns whether Ultras should be criminalized but an overall conclusion from the police and football organizations is that particular football fans should not be excluded, given this can isolate and possibly escalate violence.

The media's focus during the 198 os on the English fans has led to them being emulated abroad, especially by Russian fans linked to neo-Nazi ideologies. The period itself is often interpreted as a highpoint of hooliganism, so among fans that appreciate this form of hooliganism there is a nostalgic yearning and reification of the period. Of course, structurally, the organizing of football matches during the main non-work days of the week can also be interpreted sociologically as one way of controlling workers, and preventing rioting and violence on the streets. Allowing for a frenzy of controlled real or simulated violence, and offering this in stadiums functions as a form of theatre, and offers a form of transgression that can allow the reassertion of the law.

Racism has been at the core of the violence. If it was Italian and English fans that had the reputation for being the most violent and right-wing in the 1980s, Russian fans, some known as right-wing Ultras, more recently 
gained this reputation. They were deliberately escalating violence in 2016 against English and Welsh fans. Footage of Russian fans, moving in to attack English fans peacefully drinking in bars in France, causing severe injury, offers the evidence that this was organized violence of a scale that had not been seen since the 1980 os. Political tensions were high in 2016, Russia having recently annexed the Crimea from the Ukraine, and President Putin taking an antagonistic stance against the West.

The British press claimed that Russia reported these attacks as a form of victory for the glorious Russians, but it needs to be noted that outlets such as Russia Today focused quite objectively on the violence. One nation's media attacking another nation's media is a way of generating news that concerns misinterpretations of falsities, leading us further away from the story and the truth. The role of the media is of significance, given it was reported that in Mexico in 1980 os British newspaper reporters were offering money to English fans to 'smash up hotels', and then offering money to bail out fans once they had been arrested. ${ }^{19}$

Sociologists have considered the causes of the racism on the terraces, but some take a simplistic approach tied to the past when income levels for players and fans were lower. Some condemned fans as being uneducated, coming from low-income sectors, or being 'witless', tying racism to sexism and white men in general. ${ }^{20}$ This denies the level of wealth generated by the game, including the wealth of the fans. Others, especially psychologists, have attempted to deal with racism on the terraces by stressing improvements in the conditions for the fans and involving them in the running of the clubs by promoting the links between clubs and the heritage of the community. In May 1989, there were 220 arrests at football matches in one weekend, one month after Hillsborough, leading some academics to swallow the story of the police and the press that the tragedy of Hillsborough had been caused by evil fans. ${ }^{21}$ In the UK, the government struggled to know how to deal with hooliganism post-Hillsborough, without the later revelation that all the blame put on the fans was invented.

A number of 'firms', like the Chelsea Head Hunters, have been linked to racist groups, such as Combat 18 and the National Front, and even with paramilitary groups, such as the Ulster Defence Association. These groups have been popularized in fiction, such as The Football Factory by John King, first published in 1996 and released as a film in 2004 directed by Nick Love. The back-cover blurb from the Glasgow Herald claims it is, 'a chronicle of a lost tribe - the white, Anglo-Saxon, heterosexual who is fed up with being told he is crap'. ${ }^{22}$ Whiteness is constructed as an absent centre, and within European history this stems from a denial of imperialism. It is assumed 
in European culture to be without definition, boundary, and formed from comparisons between itself and others. ${ }^{23}$ Jason Marriner, a former leader of the Headhunters, claimed that the $\mathrm{BBC}$ set him up, depicting him as a racist neo-Nazi with wider connections. According to Marriner on his website and in various documentaries, convictions happened without corroborating footage. Fiction has blurred with reality, with Marriner and Danny Dyer, the lead role in the fiction film The Football Factory (Nick Love, 2004), touring the country as 'The Real Football Factory'.

The Headhunters have not disappeared, and were involved in disturbances in Paris before a UEFA Champions League quarter final between Paris Saint-Germain and Chelsea on 2 April 2014. Around 300 hooligans were involved in pre-planned violence around the city, with hardcore hooligans having avoided police detection by entering France via Belgium. The National Front is still active, with David MacDonald, the leader of the organization, winning a seat on Aberdeen's Garthdee community council, after securing eighteen votes. The fact that this small success was news indicates that the NF is not a significant party in and of itself, but we can see its main tenets have shifted even further into the mainstream with UKIP. MacDonald apparently left the British National Party because he did not believe it was right wing enough. Drawing on Judith Duffy's report on 31 January 2017 in The Herald, the world media, including Reuters and Russia Today, reported that the NF had started a recruitment campaign, distributing Bulldog outside schools in Aberdeen. Thankfully, they had received 'disappointing' feedback, most young people, according to MacDonald, were not interested.

The NF were going to do the same in Glasgow and Dundee, and head teachers took action, forewarning parents, with the NF only approaching those aged sixteen and above. The Aberdeen Anti-Fascist Alliance branded this as a throwback to the 1970s, claiming the NF was an 'embarrassment', with no real support. The publication Bulldog, aimed at a youth audience, was re-launched in 2015. Interestingly, the NF's tactics of trying to engage with 'disaffected' youth can be paralleled with the tactics employed by Islamic State (IS), in their radicalization of young people. In the mid-199os jihadi groups were permitted to distribute literature openly, in public areas such as outside shopping centres in major cities like Manchester. By 2016 if IS was to carry out similar activities, such as this by the NF, it would generate even more protest, and police action.

The nostalgia for the 1970 s is a theme that unites many football hooligans and the neo-Nazi right, and the outward face of right-wing politics like UKIP, with neo-Nazi groups throughout the world believing the present is tainted. 
Leicester, the home of 2016 Premiere League champions Leicester City FC, has been regarded as the most multicultural city in England. But in the 1976 UK local elections, the NF gained 20 per cent of the vote in Leicester's local elections, fielding 48 candidates, this being their high point. In April 2013, the NF intended to field 35 candidates in local elections nationally, their highest number for 30 years. One of their original policies was to leave the European Community; hence the EU referendum of June 2016 resurrected interest in the party.

During the 1970s the NF attempted an international agenda, through working with commonwealth countries, including establishing the New Zealand National Front, South African National Front, and National Front of Australia, finding it harder in Canada to formalize an NF sister organization. The gains of UKIP need to be looked at via the lens of the demise of various forms of the NF. Many examples can be given, such as councillor Victoria Ayling, who allegedly attended NF rallies, and who is recorded as stating her basic policy is to 'send people back', a central NF tenant. The mainstream British media, such as The Sun, has attempted to condemn movements like the NF and Britain First, separating them out from UKIP, and even the BNP. An examination of their beliefs and membership often makes such differentiation difficult to establish.

Members of the banned neo-Nazi group Combat 18, certain followers of the English Defence League, plus different members of the British National Party, are all part of this melting pot of fascism, with party allegiances not being as important as they once were. An 'ism' might be generic and non-historical, but it is undeniable that there are overlaps between these various groups. Britain First has received the greatest amount of media attention, given its controversial and confrontational style and its use of social media. Staging events, such as bursting into Muslim-owned shops and declaring the owners to be supporting terrorism, and then posting this on Facebook is one tactic. Overall, it is pointless calculating the level of virtual or real followers from this activity, given the number of views can be manipulated, as can the number of followers. What can be concluded is that support for Britain to leave the EU united followers of all these fragmented groups behind a single cause.

\section{American Separatists}

Levels of violence in America are notably higher when we consider neo-Nazi subcultures in an American context. On 25 June 2016, for example, a mass 
stabbing took place at a neo-Nazi rally in Sacramento, California. Numbers vary, with estimates that 40 people took part in white power protest and were confronted with 400 in a counter-demonstration. There was believed to be nine men and one woman stabbed, ages ranging from 19 to $5^{8}$ years old. The Southern Poverty Law Center, with a global reputation for investigating American extremist groups, maintained that the rally was held by a white nationalist extremist group, the Traditionalist Worker Party. They had called the demonstration to protest against the anti-Trump violence that had broken out at rallies held for Donald Trump. This presidential candidate's inflammatory anti-immigrant rhetoric had been part of the discourse that is centred on threats and violence. As with this, counterdemonstrations globally against anti-Nazis are often more supported than those by any groups with neo-Nazi sympathies. The violence at various Trump rallies appears to have been committed by white nationalists, with there being clear footage of the party's chairman, Matthew Heimbach, attacking a woman at a Trump rally. Online support came from the Golden State Skinheads.

This followed on from four people being stabbed at a Klu Klux Klan rally in Anaheim, California. With Trump taking an anti-ethnic stance from his platform, along with Nigel Farage, leader of the United Kingdom Independence Party (UKIP), stirring up hatred towards immigrants in the UK during the EU referendum, it is unsurprising that people began to act out their racist beliefs. They were now publicly being legitimized by their leaders. People born in the UK from an ethnic origin began to be on the receiving end of racist abuse. On 29 June 2016 BBC Midlands Today reported Trish Adudu was racially abused in Coventry. Importantly, she was not going to report this to the police, because she was in shock, but through discussing the incident on social media she was persuaded to report it to the police. This reveals another interesting impact of social media, because even those we do not actually know can persuade us to take action. She had not been alone, and had initially witnessed people abusing others. UKIP's leader at the time, Nigel Farage, mistakenly claimed that his Leave the EU campaign had been victorious, 'without firing a single bullet'. This was ignoring the fact that Labour Party politician Jo Cox, who had campaigned for Britain to remain in the EU, had been shot and stabbed to death on 16 June 2016 by a white separatist. It is believed that following the Vote Leave victory in the EU referendum there was an increase in racist violence in the UK. Across Europe the intense hatred of immigrants repeated by the popular press was leading to some very real violent acts that could be interpreted as neo-Nazi behaviour. 
To claim that in America specifically there has been an increase in neo-Nazism does not allow for any nuances concerning the term. The relationship between neo-Nazism and celebrity is significant. One figure in the movement, Craig Cobb, personally has celebrated himself as one of the most famous racists in the world, gaining global media attention. Whether Cobb became such a virulent racist in order to become famous is an interesting question. This overlaps with the notion that Donald Trump only says extremely offensive comments to attract attention. A similar question arises concerning white separatist terrorism activity. In the age of social media, fascist groups globally have seized the opportunity to promote their ideologies and achieve notoriety.

Those who may have remained previously on the fringes of society, within their own subcultures, without access to the wider population, have been given the opportunity to enter the mainstream through social media. People can still operate from the fringes, but shifting ideologies with some core beliefs have become popularized. With the blurring of the private and the public, these ideologies have used these methods to intimidate those who may resist them. Cobb's specific aim has been to take over small towns by purchasing cheap plots of land, then moving fellow white supremacists into towns to create a majority for those supporting his extremist ideology. From these actions, the intention is then to take over town councils and local leadership groups, and gain power.

This behaviour is in tune with that stipulated by the National Alliance (NA), as portrayed by the Southern Poverty Law Center (SPLC). According to the National Alliance website, the aim is to establish new societies based on Aryan values. Explicitly, this dictates what type of culture is allowed. There is even an element of the regimes of Oliver Cromwell and the Taliban about this, which appears ludicrous. For example, specific culture is banned, while other forms are promoted: literally, no Barry Manilow and no art galleries containing Marc Chagall. Basically, no jazz and no rock are permitted, but polkas, waltzes, reels and jigs are allowed. This ignoring of contemporary culture and reifying traditional culture promotes the view that there is a certain 'pure' way of being reaching back to an original past.

In such a community, the outside world becomes a threat, any evil positioned on those who are not part of the inside group, allowing the group to then unite in its hatred of outsiders. The ongoing paradox is that contemporary methods through all forms of new media are employed in an attempt to draw people back to a mythological past, a fantasy nostalgia land devoid of all apparent threat from the other. The same tactics can be seen to be used by the United Kingdom Independent Party (UKIP) and 
its sympathizers and vote leave backers, who hark back nostalgically to a mythic time, that never actually existed, always blaming 'the other' for anything wrong. This shift in the use of new media is significant in the history of allied movements.

When the American Nazi Party (ANP), formed by George Lincoln Rockwell in 1958, began vociferously attacking Jews, it was part of a wider discourse over the rights of black Americans. Conspiracy theories were spread that it was Jews who were encouraging black Americans to rape white women. The high point of Rockwell's success was in the summer of 1966 when for 22 days ANP activists gained huge publicity by disrupting Martin Luther King Jr's desegregation marches in Chicago. Over 1,00o residents attacked the marchers, shouting 'White Power!'24 Then, in an attempt to broaden the appeal of the party, Rockwell changed its name to the National Socialist White People's Party (NSWPP). Rockwell's assassination on 25 August 1967 is still cloaked in a complex mystery surrounding power struggles within his movement, and allegations concerning the Anti-Defamation League (ADL). Elements of this history are relevant today, revealing the way related movements have always carried some public support, even in the mainstream, and how this consistently includes calls for a form of Armageddon. The Book of Revelation in the Bible is the most-written about text in Christianity, and America has consistently been at the cliff face of the apocalypse, according to its propagandists. This promotion of the concept of the end of the world also is situated in the context of cleansing the earth of all that is impure.

The neo-Nazi text The Turner Diaries is a case in point. This apocalyptic novel concerns a race war and, in 1971, years before it was published, its author, William Pierce, called for a revolution via urban warfare and political assassinations. The novel, first published in 1978 under the pseudonym Andrew Macdonald, described a future race war, where Jews and members of other reviled groups are slaughtered. Following a similar pattern to general white supremacist discourse, here the white population is depicted as persecuted and now on the margins, their rights being relinquished. Set in 1991, an underground movement goes to war against 'the System', after the Cohen Act outlaws private gun ownership, with 800,000 people arrested due to this law. Written on the cusp of the invention of the Internet, what is of note concerning the media is firstly how right-wing publishers and websites since, such as Counter Currents, have continued to critically promote the book, and how in the novel the Organization fights against the System by becoming more systematized and organized, and less fluid, as if in the future no new methods of communication exist. 
The author was a scientist and the text is not multilayered, in many ways ignoring much of the more interesting developments in literary style over the twentieth century. This latter interpretation of the text, from a literary criticism and a creative writing perspective, could just indicate a lack of imagination on the part of the author, but from a political perspective it indicates a desire for a more traditional form of society, in every respect. African Americans are dismissed as lazy, a by-product of equality laws, protecting everyone's rights, including the right to do very little, while women's groups are thought to be dominated by Jewish women. There is an overt element of envy towards the Jewish population for their level of success and for feeling so at home in America. With victory at home, they have a total victory globally against the Chinese, and all 'others' resistant to the Organization. This comes in the close of the novel in the penultimate paragraph, through a process of chemical, biological, and radiological warfare over four years, 'sterilizing' 16 million square miles, creating the 'Great Eastern Waste'.

The authoritarian nature of the Organization is obvious, and this is far away from Louise Michel's notion of evil where, in the eyes of the anarchist at least, it is not about certain types of governments but the very idea of government that is evil. For the anarchist, the principle of authority is evil. This is to some degree its antithesis, and the form of this uninteresting novel is revealing, given it follows an authoritarian and traditional structure. For the neo-Nazi, absolute authority is absolute good, with a deification of the leader to the level of a god. The beauty of religion is that authority ultimately remains beyond the human, but once godlike authority is given to men all manner of fascist evils can result. One can almost view this as a post-apocalyptic novel, indicating a desire on the founder of the National Alliance for an absolute destruction of large parts of the world, in the name of white power, worshipping a new order based on Hitler.

Steve Bannon, a political activist, media executive and former Senior Counselor to President Trump, lifted his propaganda straight from this earlier context. After leaving the White House in August 2017, Bannon returned to Breitbart News, the right-wing website he had called the platform for the alt-right. Behind his 2011 film Generation Zero is a form of conspiricism. One main area is the bankers, thought to be Jewish. 'Conspiricism blames individualized and subjective forces for political, economic, and social problems rather than analyzing conflict in terms of systems, institutions, and structures of power. ${ }^{25}$ Pierce's associate Willis Carto in his newspaper Spotlight repeatedly claimed the ills of America and the world were down to international bankers. While Drabble claims support for white power 
movements has declined since the 1970s, many more groups have sprung up, including the Aryan Nations, the White Aryan Resistance, the National Alliance (NA), and the Mountain Church. These all worship Hitler and Rockwell. ${ }^{26}$

There is an overlap here with the American militia movement. The numbers who are members of this movement are difficult to establish, with estimates ranging from 20,000 to 10 million in militias. ${ }^{27}$ These selfdeclared Christian patriots celebrate violence as central to their ideology and believe it to be admirable, which overlaps with elements of Trump's rhetoric at his 2016 rallies. Developing from the ANP, the NA was formed out of the National Youth Alliance that developed out of the Youth for Wallace organization, which backed Governor George Wallace's 1968 presidential campaign, running on a pro-segregationist platform. The NA's Pacific Northwest coordinator broke away to form a terrorist group called The Order (Silent Brotherhood, or Bruders Schwiegen) patterned on The Organization as detailed in The Turner Diaries, arguably the most important piece of extremist literature ever produced in America.

A decade after the main part of the novel The Turner Diaries is set, Pierce died in 2002 and the NA fell apart. A ruling by the Supreme Court of Canada on 9 June 2016 meant the NA did not receive a bequest of $\$ 220,000$ from the estate of Robert McCorkill, which may have been a crucial financial lifeline to resurrect the movement. The court also ordered the Canadian Association for Free Expression (CAFE), which backed the bequest to the NA, to pay the estimated $\$ 9,000$ court costs of those who had tried to halt the bequest. According to Mark Potok of the SPLC, at its peak the NA had 1,400 members, but this was now a few dozen. ${ }^{28}$ In a wider context, Richard Cohen, president of the SPLC, commenting on this case, claimed that the radical right is larger than it has been in years, hence the importance of this case. McCorkill's sister Isabelle was joined by the Centre for Israel and Jewish Affairs and the attorney general of New Brunswick in the action, arguing successfully that allowing this bequest to go to a neo-Nazi group was contrary to both Canadian criminal law and public policy. Interestingly, this would not have happened in America, where freedom of speech and association protections are stronger, with Canadian law having a much fuller sense of the concept of the public good. The group is now battling within itself, and has splintered into the National Alliance Reform and Restoration Group, attempting to remove the directors of the NA, and seize its assets, including the headquarters, a compound based in West Virginia.

Despite a panic over neo-Nazism, often fuelled by the media, infighting seems to prevail for neo-Nazi groups, while its opposition appears to be more 
organized. An antagonistic striving for power and dominance within groups that emphasize survival of the fittest at all costs can only be expected, but this also reflects on how assumptions about an organized network need to be questioned. Cobb's actions re-ignited groups such as Anti-Racist Action to protest against this 'exterminationist' philosophy, where anyone not fitting Cobb's idea of a 'pure' European American should be killed. The resistance to such an ideology is strong and it unites disparate groups. In the American context, this includes the African-American communities, the non-extremist white communities, and the Native American communities. These combined latter groups are in the majority, and believe in equality and rights for all. This in itself has, however, created antagonisms, both in America with the rise of Donald Trump, and in Europe with the popularity of groups who believe the systematic implementation of a human rights agenda is akin to being dictated to. The latter has been one of the main arguments of UKIP.

Associates of Cobb's are members of the National Socialist Movement who, as with the Nazis, often portray themselves as victims who believe they are now in a minority and are persecuted. Within this ideology all systems are dominated by an evil source, normally Zionist in origin. The switching of the victimhood role here is telling, and the extent the media is utilized noteworthy. Throughout all of this activity, Cobb was courting the media, and using the Internet prolifically for nefarious purposes, such as posting the personal details of any neighbour or potential enemy. The revealing of personal details might not appear that problematic, given anyone spending time on the Internet can normally find specific details on most people, if they choose. This was, however, to highlight certain people who could then be perceived as enemies of Cobb's associates within the white power movement, and once you were on his list then you were in danger from a wide range of extremists. More importantly, in this context, it is the extent of this use that is most revealing.

Cobb's use of the Internet is significant, with him spending sometimes 20 hours a day online, this being what can be considered a central weapon of his arsenal. In an age when the Internet dominates, this level of use may not appear strange or extreme but it indicates how this form of technology has absorbed leaders within extremist neo-Nazi movements. The original utopianism concerning much discourse on this technology needs to be more balanced. While it is important to avoid generalizations and clichés, Cobb's claim that he may have some form of Asperger's links to this asocial behaviour, and his obsessive use of computers. He personally promotes the view that his knowledge and use of the Internet is somehow supernatural, and this gives him mystical powers. 
The only way to retaliate was for groups who were demonized by Cobb, including his white neighbours who had never encountered such racist groups before or even knew such groups existed, to similarly engage with complex media and surveillance techniques. In some instances, this was of a professional standard. This included recording all significant activities and movements of known neo-Nazis and self-confessed National Socialists, including events and incidents at town meetings, and any activity that could be conceived as threatening. A central reason to create such tensions, one can only assume, was to drive those antithetical to Cobb's views from the town they called home. The main town that Cobb attempted to seize was Leith in North Dakota which, from a 2010 census, had a population of just sixteen, and theoretically could offer little resistance to an influx of white supremacists. Those who may have moved to Leith to live a quiet unobserved life, outside the mainstream, were now under close and intense scrutiny, and were then driven to utilizing similar observational techniques in their defence.

The clear dream of many of the inhabitants had been to live a life of freedom, sacrificing the benefits of modern life for the benefits of living away from any metropolis. There is no autonomy under observation, so in this remote area residents were now in a prison-like environment, constantly observed, without any freedoms. On top of this, residents believed their children were under threat, as Cobb and his associates used threats and menacing behaviour to intimate people, in what only can be construed as an attempt to encourage people to move. The extent of the dominance from white power followers is debatable, but their overt and blatant promotion of their beliefs cannot be overlooked. In such circumstances, the quality of life of the residents was exponentially diminished. A town of people that, perhaps naively, trusted other people's good intentions was forced into acknowledging any stranger may have an antagonistic purpose, which could be life-threatening to others. What could not have been predicted was how extreme the new neighbours' beliefs were.

At first, local residents thought Cobb was just a lonely eccentric man who was a self-contained introvert. They respected him for this, and then allowed him to become a quiet member of their community without realizing he would go on to threaten them and their children with guns and attempt to establish a white supremacist neo-Nazi community. Interestingly, in some respects Cobb's group had gone even further than the Nazis in their beliefs. These were kept on the fringes of fantasy and the imagination, and not especially acted out in reality, but they did have an international impact, reflecting on the wider attraction and promotion of neo-Nazism through 
a variety of methods. Despite the small-town nature of these activities, as exemplified in the 2015 Netflix documentary Welcome to Leith, which focused on the subject, and predominantly on the character of Cobb, the global reach of this phenomenon, through the media of course, is worth considering. We have already seen how National Socialism in a variety of forms has an international element, especially in areas of Russia, as exemplified by the stated beliefs of certain football fans. Cobb himself became a global media phenomenon, which may have been his original intention, given his desire to be the most famous racist in the world.

At town meetings, where Cobb attempted to gain a majority, and tried to take over governance, the British media, such as Sarah Collins from The Mail Online, were present. Cobb often comes across as mentally ill, or at least pretending to be insane, rushing around the town hall with a lap top, thrusting it into people's faces, in an attempt to intimidate people. The central focus of the global media questioning was over how people were now living in fear, after living an apparently quiet life. The subtext is that this phenomenon can appear from apparently nowhere, and people need to be more vigilant. Some residents had deliberately moved to Leith to perhaps escape and start a new life, such as one man whose daughter had been murdered. Cobb and his associates hounded and threatened these people intensely, using their previous history and new media technology against them. Cobb even appeared on the British chat show Trisha, in front of a mainly black audience with a black host, where the results of his DNA test revealed he is actually 14 per cent African. That such a known racist and hater of black people should be part-African was paradoxical, and Trisha and others on the show found this highly amusing. 'See, you got the black man in you,' was repeated at him with laughter, and Cobb appeared to sense the paradox and the humour in this.

Eventually, Cobb and an associate were charged in November 2013 of three counts of terrorism. After threatening the people of Leith with guns, he was banned for life from holding firearms and from contacting those he had been harassing through any methods. Luckily, the legal system in this case had caught up with the technological age and recognized the use of the Internet for hate crimes. The residents believed that justice was not served and they had been duped, given Cobb offered a plea bargain, apologized, and was released from prison, having served his time waiting for the court case. As soon as he was released, on camera during the making of Welcome to Leith, Cobb stated that they must regret releasing him, given he was still peddling a race hatred ideology, promoting the white power doctrine. Cobb's behaviour may appear eccentric, but it gained him further publicity, and 
it does touch on other forms of racist belief that have been growing rapidly during an age of mass migration, globalization, and the Internet.

Cobb and his associates claimed that it was the white people that were being persecuted and were now in the minority. This is not a particularly uncommon view. For example, in the debates over whether Britain should leave the European Union, it has been claimed that in some schools, especially in urban areas like London, English is not the first language and that white people are in the minority. First the National Front, then the British National Party, and now the United Kingdom Independence Party and English Defence League, all utilized the term 'white flight' to promote the view that places were being 'invaded' by other races and an indigenous way of life was being destroyed. This can lead to the notion that the white race is the victim, ignoring a whole history of racism, colonization, and oppression.

Cobb portrayed himself as a victim, suggesting that his 'weird' behaviour, as he put it, came from his military upbringing and from his mild Asperger's. Not everyone with this type of background becomes a high profile, dangerous neo-Nazi, leading a group of people who maintain all 'others' need to be murdered. According to the Southern Poverty Law Centre there are hundreds of thousands of Americans with these beliefs, part of the Creator movement, believing Aryan men are god, literally worshipping themselves. The political rise of Donald Trump in 2015 can be considered in this context, every racist comment bringing him more support from audiences across America. This, for some like documentary maker and political agitator Michael Moore, is merely the 'last roar of the dinosaurs', but such a view ignores the popularity of Trump, which reveals the ideals of the American dream have not succeeded. What was supposed to be a melting pot has turned into a standoff between so-called whites and so-called 'others'. Since the attack on the Twin Towers on 9/11 the focus of American government funding went to attempting to reduce Islamic extremism, shifting funding away from white extremists, but earlier related incidents need to be briefly considered.

The accusation of child sexual abuse was made against David Koresh, leader of the Branch Davidian sect. An accepted story is that after the FBI killed 76 members of the group, including 27 children, at the culmination of the Waco siege on 19 April 1993. Timothy McVeigh took it into his own hands to seek revenge for these murders, although he claimed personally this was not the cause of his actions. Like Cobb, McVeigh had a military background, but he was viewed also as a war hero. Unlike Cobb, McVeigh denied working with others and claimed personal responsibility for all his actions. ${ }^{29}$ As Gore Vidal has shown, the members of the Davidian Church 
put on trial for 'conspiracy to commit murder' after being attacked by federal agents, were found to be innocent of this charge, but eight innocent people were still sentenced to up to 40 years for lesser charges. Vidal was one of only a few people to try to ascertain exactly why McVeigh carried out the 19 April 1995 bombing of the Alfred P. Murrah Federal Building in Oklahoma City, containing the FBI, which killed 168 people, and injured over 800 . Wild, media-driven discourse attempted to personify McVeigh as the epitome of evil, monstrousness incarnate.

Neo-Nazi material, such as The Turner Diaries, were found in McVeigh's possession, or at least this is the line that was actively promoted by government agencies and the media, desperate to find a cause behind this act. In a letter to Vidal, McVeigh explains his actions were not revenge over Waco at all. The Turner Diaries was more of a sideshow in this narrative, and taken a step further it might be suggested they were planted. Vidal pointed out that McVeigh's obsession was with the militia and with guns, not with hatred of Jews. What is of significance is how, for Vidal, McVeigh functioned antithetically to the American idea that all behaviour is out of self-interest. Furthermore, doctors had proclaimed him not deranged but serious, with the conclusion being he had an exaggerated view of justice, his bomb just part of a war going on, equivalent to America bombing Iraq. ${ }^{30}$ McVeigh's views, if held by a non-American, may not appear that extreme. Millions of people globally believed and still believe that America's and the West's policy in the Middle East and elsewhere is essentially wrong.

There are clear parallels to be drawn. Anti-government militia movements increased from 220 in 1995 to more than 850 by 1996 , according to Vidal, with the rumour being spread that the government had planted the bomb to justify anti-terrorism legislation. ${ }^{31}$ With any atrocity a simplistic argument is to blame the government. Vidal notes that while The New York Times made mileage of skinhead neo-Nazi militias enhancing their base in such a climate, no parallel was made between the burning down of the Reichstag in 1933, which allowed Hitler to enforce the Enabling Act giving him dictatorial powers. Cries of a neo-Nazi conspiracy are often offset by cries of further conspiracies. Vidal, quoting Adam Parfrey, notes that this bombing can be seen as no different from pseudo Viet Cong units that raped and murdered Vietnamese to discredit the National Liberation Front, fake 'finds' of Communist weapons in El Salvador and so on. Parts of the conspiracy overlap with those concerning $9 / 11$. For example, no one from the Bureau of Alcohol, Tobacco, Firearms and Explosives (ATF), a federal law enforcement organization within the US Department of Justice, located on the ninth floor of the building, suffered casualties. Many ATF agents 
were not at work on the day of the attack, raising the question whether the ATF had advance warning.

Thorough forensic work on the building was not carried out, with evidence quickly destroyed, according to these theorists. This then led to President Bill Clinton signing the Anti-Terrorism Act, curtailing freedoms. Vidal's work is convincing, especially when he outlines that the FBI did not follow up on evidence, how they withheld evidence from the defence teams, and through his own investigations he finds people involved in the case the FBI ignored. For Vidal, the fact the case makes no sense makes it the 'perfect' crime. Vidal appears to have sympathy with the conspiracy theorists. For example, he quotes military generals who witnessed the carnage who confirmed it could only have been carried out by bombs strapped to the building and detonators, in an organized fashion way beyond McVeigh's means. This is also a view attached to the attack on the Twin Towers.

Stressing the role of mediated and mediatized activism, Rikke Alberg Peters has explored the neo-fascist network The Immortals (Die Unsterblichen), who have utilized a variety of new media platforms, including YouTube. Through doing so, Peters emphasizes ethno-nationalism as the wider paradigm to understand these movements. On 1 May 2011 people gathered dressed in black cloaks in Bautzen, Germany, for a march carrying torches and launching a campaign known as 'Become Immortal!' (Werde unsterblich!). Like Cobb, this protest was linked to the belief that there was a threat to the people, in this case the German people, and this was a rejection of liberal democracy. As Peters shows, mediated social and political protest often refer mainly to left-wing movements. These are known for focusing on environmental issues and anti-globalization efforts, for example. It is only natural that right-wing groups would also utilize these methods, so this is not a revelation, but some important areas need to be highlighted. One might think that this new tool would help to unify movements, but:

\footnotetext{
Although their self-representations on different social media platforms such as YouTube, Facebook, Twitter and Flickr would suggest that this is a well-established nationalist far right organization their subcultural and heterotopic form indicate that this is rather a form of collective action or a protest phenomenon than an actual organized group lest a political or social movement. ${ }^{32}$
}

This is a reaction against organized politics, and is more a deliberate protest against what is seen as the elite. In this sense, organization that is overt is against the principles of the movement. Government forces have a vested 
interested in highlighting excessive and organized home-grown extremism, as well as foreign and external extremism, given that it enables them to implement strong powers to include populations. Simply, it allows a blame culture to emerge. There is, however, an overlap between these movements across Europe and beyond. With Cobb, there is the promotion of an 'ethnonationalist myth of a golden past'. ${ }^{33}$ The desire for a cleansing is high on the agenda, but this belief has been with human nature throughout history, as evidenced by certain parts of the Old Testament where tribes not part of the chosen race, a form of the immortals, are anathema.

Manipulation is central to these developments; for example, in terms of the actual making of the content, rallies appear much larger than they are and soundtracks are employed to bolster their dramatic impact on the audience ${ }^{34}$ Engaging with the zeitgeist, this move from biological and cultural racism to ethno-nationalism has proven to be highly successful. What 'mediated mobilization' means is that new media is not merely a form of communication but it is now in itself, 'constitutive of action and physically manifests the political ideas'. ${ }^{35}$ While standard neo-Nazi rallies were formulated along very traditional hierarchical lines, the looseness of organization here means greater participation, through a do-it-yourself ethic. Combining virtual and street protest, without violence and bullying, it can be suggested that this has a deeper, long-term impact. Interestingly, it is the multifaceted nature that is also a key element of the success, given people can join protests through physical or virtual actions, but they do not have to abandon other allegiances. Ontologically, this may be a more authentic way of being because paradoxically it tunes into the multifaceted aspect of human nature.

Today we are all producers, and in this fascist movement and many other neo-Nazi movements, this level of engagement means people are finding a purpose and a way of exploring and communicating their identities through complex and overlapping methods. Time and place may not be as central now. The phrase 'may be more authentic' is stressed, given the ability to hide via new media, which could actually be inauthentic. What is significant is that there is now a blurring between producers and receivers, and activists and followers, and this means that the audience may be much wider. You do not have to sign up to far-right ideologies to become involved, as you might just have an interest in being anti-elite, using new media to provoke change. The use of the address 'you' here is appropriate, given this is exactly how The Immortals address their audience through their different methods, again to encourage personal activism away from the mainstream. Analysis of blogs and forums, for example, used by the North Belgian post-fascist 
movement reveal how these new forms allow networking that transcends boundaries of time and space, and the clips on YouTube allow for a certain form of 'immortality'. ${ }^{6}$

This opening chapter has outlined the parameters of this book with regards to Nazism, neo-Nazism, film and media, explaining the importance of identity formation and the transnational perspective. An essential paradigm proposed here is that neo-Nazi discourse has become part of the mainstream. Questions were raised over the use of the term 'Nazi' and the popularizing of Nazi chic. European football hooliganism, the media and neo-Nazism has been explored, moving onto the American context and white separatism. It has been noted how the media invented and exaggerated aspects of football violence with the neo-Nazism in football both a real and imagined phenomenon. We have seen how the science fiction book The Turner Diaries has been a seminal text in the development of American neo-Nazism and the early development of neo-Nazism in America has been outlined. The complexities around conspiracy theory have been explained, especially concerning the white separatist Timothy McVeigh. The potential of new media to promote neo-Nazi ideas has been delineated. At the start of this chapter a variety of films and television programmes were introduced. The following chapter deals with this subject in greater depth, asking whether they do offer a greater understanding, as Holocaust survivor Elie Wiesel hopes. ${ }^{37}$ 


\section{Film and Television}

\section{Memory and Representation}

We shall now explore how Nazism and neo-Nazism have been imagined on screen, beginning with Nazisploitation films, and then moving on to mainstream films and television. In the logic of the Nazisploitation film, all Germans are Nazis and all Nazis are members of the SS with all members of the SS being war criminals, medical experimenters and sexual sadists. ${ }^{1}$ These films need positioning in a wider context of other exploitation films that became popular in the 1970s, including Blaxploitation, nunsploitation, Mexploitation, 'mondo' film, and women-in-prison movies. The term itself stems from moving beyond the common practice for promotion. Germany went through a particular type of sexual freedom from 1918 to 1933, during the Weimar Republic, but this freedom was at the cost of curbing a minority. Historians of the Nazi era such as Gerhard Ritter wrongly blamed so-called sexual immorality in the Weimar period for its collapse, spreading 'cultural decay' (Kulturverfall) paving the way for the Nazis. ${ }^{2}$ This link was popularized in films, such as Cabaret (Bob Fosse, 1972).

For Nazisploitation, the films' sexually provocative marketing ruled. This took precedent over any notion of aesthetic quality. Posters contained leather-clad women with large breasts and films, such as found in the poster for Ilsa: She Wolf of the SS (Don Edmonds, 1974), which deliberately set out to look like a sex film. Oozing authority, with her hands on her hips, Dyanne Thorne as Ilsa in the film's poster is dominant. A gun holster hangs from a belt around her waist, she grips a riding crop in her hand, and she is wearing erotic leather gloves. A group scene of naked women, situated near her feet, adds a narrative, with the tag line, 'The most dreaded Nazi of them all'. Even better than this is the line, 'She committed crimes so terrible ... even the SS feared her!' The poster contained a warning: 'Some members of the public may find certain scenes in this film offensive and shocking.' But the film actually only contains five sex scenes, compared to 44 of violence and torture, leading to the conclusion that the film and those like it are more akin to slasher films than pornography. ${ }^{3}$

These films are positioned as utilizing Nazi themes in many respects for titillation, but also are significant for traversing across boundaries and exploring transgressive themes. The Holocaust is frequently situated as the final taboo. Any film that wishes to create controversy will break such a taboo to attract attention. It is easy to dismiss such films, or concur with 
mainstream critics and censors that these films are just trash, but new work on the subject has revealed how it as important to consider what some believe are just the 'surfaces'. ${ }^{4}$ Many questions arise when analyzing these films, including the ethical question concerning the use of the Holocaust in this context at all. On a wider historical level, the interest in these films did not just cease with the end of the 1970s, so in this sense they can offer up an understanding of society and culture beyond their context.

Later films build on the 1970s. This has been dubbed the Nazisploitation renaissance, with provocative films such as Quentin Tarantino's Inglorious Basterds (2009), plus the large-budget Marvel Productions and Paramount Pictures blockbuster Captain America: The First Avenger (Joe Johnston, 2011), where a Nazi officer close to Hitler is a super villain and is the face of the Third Reich. There is also the low-budget neo-Nazisploitation film Blitzkrieg: Escape from Stalag 69 (Keith J. Crocker, 2008), amongst others. There is the whole genre of Nazi zombie films, including the American Horrors of War (Peter John Ross and John Whitney, 2006), the British film Outpost (Steve Barker, 2007), which messes with philosophy and metaphysics, and the Norwegian film Dead Snow (Tommy Wirkola, 2009). Of course, gaming has utilized these narratives. The popular Call of Duty: World at War has a 'Nazi Zombie Mode', where you can kill and re-kill Nazis. Recent games such as Wolfenstein allow the player to enter the Holocaust and attempt to save Jews, much of the debate on gaming still revolving around the question of whether it is art or not, an area returned to in Chapter 5 .

Nazisploitation can become a lens and we can start seeing it everywhere. For Daniel H. Magilow even the Bernard Schlink adaptation The Reader has a Nazisploitation plot, because it concerns a former concentration camp guard seducing the fifteen-year-old Michael Berg (David Kross/Ralph Fiennes). The film then is not about the Jews at all. 'Nazi' has entered the popular lexicon, including 'Grammar Nazi', meaning those pedantic about grammar, and 'Nazi Tourette's', which is a comment on those who appear unable to control their use of Hitler and the Nazis in analogies. ${ }^{5}$ Kidult cartoons such as Family Guy have used Nazi iconography, such as in one episode (season 7 , episode 3 , broadcast in the USA on 19 October 2008) where characters wore SS uniforms with 'McCain-Palin' campaign buttons. Observed in 2017 this is even more darkly comic, given both McCain and Palin have stood up to Donald Trump. Just because this is often called lowbrow humour, it needs to be considered how and if this is any different to Shakespeare adaptations, such as Richard III appropriating Nazi iconography. Where the difference lies overall in all of this reworking of Nazi and neo-Nazi tropes is that Ilsa: She Wolf of the SS begins with the claim that what we are seeing 
is based upon documented fact. The focus is on 'medical experiments', which occurred in concentration camps throughout Hitler's Third Reich. The comment at the start from the producer, Herman Traeger, is that these characters are composites of real characters that did exist.

The point is made that the events of crimes against humanity are historically accurate, but for dramatic purposes this has been condensed into one locality. 'We dedicate this film with the hope that these heinous crimes will never occur again.' This is an interesting way of putting it, and is not the same as saying, 'to the memory of the victims of the camps'. While these words are the focus of the opening, Hitler's speech echoes out, cutting to Ilsa having sex, and her lover is then taken away by Ilsa's guards. Ilsa works with other women, dismembering her victims, and her torturing of others is framed within a medical environment. This appears as a punishment, with Ilsa fetishizing her torture tools, loving the weapons she utilizes, reflecting on her power. New women arrive at the camp and then they must parade naked in front of the commandant, with some female prisoners appearing to resent being addressed by a female doctor. Gender politics feed the power of the camp. Her male associate is unattractive, coughing, and the epitome of the unhealthy human, emphasizing her superior status further. There is a focus on the prisoners' pubic hairs, which are then removed by shaving, one prisoner resisting this process. With Ilsa: She Wolf of the SS, the basic premise asks: 'Are women better able to stand pain than men?'

While questions can be raised over voyeurism and real and assumed pain in Nazi sexploitation films, questions also need to be asked over the pornography of Nazi memorabilia. This is an example of the pervasive usage of terms like 'pornography' and 'Nazi', but postmodern critical theory has unearthed the pornography of everyday culture, which is splattered with Nazi iconography. Similarly, in academic discourse at least, there are numerous conferences on trauma, memory, the history of the Holocaust, re-interpreting and re-branding the Holocaust, through film and other forms of visual art. The aestheticizing of the Holocaust is not new, but the amount of imagery constantly reworked, through the History Channel and other platforms, such as YouTube, around the clock makes it possible to conclude that what we have here is Nazi pornography, using the term 'pornography' not to denote the actual depictions of sexual acts as much as to indicate the depiction of sensational events in order to arouse intense emotional reactions in the viewers.

As Dagmar Herzog has noted, the conflicts over sexual mores become 'an important site for managing the memory of Nazism and Holocaust and coming to terms with their inheritance'. ${ }^{6}$ Nazisploitation films stray so 
far away from aesthetics and narrative we can conclude they actually do a service to the period in history. They are enabling audiences to not just distance themselves from the events, but continually engage them with the obvious view that all history is reconstructed. However much a film such as Son of Saul (László Nemes, 2015) may appear authentic, it is a singular depiction regarding a specific period in history, which has been constructed as the embodiment of evil. What the writing on these films fails to point out is how the Nazis constructed their fantasies, which were then used and re-interpreted by film-makers. Susan Sontag explains that uniforms, for example, are not the same thing as photographs of the uniforms, and it is the latter that take on an erotic element, full of powerful sexual fantasy. Uniforms are ripe for fantasy, being concerned with legitimizing authority and violence. Nazi uniforms embody this most completely given aesthetic standards, brutality and efficiency are combined. There is a sexual element to Nazi leadership, with Hitler believing leadership was sexual mastery of the 'feminine' masses. ${ }^{7}$ Sexual elements come in to play in film, from Mahler (Ken Russell, 1974), to Pink Floyd: The Wall (Alan Parker, 1981), to Richard III (1995), to Starship Troopers (Paul Verhoeven, 1997), which all use some form of Nazi-related iconography.

On one level, it is not the films themselves that are watched and understood. In analysis of 'media' rather than film, it is the related material, be it the trailers, clips, posters, and conventions. The Night Porter (Liliana Cavani, 1974) is a significant film in this context. Here a Holocaust victim Lucia (Charlotte Rampling) re-unites with an SS man Max (Dirk Bogarde). This premise is profound, raising questions about the ongoing impact of the Holocaust on all concerned, victim and perpetrator. The plot is of note, given the two are then hunted down by SS veterans, who want to destroy the past. While the camp memories are not realistically produced, they hint not only at the stage elements of the theatre, but also at emptiness. An approach similar to this is taken at the Jewish Museum Berlin, where certain spaces are voids, indicating the erasure of the extensive Jewish culture and society in Berlin. This is the quintessence of a philosophical movement, existentialism, borne out of a number of philosophers, including the Nazi sympathizer Heidegger, and the French resistance member Sartre. Using a media of nothing to represent something is questionable, but at least it does not dictate a banal prescribed interpretation.

Condemned in The New Yorker as being a 'slab of opulent claptrap', reviews found it hard to move beyond their distaste for sadomasochism. ${ }^{8}$ The Night Porter contains a reversal of sorts. Maximilian Theo Aldorfer has been posing in concentration camps as a doctor in order to take photographs. 
Here he met Lucia Atherton, but it is unclear whether he protected her. The notion that the Nazis and the Jews, even in camps, were never having any sexual relationships is still accepted. The fact that this was anathema is taken as evidence that these relationships did not take place but needs questioning. Along with having two British stars in the lead, Liliana Cavani was the most well-known Italian female director outside Italy and had made a four-hour documentary on the Third Reich for Italian television; others included Lina Wertmuller, Elda Tattoli, and Dacia Marraini. The film's controversial themes framed the debates on Nazis' relationships with prisoners. Nazism is prevalent less directly in Italian cinema. In Pier Paolo Pasolini's version of the work of Marquis de Sade, 120 Days of Sodom (1975), he claims the environment in the film is a version of the concentration camp system.

Levels of authenticity become more absurd, with the notion of true 'sadiconazista', including The Gestapo's Last Orgy (Casare Canevari, 1977), and Nazi Love Camp 27 (Mario Caiano, 1977). All claims of resemblance to Nazi iconography, regardless of their veracity, need further questioning, given that Nazi iconography did not appear from nowhere. The Nazis were not the first system to exploit certain dress codes, the colours black and red, and mass extermination. Any fictional representations following World War II that have even oblique references to these elements might be branded as having been influenced by the Nazis, but could this be termed inevitable? The problem with such generalizing is that it removes the complexities of influence. There is within this an emphasis on 'morbid decadence and sadomasochism as the hallmarks of both Italian and German fascism'. ${ }^{9}$

Through the use of music and iconography, Richard Loncraine utilizes Nazi elements in his 1995 version of Richard III, but Ian McKellen, both star and screenwriter, plays Richard as an early 1930 s evil bounder and cad, rather than as a Hitler figure. This reflects on the British aristocratic flirtation with Nazism. The 'action takes place in a dystopian-Mosleyite version of abdication Britain', with Peter Bradshaw comparing the ruined locations to Kubrick. ${ }^{10}$ There is the overt theme that paranoia and condemnation of the other, whoever the other may be, lead to isolation - but this may be the only way to power. With brief monologues and asides to the audience, we are drawn into his duplicity. The question is, which side would we go along with in a situation in which power seemingly always wins? In this sense, he is not a lone madman or even a genius, but Richard is acting out the fundamental desire of the people. Just prior to the sequence of total devastation, when he falls into a fire, Richard has had a haunting dream in which his own demons attack him. The core paradox is that a man who 
wants to rule and be loved must abandon all real relationships. This is the route to power, indicating that this form of power is power over and through nothing. This is the real existential lesson from Hitler. An officer comforts him in the night, but his true fear is that he will die alone. This personal psychology is juxtaposed with his victor's healthy marriage bed. Isolation, in every respect, is demonized. As the tag line puts it, 'I can smile ... and murder while I smile.'

The film reveals the way in which military camps often resembled concentration camps, confronting us with the question over the status of the solider, in their own isolation. Who, exactly, is the victim? Despite the promises Richard makes, many of those working with him know they are doomed, their children slaughtered. Richard is deformed from birth. Like Hitler's abnormal testicle, mythical or otherwise, the physical abnormality is supposed to reflect on a psychological and spiritual abnormality, and his speeches about protecting ‘our women' from being raped ring deeply hollow. We already know there is no real point pursuing relationships or contact in Richard's life, making everything all the more meaningless. As with the Holocaust, a key question is why do so many people fall into that trap of following evil, and does this simply come down to fear for their own safety.

A museum on the site of the former SS headquarters in Berlin, the Topography of Terror, constructs this very narrative. Within this story, people joined the Nazis and did not resist them because they feared their own persecution. A question that this story contained in the Topography of Terror does not especially raise is around people joining the Nazi Party willingly, as a choice. The Jews have been persecuted ever since their arrival in the German region, during Roman times and in some instances burnt to death, as they were in the UK. For hundreds of years non-Jews had encouraged or ignored this. From the position of this ideology, fostered over hundreds, if not thousands of years, the Nazis' behaviour was only to systematize via technology what was actually already normalized.

General skinhead films that include Nazi and neo-Nazi references are a genre in themselves, and widely available on YouTube. They contain a number of similar themes, regardless of the nation producing them or where they are set, ranging from the extremely bizarre to the obvious. For example, Neo $\mathrm{Ned}$ (Van Fischer, 2008) concerns an African-American in a mental hospital who believes they have Hitler inside them. There is also The Believer (Henry Bean, 2001) where a Jew is a member of a neo-Nazi group. Heart of a Lion (Dome Karukoski, 2013) is a Finnish film that follows a familiar plot line. Here, a neo-Nazi has an affair with a woman with a black son. All of these films concern the premise what if your beliefs contradict your assumed 
real identity. They offer an ontological crisis as a form of plot device. In the same vein, some films reveal how anyone can become a neo-Nazi, making the important point that this behaviour could be carried out by anyone. No one is born a Nazi or neo-Nazi. In Skinning (Steven Filipovic, 2010) a Serbian mathematician joins a Nazi gang. Some very simple points are made about how joining a group like this offers an outsider some form of identity. There is a level of extremism that is startling, such as the killing of a man who is Roma. The film highlights how quickly even apparently normal people can be caught up in acting out the most extreme forms of violence, in the name of neo-Nazism. A deeper underlying question is whether this is latent within everyone anyway.

In Imperium (Daniel Ragussis, 2016) an FBI agent (Daniel Radcliffe) goes undercover, joining a neo-Nazi gang. More interestingly, the British film I.D. (Philip Davis, 1995) concerns a British policeman (Reece Dinsdale) going undercover, and joining a gang of football hooligans, the Chadwell Army. He 'turns native', getting so involved with the gang he literally loses his previous identity, and chooses to form a new identity as part of his new gang. The film ends with the protagonist marching down the road doing a Hitler salute to the police, now a total convert to neo-Nazism. None of these films especially glamorize such beliefs. Viewed now via various online formats they also work as period pieces, reflecting on the politics of the time within which they were made. The advertising for I.D. has the line, 'When you go under cover, remember who you are', the film implying there is no fixed identity.

Anti-Semitic conspiracy theorists have held the view that there is a Jewish predominance in the media and across the creative and cultural industries. This has been seized on by neo-Nazis. Long before film-makers of any nationality began their attempts to offer fictionalized drama about the Holocaust, Jean-Luc Godard made a famous statement: If ever a film is to be made about Auschwitz, it will have to be from the point of view of the guards. ${ }^{11}$ In 2010 Godard received an honorary Oscar. There was a backlash from many in Hollywood who saw him as anti-Zionist and even anti-Jewish, given his lifelong commitment to the fate of the Palestinians. It was for this that he was seen as crossing into anti-Semitism. ${ }^{12}$ Godard personally criticized films about the Holocaust, like Schindler's List and Shoah (Claude Lanzmann, 1985), on artistic grounds. Off-the-cuff remarks have been interpreted as evidence of his anti-Semitism, including a comment about the image of the Central European Jew as being part of Hollywood's problem with being caught up in debt. Organizations such as B'nai B'rith International have condemned the awarding of Godard with this honour. Danish director Lars von Trier has also been accused of being anti-Semitic 
by saying that he understands Hitler and in 2011 issued an apology for any offence caused at the behest of the organizers of the Cannes Film Festival.

The film The Reader is not really from the point of view of a guard, as it is primarily about the experiences of the guard's lover, and overall works as a metaphor for German guilt. A scathing review in The New Yorker claims the film is fatuous, outrageously turning Hanna the Nazi into a victim, and is just an excuse to view Kate Winslet 'deflowering' a boy. ${ }^{13}$ When the guard is also a Jewish prisoner, as in 2015's Son of Saul, Godard's point takes on a deeper resonance. The reason The Reader made a strong global impression was it opened a new field of inquiry, because so much had been hidden and repressed around this subject. ${ }^{14}$ There is the popular myth that it had taken a long time for the suffering of Jews in the European concentration camps of the 1930 s and 1940 s to reach deep into public consciousness, although this might be overlooking the facts. Images were in circulation even during the war. The artist Francis Bacon, arguably Britain's most important painter since the war, possessed two images from The People's Verdict: A Full Report of the Proceedings at the Krasnodar and Kharkov German Atrocity Trials, published in 1944, documenting the mass extermination of the Jews in the Ukraine. Early footage included the Pathé News footage of Belsen, screened at the Rialto Cinema near Leicester Square. It was not just artists who were aware of what had happened in Nazi Germany, but also the general public. Just following the end of the war, there was the popular display of photographs of the camps in Trafalgar Square by the Daily Express, with the motto, 'SEEING IS BELIEVING. ${ }^{15}$

It would be wrong to assume that the story of camps like Belsen, Buchenwald and Auschwitz was unknown. What this story meant or was used for is another question. At the same time, in the 20 years immediately after the end of the war there was an understandable reluctance among survivors to describe in any detail what they had been through. This is not just the case for those experiencing survivors' guilt, but for anyone who had truly experienced horror during the war. Following murder on such a grand scale it is understandable why there would be a reluctance to speak about these atrocities, at first believed to be beyond imagination. In Israel in particular the resolve to build a new country meant that older people were not encouraged to talk about the past. Often people felt ashamed of being alive when so many of their families and fellow inmates had been killed. When Primo Levi's If This Is a Man was first published soon after the war most of the 2,500 copies printed remained unsold in an Italian warehouse, people not wanting to recognize the past as there was no public appetite for this topic. 
The appearance and conviction of Adolf Eichmann in Jerusalem in 1961 brought about a shift in public understanding in Israel, while the Auschwitz trials in Frankfurt between 1963 and 1965 had a comparable impact in Germany. ${ }^{16}$ Thirty years after those trials lawyer Bernhard Schlink constructed a fictional narrative concerning arguably the biggest crime in history. How does a succeeding generation deal with the transgressions of their parents, how do they find a way of living anything like a normal life? The Reader is not simply a novel specific to the post-war German experience. As David Hare maintains, it is also a more far-reaching exploration of the difficult processes we all now know under the name of truth and reconciliation. ${ }^{17}$ This goes beyond German borders and the Jewish faith to the heart of what it means to be human.

The novel The Reader at first seems simple. In a German provincial town in the mid-1950s fifteen-year-old Michael Berg is given a sexual initiation by an older woman, Hanna Schmitz, whom he has met when he has fallen ill on the way home from school. He reads aloud to her, and they have a short summer romance which impacts on the whole of his life. Even at the time, and with so little experience, Michael can feel that the relationship has an undertow that is not wholly usual, taking him away from the life of his peers, but allowing him to enter a complex psychic world. Without warning, Hanna then disappears from his life. As an undergraduate studying law Michael attends a war crimes trial in Heidelberg discovering that one of the defendants is Hanna, who worked as a guard in a concentration camp. On the subsequent death marches she locked Jewish women and children in a church so they burnt to death. Michael realizes he is in possession of evidence about her that would serve at least to mitigate Hanna's sentence. Can he bring himself to help someone whom he has loved, but whom he feels has betrayed him? What duty does he have towards someone who has done so many terrible things?

Questions over the forgiveness that is never fully found or given make the novel and film more complex than they might first appear, making it a good case study. The Reader (Stephen Daldry, 2008) begins traditionally, examining the notion that heroes have weaknesses. This is nothing unusual and part of what many teachers on screenwriting have considered, often called the hero's journey, stemming from Joseph Campbell's now classic work on myth, which Christopher Vogler adapted into his twelve-stage hero's journey. Michael (as a young man played by David Kross) learns to forgive himself, on many levels. He eventually explains to his daughter the whole history of his relationship with Hanna. The fallout from this relationship has blighted his whole life and his daughter's, as she blamed 
herself for his inability to trust anyone. This reveals that there is hope for the next generation, given they have a great opportunity of fully understanding the past. Whether this is a choice or not is a difficult question, given it may come as a necessity for survival. The issue of German guilt threads itself throughout the narrative, with the young people coming to terms with the past so they can have a future.

In this aspect, the film is pure genre filmmaking, but this is not a negative criticism. There is a clear teleology and strong narrative drive which, along with the star status of Kate Winslet playing Hanna and Ralph Fiennes playing the older Michael, meant the film gained a wide global audience. The media attention this created highlighted the importance of examining the Nazi legacy once again. Debates around the film became part of a wider media discourse about the Holocaust and contemporary neo-Nazism. The questions raised by any 'Holocaust film' always include: How could this happen and, more relevant now than ever, could this happen again? This is Michael's film, taking us through his early sexual relationship with the former Nazi prison guard Hanna, an initiation process into adulthood, which actually keeps him stuck in the past, moving to his time at college, and to current-day philandering, and then his attempt to reconcile himself with his daughter and the past. The hope of the film is in these attempts; whether this actually works or not is immaterial. There is no point denying this potential, outlined in the narrative, claiming there is no hope in the film in an unconvincing attempt at making the film sound radically more ambitious.

Hanna claims she was following orders, as many Nazis said they were doing, and following this logic she should be commended, not prosecuted. She never truly understands her culpability, but this could be due to basic unwitting ignorance. Whether the film itself fully promotes this myth of her lack of culpability is questionable, given we are asked to doubt this. Michael is aware she cannot read, and this fact could have prevented her from going to prison for the murder of hundreds of Jews in a burning church. In court, she explains she joined the SS in 1943, after working at a factory, and being offered promotion. Her illiteracy always means she must move on before being discovered. She is then asked whether she knew what kind of work she would be expected to do, and narrates how she went to work at Auschwitz. The camp system was 'the site where the Nazi German world was most unreservedly, most unabashedly being created..$^{18}$ The camp was the emblematic institution of Germany, revealing the essence of Germany, so Hanna is the symbol of Germany. Her illiteracy is therefore problematic, implying she did not fully understand what she was doing, and therefore was not free in her choices. 
Under further questioning, she admits she was part of the selection process of those chosen to die. Being questioned in court, to ascertain whether she joined as a guard out of her own free will, she states she heard there were jobs in the SS, and that was that. The complexity of this moment is easy to gloss over, asking us to question our own free will. While free will might be limited to humans and higher animals, so is rationality, consciousness and understanding. ${ }^{19}$ All four attributes are part of Nazism, despite its condemnation as being irrational. In her innocence, she also convicts the other guards with her, who then declare she was the leader to lighten their sentences. Given we already know she is illiterate, she is portrayed as naïve, but not evil. Could this be an exception to the rule: a good Nazi? A law student watching the trial with Michael claims it is exciting, because for him it is justice, but he is soon disillusioned. This is exposed the following day, along with the shallowness of the people seeking both justice and revenge. The relevance of the Holocaust and the Jews seems irrelevant, as Michael's peer points out. This could be a criticism of the film, and those like it, that use Nazism as a backdrop. The focus on a few individuals, which is the main emphasis of all popular narrative film, removes the audience in many ways away from the collective, which is even the case in the film Son of Saul, feted for being so authentic. Is the conclusion that there is just too much horror, and humans by nature relate to the story of one individual?

The memory of a single man may represent Germany itself, as he is looking back on his childhood, memories dictating the present. After a scene revealing Michael as an adult, nonchalantly dismissing a lover in the morning, revealing he is unable to have true relationships, Michael stares out of a window in Berlin as an adult, where he sees his younger self on a tram in Neustadt. We then enter this period of his adolescence, with Hanna the conductor helping him after he has vomited. The boy's weaknesses are juxtaposed with the woman's strength, given she has helped him when he is ill, and asks him whether he has always been weak. This is a strange question, and later in court it is revealed she has a fondness for weak children, who she made read to her in the Nazi camp. Indeed, Michael at first cannot even cope with her just staring at him, when she is pulling up her stockings, and must run away. In court, Michael relives every moment of this only then realizing she is illiterate and its consequences. She has kept both secrets from him, and he feels betrayed.

What is significant is how class is often raised up as a key factor in determining neo-Nazi beliefs and actions, and how this is tied to free will. In Britain, neo-fascist groups such as Britain First are described as formed from the disenchanted and disenfranchised working classes, uneducated 
and alienated from the London-based, high-income politicians. Ideology and politics are not determined by the economy mechanistically. An approach that emphasizes the primacy of class structures is appropriate. This concerns relating their functional relationship to the capitalist mode of production, with knowledge of the social world achieved through theoretical practice, in Marxist terms known as 'science', not observation. ${ }^{20}$ Class is an element at work in the relationship between Michael, from a traditional upper-class background, and Hanna, who is illiterate, making her backstory strangely irrelevant. Hanna may appear genuine, authentic and raw in a physical sense, but she is the one who is hiding her past. His literacy writes her into existence.

Class is also tied to gender. The masculine concerns the dangerous pretence that it contains powers of discrimination and the criteria for pronouncing the truth and with femininity there is a contestation of the manner in which desire has been reduced literally or metaphorically to anatomy. ${ }^{21}$ Our centre of gravity is displaced towards a libidinal economy, to machine-like functioning, reflected in the Nazi system. Here there are echoes of the way Hanna clicks the tickets on the tram, and shuts the door to the church, forcing hundreds of Jewish women and children to burn to death, plus the manner in which she slams her fist on the desk in the courtroom. These can be construed as mechanical involuntary actions, where free will has been momentarily subverted and humanity dissolved. Her machismo contrasts with Michael's femininity, as if they have swapped traditional roles. Popular culture has emphasized and normalized the older man being involved in a relationship with the younger woman with the Lolita myth, but here this is also reversed.

Michael's fifteen-year-old body is fetishized, the camera focusing on his naked torso in the bath, when he returns to Hanna's. Sex strengthens him, and his desire to see Hanna helps him recover. In this sense, this process is Nietzschean, the nineteenth-century philosopher who worshipped the spirit of Dionysian creativity and who was wrongly associated with the Nazis. In 1934 Hitler visited Nietzsche's sister Elizabeth, who had edited his final unfinished manuscript and made the text more sympathetic to Nazi ideology. Elizabeth gifted Hitler her brother's walking stick, a symbolic and totemic object, the latter then using elements of Nietzsche's texts in his own propaganda. Nietzsche was vocally opposed to anti-Semitism but he generated the background that established that these were the times of the last men who needed to turn their backs on banal existence, the notion of the will of the most powerful being perfect for Nazi propaganda. Splitting God up into good and evil is wrong and unnatural for Nietzsche. 
The Nazis attempted to destroy all darkness, including that in themselves, by destroying the Jews, unable to fully recognize the darkness within.

There is also the tension concerning history. Should a country or an individual delve into and relive the past continually, as Michael is doing here, or should the unhistorical and even supra-historical reign, as Nietzsche maintains, to overcome the malady of history. ${ }^{22}$ Psychologically, existential psychoanalysts, such as R.D. Laing, maintained that forgetting was better than remaining, although the essential story here is based on the premise of haunting and memory. The central tenet is that we believe what we need to believe in order to live, even if this includes accepting a lie. Truth and authenticity are irrelevant. People do anything to survive, even if it means living a deadened life. Levinas has made the origin of language, meaning, and difference consist in terms of the relation to the infinitely other. ${ }^{23}$ After they make love for the third time, Michael asks Hanna her name, formalizing their relationship with specific language. There is a suggestion that she is still in many ways on the run, but eventually she tells him, which is the true moment of intimacy after the sex. A quick cut from this scene, to a lecture Michael is having on literature, reveals a parallel between his mental, formal, education, and that with Hanna. Discussing Goethe, it is maintained that character is all about the revealing of the secret, with stories always concerning either the perverse or morally sound elements of this secret. ${ }^{24}$ Michael appears to be living the perfect German adolescence and yet there is a void in his life, represented by the repression in his family caused, we assume, by their collective guilt over the war. It takes Hanna's insistence that he read to her for him to realize he is good at something. Like Hanna, he is an actor, adept at concealing his true self and wearing a mask, this in itself being his core ontological essence.

She eventually insists that the reading must come first, and then the sex, both allowing for transcendence. Once they get into a pattern of reading Michael becomes the equivalent of a rent boy, as she insists he read to her first before they make love, as if the reading is a payment. When she says he is 'good at it', meaning reading, he thinks she means making love. In this sense, he wants her to mean he is good at this physical act, rather than the mental one, although they fuse. He reads a whole series of books and cartoons to her, from Homer to D.H. Lawrence's Lady Chatterley's Lover, which Hanna believes is disgusting, and that he should be ashamed. While Hanna teaches Michael about the ways of the body, Michael teaches Hanna about the ways of mind, but overall this binary opposition is too simplistic. The first half of the film is to underline Hanna's humaneness and Michael's love for her, and to emphasize his loss when she soon disappears from his 
life. Following 45 minutes of mainly narrating the past, the film shifts to Michael (now an adult) reading the poem he wrote for Hanna when they were on a cycling holiday. Stepping into his car as an adult, he is still listening to the music she was mesmerized by in a church on their holiday. His entire life has been tainted by this affair, preventing him from being open with anyone. Paradoxically, this has protected him, the initial hurt from the loss of Hanna keeping him from future pain. At Heidelberg Law School in 1966 their special seminar begins with a reading list, specifically Karl Jaspers, and the question of German guilt. This essentially is the core of the film philosophically: How culpable are we? For Jaspers, whose wife was Jewish and who hid Jews from the authorities, there are a number of types of guilt: criminal guilt, political guilt, moral guilt, and the more complex metaphysical guilt relating to guilt by association. ${ }^{25}$

The Holocaust as spectacle is a major theme, constructed as haunting everything, not just Michael's sexuality. When the accused Nazi guards are brought to the courtroom Michael stands in the street, hoping to catch a glimpse of the criminals, unaware Hanna is inside. Is he guilty by association? The love of his life has murdered hundreds of Jews. As Michael's peer puts it, it truly is a circus, with numerous photographers inside the court as well as outside. This is already a reflection on the 'Holocaust industry', which commentators such as the Auschwitz survivor and Nobel Prize winner Elie Wiesel have maintained is deeply disturbing. ${ }^{26}$ Hanna was born 21 October 1922 and is now 43. Michael is disturbed by seeing Hanna again and he is unable to take part in any of the university students' social activities, given he is paralyzed by the past. The total absurdity of the way states operate in the modern world is underscored by what occurs during Michael's higher education. Questions are raised over the nature of civilization itself.

In his next seminar, the professor (Bruno Ganz) claims societies do not operate by morality but by law, giving the simple facts: 8,000 people worked at Auschwitz, but you are not guilty if you just worked at Auschwitz; to prove murder you have to prove intent and only nineteen of the 8,0oo so far have been convicted and, of these, only six for murder. You have to be convicted by the laws of the time and intention is everything. The following scene is an attempt to ascertain Hanna's intentions; did she actually intend to kill so many innocent people? The court scenes accentuate Hannah Arendt's notion of the banality of evil, which could be re-phrased as the absurdity or comedy of evil, some of the defendants sitting knitting, with the law students chatting, smiling and flirting.

This is no circus where the carnivalesque takes place in a Bakhtinian sense, or a moment of transgression followed by a reasserting of the law, but 
a blend between a doctor's waiting room and a school. In dramatic terms, this is more Samuel Beckett than Christopher Marlowe and Ben Jonson. During these moments, it is clear that no one is concerned about the suffering of the Jews. They are more concerned about exonerating themselves and Germany, so they can continue their distractions. The relationship between the judge and Hanna is that of headmaster and naïve, unwittingly mischievous, schoolgirl. The central drama unfolds from their conflict. From this perspective, a difficult question is: Does the truth of the events matter, or is it more the way the narrative is constructed so the court can create some sense of justice? This obvious question is at the heart of the narrative and the theatre of justice that is played out for everyone's benefit, especially the law students. Telling a story that offers the veneer of justice takes precedent over truth.

For novelist William Burroughs, language was an evil virus possessing him, which he had to exorcise through writing. What we find here with Hanna is not the antithesis of this view, but what can be considered to be the deeper horror, one that Burroughs is only implying. That is, the horror of the gap that can exist without language. Adorno stated the problem of poetry existing after Auschwitz. This is often taken out of context, and without the caveat that in his later work Adorno changed his mind. In Negative Dialetics he revised this point, claiming that suffering has as much right to expression as the tortured, and so the real question is: Can one go on living after Auschwitz? For Hanna, the answer is no, although how this relates to the Jewish experience is complex. Adorno points out that for the Jew who should have been killed survival depends on coldness, the basic principle of bourgeois subjectivity, and without this there would have been no Auschwitz at all. The guilt of the survivor is immense: ' $[\mathrm{H}] \mathrm{e}$ will be plagued by dreams such as that he is no longer living at all, that he was sent to ovens in 1944 and his whole existence since has been imaginary, an emancipation of the insane wish of a man killed twenty years earlier. ${ }^{27}$

The judge discusses a book by a Holocaust survivor with Hanna in an attempt to provoke a sense of guilt and create a fuller understanding beyond her rationalizations. In Burroughs' sense of meaning, she cannot be possessed by language or strive through writing to free herself. Hanna could never be human, making fully conscious decisions, because she never truly learned language. The people she oppressed had this privilege, being able to explain who they were. The other defendants have denied their part, only the educated knowing how to lie. As the professor has maintained, this is not about morality but law. Unaware of what justice really is, a form of drama that fits a certain narrative, Hanna thinks she is there to tell the 
truth. Hanna's absence of education makes her brutally honest: 'The old ones had to make way for the new ones.' Asked whether she did what she did because she feared for her own life, her response is intelligent and ends the discussion: 'What would you have done?'

The complexity of Hanna's trial has resonances concerning the many myths propounded by contemporary neo-Nazi groups. Some of these include: this was a just war; the Germans were just doing their duty; the guards were only obeying orders (so can anyone be blamed for acting on orders made by those higher up?); and, ultimately, the underlying belief that this process was doing the world a service, removing the 'vermin' of the Jewish people. The more extreme of these myths are essentially shied away from, in both the novel and the film. All that can be done is to reinterpret history from the contemporary period but the status of this film and its influence should not be understated. We might be forgiven for thinking the central message is that those who carried out these atrocities were basically just ignorant and the role of victim is reversed.

Paradoxically, finding a handful of guards guilty exonerates the many. This process is not about finding justice for the Jews, but a way of reconciling Germans to their past, which is still pressingly and disturbingly with them. This can be illustrated by contemporary references to industry. In 2011 Siemans had plans to register the trademark Zyklon, the same name as Zyklon B poison gas used in Nazi camps. Bosch Siemans Hausgeraete (BSH) filed two applications for the name Zyklon across a range of products, including gas ovens. Jewish groups condemned Siemans, who then apologized. As recently as 2012, Umbro apologized for naming a new model of its training shoes Zyklon. The name, meaning cyclone, may have actually been used innocently, but the influence of the media is of note. It was only when the $B B C$ News queried $\mathrm{BSH}$ about the plans for the range that they withdrew the trademark application. By 2012 Siemans, which used slave labour during the Holocaust, were involved in attempts to compensate victims, with the German government still working on ways to distribute about $£_{3.5}$ billion in compensation.

When a Jewish witness points out those guards involved, she reveals how Hanna worked with the girls. She selected people, normally young girls, and they imagined something sexual would take place. Instead she would make them read to her. At first they thought she was more humane, selecting the weak to be with her, but then she would dispatch them: 'Is that kinder?' asks the witness. This parallels Michael's life. Back at their university the student who at first said it was exciting reveals the central true point: the trial is a distraction. Why put these six guards on trial, just 
because one person wrote a book? The question of the Jews is being left out. As he puts it, everyone knew: 'our parents, teachers'. The student goes on, directly addressing Michael's professor with the question: 'How could you let this happen ... why didn't you kill yourself when you found out?'

As Michael explains to his professor, Hanna has a choice to explain that she is illiterate, if she can. This is her choice, in this instance, not his. His choice to tell the courts would undermine her choice to not choose to tell them. The judge is primarily concerned with whether she chose to not unlock the church. Survivors are included in the court scenes, but the central focus is on the German guilt and the German denial. When Michael finally visits Hanna in prison, he interrogates her over whether she has spent a lot of time thinking about the past. She thinks he means their past together. The film suggests he is obsessed with their earlier relationship, and it dominates his later life. Following Burroughs' logic, her being is the language that is the virus that he cannot exorcise. But he is judging her now. 'The dead are still dead,' she confirms. And then Hanna, with a perfect irony, uses her books to gain the height to commit suicide by hanging. Literacy literally kills her.

At every stage and at every level, it is the significance of literature that is of importance, including the memoir the witness has written. This is crucial not only in regards to Hanna, but to civilization. As Derrida points out in his discussion of Edmond Jabès and the question of the book, there is the common root of Judaism in writing. There is no history without this reflection and this furrow is the Jew. There is an interface here between the Jew and writing, a convocation (as Derrida puts it). There is a deeper conceptualizing of choice, where the question is given: What difference is there between choosing and being chosen, when we can do nothing but submit to choose? The writer is in the same position being bound to language and delivered from it by a speech that they are the master of. ${ }^{28}$ There is the continual process of unearthing the secret that is never arrived at. If we gain freedom by becoming aware of our ties, The Reader is a traditional narrative that allows for this development. Michael is a lawyer, as well as being the reader. To every question the Jew answers with a question, and the 'Law then becomes a Question and the right to speech coincides with the duty to interrogate. ${ }^{29}$

Fact is woven into The Reader just as memoirs of historical events contain records of how people ignore the facts. The Reader concerns memory and loss, memory being at the heart of Elie Wiesel's work. This work is also relevant when we come on to discuss the film Son of Saul with regards to theology, veracity and authenticity. Wiesel was born in Sighet, Transylvania, and was 
taken in 1944 to Auschwitz concentration camp and then Buchenwald. In his most famous work, Night, Wiesel reveals how no one wanted to believe the truth, as this was too horrific, including Jews in his town. Everyone wanted to trust the Germans. During British war commemorations, often turned into illustrious patriotic media events to celebrate nationhood, the position of the Jews is seldom mentioned. In this sense, there is still denial. All that is stressed is the heroic valour of men who under orders marched to their deaths. As Wiesel shows, in the Jewish community, for at least two decades after the war, no one wanted to listen to any of the stories of the atrocities, for fear of being told they were just seeking pity and the notion that it would traumatize young people.

Night reveals specifically there had already been warnings in Wiesel's Hungarian town about what would happen but these were not heeded. Deportees had been taken off, never to return, but somehow people forgot about this, living in hope. No one wanted to accept or face the truth. In the spring of 1944 the Fascist party gained power in Hungary, and still people were in denial, believing the German troops would remain in Budapest but within three days they were in his streets. Even when they had arrived, the Jewish communities were dismissing the idea that the Germans meant them actual harm, living in denial. Officers treated them with respect, buying ladies chocolates and, as Wiesel puts it, the Jews of Sighet were smiling. Even his father tried to be happy about wearing the yellow star, claiming it was not lethal, and some thought the barbed wire fences protecting their areas encouraged peace.

Weeks later, old people and babies were battered and slaughtered and people sent to the camps. Even when on the train, they believed they were staying in Hungary to work in a brick factory. The level of denial might seem astonishing, but this could be the only way to maintain hope. When at Auschwitz Wiesel maintains young men still had knives on them, despite having all possessions removed and were ready to revolt but the older religious men still had some vague hope that they might be rescued by God and told them to put these blades away. Wiesel did not absolutely deny God's existence but he did doubt his absolute justice. Others, such as Akiba Drumer, claimed that God was testing them, seeing if they could overcome their propensity to despair, and that any form of punishment is a form of love. ${ }^{30}$ This extreme belief is disturbing.

What is seldom discussed is that the altruism of some guards towards young children was down to their paedophilia. ${ }^{31}$ Drumer claimed that he had discovered a verse from the Bible which, when translated into numbers, 'made it possible for him to predict Redemption in the weeks 
to come'..$^{22}$ These were Jews who, in the main, believed the messiah was returning, so in this sense the more severe the hardships the greater evidence there was for this return. In a wider context of altruism and love, this is difficult to fathom, but the greater the punishment within this theology the more tangible God's love. When Wiesel is in the infirmary at Buna, the man in the next bed explains: 'I have more faith in Hitler than anyone else. He alone has kept his promises, all his promises, to the Jewish people.' 33 This is the position of someone who believes he is totally abandoned.

When the camp is being evacuated, Wiesel has a choice; to remain in the infirmary or leave with most of the rest of the camp - he chooses to do the latter. If he had stayed, he would have been part of the liberation three days later, but he also would have had to endure further hardships. They leave running like machines, Wiesel behaving like an automaton.

We were the masters of nature, the masters of the world. We had transcended everything - death, fatigue, our natural needs. We were stronger than cold and hunger, stronger than the guns and the desire to die, doomed and rootless, nothing but numbers, we were the only men on earth. ${ }^{34}$

Wiesel does not shy away from the moral choices people were making at every turn. Should you stay with the sick and lame, and limit your chances, even if this means death, or do you abandon people, even your father, if this means the possibility of survival? After days of starvation on a trek, after leaving the camp, one man hides some bread in his shirt, only to be beaten to death by another man, who turns out to be his son. ${ }^{35}$ The son is then beaten to death by other starving men who want the bread.

The narrative is a father and son story and here the moral choices remain stark. Wiesel is advised by a doctor to eat his father's rations just so he will survive with his having been beaten by fellow inmates. In the original version, published in 1958, Wiesel comments on how within just ten years since the end of the war, those who were Nazis are once again in power in Germany, and that in many respects silence reigns. Plus, anti-Semites throughout Germany, France, and the United States, are claiming that the assassination of 6 million Jews is just a hoax. According to Wiesel, if there is anything we can learn from Auschwitz it is responsibility. In 1978, Wiesel maintained that all his work was about inventing and reinventing characters from his childhood in Sighet. Even after the success of Night, Wiesel is not sure that writing it was the correct thing because the Holocaust 
is, in his words, a fashionable subject. This he believes is more offensive than ignorance of the subject, although he is compelled to write about the Holocaust, and for him there is no choice. Night came from a 9oo-page manuscript, which in 1978 he claimed he may publish one day as a whole, as it does not belong to him. Wiesel's claim to not own his manuscript is not unusual in the arts overall, with many writers and painters believing they are the vessels and transmitters of discourse.

Wiesel's text had a major impact internationally and is a nuanced approached both theologically and with regards to the transmission of memory and the notion of authenticity a theme addressed next. Feted for its apparent authenticity, László Nemes' 2015 film Son of Saul set in Auschwitz in 1944 concerns a man who finds the body of the boy he thinks is his son who he wants to give a proper burial. A doctor allows him five minutes at night to take the dead boy away. In 2016, the director Nemes found writings by the crematorium workers in the camps and her had relatives who died in the war in 1944. He was told about these deaths in his family at the age of five, with his mother not sparing him any of the details. There is then an attempt at authenticity. For Nemes, the history of the camps is about death. This might seem obvious, but globally their history appears to be more about annihilation, a step beyond death, where death is not recognized.

Popular culture has this as a central paradox, appearing obsessed with death but in general in denial. ${ }^{6}$ Fiction films had been primarily about survival, but the camps were about death, so this in itself has been about rewriting history through film. What might be conceived to be the 'unimaginable' needs to be imagined and the skill for any artist is to suggest it, so the imagination of the viewer can construct what they need to. The point for Nemes is not showing or telling too much, which is the case for all good creative work. After many attempts to find funding, only the Hungarian Film Fund agreed to finance Son of Saul, suggesting it is still difficult to make art about this difficult topic. (A Tale of Love and Darkness, a film in Hebrew about the birth of Israel after the Holocaust directed by Natalie Portman and based on the memoir of novelist Amos Oz, was released in the same year.)

The protagonist is a Hungarian who only arrived at Auschwitz-Birkenau in 1944, at which point the Soviet Army was thought to be approaching, so the murder was accelerated. ${ }^{37}$ The majority of critics stated the film was an immediate classic, as it claimed to be speaking about the unspeakable from a new viewpoint. There is some truth in this, but it is overstated. The film begins with randomness and chaos, which can be considered to be 
authentic. The handheld camera is always over the shoulder or behind the protagonist, inviting us to construe his presence within the midst of the camp. Are we supposed to conceive of ourselves as some form of conscience, or consciousness, of Saul (Géza Rőrig) as we become one with the camera following him around over his shoulder? Here we are brought into Saul's world, sitting on his shoulder with the camera, like a devil in hell, or like a God who cannot or chooses not to intervene.

Half way through the film a child does hold a camera to take photographs as evidence, but the camera making the film being positioned from predominantly behind the protagonist is problematic. The deception and denial of all those involved is portrayed nonchalantly. And then we have the shower-gassing scene. Nothing is shown, but the indication of the horror of their death is gathered from the screams of the victims and the banging of those being murdered. If the director wants to leave a lot to the imagination of the viewer, then this includes the most difficult sequences, such as this. Is it that such horrors are too much to convey or that, ultimately, at the time at least, this was supposed to be kept a secret? As with all major narrative films, the focus on the individual means we do begin to relate to that individual, but this also means we might neglect the collective and the group. There is the implied view that anyone would do the same as Saul, working for the Nazis, just to stay alive a few months longer. There are other films that attempt to tackle difficult issues, such as the end of the world, but focus on more than just one singular protagonist, offering a glimpse at the collective and social organization.

This focus on the individual includes those who have just been murdered, given one boy has survived is quickly murdered by the hands of the Nazi who wants an autopsy to find out why. Another name for Saul's kind is 'bearer of secrets'. There is the potential of hope here, given anything can happen if one is given a stay of execution. Once Saul believes he has found his dead son he approaches a rabbi who is shot due to Saul's encounter with him. Are we supposed to accept that someone would do anything to enable the religious burial of their son or is this psychosis? It might be concluded that this is actually an attack on the futility of religion that places the position in the afterlife as more important than the real world. Even if value in the afterlife brings value in the current real world, Saul's action have meant one man has died in vain, unwittingly punished for not carrying out his rabbinical duties. The paradox is that within Judaism the afterlife is not emphasized anyway, but it is the burial process that is important. This is a statement against the carnage around him. 


\section{Childhood and Adolescence}

While not a film especially aimed at a younger audience, Schindler's List (Steven Spielberg, 1993), given its impact and global audience, needs mentioning. In many respects, this film has come to exemplify the Holocaust. The film has decisive facts about the Holocaust prior to the closing credits, such as 6 million Jews died, and there are only 4,ooo left in Poland, but globally there are 6,00o Schindler Jews. Even with dead and alive naked bodies in camps, the film explores humanity within with the horror of this experience. Women prick their fingers to extract blood and then make their faces rosy, to appear healthy, and carry out other activities to keep alive. This strong focus on the living offers hope. Ralph Fiennes plays Nazi officer Amon Goeth who is in love with a Jewish servant and unleashing his anger on random Jews.

At one point, when his gun gets stuck, he is laughable. Should we take him as epitomizing the German Nazi state, or does this focus on one individual allow the audience to conclude that it is his personal psychology, not Nazi propaganda, that allows for such extreme behaviour? Despite this, Schindler (Liam Neeson) manages to change Amon's psychology. Schindler's philosophy is there is more power in forgiving people. An important aspect is that the film is shot in black and white, which many people campaigned against, believing it would stylize the Holocaust. Spielberg had only experienced the Holocaust through testimonies and archival footage, in black and white. In this sense, the film is a dramatization of Spielberg's research, but it ends with the Schindler survivors and their relatives. For this reason, it is a statement against neo-Nazi propaganda.

Inglorious Basterds (Quentin Tarantino, 2009) is a form of reverse Western, also with a focus on hope. While not aimed at adolescent audiences, the Tarantino brand and oeuvre originally appealed to youth culture, which is not tied to chronological age. Brad Pitt's gang of American soldiers goes hunting German Nazi scalps. Pitt's character, Lieutenant Aldo Raine, has a trace of 'American Indian' blood in him, and there is comedy in his ruthlessness. While Pitt's gang hunts Nazis, this is paralleled with Nazis hunting Jews. The wider context, given the period of the film's release, is Islamophobia, and the attack on anyone 'other', including those fighting against paedophiles. Tarantino employs a typical revenge narrative, which leads to the question: Is the context important at all? Paradoxically, while Tarantino has been attacked for changing history, his fictions address topics that history has overlooked. The uncanny malevolence of the Nazis, while not overtly celebrated, is depicted. As with other culture about the 
Nazis, neo-Nazis may use the film as a form of celebration, despite the film focusing in the main on the anti-Nazi team, but this is not the essence of the film. The film celebrates the individual over the state, mocking those who operate out of 'national pride', such as Frederick Zoller played by Daniel Brühl. The film does raise neo-Nazi issues. For example, What exactly is anti-Semitism? Was the aim of Nazism to have one language and one dominant culture, globally?

Key experts on the Holocaust, such as Elie Wiesel, often place some of the outcomes of the Holocaust on Jewish theology and the Jewish promotion of suffering as a virtue. This denies the resistance and rebellions that took place, such as those organized by Jewish prisoners in Treblinka, Sobibor and Auschwitz-Birkenau. Tarantino's fiction film accentuates this resistance further, to incorporate the notion of Jewish vengeance. Whether this is authentic or accurate or not is irrelevant here. Raising the issue of Jewish vengeance is important, because it has been significantly overlooked historically, and theologically, despite the Old Testament God being one of vengeance. At Le Gamaar Cinema in 1944, Reich Minister of Propaganda Joseph Goebbels (Sylvester Groth) is screening Nation's Pride for the Nazi elite, including Hitler (Martin Wuttke). The cinema is discussed like a church, with the broadcasting of the ultimate Nazi propaganda film to venerate the new Reich. Shosanna Dreyfus, the owner of the cinema (Mélanie Laurent), a clandestine Jew who has escaped from the Nazi Jew hunter in the opening scene, intends to kill all the elite through a fire in the cinema, splicing herself into the film as 'the face of Jewish vengeance'. Tarantino invites us to question whether authenticity is attainable or actually necessary. The fact the film is difficult to place, genre wise, challenges the audience. Setting, language, and period are all correct, with the attention to detail offering a beautiful verisimilitude, but characterization is exaggerated, not to the extent of parody but almost. Rather than denounce the director's use of violence, it is important to understand how Tarantino's use of violence as a director is, ironically, actually authentic in its very postmodernism.

Moving to a genre aimed specially at adolescents, it would be excessive to state that The Hunger Games film series takes its iconography, everything from its fashion aesthetic to set design, from the Nazis, or even the Nazi era. But a quick glance at even just a trailer for any film in the series indicates what has been absorbed from the Third Reich and fascism in general. Take the rebel salute, for example. This seems more like an Italian fascist salute, rather than a German, but it is still a fascist salute. The Italians used this form of salute in the 1920s, which was then adopted by the Germans in the 1930s, but there is no clear agreement on whether this practice was 
ever employed in ancient Roman culture. Evidence from sculptures hardly points to a standardized salute. Here, in the main, it referred to specific victories in battles.

The film series is based on a trilogy of books for young adults by novelist Suzanne Collins. In the film The Hunger Games: Mockingjay - Part 2 (Francis Lawrence, 2015), the rebel attire consists of jump suits. This is commented on self-consciously by Effie Trinket (Elizabeth Banks), a stylist from the Capitol who is now with the rebels. She does everything she can to point out how dreadful life with the rebels is. She is there for comic continuity, but concurrently she indicates that everything worn can be reborn and worn again. This adds to an unsubtle attack on capitalism, which thrives on a disposable culture, both in products and people, a theme Star Wars: Episode VII - The Force Awakens (J.J. Abrams, 2015) also plays with, having the central protagonist surviving as a scavenger. The Holocaust is the extreme form of disposable culture, where those not fit for work and production are murdered.

Where this film in the Hunger Games series really becomes part of a Nazi legacy is in the filming of District 12. At first the heroine, Katniss Everdeen (Jennifer Lawrence), wants to go back to see what has happened to her district, and witness the true devastation, promoting the notion of affect that things must be experienced in the flesh. This is also a device on behalf of the rebel high command, to jolt her into action, and make her become their figurehead. Of this, she is oblivious. A further tactic is to use her to make propaganda movies, to show to all the districts and broadcast these to the Capitol. The film questions how women are used and manipulated as pinups. She returns to District 12 with a film crew who want to capture her authenticity. The Nazis made propaganda of this sort an art form, hence in this regard the film can be read as taking its cue from the Nazi era.

Paradoxically, the postmodern era appears to be concerned with the term 'authenticity'. To understand the world as play circumvents extremism and neo-Nazism, given in the latter there is a lack of healthy doubt in doctrines. Katniss has tried speaking her lines on camera in a studio, with an artificial backdrop and this has been disastrous. People realize her strength is in her genuine, heartfelt reactions to situations. Both sequences use the same framing of the burnt bodies in a war zone, the people escaping being burnt alive. The destroyed District 8 and District 12 obviously resemble bombed out areas of Germany. When there is an air raid and a hit down below in the vaults of District 13, it is difficult to not compare the arrangements of the bed bunks to the Nazi camps. The postmodern repetition of war footage on television channels, such as the History Channel and Yesterday, adds 
to the influence of the World War II aesthetic. The ability of the viewer to channel surf and intersperse viewing with selected viewing on various playback formats does not detract from the deep level of ingrained viewing via these other channels, where footage is fetishized. In many ways, the footage becomes a series of images outside of time and history, despite the voice-over narration and positioning of the images within the wider narrative.

The world in The Hunger Games, especially the Capitol of Panem, has a Nazi aspect to it with its work ethic, but so has capitalism itself. According to this ideology, as with Auschwitz, work will set you free. When the leader, President Snow (Donald Sutherland), addresses Panem, he claims the rebels' actions will damage the peace, which is only achieved with everyone doing their collective share. Ideologically, this sounds like National Socialism. These citizens have a contract, which includes the yearly human tribute they give from each district for the games. Like Aztec sacrifice, it is embedded by the hierarchy that the only way for the whole of Panem and the districts to survive is for each district to offer up a human being each year to fight in the Hunger Games. This blood sacrifice is payment, and also works ritualistically and is a form of religious rite of passage for all involved.

The difference with Nazism is the aim of Nazism was to rid the earth of the Jewish race, whereas here the sacrifice is an intrinsic aspect of an imperial domination, based on class not race. This was the key specific aim of the war for the Nazis overall, with world domination secondary to this mission, but inevitably both went hand in hand. The extermination of the Jews was not a side issue for the Nazis or for Germany in general. The industrial process by which this was carried out was intrinsic to the Nazi war machine. We need to be careful in claiming this was an industrial process. As Richard Evans has shown, this suggests an automated process, away from the humans involved, plus the process was not an efficient one. ${ }^{8}$ The ritual of the game, satisfying Thanatos, or the death wish, has a religious trait. This is a future world, where traditional religion seems to have vanished, and where the unity that may have come through rituals and sacraments in the past comes through this bloodshed.

Using multimedia in all its forms, the broadcasting of the games keeps everyone enthralled, just as multiple channels today, be the content real or imagined, past and present, keep everyone 'entertained'. The plethora of images, in an image-dominated world, has led to the conclusion that images have a higher value than truth. Regardless of the desire, a return to the real is still yet to be achieved. Richard Wolin in The Seduction of Unreason condemns thinkers such as Nietzsche as being 'glib'. ${ }^{39} \mathrm{He}$ finds it 
offensive when Baudrillard writes that we have 'dreamt' of September 11, 2001, forgetting that this terrorist attack was not a single event that came out of nowhere, situating events of this nature in a vacuum and denying any causality in any direction. As noted with reference to Badiou, the real horror is when all thinking is cut off and all we are left with is an incontestable Truth. This nostalgia for the days where everything was apparently solid and unquestionable deifies the past and history, making it impossible to understand.

In The Hunger Games the mediated 'games' keep people away from protesting about their own conditions in the districts, which are of a far lower standard than those of the Capitol. The state centre keep informing the Districts they are lucky to be there at all, and this is the only way to keep the peace. In terms of science fiction, here we have the traditional dystopian and utopian paradigm, combining aspects of George Orwell's 1984 and Aldous Huxley's Brave New World. Analogies to the contemporary situation regarding terrorism are overt. Globally, governments perpetually develop an enemy, instilling fear and complicity in the populace, allowing them to be subjugated and the dominating regime to remain in power. There is a complex relationship between the government and the press in enabling such a power relationship. In a popular trilogy of books adapted into four films, the complexities might not be nuanced, and yet the message is strikingly familiar. Katniss herself is no revolutionary and does not believe in any new ideology propounded by the revolution, but seeing District 8 destroyed compels her to makes propaganda movies that generate the popular message: 'If we are going to burn, you are burning with us.' Call this a nihilistic, or even a punk ethic; far from generating nihilism it generates activism. In this sense, it demonstrates the exact opposite of what Wolin finds in the Nietzschean ethic, and is refreshingly life-affirming.

Often it is difficult to see that questioning all forms of the construction of reality is benign, but this is inevitable when questioning challenges power. Those locked into the establishment (those whom Wolin defends), will try and resist any change to the status quo, be this in critical theory or in reality. Importantly, protest movements generated by students, and by those who have had enough of austerity across Europe, occurred at the same time as this film's release. The rebel against the system is what makes these films so popular to the teenage audience. In this sense, it does possess a certain level of veracity and, like all good science fiction, mirrors the contemporary. How far we take this analogy into real politics is a good question. Here the hunters of animals, like Katniss, become the hunted. 
Many may believe the Nazis were innately evil, while others conclude that their actions were evil, or even monstrous, or they were actual monsters. With Nazism and neo-Nazism, metaphors often get blurred in popular culture. Miss Peregrine's Home for Peculiar Children (Tim Burton, 2016), based on the novel by Ransom Riggs, refers to Nazis as monsters and here there are real monsters. Jake Portman (Asa Butterfield) and his grandfather Abe Portman (Terence Stamp) have a peculiarity for seeing monsters, called Hollows. There is never anything explicitly mentioned, other than by Jake, but it is assumed that the children in Miss Peregrine's home are not only talented but are what today would be termed 'special needs'. They are stuck in a loop, 3 September 1943, when a Nazi bomb was dropped on their home in Wales, and they repeatedly relive the same day. We know that Jake's grandfather had to leave Poland and enter this home because 'he was special'. When Jake confronts his grandfather about the peculiar talents of the children he suggests the term 'special needs', only because his classmates have been mocking him for believing the stories, such as the existence of a boy who could make himself invisible.

For Geoffrey Macnab, the monsters look as if they have stepped out of a Francis Bacon painting. ${ }^{40}$ Bacon was influenced by the Nazis, so this comment is appropriate. In this film, the Bacon Nazi aesthetic comes through in the form of the monsters that only the main protagonist can see. Unfortunately, critics like Macnab and Lenika Cruz, writing in The Atlantic, appear to have only watched the film once, and then blame their lack of understanding on the plot not making sense, or the film not even having one. ${ }^{41}$ Cruz wants the film to continue its seriousness, with its early references to the Holocaust, while at the same time saying it does not have a heart. A film largely set in 1943 must make references to the Holocaust in some way. The ethics of how we portray elements of the Holocaust can be questioned but to state that film narratives should stick to being serious is didactic. As with Tarantino's aesthetic, Burton here transgresses the limits of genre by producing an original children's film that tackles a difficult subject. More significant is the manner in which Abe tells stories and what is left unsaid, suggesting that the larger gaps in history cannot be resolved easily. Abe is demonized as monstrous by his own family, and is thought to have dementia, apparently making up stories to tell the young Jake. When asked follow up questions, he does not want to talk about it, and this is assumed to relate to the traumas around the Holocaust, which he may have witnessed but escaped.

The Hollywood Reporter attacks the scriptwriter Jane Goldman (cowriter of two X-Men and two Kingsman films) for the third act, claiming 
the comic villain Barron (Samuel L. Jackson) is moving us away from the Michael Powell-style romance, which would create a more poignant film if sustained. ${ }^{42}$ This is suggesting that a film should only remain in one genre, and ignores decades of recent cinema. Jackson is a well-known actor, often appearing in Tarantino films, and Barron's funny one-liners make direct reference to Tarantino movies. The skeleton action sequence on Blackpool pier is not the first reference in the film to Don Chaffey's 1963 film Jason and the Argonauts. Enoch's peculiar power is to bring things back to life, the film offering a precursor to the third act, when Enoch shows Jake his skills, inserting hearts in scraps of animals and dolls and getting them to fight for fun. The odd thing about these peculiar talents is that they appear so natural. There is a questioning of bifurcated thinking, allowing us to go beyond the narrow stereotypes. Despite all the references, the Nazis remain explicitly anonymous, as if they can never be caught, reversing Tarantino's scenario. Fundamentally, the film makes the observation that history cannot, and should not, be escaped.

\section{X-Television}

The overlapping debates concerning Nazism and neo-Nazism on screen were played out in 1997 when Roberto Benigni was awarded a best actor Oscar for Life Is Beautiful (Roberto Benigni, 1997), set in a concentration camp and in the same year Ed Norton was nominated for playing the redeemed neo-Nazi Derek Vinyard in American History X (Tony Kaye, 1997). Norton took control of the film, and a battle commenced with Kaye filing a \$200 million lawsuit to have his name changed to Humpty Dumpty on the credits. Named in the global market after the Norton film, Netflix's television series NSU German History X (Christian Schwochow, Züli Aladag, Florian Micoud Cossen) examines the rise and fall of Nationalist Socialist Underground (NSU), an actual neo-Nazi terrorist organization in German. Historically, NSU was responsible for a series of crimes, including: killing eight Turkish German citizens and one Greek immigrant between 2000 and 2006, known as the Bosphorus serial murders; murdering a policewoman and attempting to kill her colleague; the 2001 and 2004 Cologne Bombings; and fourteen bank robberies.

The first episode begins by claiming this is not based on actual events, despite the names of the characters being those in the real NSU. The threepart series merges with documentary, using real footage. ${ }^{43}$ The movement was based in East Germany and was dedicated to creating a new fascist 
state based on Nazi principles. Over the entire period they were operational there was a shift to the right across Europe, with an increase in the number of racist attacks. From this perspective, right-wing groups are protected by the centre and this is exactly what happened in Germany, and elsewhere. The white terrorist group killing German citizens were allowed to carry on their atrocities with the police blaming the very groups who were being murdered. Beate Zschäpe (played here by Anna Maria Mühe) was committed to trial on 31 January 2013 for ten counts of murder. She broke her two and a half years of silence in December 2015 and made a statement, saying she had known NSU members but had not been a member herself. She blamed Uwe Mundlos (played here by Albrecht Schuch) and Uwe Bőhnhardt (played here by Sebastian Urzendowsky), and issued an apology, claiming she could do nothing to stop them.

The character arc in NSU German History $X$ reveals the central character Beate as a shy girl with a difficult home life establishing an identity in this neo-Nazi group. Falling in love with a neo-Nazi, she needs to prove herself to the group and to him, doing so by robbing an immigrant, firing a fake gun, and calling for real violence. Despite the orders coming from Berlin regarding clearing immigrants from their town, the show is clear that Beate planned a systematic form of violence that galvanizes the group. She is to blame, despite being the one at first easily led. Before she joins the gang and becomes its catalyst, the group is mainly a bunch of thugs, dancing to neo-Nazi music. In a subtle sense, the first episode indicates this is her survival mechanism. She is getting nowhere in her former life; joining this neo-Nazi group is the way she can save herself and stay alive.

All sides can use violence. When her neo-Nazi gang attacks a group of young people she protects her former friend Sandra (Nina Gummich), revealing this neo-Nazi identity is not her ontological core. Beate goes to the job centre, where Sandra is working unaware of Beate's current behaviour, but still carrying a scar from the previous attack. Beate appears turned on and excited by violence, kissing Ribby passionately after he attacks a man with a glass. Her behaviour, however, appears inauthentic. Uwe joins the army and is asked to be an informant on right-wing actions, but he tells them this is treason. Similarly, someone from the government approaches Beate when she is reading a travel brochure about Romania, saying they are looking for informants on right-wingers. The plot reveals how close the authorities were to all of their activities, allowing these activities to continue for their own purposes. This can be framed as state-sponsored terrorism.

We are asked to question our own complicity. One of their most disturbing activities is when Beate orders a woman with a baby to state repeatedly, 
'I will not traipse on the lawn', causing the baby to wail. The simplistic enjoyment of power is portrayed expertly. While it is not made clear that the woman is an immigrant, or Jewish, Beate looks at the camera for the first time, breaking the fourth wall. This is a form of challenge to the audience: 'You think this is bad?' It also suggests nothing will stop them, that nothing is sacred. And it is a way of questioning the audience's enjoyment. Ethically, what should we be participating in, as an audience? With her look at the camera, there is recognition that in some senses we are also complicit in the violence.

Beate reveals her love for children via her friendship with Sandra, but also revels in a nursery being part of the Oklahoma bombing. Killing children is seen in this mindset as enjoyable and entertainment, not just part of their mission. NSU German History $X$ directly shows how the neo-Nazis in Germany mimicked white separatists in the USA. Watching the news of the Oklahoma bombing on 19 April 1995, when 168 people were killed, including nineteen children, gives Beate the idea of carrying out an explosion. The text they follow is not Mein Kampf but an American text, The Turner Diaries. The frustration amongst the youth appears to be with the older generation, who will do nothing to stop their supposed oppression by the 'other'. While Beate physically fights her mother, Uwe screams at his father that he would 'turn up the gas chamber myself'. He sees it is disgusting that his mother works for low wages, and his professor father is also poor with, in his words, 'their salaries being dictated by Jews from Bonn'. When his father calmly tells him there are no Jews left he dismisses this.

Could this form of programme actually promote neo-Nazism with a young audience who may not have been aware of the movement at all? While Beate and her young friends are repugnant, the adult world appears to be totally anodyne, non-committed and conformist, revealing the gap which neo-Nazism can fill, and almost suggesting there is no choice. The adult world is the world of the zombie, their brains having been removed by being slaves to the state. The neo-Nazi youth culture is in many ways resistance to the adult world, living in a post-war malaise. It is not so much the glories of a victorious Third Reich, looking backwards, that the neo-Nazis want to recreate, but a future. Beate has no job, with no real opportunity for getting one. These circumstances do not automatically lead people into becoming neo-Nazis, but it is the circumstances that are offered here as a part of the subtext of her trajectory towards fascism.

In a secret location, before they get the idea to plant a bomb, the gang listens to a neo-Nazi folk singer's lyrics about causing explosions under parliament. Subcultures, group pressure and propaganda are all revealed 
as relevant to instilling neo-Nazi ideology. Interviews for Leo Regan's documentary British Neo-Nazis, with ex-neo-Nazis, reveal that the promises of neo-Nazi groups are where they manage to win their following. For one disillusioned man, he became a neo-Nazi because he believed their propaganda, thinking that a Fourth Reich was on its way to create a place where there would be no gay men, men in dresses, smashed bottles, or drug addiction. Published on YouTube on 22 October 2013, this had generated 1,630 comments, including, 'This is not National Socialism. These people are not National Socialists. They are themselves subhuman genetic trash.' This gained sixteen likes. There is also resistance to this racism online with another comment: 'The true skinhead is apolitical and anti-racist, my homeland is my neighbourhood.'

In the music scene in NSU German History $X$ the folk singer at one point uses the word 'magic', stating that this is about transformation. Without the dress, the music, and the collective rituals there is no 'magic', just the boredom of their parents. This is not a movement that is attempting to change people's minds and behaviour. They move towards violence via imitation and are neo-Nazis in this sense by affiliation, not by action. Indeed, as they become extreme, moving underground, they paradoxically become more part of the mainstream, their existence enabling mainstream society to function. The third part of the series focuses on this theme, with the police destroying evidence, and being part of the neo-Nazi group, with ties to Blood and Honour, a group banned in Germany since 2000.

While the politics is a game, the violence does have consequences. When playing a neo-Nazi board game, Beate once again looks at the camera provocatively, as if the viewer is her mother, who might correct her. This glancing is not sneering, and works as an invitation to share in her excitement, to become part of the action. Behind this is the notion that despite this being overtly about neo-Nazi belief, covertly this is about anarchism, and the rejection of the status quo. The skinhead culture that arose after punk in 1976 was formed in a period when there were few opportunities for young people. The neo-Nazis tapped their need for order and a created a framework to galvanize the energy of the young. The physical training adds a military side to the gang, Uwe the leader despising those skinheads who get drunk and waste their lives. Beate documents the events through photographs, indicating that this is her telling her story and mapping their lives. Uwe has become educated in the army and at college, translating the first ten pages of an American text, The Turner Diaries, into German, believing this is their future.

Their first choice for planting the bomb is Buchenwald. For the NSU, Buchenwald is worshipped as a sacred site for the wrong reasons, and it 
should be destroyed. The first episode ends with the gang's car being blown up. Their violence can be construed as revenge, or at least reveals their own incompetence, asking us to question whether this is one of their own explosives going off. They have planned planting a bomb but at this stage they have not reverted to violence. On-screen text explains the true events behind the series: there is a first victim and then nine more, and states that a number of the scenes with Beate are fictional because no one really knows what happened. With legal procedures running, the film-makers are not prepared to overtly connect Beate with some activities concerning the neo-Nazi violent activities, as she denies her culpability, especially concerning the garage and bomb making.

Twice she is the instigator of extreme violence constructed in a genderspecific way. The young men need to prove their virility in front of Beate, by taking on these violent tasks.

While the first episode focuses on the gang within a gang, the second focuses on what we assume are their victims, the Turkish community, and the wider complicity of Germany. The first episode has long sequences where often nothing more occurs than young people drinking. Aesthetically and narratologically, the second episode is superior, moving backwards and forwards in time and space, making better use of prolepses and analepses. The murdered man's origin is visually significant and the cinematography more expansive. The action moves back to the present, his shifting consciousness on his deathbed compounding our awareness of his life, and that of his daughter. The neo-Nazi forum www.stormfront.org, which has the stated aim of promoting white pride worldwide, has in its comments section on the programme that this is all propaganda anyway, although the 'first part is worth watching'.

Neo-Nazis enjoy seeing themselves on screen, in any form, so it seems, even if their actions are random and moronic, but are unable to see the value in the second episode where the Muslim point of view is depicted. The second episode makes it clear that neo-Nazi beliefs are not at the fringes of society, nor are they in any way extreme in this context, but they are at the heart of the German system. This raises the question, if we position this belief as belonging to the outsider, do we then remove any ability to confront them. This show explicitly states this is the case, given the complicity of the police, as revealed in the third episode, where members of NSU are protected as informants. But if these beliefs are at the very heart of society, intrinsic to society's functioning, is there any possibility of resisting or subverting them?

'Anything is possible in that environment,' states the police chief. It is immediately assumed that the killer must be a fellow Muslim, as the police 
believe they are savages. The second episode immediately reveals the racism of the police, and their complicity with neo-Nazi behaviour, but the third episode is focused on the police behaviour. The Turkish family is aware of the blatant racism in Germany, and the endemic Nazi beliefs, but the police will not tolerate any suggestion of this. One investigator at the home of the dead man states, 'there will be no mention of swastikas or Nazis', despite the dead man's cousin having his restaurant in Berlin burnt down by neo-Nazis. The level of denial is severe. At no time do the police consider this murder was caused by someone outside the Muslim community. The violence, according to the police, is caused by this racial group themselves, with even the murdered man's wife becoming a suspect.

Obvious parallels exist. As with the neo-Nazis in the first episode, who scream at their parents for just sitting back and accepting the oppression of the system, the daughter wants her mother to fight back. The mother's compliance stems from her having been saving money without paying taxes. Once this is discovered, this is additional evidence to the police of her husband's murder being carried out by someone who knew him. One of the investigators states this was more like an execution than a killing, but there is no hard evidence that this is killing driven by neo-Nazi hate. Retrospectively, treatment of the family can be conceived as being racist, and is constructed as asinine, but they are attempting to find the killer following traditional detective work. They have a family vehicle wire-tapped, only to learn comically that the wife of the victim is concerned the police have not eaten enough. Muslims are depicted as the new Jews, the contemporary German state in part neo-Nazi. We have a neo-Nazi attack followed by neo-Nazi-style investigators interrogating the new victims, the neo-Jews. This comparison is more complex than initially appears. The wife of the murdered man openly prays in the police station, not hiding her religion as a persecuted Jew might do. The neo-Nazis are anti-law and order, and not on the side of the police. Indeed, they soon kill and maim police officers. Their philosophy is to overturn the state, which they believe has catered too much for immigrants, the praying in the police station right by a desk, whether realistic or not, being indicative of this.

\section{Conclusions}

Racism as a general term was originally spawned out of Hitler's construction of the Jews, as a 'race' to face genocide. There have been periods when the Irish and Italians were considered 'black', and a lower race, but through 
time they became 'one of us'. Through an exploration of works for film and television the tensions between how Islam is perceived within Nazi and neo-Nazi discourse has been elaborated on. Writing in The Jewish Chronicle, Julie Burchill vehemently denounced the view that Muslims are the new Jews. Burchill claimed these comparisons were wrong because Muslim immigrants are mainly men, unlike those of the Kindertransport, and that immigration caused sex attacks in Cologne. She writes that Chinese and Indian people, along with Jewish, are innately industrious, yoked to the capitalist work ethic, and, unlike Muslims, do not have self-pity. In terms borrowed from Max Weber, all Jews, Sikhs, and other Asians, are secret Protestants, incorporated within the European model and obsessed with work. ${ }^{44}$

The white bourgeoisie ideal in this position glorifies work within the European paradigm as the defining ontology, dividing humans into categories. Those outside this paradigm are seen as sub-humans, a view that reinforces the collective identity of the apparent human culture. Following this logic, they acculturate better into Wwestern societies and there are no real problems, while Muslims are the antithesis; they do not want to work and are parasites on the system funded by the taxes of other, diligent other people. There is an assertion of a wider belief that the European is the sovereign subject of the world. ${ }^{45}$ Underlying this rhetoric is a fear of the threat to this suzerainty, and an explanation for the increase in neo-Nazi behaviour and belief, and attention by the media. Fundamentally, the First World is no longer, 'positioned in the first person with regard to the Second or Third Worlds'. ${ }^{46}$ Journalists and media commentators have the First World rule without question, incapable of observing how the challenges of the world may relate.

Burchill is right to point out a relationship between the perceptions of immigration and increases in anti-Semitic attacks, but she is wrong to blame this on Muslim immigration. Everything comes down to problems with Muslims and their ontology. Quoting a 2013 study by the European Union Agency for Fundamental Rights, that found 64 per cent of German Jews avoid the public display of symbols that would identify them as Jewish, and only 28 per cent both report anti-Semitic incidents, Burchill blames this on Muslims, but she does so by offering no real evidence. Apparently, it is the way in which Muslims have moved into different countries, and do not work in them, that has made populations turn against anyone perceived as other, including Jews. Anti-Semitic attacks are blamed not on those carrying them out but on the Muslims. In a perverse logic, Muslims are the new neo-Nazis, with Muslim culture taking the West backwards; they are to be blamed for anti-Semitism, and they are the worst offenders. 
There was a point in the late 1970 s where people began to question this polarized rhetoric. The end of hardened truths worked against academics and popular writers, who made a name out of being polemical, those who claimed they knew the truth better than anyone else. How could you state one truth was better than another anymore, if since the late 1970s all truths were being challenged? But, in this (post)post-structuralist world, as typified by Burchill, it is as if an attempt to move from binary oppositions had not taken place. We are not simply back in the 1950s, where everything different is a threat to be condemned as evil from an ontological perspective. We are in a time where those who are demarked as assimilated and thought to be 'good others' are raised up as the antithesis of the evil that lurks waiting to steal jobs and women, threatening any semblance of peace. In this blinkered logic, one group is innately evil - and this racism is overlooked.

A Protestant work ethic is asserted, uniting certain groups with nationhood, while excluding others. Nations then construct the notion of greatness in the imagination, utilizing the media where they can. The British leader Theresa May's meeting with Scottish leader Nicola Sturgeon in March 2017 was one such construction. Even before the meeting, the media reported that May was asking Sturgeon to conceive of the United Kingdom as being 'great' again, without Europe but with England and Scotland staying together. Playing the game of greatness and nationalism is supposed to gain votes against Scottish independence. Behind all of this is an analogy of war and invasion, stressed to make sense of events, even when terrorists are home grown, such as the London attacker in March 2017.

The denunciation of a race of people as innately malign comes with a rewriting of history. More dangerously, there is the blurring of race and religion, so any cultural differences are completely blotted out. There is no scope for any thought that Muslim culture has brought anything of significance to the world, or will. This rhetoric has been highlighted here because it is common and unextreme, within general media discourse. This is the worst kind of biological racism and functions to enable one group of people to assert their superiority over another. Within this paradigm, which frequently predominates, immigrants are always Muslims, stealing 'our' jobs and all Muslims are sex offenders, attacking 'our' women. This conjuring of hatred and fear leads catastrophically to the dismantling of the enlightened values and freedoms that Jewish culture within this rhetoric instigates.

Regardless of the conflict between Jews in Israel and their Muslim neighbours in Palestine and the Gaza Strip, this rhetoric is promoted by groups who use it to reassert their connection with nationhood. This occurred 
during the referendum on the UK to leave the European Union in 2016, when many people from ethnic backgrounds voted for the UK to leave the EU, defiantly stating their allegiance to the island state and condemning migrants. For Burchill, politicians trying to win votes are supporting immigrants, and are going along with this apparent evil. Given the spate of Islamic attacks and the conditions of women in some Muslim cultures this is understandable, but it has been shown how popular culture, such as NSU German History X, allows for nuance. Who the victims are and who the perpetrators are at times is blurred, which is a far deeper approach. We shall return to how these media transformations are constructing discourse in Chapter 4. 


\section{Nazism, Neo-Nazism, and Comedy}

In the run up to the American presidential election in 2016 a whole raft of comedians mocked Donald Trump, but this did not damage his power base. Any transgression via satire and comedy could be used to reassert the status quo. Trump was no long considered a joke when he started to implement his policies. This chapter considers comedy, Nazism and neo-Nazism in film and media, with reference to theorists on transgression, such as Chris Jenks and Julia Kristeva, and novels and televisions shows that gained media attention. Taste is key to any discussion of comedy. SurfNazis Must Die (Peter George, 1987) is a prime example where all forms of taste are contested, both in terms of content and aesthetics. With laughable production values, ludicrous dialogue, and an insane plot, the film is wrong on many levels but still works. Set in a post-apocalyptic world, this is a comedy revenge story of black empowerment. Leroy's mama (Gail Neely) goes after the gang of neo-Nazis who have murdered her son. The film succeeds in indicating how absurd Nazi-related belief systems are, with the neo-Nazis doing Hitler salutes on surf boards.

Another excellent example is Look Who's Back, a comedy film directed by David Wnendt in 2015, based on the bestselling satirical novel of the same name by Timur Vermes. This could be criticized for being purely about controversy and entertainment. This implies there is something wrong with both of these categories, suggesting there always needs to be an educational value. Often the educational value of any work of art is in the interpretation. Vermes obviously felt a need to spell out that his novel was a work of fiction, given at the beginning he states that certain people have not met Hitler (played by Oliver Masucci in the film). This is part of the joke that feeds into the idea that there are actually various versions of Hitler. The underlying more serious point is that we all have Hitler within us, as does every nation. We just may not know it yet.

In Look Who's Back Hitler returns from the dead. In some sense we have all met Hitler, or we believe we have. This encounter with the various forms of Hitler or the Nazis takes different forms, whether it is: the comedy Hitler of American Mel Brooks; the British entertainer Freddy Starr; the partying Nazi of Britain's Prince Harry; the cool Hitler of David Bowie; or the depressed and lost Hitler of Bruno Ganz in Downfall (Oliver Hirschbiegel, 2004). Or even as a young man in Liverpool, as in Beryl Bainbridge's 1978 novel Young Adolf. We can all suggest ways on how to 'improve' Hitler, explicitly for comedy impact, if nothing else. Another paradox is that if we 
were to portray a Hitler, or to reenact an exact Hitler, returning from the dead as a saint, we would have to contend with the controversies around sainthood. For example, Mother Teresa and Pope John Paul II have both been accused of fascist activities, as has Pope Francis. Once again, we do need to be careful how we use the terms 'fascist' and 'neo-Nazi'.

From a novelist's perspective, the prose of Look Who's Back in the early stages could easily be attacked in terms of its style. For example, Hitler narrates, 'seeing as I did not drink', which is an obvious well-known fact, and 'I turned my head', the latter phrase being unnecessary. ${ }^{1}$ But the narrator here is Hitler himself. Being critical of Hitler for being bad at prose, or criticizing Vermes for not being particularly prosaic, or praising Vermes for making this deliberately bad to simulate Hitler's incompetence or awkwardness, would be inaccurate. This is, therefore, an excellent novelistic device to indicate Hitler's and our discombobulation. This may also be a problem with translation, from German into English. Plus, with the dictator suddenly appearing in the twenty-first century, after being dead for over 60 years, his language and point-of-view narration and sense of being is bound to appear strange.

Hitler sets this us up in his introduction with the point that this might be comic, as it was in the trenches, but there are paradoxes given the tragedy underlying Hitler's original impact. What is highlighted is that people will do anything to get ratings for a television show and are not in the slightest bit interested in truth. This in itself is not funny, original, or news, but what is interestingly controversial is how the overt racism becomes a spine within the novel. It is up to the reader to judge whether the author challenges this racism. Could the author be accused of attempting to gain cheap racist laughs, for example? This is debatable and might conceivably be judged to be verisimilitude, with racism still ubiquitous and increasing, especially concerning immigration and Islam. The Turks come under attack in this sense, especially in the laundry scene in both book and film. The Turks recognize him and 'cleanse' him, getting him ready for his performance on television. This implies that the leader of any state is always dependent on the underclass, even if it is a despised class that must be destroyed. Hitler's main motivation was not simply to destroy all Jews, but to bring down civilization. This could be described as a class war but even that is not going far enough. At every stage, given this is Hitler narrating, the author can hide behind the narrator.

If all we can perceive are mediated images then the conclusion must be that we do not own our consciousness - the media does. This moves us away from Bergson's view on the images constructed by our memory, and his 
arguments against realism and idealism, to a fusion with Jean Baudrillard's and Guy Debord's take on the world. ${ }^{2}$ Of course, the resurrected Hitler must learn about the world through whatever channels he can, including the television and the Internet. What he discovers is that most channels are not being used for 'propaganda', in his opinion, but for cooking shows. Hitler is correct in his judgement that these are gruesome and in many ways offensive. This is humorous, but it unwittingly ignores the wider point that these television shows are a form of propaganda by the state far subtler than anything Hitler imagined, hence capitalism has had a longer reign. The propaganda of capitalism has worked so well that most people, of the left and the right, find it inconceivable that any other system should exist.

Hitler believes television is the medium of the age, but this is where the novel in terms of the media and neo-Nazism appears already out of date, given everything is on YouTube. When Hitler starts shouting at the television, because he thinks it knows what he is doing, this is for pure comic impact, drawing on the clichés of the loud, bad and mad Führer. No acknowledgement is made of the technology that does already exist, such as Netflix, which actually follows exactly what you watch, and suggests shows to you, starting you at the point in the programme from where you left off, and so on. Hitler's assessment of the point we have reached is still enlightening. Why do these shows always have to repeat what they have told us, at length, as if we are morons, with the memory of a goldfish?

He has further comic insight into the Internet, especially Wikipedia, whose content, he quickly observes, can be made up as you go along - which has its advantages. We do not need a fascist dictator returned from the dead to tell us this, but for someone new to the Internet like this Hitler, this is interesting in terms of its potential for propaganda. In a fascist regime facts no longer matter, as people have continually pointed out with Donald Trump. When Hitler wastes three hours playing the game Minesweeper we all can empathize, as most people are aware of the addiction of games or new technologies. In this sense, it is maintained that it does not take long for someone from the past to adjust to the present, however deluded or mad they are. This is an interesting observation, implying Hitler returns from the dead with a childlike openness to the new, rather than a closed-off mind.

Hitler believes this 'programme' they are all talking about is his mission and programme for the German 'race', not just a television programme. Despite an ongoing emphasis on the rapid change in technology, Hitler existed less than 70 years before the action in this fiction. The war necessitated advancements in technology, such as the innovations of Alan Turing, 
which pioneered the modern computer. It is hard to conclude from this that Vermes is in any way promoting the notion that it was through the Nazis that technological developments were enhanced, although Hitler's knowledge of the actual war becomes a rather didactic history lesson for those ignorant of the facts. The argument here is that fiction can educate and warn people in a more interesting fashion than dry history books, offering the potential to counteract neo-Nazism.

The actual format of the narrative is not new. In the 1970-1971 UK television series Catweazle, an eleventh-century wizard accidentally travels through time to 1969. The technology is much harder to grasp, and believed to be magic, dealt with by the time traveller through incorporating modern language into his own mental framework, with words such as 'elec-trickery' and the 'telling bone'. Magic is paradoxically an essential element to Hitler's propaganda. He understands that these advancements in technology are due to the hard work of the German people and their amazing industry. They might metaphorically be miracles for Hitler, but they are also another example of the supernatural superiority of the German race.

The comedy is contemporary and comments on political positions and psychological states. Hitler's view on Angela Merkel as a mother figure, or at least his reading of the media's view being this, is one that many Germans when the book was first published and film released might acknowledge. Hitler here is the voice of the people. In reality, rather than being a steady presence, however, there is criticism and concern from German academics over her fickleness, as evidenced by her policies on nuclear power and immigration. ${ }^{3}$ This weakness could actually be a strength, given her ability to be flexible and make fast decisions. Hitler himself, in this novel at least, claims this is the primary duty of the Führer. You do not need the support of the Volk. All you need is the ability to make decisions. This logic has filtered into many industries, and is promoted as a sign of strength in a leader, despite the possibility of it leading to long-term, disastrous consequences. There are number of politicians of the contemporary period, such as George Osborne, the UK's Chancellor of the Exchequer from 2010 to 2016, who stuck to their decisions, no matter what, for the sake of ideology. From this perspective, we can view Merkel's position as being much more rational. Hitler in Look Who's Back is condemned for being mad, because people think he believes he is Hitler, but he actually is Hitler. Whether Hitler was mad or not is another question. In this fiction he is psychotic in his continued hatred for the Jews and anyone non-Aryan and in his obsessive mission. Whether a pathological hatred of the other is madness is arguable, as definitions of madness are cultural. 
The sensitivities over Nazism and Hitler are played out in the novel, when even the wearing of a uniform is in question, as if it is remarkable that you can get away with wearing a 'real' Nazi uniform. ${ }^{4}$ Hitler re-appears in the place he always was, suggesting he has never gone away. Whether Germany has taken decisions to bury its past, ignore its past, resist or change its past, or accept its past, all roads lead back to Hitler. Germany now leads Europe, so where would they have been without him?5 Given all the post-war support Germany received, one can make a perverse argument that Hitler's self-destruction led to their predominance within Europe, especially its economic leadership. In terms of the multiplicity of Hitler, he is in everyone.

Hitler in this fiction feels successful, given the number of Jews in Germany is now so low. Israel is positioned in the middle of the Arabs, which according to Hitler is great as it keeps them occupied. Having Hitler point out the absurdities of history and geo-politics is obviously contentious and dangerous, but it does emphasize the absurdity of many global situations. In this sense, while many who meet Hitler think he is a mad man, akin to those who think they are Napoleon or Cleopatra, his take on the current situation in Germany is enlightening. Who exactly is the mad one in this context? Rather than Hitler being mad, is it more accurate to pinpoint the insanity as being a group psychosis of the politicians and even wider madness of the general population of Europe who accept what they are told?

The English comedian Sacha Baron Cohen has frequently been criticized for mocking various nationalities, or even regions, such as the north of England. In the television show in Look Who's Back Hitler gets a part on stage following on from a man who mocks certain ethnicities and nationalities for cheap laughs. Full of irony, Hitler lambasts the man for using all sorts of clichés about foreigners, claiming these are serious issues which should not be debased for comic reasons. Translating humour is difficult. Baron Cohen's various incarnations, from the UK television show character Ali $\mathrm{G}$, to Borat Sagdiyev in the Oscar-nominated feature film Borat: Cultural Learnings of America for Make Benefit Glorious Nation of Kazakhstan (Larry Charles, 2006), to gay Austrian journalist Brüno Gehard, to Admiral General Aladeen, and Nobby Butcher, do not necessarily mock the region they are from, but those who encounter them, who are unaware he is in disguise.

The double-BAFTA-winning Da Ali G Show (2000 to 2004) is a pre-eminent example of this, which might be lost in translation. Ali G, using the mask of an Asian wide boy from Staines, actually mocks everyone around him, including politicians, who do not understand his real identity. Those in authority and part of the establishment are duped into believing they are becoming more authentic conversing with a person they assume is authentic, 
and the voice of the youth culture, when he is actually inauthentic. Part of the joke is that they take him seriously, even his most outrageous views. The controversial side to Ali $\mathrm{G}$ is that he can make homophobic comments that are framed as jokes, but people who are homophobic may actually see these remarks as supporting their homophobia.

Vermes' Hitler is in some sense the opposite. He is the real Hitler, mistaken for a fake, but he is so good at his performance that he really does unsettle people. For the programme makers in this fictional world he has re-invented comedy that is cutting edge and is not just about mocking other people. The amazing thing about this creation is that people might believe in him, not merely in his veracity through his authentic performances, but in his actual mission. And this is the nexus of the novel. He gains followers from different sectors in the community. History appears to have been forgotten or German guilt overcome, so that the so-called real German belief can come through. Placed in the context of Donald Trump's later victory, this should have been considered to be a prophetic warning. What this new Hitler does is offer authenticity, just as Trump claimed to do.

From 2009, during the period the book was written, there was a rise in neo-Nazism in Germany and across Europe. Because of the legacy of Nazism, the notion of closing borders and turning back refugees is far more contentious for Germany than most other countries. In 2017 Trump demonized the whole of Europe as being the zone of terrorism, where all acts of violence occurred. He falsely claimed European media did not report terrorist attacks, using this falsity to support his ban on people travelling to America from seven Muslim countries and refugees from Syria. Of course, the high number of people killed in America by white separatists is significant, but Trump's aim was to promote a climate of fear to justify building up the American military. In Germany immigration was also a central issue, but immigrants are not totally banned.

These sensitivities have an impact on the way the media operates. On 9 April 2016 Netflix began streaming the television adaptation of the novel Look Who's Back, but not in Germany or World War II territories or Germany's allies, including Austria, Japan, Slovakia, the Czech Republic, the Netherlands, Belgium, Luxembourg and Taiwan. An Italian version featuring Mussolini was developed. This had a wider implication in Italy, where Silvio Berlusconi has held a wide variety of senior political positions, including Prime Minister, for a total of nine years and been a member of the lower house for nineteen years. Unlike Merkel, his influence in Europe has not been felt to be benign and he is surrounded in controversy. Berlusconi is the nexus where politics and media unite, given he has the controlling 
shareholder of Mediaset, and was ranked by Forbes in 2009 as the twelfth most powerful man in the world.

All of this is far more transgressive in Germany. In other countries there has been a satirical genre mocking the Nazis and Hitler. In America, there was Mel Brooks' The Producers (1967). In the UK, there have been a variety of comedy programmes, such as Monty Python's Flying Circus, where in one sketch, broadcast 4 January 1970 , Mr. Hilter (sic) is staying in a bed and breakfast in England. Here it is the insanity of the English that is emphasized, with one couple arriving and the husband proceeding to describe their journey in excruciating detail. This is an accurate portrayal of how English people behave. The joke gets more intense when they are introduced to the other guests, including Mr. Hilter's table. The Germans are studying a map to fathom the logistics behind an invasion. The English man then proceeds to berate them for not travelling in the direction he suggests across England. This English male habit of always needing to be right, and always controlling the route, is what is fascist here and comic. Hilter is dressed in a Nazi uniform, as are his comrades, but there are no swastikas, and they are just trying to get on with their business. The whole absurdity of a bed and breakfast, where people are forced to be public whilst paying money for a private holiday, is also highlighted. As with Look Who's Back, the fascism and the insanity is obviously not that of Hitler or Mr Hilter but the contemporary society. In this instance, it is John Cleese who is playing Mr. Hilter/Hitler, to good effect.

The now classic Fawlty Towers episode 'Don't Mention the War!' (season 1, episode 6, aired on 24 October 1975) is another relevant sketch. Cleese already had a reputation for his comic long legs, and his Ministry of Silly Walks character (from Monty Python's Flying Circus) often used ridiculous Nazi goose-steps. As hotel manager Basil Fawlty he confronts a German family in his restaurant, all the while insisting to employee Polly (Connie Booth), 'Don't mention the war'. The more you ignore something the more it resurfaces, as a famous Austrian and contemporary of Hitler, Sigmund Freud, discovered. In a dazed and confused condition (having hit his head), Basil Fawlty takes the food order of the guests and reads it back to them, using the names of the Nazi hierarchy in the place of the dishes. One of the female guests bursts into tears while Fawlty launches into a full-blown Hitler imitation, with his finger under his nose and the crazy walk. The misunderstanding over 'who started it' - either the war or the argument in the dining room - turns into a 'we won the war' statement after Fawlty is stopped from telling a joke about a bomber headed for Berlin. Fawlty excuses his behaviour by claiming that he is just trying to cheer the crying 
woman up. This is confirmation to him that the Germans have no sense of humour. In 1978 the show was sold to 45 stations in seventeen countries and was the BBC's best-selling overseas program for that year.

Many other comedians have utilized Hitler in a variety of comedy sketches. For example, there is the Armstrong and Miller Show sketch (in season 3, episode 5) about Hitler, where classified information concerning the Nazis is phoned through from Germany to London. A man who has been constructing bawdy songs in a bar to boost troop morale is then handed the 'facts': 'Hitler has only got one ball, Goering has two, but small; Himmler, has something similar, but poor old Goebbels has no ball at all.' His previous songs, such as, 'Goering's piss is filled with diseases, that's why he has to piss with tweezers,' have been conjecture, but now they have the 'facts'. With this it is apparently game over for the Germans. 'Gentleman, I think we have won ourselves a war'. The Nazis then sing, 'Churchill has a large cock', but then question whether this is meant as a compliment or not, at first thinking this is an insult.

Just as Shakespeare used a disability based on an alleged fact to construct Richard III's character, disability is equated with not just moral weakness but evil. The obsession with Hitler's balls has not dissipated. Hitler's medical records appeared for auction in Bavaria in 2010, but were swiftly confiscated by the Bavarian government. It took until 2015 before Professor Peter Fleischmann of the University of Erlangen-Nuremberg became the first person to analyse them. What he discovered was that Hitler suffered from right-side cryptorchidism, that is, an undescended right testicle. ${ }^{6}$ The medical report dated to 1923, following Hitler's failed Beer Hall Putsch. This seemed to contradict the report and evidence given in 1943 by Hitler's childhood doctor, when he was interrogated by the Americans and informed them that Hitler's genitals were normal. The obsession with Hitler's balls is overtly comic in itself, and underlying it is the notion that a 'monster', like Richard III, should have some form of disability.

Comedy can function specifically as a form of nostalgia, asserting that the past was always better than the present, a key theme of many rightwing movements, such as UKIP. The British television sitcom 'Allo 'Allo! (1982-1992) epitomizes the use of nostalgia. Staring Gorden Kaye and set in a café in German-occupied France, it primarily uses farce, fake accents and sexual innuendo for its comedy. There is an overarching narrative to the whole programme concerning stolen art (The Fallen Madonna with the Big Boobies), but the following tagline neatly sums up the whole series. 'Meet René, the most wanted man in Occupied France. Women want his body. The Resistance want his brain. And the Nazis want his sausage.' Sex 
dominates everything. In season 1, episode 8, when René's wife catches him with another woman, he explains that he is teaching her martial arts to stop her being ravished by the Germans. The Nazis are made to look ludicrously old fashioned and pedantic.

By 2009, Downfall (2004), referred to in Look Who's Back, had become one of the top 25 films parodied on YouTube. These parodies included Hitler ranting because a pizza was late, because Oasis had split up, and due to a parking problem in Tel Aviv. There is always a question over the purpose of comedy in this context. For Daniel Gross the problem with most contemporary Nazi comedies is that they are humorous, but nothing more. ${ }^{7}$ Charlie Chaplin made The Great Dictator in 1940, but writing in his autobiography in 1964 he claimed if he had known of the concentration camps he could not have made the film. There are deep questions concerning using this topic for comedy but these various forms of Hitler mock both Hitler and his ideology, functioning as satire and often serving a political purpose. Rather than hit out at the YouTube parodies, the producers of Downfall went on to make the film version of Look Who's Back where Hitler indeed becomes a YouTube star. The climax is when it is realized that Hitler is not a 'real' comedian but the 'real' Hitler. When a TV producer wants to murder him, Hitler comments that it is impossible to get rid of him, as he is part of everyone. This is not mere sophistry or postmodernism but fact. Hitler is not merely a character stemming from the imagination.

Germany defines itself in opposition to Hitler, given every time 'Hitler dies on a movie screen, every time he's reduced to a pathetic and bumbling fool, society reasserts its loathing for Nazism. ${ }^{8}$ It is the parodies on YouTube of Downfall that have been seen by millions of viewers, not the film. For Gross, when these comedies work they enable audiences to understand the past and reinterpret the present, which helps them see injustice, but on the other hand they can just 'allow' viewers to look away. This tends to come back to the purpose of art, briefly discussed in the opening of this chapter. Nazis are sometimes innately humorous, especially Hitler with his weird moustache, tightly wound persona, and rages, an element John Cleese in particular has played with. It does seem wrong that we should laugh at all in the context of 6 million Jews being killed by the Nazis, but is this laughter enabling us to look away?

Freud maintained that laughter was fear appeased; we laugh when someone slips on a banana skin, but it is out of relief that they have not cracked their skull open. The very act of laughter in these circumstances can be a form of transgression, which inevitability reinforces boundaries. In this context, mocking Hitler may actually reassert the status quo, and is not 
transgressive or subversively political at all. Transgression then is not the same as total disorder. A border may be crossed, but ultimately it reasserts order, and it is concerned with the limits. Within this mythology, Hitler is a figure who can be mocked in all sorts of ways, to reassert the social order. What is actually being mocked is not Hitler or Nazism or the Jews. What is being mocked is the notion of the absolute 'other', that which is also in the German people, and is actually the same as the German people.

To admit this is difficult, however. As Julia Kristeva has explained, it has taken one of the history's most famous Jewish inventions, psychoanalysis, to help us detect the foreignness in ourselves. ${ }^{9}$ Furthermore, as with concepts of pure evil, to split this off, to place this elsewhere, is to place this nowhere, but lends it omniscient power. Kristeva coined 'the abject' by an analogy with 'subject' (sujet) and 'object' (objet), from the same Latin root (jectum, from iacere, meaning 'to throw'). The abject is that which is 'thrown away', or 'cast aside' from conscious perception, neither a perceiving subject nor a perceived object, and it is a third state: the shadow of images of the sublime.

When discussing Nazism and the media it is appropriate to explain what evil may consist of. Despite utilizing the interior monologue of the novel as a voice-over, the film version of Look Who's Back has as its primary focus the character Sawatzki (Fabian Busch). This character, whose name is close to swastika, is the first person connected to the media to discover Hitler (Oliver Masucci). Sacked from his television job as a freelance documentary maker, at home with his mother, he is going through footage connected to a documentary he is making about soccer in an apparently rundown area of Berlin. During this review of his footage he spots Hitler talking to the children playing football, and so the real story begins. These might be difficult times in Germany, with many people unemployed, including those connected with the media. It is through Hitler that Sawatzki, at least, gets his job back. He is like the 'little man', who appears in many comedies, from those of Harold Lloyd to Charlie Chaplin, to Woody Allen and Simon Pegg. The thesis is if such as loser can succeed then anyone can, plus it is funny seeing him fail, and sometimes overcome the odds.

In the film, Hitler and Sawatzki tour the country to meet the people, with Hitler doing a number of outrageous stunts, such as shooting a pet dog who will not leave him alone and kicking the lights in of Sawatzki's mother's car. Back on the road Hitler has the dead dog with him, using it as a type of ventriloquist doll to macabre comic effect. They also come across football fans who appear to love him, many wanting 'selfies' taken with him. On the tour as a whole many people speak to Hitler and say that Germany has 'gone to the dogs', and that they need someone like him, a strong leader. Hitler 
then is controlling the people as he controls the mouth of the dead dog. The film has Hitler as more of a Borat figure, given it is in some ways harder to show his inner life, and he does speak with more people, ascertaining their views while campaigning.

The novel reveals more of the inner life of Hitler, and shows he does have a human side. Around Christmas time he states he does regret not having a family and he thinks of others he knew in his command that had families, and how important it is to have a representative of the people in your inner circle. At the same time, Hitler admits there are sacrifices that need to be made, and this festival period is a good time for him to read and plan out buildings. The clear point is made in the novel that it does not matter what this comic Hitler says anyway, because people will report what they like. Whether this is a condemnation of the press and the media is unclear. In an interview with Bild the journalist condemns him, and edits his responses, but this only draws more attention to him..$^{10}$ The publication in this instance has a mission to bring reconciliation between the Germans and the Jews. The television show Hitler works for is only worried about is ratings. Despite how offensive his comments might be perceived to be, overall most of those working with the television channel are pleased, given this draws more attention to him, and works as free publicity. In this sense, the more offensive he is the better.

\section{Conclusions - Comedy and Politics}

Comedy occurs unintentionally during serious television programmes, and public mockery can have impact. When the BBC decided to allow the head of the British National Party onto their flagship politics television show Question Time in 2009, many questioned the efficacy of allowing this. A strange form of comedy entered the show, which took place under heated circumstances, with employees of the BBC unable to leave the building given the strength of the protest against Griffin outside the building. In 2016 if another figure arose like Griffin it is hard to believe this would be allowed, given the voice of those opposing freedom of speech is so strong. Jack Straw, Sayeeda Warsi, Chris Huhne, and Bonnie Greer, all appeared along with Nick Griffin. Jack Straw, a Jewish Labour politician, had stirred controversy by stating in 2006 that the Muslim veil was oppressive, and later by his comment in 2011 that Pakistani men see white females as 'easy meat'. In 2015, Straw was exposed by Channel 4's programme Dispatches, and The Telegraph, as being willing to take cash for 'offering services' in parliament. 
Similarly, Baroness Warsi, at the time of the Question Time debate Shadow Minister for Community Cohesion, broke the ministerial code multiple times, and numerous controversies over expenses have dogged her. In 2013 Chris Huhne, also on the panel, was sentenced to eight months for perverting the course of justice.

Other than Bonnie Greer, everyone on the panel has since fallen from grace, so the moral high ground of the panel needs questioning. Other than some form of schadenfreude, this is not especially comic, but the point of the show was to expose Griffin for who he was and to make a mockery of him. The claim was that he was racist, so the idea was to show him for what he was, and then make him and his party a laughing stock. On Question Time Griffin declared his own father served in the RAF, fighting against the Nazis, so by implication he is not a Nazi, and then attacked Straw personally for his father not fighting against Nazis. All of this stemmed from a question around Churchill, and Griffin uses this to claim Churchill was anti-immigration, and indeed the nationalism expressed through the wars was evidence of this. The first black member of the audience to have a voice calls Griffin disgusting and challenges Griffin to admit that people from ethnic minorities bring something to Britain. Griffin then claims he is continually misquoted in the media, so if you perceive him as a monster this would be understandable, if you believe what they say. The host challenges Griffin, asking him to state which quotes about him are inaccurate. 'Are you a Holocaust denier?,' he asks. His response is that he did not have a conviction for this, and a member of the audience laughs. 'Why are you smiling?' Dimbleby asks Griffin, 'It's not particularly funny.' It might be concluded the audience member is laughing at the audacity of Griffin, and his attempt to deflect the question with Griffin just continuing this 'comedy'. His response is then to state the Holocaust is used and abused in arguments about immigration.

A number of his own quotes are read out to him, such as, 'I want to see Britain to become 99 per cent genetically white, just as she was eleven years before I was born.' In July 2014, Griffin stepped down and was replaced by former teacher Adam Walker. A major period of success for the party was 2008, when the BNP held 50 local council seats, won a seat in the London Assembly, and Griffin and Andrew Brons were elected as Members of the European Parliament. In the 2015 election the party stood eight candidates, a reduction of 330 from 2010, receiving less than two thousand votes. They were then a joke party at this stage, and not a serious threat. It was wrongly assumed the threat of the far right has dissipated. Despite Britain's First popularity through social media, UKIP appeared as the mainstream alternative, Farage flirting with all manner of racist discourse. 
Within two years the leader of the main anti-immigrant party in the UK was now the first political figure to meet the newly elected president, Donald Trump. While the media and popular culture mocked figures such as Nick Griffin, right-wing leaders such as Donald Trump were gaining support from movements headed by people such as Nigel Farage. Politicians and the media did not actually take Trump seriously enough, given his unexpected victory. In a spoof infomercial on Saturday Night Live, 'Racists for Trump', a woman is ironing, commenting she likes Trump because he is authentic. Only later do we see she is ironing a KKK gown. A young man states his support for Trump is due to the economy, which he indicates will grow under Trump by raising his arm, revealing a Nazi armband. Despite the mockery, this did not prevent Trump taking power on 20 January 2017, and immediately setting a new agenda of global disharmony.

Trump's spat with Alec Baldwin for his impression of him on Saturday Night Live is an obvious example of how comedy can antagonize. Whilst victimizing Muslims, immigrants, and other people who might be considered 'others', including those who are lesbian and gay, and those who are women, Trump has reinstated himself as a victim. The Nazis turned the whole of Germany into a victim, desperate for revenge. Trump himself is never caught on camera laughing. This lack of an ability to laugh at himself reveals how deeply serious he takes his image as do his allies, for whom image is everything. Steve Bannon as Trump's chief media manipulator in the White House until August 2017 closely choreographs this, a subject we turn to next. 



\section{Necrospectives and Media Transformations}

\section{Myth and History}

Going beyond representation, we now examine Nazism and neo-Nazism and the media with regards to Hegel, Baudrillard, Bergson, and Levinas. Questions over authenticity, the disappearance of meaning, history and truth, are evaluated. There is an examination of postmodernism and irrationality and the rise of the right and Donald Trump, and how engaging with neo-Nazism rhetoric has been used to galvanize support for the right. We also realize how the neo-Nazi position is akin to mainstream business practices. There is an explanation of how the media reporting on events eliminates meaning from them with the persistence emphasis on the next event. With reference to postmodernism, how authentic this engagement with neo-Nazism is will be outlined.

For Hegel, history does not have the immediate existence of art. ${ }^{1}$ The narrative of representation, such as media images, has more veracity, regardless of accuracy, when compared with historical 'truth'. Hegel took the metanarrative approach to the extreme, writing that art 'brings before us eternal powers that hold dominion in history, without any such superficiality in the way of immediate sensuous presentation and its unstable semblances'. ${ }^{2}$ While there might be something higher than art, such as philosophical thought, and religious or moral principles, art points beyond itself, making it superior. Hegel continues to emphasize the importance of the sensuous form in art, typically promoting Greek art over anything else, but there is the caveat that this is only the partial truth. When it comes to God, this is an eternal Spirit which German writers like Goethe, whom Hegel knew well, linked to the spirit of the country.

As with Nazism and neo-Nazism, Hegel and Goethe battled with the notion of the rise and fall of culture and cultures. Hegel's art criticism essentially argues that it was only during a period of decline in the aesthetic qualities of art that good reflection and criticism could take place. Seeing as this period was the birth of German criticism, ipso facto, the art was substandard according to those involved in the criticism, such as Hegel. In the German Nazi state these insights needed to be rewritten. Hitler needed to overcome any doubt about the quality of German art and rewrite history appropriately. But history does not have to be rewritten if the gaze can be 
averted, which in 1940 s Berlin it was. Over 70 years on, some of the more right-wing commentators during the 2016 presidential race in America praised Trump for his propaganda and his ability to bring theatre into his campaign. Condemned in some quarters as a modern-day snake oil salesman, in others Trump was praised as refreshing. Following Nietzsche, the carnival of festivities was materialized through cruelty, so this form of entertainment becomes the paramount centre of pleasure, and the more violent the better. Christopher Lasch in The Culture of Narcissism had placed street protests within this paradigm, condemning them as theatre.

For Jean Baudrillard this return is perverse, given it is an obsessive attempt of the present to put the balance straight by returning to the past. Writing towards the end of the twentieth century, he saw the obsession with the Holocaust as part of a general drift towards a revival of an interest in fascism, in Nazism, and in extermination. ${ }^{3}$ We are indifferent to the present and to our own condition, leading us to continually rethink the past, the process known as necrospective. Everything has disappeared, so there is a constant returning to the past. This antithetical stance appears liberal and non-dogmatic, but can come across as apolitical, and divorced from humanity. There is an insufficient amount of everything, including history and philosophy, and this leads to the conclusion that there is no point trying to find out any more about the Holocaust, or any other atrocity.

The underlying view that it is the media that governs moral conscience contains some truth. Just as Nazism and neo-Nazism is concerned with the delineation of boundaries, the media functions as the delineation of moral boundaries. From approximately the early 1980s when definitive history and truth was being exploded by critics such as Derrida and Baudrillard, an alternative history was being developed, often based on fictional sources, such as The Turner Diaries. This neo-Nazi text became a blueprint, revealing a world where a final battle occurs between the races and the white race wins. The neo-Nazi movement seized on this text as an idealized projection of the future, already written. Science fiction then becomes a form of writing history from the point of view of the survivors, those here with Aryan blood considered to be the strongest. The dominance of the image creates a form of amnesia and there is an entry into the mythic stage, away from history. Here history and projects of the future are idealized fictional zones. Neo-Nazi movements have used this media form, the novel, as a religious and historical text. Importantly, given the void of meaning and telos from history, it is only the novel that is able to depict human consciousness and society. ${ }^{4}$

A question is raised over trying to understand events like the Holocaust because, 'basic notions as responsibility, objective causes, or the meaning 
of history (or lack thereof) have disappeared, or are in the process of disappearing'. It should now seem obvious why this is. Moral or social conscience is a phenomenon 'governed by the media. ${ }^{6}$ Writing in a time before Twitter, Baudrillard is referring to the legacy of mainstream media controlled by large corporations, the government, or both. He declares that Nazism and the concentration camps are even more unintelligible now because of their reworking in the media. The image has removed their veracity completely, functioning as part of our amnesia. He suggests that it is now possible and legitimate to ask, 'Did all those things really exist?' ${ }^{7}$ This is precisely because of the proliferation of their images in the media. This is not the same as confirming their immateriality. He admits this question is 'an intolerable one', but the point is to ask and examine what makes this impossible logic possible. The media replaces, 'any event, any idea, any history, with any other'. ${ }^{8}$ This scrambling of specifics, this transferring of the present with any past, demolishes both. His point that a full and detailed study of the facts nullifies events and history, making them cease to have existed, gives too much weight to the researcher's endeavours. They may continually delve into the entrails of history, finding certain new truths, but they are not destroying history, as Baudrillard claims.

Post-Auschwitz, when explanations are hard to find, there is a movement from the historical to the mythical. And this mythical is media-led, with one tweet creating a mirage. The mythical and reality merge. The frenzy of the media is explained using the language of nature, sport, and nutrition, such as 'Twitter storm' and 'click bait'. There is an attempt to turn the fantasy and myth into the natural. With the Holocaust and other crimes in order for them to become a myth, 'historical reality must be eradicated'. ${ }^{9}$ Baudrillard is implying we now have entered a world where violence and reality are not manageable, so this is merely positioned onto the past, forging a loss of reality, 'which is now our reality [sic]..$^{10}$ This logic may give pseudo substance to neo-Nazi arguments. Those condemning postmodern wrongly misinterpret Baudrillard in the same manner. Pushed to its final conclusion, the summary would be: 'We ourselves no longer exist sufficiently even to sustain a memory, and that hallucinations are the only way we have left to feel alive. ${ }^{\prime \prime}$ What then are these hallucinations exactly? For neo-Nazis, they are perhaps the absolute belief in a Zionist conspiracy, which then feeds their desire for revenge. Baudrillard's discourse can be viewed as a form of hallucination, which has been seductive.

If we want to define certain texts as neo-Nazi or Holocaust texts, it is important to remember that classifying work this way as generic is limiting for, 'genres are agents of ideological closure - they limit the meaning-potential 
of a given text'. ${ }^{12}$ Typically, the more generic a text the more meaning will be limited. The text is nothing without an audience and critic, so the way media is branded is important. As with Noel Carroll's arguments on the horror film, some of these forms of media have an appeal and are popular due to a form of 'repulsion' and 'disgust', matched by a form of 'pleasure'. While it might at first appear perverse to claim there is a form of 'pleasure', despite the millions of deaths we know the ending is a 'happy' one. Good triumphs over evil. In some degree, the Nazis were defeated, even though neo-Nazism continues, and there is still a subtler triumph. The tropes of the horror genre are applicable here. If we do not brand the Holocaust film or elements connected to neo-Nazism as genres in themselves, but see this as part of the horror genre, then Carroll is still relevant. Carroll's views on genre have a synergy with Baudrillard's work. The audience of horror is seeking that which it would seem natural to avoid. But this engagement might explain why what formerly is natural and unnatural has now merged.

Can the echoes of Nazism through popular culture create its own brand of neo-Nazism? Like all totalitarian ideologies and all religions, Nazism sought to position itself 'higher' than family ties. Any successful religion or state must coexist with the family, whilst containing it. Nazism can be viewed as just an extension of Christianity, which in turn has its origins in a splinter group of Judaism. For Eric Voeglin, there is a millennial prophecy underlying Hitler's discourse, and this was, 'mediated in Germany through the Anabaptist wing of the Reformation and through the Johannine Christianity of Fichte, Hegel and Schelling'. ${ }^{13}$ The Nazi belief in a 'superman' is part of the trajectory that stems from the English Reformation mystics, and their promotion of the 'godded man'. Nazism was in this paradigm a resurrection of Gnosticism. What formed the Nazi ideology was faith in the End, shaped by Christianity, which required a final battle between good and evil. ${ }^{14}$ Each age has its version of this battle, with the media latching on to this apocalyptic discourse to maximize the drama. This was startlingly clear in the 2016 Clinton versus Trump presidential campaign, when both sides strategically pushed the point that this could be the end of times. In every month of his presidency Trump has pushed this rhetoric further, in August 2017 threatening war with North Korea.

This profound belief in the End is reflected in Freud's growing conception of the death drive, which had a significant impact on philosophy. Freud had moved out of Nazi occupied Austria due to the destruction of the Nazis. The final stages of Freud's life are intimately linked to how Nazism has come to be recognized globally and then mediated. The countless biographies of Freud explain how he was able to escape persecution due to his connections 
and wealth, offering another interpretation of Nazi persecution. Almost 30 years before Freud moved from Vienna to London, he published his essay on the uncanny, 'Das Unheimliche' (1919). This opened up the gates to the questioning of what is real and the notion of a bifurcation between the feelings of being at home and not at home. It has been the primary essay for discourse on the gothic within literary and cultural criticism ever since. Nazism and the Holocaust can be interpreted as part of this, given they haunt texts and often provide the backstory. There has been a resurgence of neo-Nazi ideology and this concerns the related issues of identity and rootlessness. Historically, within the Old Testament, there had always been part of this playing with the notion of the home within the Jewish tradition. Nazism and neo-Nazism deified the homeland.

History, theology, anthropology and philosophy overlap with narrative theory. This narrative can be regarded as a key narrative of history, where traditionally there is exposition, development, the complication (ghosts, for example), climax, resolution, and verisimilitude. When it comes to the paranormal, issues can never be finally resolved beyond the narrative and if beyond genre they are never resolved. The question of the Holocaust, in representation or in fact, sits within this framework. Historically, in the modern age, Nazis and neo-Nazis have been the monsters, normally the absolute evil, continually reworked in media and culture. For the Nazis, the Jews were in abstract the 'specter of evil' with German anti-Semitism having an 'hallucinatory image of the Jews'. ${ }^{5}$

Any event past, present and future, in this discourse, is merely representation. Baudrillard was not the first person to state this; he followed Greek philosophers, Middle Eastern mystics, and Guy Debord, who in 1968 claimed that everything that is directly lived has now moved into representation. Given the overwhelming dominance of the media, Baudrillard was probably the first prolific writer on the subject to witness this position most fully realized. For Debord, the subservience to the society of the spectacle leads to the disappearance of personality with authentic experience removed. ${ }^{16}$ Under this regime of the spectacle historical knowledge is exterminated.

Seeking explanations is one way of dealing with the Holocaust, and seeking to rid the earth of neo-Nazism is another way of redressing the past. However, as with genre, this linear approach may not be correct because it is a false way of containing the uncontainable. Gilles Deleuze's term the rhizomatic is of use here. For Deleuze, the rhizomatic concerns the non-linear, nomadic and anarchic. Just as today we are haunted by images contained in social media that continually disappear and then reappear, the Holocaust and Nazi iconography does the same, being part 
of the rhizomatic. Some artists, such as Francis Bacon, incorporated this iconography, using a layered system of artistic media, via combined images such as historic photographic stills merging with Nazi iconography, copied and overlapped through painting. Past, present and future fuses, and original non-identifiable meaning is created, moving outside the structures of genre. A haunting occurs and reoccurs with this methodology akin to the uncanny. What is now significant is how the mainstream has merged and moved beyond, without being beyond the mainstream, the normal with the paranormal.

Despite a call for clarity, these forms better portray the current condition, where the unconscious is made up of a variety of elements. There is a question concerning the return to the scene, a question that Baudrillard raises repeatedly. ${ }^{17}$ What are we looking at, as such, and why this frequent return? In this view, everything has disappeared, and that is the reason we keep looking. What of the suggestion that nothing has been depicted in the first place? There is a further complexity here, when we consider what the past and what memory might be. There are two levels, according to Bergson. The past is memory and the unfolding of time, and then we have the 'ideal past', which is formulating part of the 'paradox of Being'. ${ }^{18}$ There is a continual dialectic between an examination of the image and discourse on memory.

The actual is always present for Bergson but the present changes or passes. We can always say that it becomes past when it no longer is, when a new present replaces it. But this is meaningless. It is necessary for it to pass on for the new present to arrive, and it is necessary for it to pass at the same time, as it is present, at the moment it is the present. The image has to be present and past, still present and already past, concurrently. If it was not already past at the same time as present, the present would never pass on. The past does not follow the present that is no longer; it coexists with the present that was. If the media is the moral conscience of the people, there is amnesia with and from the image, and a movement from the historical to the mythic stage. In this mythic stage, neo-Nazism perpetuates the myth of the necessity of violence, but this is no different to perpetuating the myth that Western society always needs conflict and wars to thrive. Whether the representations are violent or not, the form may contain or portray violence.

There is a danger that the representation is then reality and even forms morality and conscience. Neo-Nazism consists of a celebration of violence against the other, and the media itself works violently. There is violence represented in and through the medium; media adds violence to violent culture not by content but by, 'the very fact of their facticity. ${ }^{19}$ This suggests the frenzy of the visible, where the form of the media itself is violent. This 
argument is exaggerated, because there is an overuse of the term 'violent'. Just because new technology might break away or rupture from the past, creating a fissure or wound, this assumes a teleological and linear progression. For film such a breaking with the past, aesthetically, is not a linear trajectory, given the complexity concerning continually reworking styles and tropes. Moving back to hauntology, this is resurrecting the ghost. There is a rhizomatic occurrence, where tributaries concerning technology move backwards and forwards, future ages reifying the past, seeking to use the technological medium of the past assuming an authenticity. Like film, memory condenses, simplifies and magnifies, and cannot be present in its entirety. Essentially, meaning in terms of film and memory is subordinated to feeling but memory is more real than the present, in that the present is always filtered through memory. Memory is a construction of the present, constructed by the present throughout the changing present, for consciously there is no such thing as anything but the present. Bergson argued that the past dominates all the present, so there is no such thing as a pure perception. We may have more of a concrete grasp on reality the more we are aware of these past images.

There is simultaneously a seeking after 'truth' and 'reality', and 'authenticity' through technological developments, matched by a desire for 'authenticity', by getting back to 'primitive' filmmaking, such as the Dogme 95 movement. Murder scenes are arguably, 'the most powerful and efficient vehicle for getting to the crux of film aesthetics. ${ }^{20}$ This is because they reveal the workings of the film; deadly 'violence' is then a metaphor for montage. Placing 'violence' in brackets is appropriate, because what 'violence' is here can be contested. The 'murder scene becomes a site through which filmmakers reflect on cinema as a set of formal components'. ${ }^{21}$ To maintain the manipulation of film images is absolutely violent is arguable and always contentious. Repeated enough, what is initially a mild metaphor, such as manipulation, is constructed as something extreme, such as violence. With regards to the Holocaust, if the scene of mass murder is never framed at all, and never allowed to be represented, continuing the violence metaphor, this is hardly non-violent in itself. Crucially, this can be conceived, historically and metaphorically, as a vast long take, with gaps in the montage, a film form which is a specific style for which there is no language. This is our morality and conscience, hence the frequent repetition throughout history. A large gap like this, the non-depiction of the gas chambers, for example, allows for the imagination to come into play, but also for it to be obliterated.

In Son of Saul, discussed in Chapter 2, the chamber door is shut by the protagonist, and we are placed in the position of the unwitting next victims, 
but the camera always draws attention to the survivor, not the victim. With an emphasis on the image, paradoxically, there is the pre-occupation with the nexus of the real. As Hal Foster argued, there is a return to the 'real' subject, in opposition to the excessive emphasis placed in the 1980 os on the textual modes of culture, or conventional notions of realism. ${ }^{22}$ This cultural dissatisfaction is expressed as a return to the shocked subjectivity of a traumatized subject. This is where the Holocaust is relevant. The results of the trauma embody actualized catastrophe and emerge as a revived cultural paradigm. The paradox here is that the white power movements and neo-Nazis argue they are the wounded culture. The obsession with the obscene takes the negative form of the cult of the wounded, diseased, traumatized bodies.

The vast machinery of the Holocaust, which still primarily lays nonvisualized, within a perpetual mode of denial, was then followed in the decades since by a transformation in the news media. Documentaries such as The Sorrow and the Pity (Marcel Ophuls, 1971) have taken an objective stance to the position of statesmen, resistance fighters, and collaborators. A proliferation of images and 24-hour news has not led to a deeper understanding of global conditions, or even a greater compassion. Despite the theoretical means to depict all-out war, and its devastation, what has occurred is a sanitization of war. The more images that are produced, in whatever form, the less they are seen, with the image supplanting reality. Stock footage is often repeated, like a mantra, offering no further understanding in any form.

Aerial bombardments are invariably shot from a distance, always reflecting back aesthetically to fiction films, such as Apocalypse Now (Francis Ford Coppola, 1979), leading to a position where fact and fiction blur. In the fictional forms, such as Coppola's film, there is actually more veracity, with soldiers on the ground facing the explosions, in a number of ironic ways. Rather than photography and the media leading to awareness, therefore, following Baudrillard, it obliterates the existence of reality. Occasionally, when a child is pulled from a collapsed hospital or dies on a beach, their face makes the front pages of newspapers, generating a frenzied storm on all media platforms, until the next event. The focus on the one is supposed to highlight the position of the many, as in the numerous film narratives that focus on the singular protagonist. This inevitably impacts on how populations perceive mass violence. In screenwriting terminology, the protagonist is the one that suffers the most, experiencing the most agony. If the evidence is placed on the one the many are ignored. This is not just the fault of traditional narratives, but of the news media. The natural 
progression is to suggest that the one can represent the many. This is how audiences relate to a story and how audiences have been initially educated.

The police and governments drive the notion that destruction is inevitable and unpreventable. This is unwittingly following a tenet that has strong similarities to Baudrillard's belief in the inevitability of evil. Fatalism and a certain predetermination enter the discourse. This is not merely so the authorities can avoid culpability if any event of mass violence occurs, such as a white-power terrorist attack. It has the added social control benefit of allowing extensive freedoms to be drastically curtailed, giving leverage for surveillance to be increased, while offering support for increasing security budgets, boosting the profits of the military and industrial complex. The police frequently move into such industries. Here, in stark summary, is the nexus of the contemporary position, where this theatre of cruelty is not prevented but ostensibly revelled in, staying true to Nietzschean discourse. Here theatre of cruelty is not referring specifically to the work of Antonin Artaud, Jean Genet, Jerzy Grotowski, and Peter Brook, but something far broader and insidious concerning global politics and economics.

The essence of the global media, within this lens, has performed what the Nazis only dreamt of. This discourse maintains the only way to attract the attention of the general populace and to create drama is to perpetuate this theatre of cruelty, or an apocalyptic worst-case scenario. With the rise of Donald Trump in 2016, children, and some adults, believed World War III was imminent and neither side in the presidential race did anything to reduce their fears. This then produces a profound level of conformity, in an attempt to control behaviour, and enables policies to be enforced. Without this theatre there is no wider interest in events. To vanquish violence would remove the audience's interest which is the means to control the audience. People may attempt to switch off, but in reality, the human race is now at a stage beyond this position of withdrawal. Only the minority remain beyond this position. Mobile devices and other methods have become fused with the living physical body, making the transfer of violent images and dominant discourse on violence cellular and biological. Biological and non-biological elements have fused. Arguing there is artificial or false memory produced by images, as juxtaposed with real memory, is inaccurate.

There was a serious attempt to record at least the impact of the Nazi ideology, which would counteract deniers and neo-Nazis proclaiming any denial discourse. Sidney Bernstein wanted to create a documentary that would contain solid evidence of Nazi atrocities, gaining the help of Alfred Hitchcock, and also approaching Hollywood director Billy Wilder, an Austrian refugee from the Nazis. Even straight after the liberation, 
film-makers realized that attempts would be made to deny the horrors that had been carried out by the Nazis. After 70 years, the film was restored and completed, directed by André Singer, entitled Holocaust: Night Will Fall (2014). Apart from documentary films, such as Hitchcock's on the Holocaust, which was felt to be too hard hitting just after the victory over the Nazis, there were no detailed documentaries. In this sense, the theatre of cruelty was not overtly carried out concerning the actual Holocaust.

With the continual reworking of the Holocaust in later documentaries Baudrillard takes on a striking relevance. The masses, according to this logic, feel a posthumous emotion about these events, 'which will make them spill into forgetting with a kind of good aesthetic conscience of the catastrophe. ${ }^{23}$ What is noteworthy here is the bind between understanding, which must always be limited, and systems of recording, montage, and editing, which will be also always be limited. The Holocaust becomes a documented event, via various methods such as television, but the television does not work as a deterrent to later similar occurrences. Indeed, with augmented reality, including now common headsets linked to videogames, virtual participation in violence is normalized. The apparent loss of authenticity is at the heart of this discourse.

A return to the real is always part of this agenda, and this is where the extreme right fuses politically with the extreme left. They are manifesting their differences by proclaiming they are authentic and true. This is perpetually played out ever since the real event of the Holocaust, with various overlapping acts of violence, differing in scale but often reflecting back to this period. The iconography of the Nazis is transferred onto a variety of national and international groups, each with their own local differences and variations. They may have local differences, but each has the sole aim of ridding the earth of what is perceived to be the racially inferior, bringing back what is felt to be authenticity. This functions in a pseudo-religious fashion, as a form of sacrifice, which leads on to the influence of the occult on Nazis and neo-Nazis. Myths have grown up over the Nazi interest in the occult and the supernatural, which again relates to the notion of the predetermined. There is hard evidence of the Nazis investigating aspects of witchcraft, not from the position of persecuting people supposedly involved in such practices, but the opposite. ${ }^{24}$

Heinrich Himmler had established an SS unit that explicitly investigated the history of witch trials in Germany, which were far more numerous than in other areas of Europe. ${ }^{25}$ The Nazi interest in the occult explicitly fed back to the work of influential anthropologists, such as Margaret Murray and Sir James Fraser. ${ }^{26}$ The latter was convinced that he had found a common myth, 
that of a king volunteering to sacrifice himself for his people, throughout Europe. Given the First World War saw devastating carnage, explicitly concerning national and ethnic conflict, there was politically a strong global call to find a common link that would tie all nations together and prevent future carnage. Murray believed that witches in the sixteenth century had not been involved in activities the authorities accused them of, but were part of a pre-Christian fertility cult. ${ }^{27}$ Popular writers, such as poet laureate Ted Hughes, were also convinced of this. The Nazis then searched extensively in archives related to the period, in an attempt to find evidence to support the theory that Christianity had persecuted German Aryan women. ${ }^{28}$

This reveals a strand in Nazi and neo-Nazi ideology concerned with a call for a post-Christian belief system, turning accusations of violence back on Christianity. Just because purity is a myth, it does not mean a desire for purity should be ignored. Conversely, it is often at the heart of damaging forms of all ideologies and religions. Of course, neo-Nazi gangs feed into and off youth culture. Childhood is frequently understood as what is natural, inner and positive, contrasted with the artificial world of the grown up. Rousseau posited the child as being at one with nature, but also the notion that the past is always tainted in the present. ${ }^{29}$ Despite the mystique of this context, none of the interest in the occult was especially underground, or purely part of Nazi ideology. The occult is often portrayed as part of esoteric knowledge on the fringes of the society, but it has been frequently part of the mainstream. For example, British Prime Ministers Arthur Balfour and William Gladstone were interested in psychical research, and both of the established writers Sir Arthur Conan Doyle and Ted Hughes were deeply influenced by spiritualism..$^{30}$ Elements of Nazi occult belief, such as channelling a pure native self, were part of the wider, mainstream, non-German culture, which fed into a literary tradition tied to mystical Celtic belief systems and romanticism.

Historically this strong interest in the occult occurred during a time of huge upheaval following the impact of unprecedented carnage and world war. A fragmented self, as epitomized by the 'hollow man', to use T.S. Eliot's term, was dominating the collective psyche and the rational man was felt to have failed. For Hughes, the importance of the primitive native animal self was now stressed, as it was for D.H. Lawrence. These two figures are now central to not just English culture, but global culture, epitomizing a way of thinking that has become mainstream. Donald Trump in his presidential campaign appealed to this non-rational part of the self, through rational rhetoric, although this manifested itself in numerous contradictory ways. People believed it was insanity that he 
was nominated, dismissing him as a joke, and then found it complete insanity that he won. But, rationally speaking, playing into people's basest instincts generates deep interest. Debord revealed the media instigates this irrationality with lies swamping the society of the spectacle..$^{11}$ The mainstream press galvanized this interest, with anything Trump did, such as a tweet, making headline news.

\section{Until the Next Event}

Neo-Nazi violence and its mediation through media platforms is central to the theatre of distraction. 'Until the next event' could be the mantra of our times. While the media has one eye on the current atrocity, such as a racially motivated mass killing in America, or a series of violent anti-Semitic crimes in Russia, once reported these are no longer news items, and are stored in a virtual archive. The reporting takes precedence over their reality and content. Indeed, the reporting causes the invisibility. Rather than the future distorting the past, through rewriting history selectively, the future frames the present, voiding it even of the status of an event. The form dictates the content, and Marshal McLuhan's well-known aphorism becomes fact. Indubitably, the medium is the message. There is a constant need to feed the machinery of news media, the audience given the semblance of taking part, through various feeds, adding to an appearance of excitement. To retweet, doing the job of the media, is felt to be an action, giving the veneer of interaction and control. Clicking on a link, an app, or anything similar, offers a simulation of control, stimulating an unconscious spurious belief that a level of influence is occurring.

This simulation, offering the belief in self-agency, is in practice the reverse of power. People follow the live updates on Twitter and Periscope and other platforms, as swathes of innocents are murdered and maimed, giving the followers a fake sense of intervention. Because they in some way 'witness' the events, the image or message is manipulated, and they are part of it. In the realm of simulation, it does not exist without them. A violent ubiquitous loss of signification leads to an implosion of meaning. ${ }^{32}$ If every where socialization is measured by an exposure to media messages, those under exposed are desocialized or asocial..$^{33}$ While we think information produces meaning the opposite is occurring which can be termed the 'phantom content' ${ }^{4}$ Wisdom was replaced by knowledge, then information replaced knowledge. Data, big or small, has now replaced knowledge; who has access to and owns this data is a serious question. 
Debord formulated how disinformation was attractive to the dominant society as it contained truths within lies..$^{35}$ Remarkably, it took until 2016 before an awareness of fake news became ubiquitous. By then people were not overly concerned because news was not about facts but entertainment. Hoaxes and fakery at the centre of the debate over authenticity are at the heart of discourse over the Holocaust, with neo-Nazi Holocaust deniers being so prolific on the Internet that a search for the Holocaust on the Internet comes up first with the debate over its authenticity. When it comes to fake news there is in reality nothing more occurring in this instance than total manipulation. This is more so than previously in history, which had limited forms of communication. People now believe they are actively taking part in and are choosing how they interact with media. This is the participation myth that those connected to media forms, such as Twitter, promote, boosting revenue from advertisers. Sadly, people become excited when they are following an event live on Twitter, because they are feeling part of the action, from a war, a revolution, to a sporting event. This feeling of involvement offers a spurious feeling of power, plus any information or knowledge about a system and event, 'is already a form of the neutralization and entropy of this system' ${ }^{36}$

Furthermore, if this information is broadcast it is degraded. The fusion of reality with the image negates reality. The proliferation of the face, via the selfie, or any other overdeployment of the image, destroys the human, given the real face is removed. This has dramatic consequences, if by face we take a broader meaning outside and beyond the mere biological. The Jewish philosopher Levinas is associated with the concept of the Other. This is a presence within which God exists, along with our true identity, and is a conduit to our true identity. For Levinas we can only understand ourselves through this Other. This face is not biological, ethnic, or even social. The face evoked is the concrete appearance of the idea of infinity that exists within me. ${ }^{37}$ The face then, in this context, ethically fulfils the whole purpose of Levinas' philosophy. The importance of the face is that it is perceived to resist possession or utilization.

This philosophy is beyond knowledge. Levinas invites and obliges me to take on a responsibility that transcends knowledge. The face signifies ethical knowledge, which is there from the beginning: thou shalt not kill. There is then in the face what seems like the impossible: it forces us to receive the idea of infinity, prior to engaging the operations of cognition. ${ }^{8}$ But an important question is: How can we receive an idea prior to entering ideas? Theodor Adorno claimed the Hegelian system objectifies the subject, raising it in the process to a transcendental status. But for Adorno the separation 
in philosophy between object and subject since Descartes is wrong, as they are mutually mediated by each other ${ }^{39}$ Created being (totality) is but the trace of the passing of the 'infinitely other'. ${ }^{40}$

The reversal that Levinas refers to is also familiar to those aware of Jungian psychology. 'It is not the self that constitutes the meaning of the Other's existence; rather, it is precisely the opposite: subjectivity is constituted in and through its relation with alterity.41 In this sense, one is not aware of his or her individuality until one enters into a relationship with another. This relationship calls the subjectivity of freedom itself into question..$^{42}$ 'Ethics, the welcoming of the Other by the self, is only accomplished through the recognition and maintenance of the radical disjunction of same and other, of subject and object. ${ }^{43}$ For Levinas, who was saved the fate of his fellow Jews as he was captured in Rennes in 1941 and treated as French prisoner of war, the violence endemic to sexism, racism, classism, nationalism, and so on, is the denial of the totality of being as the trace of the infinitely other. ${ }^{44}$ Levinas places an ontological awareness in otherness, and this has the possibility of the infinite. Sameness obviously is finite. Neo-Nazism would find such philosophy not just difficult to understand, but anathema to its essential ideology.

From this shift into philosophy we can enter into a more nuanced view concerning an understanding of not just what neo-Nazism is or might be, but what it does. Neo-Nazism negates the infinitely other as present in being, that is, our being and that of another. By demonizing the other, as the extreme difference beyond the same, it removes all traces of the infinitely other within the same. In the totalitarianism that dominates the majority of corporations and industries an element of this neo-Nazism has taken hold. This is not hyperbolic, or merely metaphoric. Only through such mechanisms is difference denied and homogeneity in all its form rules. This is much subtler than any overt practice of obvious discrimination, but quite the reverse. Normally this sits within a framework where equal opportunities are promoted in organizations.

For Levinas it is only through the other that there is any real truth, identity, ontological essence, being, and infinity. Despite the variety and fragmentation of groups, and within groups, neo-Nazis appear united in their hatred of 'the other', broadly defined. This unification, often electronically through the Internet, has numerous levels of paradox. We should be wary of the solidarity formed electronically for unification across the globe, given every 'strategy of the universalization of differences is an entropic strategy of the system'. ${ }^{45}$ Those caught up in the frenzy of the media, and its theatre, are tragically blinkered to this blindingly obvious 
point. Paradoxically, chasing the event on Twitter, or any other platform, is no more or less than a remote form of watching a game, in any era, with the bombing of Syria and the Arab Spring fusing via observation with viewing Roman gladiators. Indeed, the framing of these events then nullifies them of their human significance.

The semblance of participation generated by such forms allows for sharers of information to pretend to be journalists, and anyone to feel they are taking part. Depth of analysis and criticism is avoided, and is exchanged for a thrill from a press of a button that might lead to a like'. The narcissism and self-referencing of this should never be overlooked. More dangerous is the veneer it gives to the belief in personal people power, as if the public are more engaged when the antitheses is the truth. There is a constant thread concerning audience participation, which is entirely simulated. Only the latter is physically conducted, with the audience present, not hiding behind a device. Through this mechanism of the simulation of participation identity formation takes place, eliminating any dream of authentic identity, allowing for further acts of violence and the removal of freedoms.

Whether the possibility of an authentic identity is a myth is immaterial in this context. Concurrently, figures concerning the use of social media need to be questioned. The racist right-wing organization Britain First is a group that has made broad use of social media, but claiming the number of 'likes' or the number of followers on any social media platform indicates correctly the extent of real support needs questioning. For example, Britain First polled only 1 per cent of the vote in the London mayoral elections in 2016. In December 2016, the former leader of Britain First, Paul Golding, was jailed for two months. Their Facebook page read: 'The High Court has sent Paul to prison for confronting a hate preacher in Cardiff who said it's okay for Muslims to keep sex slaves!' In November Jayda Fransen, leader of the party, was found guilty of religiously aggravated harassment, after hurling abuse at a Muslim woman wearing a hijab. Labour MP Louise Haigh called for Britain First to be listed as a terrorist organization. Terrorists, activists and journalists fuse in this zone.

When a newsreel is played in the Amazon Prime television series (2015 to present) adaptation of Philip K. Dick's 1962 novel The Man in the High Castle showing the allies winning World War II and Winston Churchill in a victory parade, the paradox is within this text the Nazis have won the war. But, it should be clear by now that in many ways they have. It Happened Here (Kevin Brownlow and Andrew Mollo, 1964), is a similar example, where there is a world where Germany has won the war, and the slogan is, 'Germany and England - a community of race'. The media is an integral 
part of this victory, driven by a need to generate fear, creating division and hate. This is not a victory for random splinter neo-Nazi sects that exist in a variety of forms across the globe. That would not be a victory, despite a certain rhizomatic element making it akin to ISIS in its potentiality. Why this current engaged media is far more insidious is that it is a victory within the mainstream, not merely in media discourse, but in ontology. It goes to the heart of being. As Charlie Brooker has made clear throughout most of his Netflix Black Mirror television series, there is an appalling loss of identity through attempting to seek approval via social media. Again, using Buddhist terminology, it is not just sangha (community) that is lost, but also Buddha (truth), and dukha (awareness).

In 2016, with a rise in racist discourse and neo-Nazi activity globally, it was easy to forget that previously battles had been fought between and against the far right and the left, leading to deaths on the streets of Britain. People were once unable to hide behind social media, and so allegiances were more publicly expressed. Margaret Thatcher stood for election in 1979, a year when social unrest was becoming the norm in the UK. For example, in April 1979 Blair Peach died after taking part in an Anti-Nazi League demonstration in Southall on 23 April 1979, St George's Day. Three decades later, information was finally released that placed the blame with the police. Reports into his death were only made public in April 2010, when it was identified that the police were probably responsible for the sustained head injuries that killed him. Even three decades later, no one was willing to take responsibility. On the day of the attack against Peach, 3,00o protestors had been protesting against the National Front, with 2,500 police involved. Two years later, London witnessed the Brixton riots, and the public inquiry led by Lord Scarman, indicating Britain was involved in a race war. In the Peach case, evidence was tampered with, eleven witnesses saying they saw Peach being hit by the police, and the police at the event were found to be Nazi supporters. ${ }^{46}$

Regardless of the evidence that surfaced, despite the attention this case received no one was brought to justice. The prime suspect, Alan Murray, went on to work as a university lecturer. This confirms neo-Nazism is not on the fringes of society but at its heart. The media often dramatizes events connected to neo-Nazism to create a theatre of extremism, which is misreporting. With neo-Nazism at the heart of culture, it becomes difficult to differentiate its traits. The Metropolitan Police accepted the accusation of institutional racism in 2015, but only in terms of the police being just a reflection of society, where it was stated this was bound to happen. Following the points previously raised in relation to Baudrillard, there is the 
suggestion here that this is inevitable and unpreventable. This followed on from the MacPhearson report, published in 1999, which showed black people were six times more likely to be stopped and searched than white people. Reports do not change cultures, but often function as an excuse for justice. By 2007 this figure had gone up to seven times more likely, and in the following three years the number went up for all ethnicities. By 2012, the LSE reported that a black person was 29.7 per cent more likely to be stopped and searched than a white person. ${ }^{47}$

In a wider context, in 2016 the BBC reported that the figures for 2015 showed that 5.5 per cent of UK police officers were from a black or ethnic minority background, while these groups made up 14 per cent of the population. It is disingenuous to claim that the police just reflect society, as did Sir Bernard Hogan-Howe, Commissioner of the Metropolitan Police, in 2015. Despite claims to the opposite, the police were not a reflection of the societies they were policing, and their continuing behaviour suggested they were made up of racists, given the level of searches carried out on those from ethnic backgrounds. Outside the police, the number of attacks on foreigners following Brexit went up. The excuse given in America concerning the support for Trump was that the politicians had ignored the white working classes. In any case, there was a celebration of a certain form of animal savagery, which went against humane behaviour. The un-evolved began to triumph and Trump was shown to be channelling the group id of the American people.

The call to return America to the whites was a slogan that fuelled Trump's victory, and he had the whole-hearted support of the neo-Nazis. After his victory, he attempted to distance himself from certain right-wing groups, but the appointments he made to the White House indicated he was allying himself with the far right. There were further suggestions that key controllers of online media channels close to Trump were attempting to influence European elections, such as those in France. Angela Merkel was in a difficult position, given Germany had spent almost 70 years attempting to atone for the Nazis, with Hitler salutes and Nazi material illegal. She condemned the neo-Nazis in America that supported Trump, but also claimed she did not believe Trump was sympathetic to their cause because he had no ideology. Tangentially, it is worth noting that this may have been part of his success.

During his campaign rallies some black protestors were attacked, and Trump harkened back to the early 1960 s and 1950s in his rhetoric and media campaign. His argument was that it was right to use violence against black people, letting hatred rule victorious. Elsewhere, his views on Jews are more ambiguous. He had tweeted it was important for him to have Jews 
taking care of his money. As soon as his victory was announced, many in Israel called for the dismantling of the Palestinian state. The left-wing press had compared Trump's discourse with Hitler's. Both UKIP and the Trump campaign had almost declared defeat in advance, to make their victories seem even more impressive. The shock Brexit result was an inspiration for Trump. The churning of rumours on the Internet, primarily Facebook, was a factor in this result, but an outright condemnation of Facebook seems naïve. Denouncers of social media forget that the use of social media is voluntary. While overuse of anything may lead to health problems, should we blame the user or the tool? Trump's victory does not negate the growth of the left elsewhere, with Momentum in the UK maximizing the impact of social media. In desperate times of austerity, the majority had chosen to blame the minority, just as in Nazi Germany. Neo-Nazism is formed out of a feeling of being persecuted and then persecuting the other, which can often be led by the media.

For Baudrillard everything is the look, everyone desiring that which is more real than real. All is multiplying and with a 'mad' overdetermination. The present world is that of 'madness'. What is real does not ever occur because things are always in advance of their unfolding causes. This correlates with the previous point made on the manner in which the media moves on from events. Reality has stopped; history has ended. Concurrently, the world is saved by the spectacle, by evil itself, the only liberation being in the 'deepening of negative conditions'. The victory of Donald Trump in 2016 was interpreted in the left-wing press as the return of the revengeful white man, Trump having the support of the Klu Klux Klan, which is older than Nazism and neo-Nazism. Foucault saw a triumph of madness and for Baudrillard there is a triumph by appearance, no one ever being able to enter 'the blind spot around which the battle is arrayed'. A desire to find meaning is madness, and an absolute misunderstanding of the world as play and ceremony. In terms of social media activity, this argument is pertinent, because an involvement in this realm does involve play and ceremony, rather than meaning.

With a denigration of activity, this theorizing can be viewed as a form of madness in itself. After all, what is madness other than the 'absence of the work' (to quote Derrida)? There is a disturbing element to this line of thought that needs exploring further, because actually through his discourse Baudrillard is of course playing with the reader. One minute he states that priding oneself on difference is pointless, because indifference will prevail. The next he states that only the other knows. Unfortunately, despite this insight Baudrillard's mission to turn people to the desire of 
the world through the theory of seduction is not particularly innovative. Freud had turned people away from the desire of the mother to the desire of the self. Reason, for Baudrillard, destroys destiny because connections exist already, so all consideration of anything is madness in itself. We can envisage neo-Nazis leaping on this, seeing how destiny is central to their belief system.

\section{Trump and the Rise of the Right}

If the rise of neo-Nazi discourse following Trump's victory in November 2016 was inevitable it was nothing new; this discourse was never at the fringes of society. Le Pen in France had been flirting with this rhetoric for over a decade. But what was new was that this type of rhetoric was now not overtly condemned in the mainstream and tabloid media, and it was often seen as a joke to be dismissed as not a real threat. The media in general appeared to be behind the political momentum, unable to catch up with the new dawn of Trump. A victory for Trump was viewed as a joke; until he won. Instead of getting on with the transition and with the job, Trump just continued having social media spats with celebrities, like Alec Baldwin. The television sketches where Baldwin played Trump were not particularly funny, showing him as invariably done through skits, such as looking up ISIS on Google. In this instance Trump had a point, because the humour was not strong, but Baldwin declared he would only stop if Trump published his tax returns. Trump was fighting a war of words, rather than dealing with the real business, but Trump had fully realized that this war of words was where it counted.

The Daily Beast reported on 19 November 2016 that white nationalists and Nazi-saluting Tila Tequila were toasting 'Emperor Trump' in Washington. Again, the comedic angle was emphasized. A strange version of The Apprentice mixed with a Philip K. Dick story about the Nazis winning the war and The Hunger Games had materialized. A white-supremacist think tank led by Richard Spencer, the National Policy Institute, ran a conference near the White House in the Ronald Reagan Building after Trump's victory. Spencer, it was reported, works to make extreme policies, like 'peaceful ethnic cleansing' and a 'white homeland' mainstream. Tila Tequila, who is a Singaporean Trump-loving ex-MTV personality, with an adoration of Hitler had been condemned by the Anti-Defamation League as a person who will do anything for publicity. Tequila Tila dresses in sexy-Nazi outfits, identifying with the alt-right. Her argument is their ability to attack 
via meme wars is good for children, as it is funny, creative, artistic and magic. Certainly, by the end of 2016 the alt-right in America appeared to be winning the arguments within the media meme wars, and this was not limited to America. Trump, after some delays, denied any sympathy with the organization. Spencer then claimed everything overtly neo-Nazi, like the salute they were using, was ironic.

Spencer supposedly invented the term 'alt-right', and promotes the belief if you are not white American you should leave America. Josh Harkinson, reporting on Spencer for Mother Jones in October 2016, indicated that Spencer gives fascism a radical chic, which seems like a compliment for just getting a haircut. ${ }^{48}$ Others have played with this for decades, such as David Bowie and Brian Ferry. The level of Spencer's racism is deep and broad: blacks, Asians, Muslims, Jews, and most Hispanics, are not part of his view of the future of America. Can this rise of the right then be put down to the last shudders of the American empire, given Spencer's overt association with the Roman Empire? Empire's do come and go, and ever since the OPEC oil crisis in 1973 where the real global power was based has been questioned. America's role as the global policeman always had opponents at home, isolationism going back to founding of the America, and lasting until 1941. Trump was vociferous in his condemnation of Hillary Clinton's approach to American foreign policy, which had dragged them into two drawn-out wars. Within ten months of his victory Trump threatened all out war with North Korea.

After Trump's victory in the presidential race in November 2016, the actor Tom Hanks made a speech stating this was not the end of the world. Apparently, America would triumph, given it is the greatest country on the planet. At an unusual time in its history, we could question why this one country once again needed to state it was the greatest country in the world. Was this a statement to counteract global threats, such as Russia or China? This rhetoric, trying to inspire optimism, was outmoded, stemming from certain 1950s idealism, and was likely to add fuel to the fire of those that despise America, such as ISIS. Other white separatist right-wing media leaders included Jared Taylor, founder and editor of the white nationalist publication American Renaissance, and Peter Brimelow, founder of the website VDare. Combined with this was the CEO of Trump's campaign, Steve Bannon, ex-chairman of Breitbart News, which was popular as the New York Post, but for Spencer these are 'alt-light'. Bannon in November 2016 became the president elect's Chief Strategist and Advisor. Spencer's influences included Taylor, and Leo Strauss, a Jewish German-born professor influenced by Heidegger and Hegel. Spencer's wife Nina, who has been accused of being non-white, a dark-haired Russian, translated the writings 
of Alexander Dugin, a Russian far-right nationalist, and they both have appeared on programmes broadcast on the Russia Today television network.

The nationalistic discourse that was always present in America was given greater power by Trump's victory with people moronically chanting 'U-S-A!' as the norm, but again this can be interpreted as a death shudder. Economically hard-hit communities believed that free trade was a curse and the cause of their woes; they were unable to fathom that the world had moved on. Trump immediately set about dismantling trade agreements, in an attempt to boost American industry. This isolationist position on the surface appeared anti-free trade and in this sense anti-capitalist, but it correlated with the neo-Nazi position on creating borders and boundaries. The concept of building a wall on the southern border was a master stroke with one Mexican company even offering to supply the cement. 'Master stroke' is an apt way of describing this, as it functioned as a metaphor and symbol for everything Trump stood for, and fed into neo-Nazi prejudices against the 'other'. The wall was similar to a dam, functioning to keep the floods of immigrants out, a phrase often used in European media.

In Steve Bannon's 2011 film Generation Zero, big government and Wall Street are condemned as the two structural central evils, but the director of the film is a former banker, trained at Harvard. Simplistically, the ideas of the 1960 os get blamed for America's ills, with these ideas infiltrating every layer of society, such as communism. Newt Gingrich, former Speaker of the House of Representatives, a talking head in the film, discusses the lunar landing, in comparison to Woodstock, which is condemned as hedonistic. There is a declared split in American society between those who apparently work hard and deserve the rewards, and those who are reprobates. The latter are linked to those desiring progress, in terms of gender and race. In this film, the American Enterprise Institute talking heads condemn the rise of youth culture, claiming there is a moral decay. What the film indicates is a desire to return to the mythologized normality of the 1950 s, this despite the maker of the film personally going through numerous divorces, and being accused of domestic violence. The film is an attempt to scoop up a broad audience of disillusioned voters, from alienated old people, to neo-Nazis, and to those who hate the elite and the 'system'. This film is for the so-called 'lost tribe', akin to the group of mentioned on the back-cover blurb of the novel The Football Factory.

The 1960 are condemned as an era of moral self-righteousness and narcissism. This is termed a betrayal of the past by the elites. One of the talking heads, Shelby Steele, Senior Fellow of the Hoover Institute, condemns the 1960 activists outright, and then the film's narrative leaps to the $1990 \mathrm{~s}$ 
claiming it is the left that is in power, undermining the capitalist system. Free market capitalism is the god here, and anything that may have gone wrong with the system, such as the crash of 2008, is blamed on big government interference. Strangely, the film also appears as a condemnation of extreme greed, as epitomized by Donald Trump. While greed is promoted as being essential to human nature, extreme greed is attacked, to appeal to a wider audience disillusioned with the left. Bannon in this sense could have been Trump's worst enemy, but is here rounding up all those who are lost, or who have seen no benefit from either a Republican or Democratic government. Social engineering is blamed, as are the political elites. Five years before Trump came to power, Bannon made this overt propaganda film, calling for an overthrow of power. Nazi propaganda had condemned the elite as the cause of all ills, calling for a complete overturn of power.

Bizarrely, the film ends as a condemnation of tyranny, with a reference to Hitler and Mussolini, referring to inflation in Germany, and comparing this to the current quantitative easing, with the printing of money as the future of America. Another talking head, John Bolton (former US Ambassador to the United Nations from 2005 to 2006), attacked the decline in American military influence. The message of the documentary: Stop. Obama is condemned for being European, in regards to his approach to health care, education, and the energy system. No details are given. Paradoxically, the wealthy and the elite who made this film are using it to condemn the elites, and even the concept of social justice is attacked.

Similarly, in Bannon's 2011 film about Sarah Palin, The Undefeated, it is the elites that are blamed. As Ian Kershaw put it, Hitler's ideology was based on the belief that specific values determined a people's fate: 'blood', or 'race-values'; the 'value of personality'; and 'sense of struggle', the 'selfpreservation drive'. These were within the Aryan race, but the Jewish vices were democracy, pacifism and internationalism. ${ }^{49}$ The latter, internationalism, is condemned vociferously by Bannon in his films, and forms part of the main thrust of the attack on Obama. To claim there is no ideology here in any of these Bannon films would be to ignore the obvious points. Putting up barriers, even to the extent of building a wall, is one element of this. Blaming everyone or everything foreign is another aspect. And then inventing an apparent elite linked to social justice, which is vehemently attacked, is another part of this ideology.

Speaking as an ex-employee of Goldman Sachs, Bannon's 2011 lecture at the Liberty Restoration Foundation refers to the 15 September 2008 financial collapse, emphasizing Armageddon. He states there was a need for a trillion dollars to fix the system, and to prevent social chaos, and Bloomberg 
calculated this as $\$ 5$ trillion. Bannon blames this on Medicare, pension funds, and the trade deficit, caused by buying foreign goods from China and foreign oil. Relying on the rest of the world is the problem because anything foreign is the problem. For Bannon, the total assets of America, including all stocks and companies and cash, adds up to $\$ 50$ to 6 o trillion, with the national debt at over $\$ 200$ trillion. The welfare state is to blame. Speaking of his film Generation Zero, he claims this title reflects the current new generation, which has zero prospects. For Bannon, they know zero about history. This is part of the Tea Party, a grassroots organization that was not supported by the Republican Party. This for Bannon is the fourth turning in American history and retrospectively appears as the start of the Trump campaign.

What Richard Spencer, Steve Bannon, Donald Trump, and Adolf Hitler all have in common is their absolute condemnation of the media. This goes beyond a normal scepticism. Spencer has used the German term Lügenpress (lying press), which is how the Nazis described the media, condemning the press for being run by Jews. In response, in November 2016 Twitter suspended his account and that of other white supremacists. Other alt-right supporters, such as Milo Yiannopoulos, an associate editor at Breitbart News, were also criticized. Yiannopoulos was due to return to his old school, the Simon Langton Grammar School in Kent, but the visit was cancelled after officials at the UK Department for Education expressed concerns over safety. This had nothing to do with the planned content of his speech, but concerns that counter-extremists would protest. Langton sixth formers had signed up to the event with parental consent. The school's head of politics, James Soderholm, had invited Yiannopoulos, who had been banned from Twitter for life in the summer of 2016 for making racist comments. Appearing on the Channel 4 News, Yiannopoulos in his defence sold himself as a maverick outsider, a gay Jew, claiming his journalism is just mischievous. 'Am I supposed to take this as a joke?', asks presenter Cathy Newman, of statements such as, 'If we allow mass immigration, get ready for mass rape.' He then launched into an attack on 'victim culture', which apparently must come to end, and claimed the wage gap is a total conspiracy theory. However much these people dress themselves up as outsiders, they are straight from the elite themselves, having gone to private schools and colleges. His moment of fame was short lived. After proclaiming the benefits of boys having sexual relationships with men, he quickly resigned from Breitbart News and lost a book contract deal.

Within this discourse, political correctness is a 'cancer'. Between the late 1960 s and the 1990s there was a movement towards social justice, but 
this was not linear. Logically, one would expect a backlash. Yiannopoulos claimed to know what American's were thinking, given lots of people followed him, especially the gay community, despite him now being banned from Twitter. Trump and his allies were apparently functioning as radar for the American repressed id. Yiannopoulos had an exaggerated narcissistic self-importance that was believed by the global. Yiannopoulos gave interviews all over the world, during a period of great uncertainty following Trump's election. Unlike Cathy Newman on Channel 4, most journalists saw him as the refreshing face of modern journalism. Multiculturalism and globalization are the enemy here, for Yiannopoulos, with Islam being anti-gay, anti-women and pro-terrorism. Feminism is anathema. Israel becomes a model for nationalism, globally. Those who found his beliefs outrageous should be condemned as the extremists, for not allowing him to have or express these beliefs. This twisted logic continued after Trump's election. The narrative was they had been silenced for too long and this was their time. Those that demanded equality for all were 'pussies' and they constantly repeated their right to proclaim uncensored discourse, including hate speech and racism.

The fact that Donald Trump retweeted a neo-Nazi's tweet in January 2016 created a mild protest, but this only added to his profile in the run-up to the election. Trump appeared to be able to get away with anything. In a world that had evolved into a system where having respect for others was not abnormal, Trump's abnormal disrespect was admired as refreshing. In this regard, those critics of political correctness were correct. The public appeared to have had enough of being told what was appropriate, a very vague term anyway, and Trump and his associates capitalized on this. The media appeared to keep venerating and courting Trump, because of the need for profiteering from advertising, so no one properly challenged his racism or other outrageous opinions. Trump continually played the game of attacking the 'evil' media, and attacking the election process, just in case people might not vote. Even after they voted for him he claimed the voting system was rigged. Building on a culture of mistrust and conspiracy theories, Trump fuelled the fire, turning people away from some simple facts. Indeed, he even appointed neo-Nazi sympathizers who had no political experience to important positions.

Berating the media for being biased, his war with the press presents an image of someone who will not be pushed around, which again changes the political norm. Trump excluded the press from presidential events, where previously the press had been allowed, such as foreign visits. This lack of transparency and avoidance of questions from the press meant allegations 
of incompetency, fear and corruption could be made. Any association between his key advisers and the far-right groups and neo-Nazis was dealt with by a condemnation of these groups. Rather than a two-way process, statements were made, plus tweets written. In the build up to the election before November 2016 social media was crowded with allegations Trump was a fascist. Following his victory, the mainstream press just vaguely asked: Is America drifting towards becoming a banana republic?

Bannon was considered by numerous commentators to be a neo-Nazi, so the closest adviser to the president was now feeding him these extreme beliefs. Early on Trump had tried to distance himself from the Klu Klux Klan. When asked on 26 August 2016 on Bloomberg Television about the support of David Duke, former Klan Grand Wizard, Trump said he had never heard of him. But Trump had mentioned Duke as his reason for a previous failed attempt at running for the presidency. In 2000 Trump issued a statement saying he was not running for president with the backing of the Reform Party because Duke was a member. Despite vague attempts at distancing, Trump's rallies still became zones of violence against non-whites. In November 2015 he stated in Alabama that blacks needed to be 'roughed up'. This volatile rhetoric fed an appetite for racial violence that ran deep in the region. When he was less popular he had to tone down his rhetoric, but as his support grew Trump's overt racism was constantly commented on by the media. The first sitting senator to endorse Trump was Jeff Sessions of Alabama, who had been rejected in his application for a federal judgeship in 1986 for apparently saying he had thought the KKK were 'OK'.

Dressing casually, verging on the scruffy with his unshaven face masking his establishment education, navy training, and finance career, no one can consider Bannon, the primary influencer on Trump and the American media, as not from the establishment. And yet his media outlets did a remarkable job in claiming they represented the non-establishment, the voiceless, the powerless and the dispossessed. The possessing class running the state is overt, with people like George W. Bush and Donald Trump in power, although the latter claimed a new dawn of anti-establishment politics. The neo-Nazis were cohering with the interests of high capitalism. As with Trump, they did this via an ideology which was lower middle class..$^{50}$ Both the neo-Nazis and the Bannon propaganda machine castigated the upper-class 'parasites', including bankers, despite Bannon having a career as a banker. This was a form of radicalism of the right, which denies civilization, appealing to the radical in those who, the system has not benefited.

The end-of-time rhetoric pumped out by the Clinton and Trump team prior to the November 2016 presidential election was black and white: 
there was a choice between God and the Devil. Hillary was the witch, but anti-Semitism on the right was hard to pinpoint, given Trump had immense support from the Jewish community. Both the left and the right had attacked the technocratic society, ever since it existed. The rhetoric was framed to enable Trump to dismantle the state, reducing the need for any protection of the poor, dropping taxes and changing inheritance tax laws. Comparisons between Trump and Hitler had been misplaced. Initially, he did not have an expansionist agenda. What appears as a selfdeclared white power movement from the inside, from the outside looks like a white inferiority complex. Right-wing commentators in America saw Israel as a correct model for America to follow, given its aim of an ethnostate.

As the world approached the 2020s, the core conspiracy theory was just a repetition of the 1920s. During this period, the National Socialists claimed the Germans had actually won on the World War I battlefields, and they spread the belief that it was the Jews in government that had betrayed the nation. There was then the conspiracy theory that the Jewish financiers were raiding the economy. This is the perpetual myth repeated again throughout the last hundred years. Richard Spencer's neo-Nazism has total synergy with the views that there are actually two enemies, which is part of the metaphysical struggle. These enemies are: the Jew-Capitalists and the Jew-Bolshevists. The solution in Germany was for the Nazis to establish a community under a supposedly divine leader, but in America in the 1920 s unification of white supremacist and anti-Semitic organizations did not materialize. In 2016, this unification occurred to a degree, uniting behind Trump, despite him distancing himself publicly from support from organizations like the alt-right.

As fringe groups with undeclared support at the heart of culture in the 1980 s and 1990s became mainstream, Trump was guided by Bannon on how to win this vote. A 2016 book on Trump's rise to prominence and his presidential campaign used the word 'Nazi' six times in the context of his presidential campaign, including elements of the iconography of rallies and salutes. Neo-Nazism had filtered into the Trump campaign, and was nothing overtly to do with Richard Spencer's movement..$^{1}$ The latent and blatant neo-Nazism that was evidenced at this time to the build up to the November 2016 presidential election reveals the manner in which neo-Nazism can be incorporated into mainstream politics. The period 2015 to 2016 witnessed a global shift. Citizens often cast aside traditional parties, or traditional leaders, opting for the anti-establishment figure, however much in practice this description was inaccurate. 
Trump did not materialize from nowhere. His use of Twitter is just one part of his media influence. For four years prior to his presidential campaign, Trump appeared normally by phone on Fox \& Friends, billed as 'Mondays with Trump'. There was a symbiotic surge in support for Trump and a rise in ratings. According to Nielsen Media Research, between February 2016 and February 2017, ratings increased by 46 per cent. The show had allowed Trump to dominate as a platform for his strange musings, especially on Barack Obama's birth certificate, with citizenship, identity, nationhood, and religion all involved in this. All of his claims were broadcast without any critical invention by the show's hosts, Steve Doocy, Ainsley Earhardt, and Brian Kilmeade. This slot can be interpreted as a free one-man party political broadcast, on the most popular morning show on cable television. The Fox News Channel was formed in 1996, after Australian-American Rupert Murdoch employed Republican Party media consultant and CNBC executive Roger Ailes to be its CEO. Murdoch is still its chairman and acting CEO. The channel is continually criticized for being biased. Headlines on networks such as CNN declared Trump the Fox News president. Never in history had there been such a close relationship between a president and a media outlet.

Overall, it would be wrong to view Trump's election as a new turn encapsulated as a movement towards an unprecedented post-truth era. Media and cultural theorists had been examining phenomena connected to this as far back as the 1970s. If the medium is the message, then Trump's use of Twitter is basically saying: This is the way it is; there is no room for debate. Blasting off 140 characters is a form of headline-grabbing journalism, without the delay and editing of gatekeepers. The whole approach was a rebuke to the editors who believed they had the say on what the general reading public believed to be truth. Despite this, Trump's election was a clear statement to everyone globally that truth, in terms of governance, overtly no longer mattered at all. This was then a subtler shift than has been recognized. Media theorists and philosophers such as Debord in the 1970 s and Baudrillard in the 1980 s had predicted this. Societies were being managed via media manipulation and knowledge was eroded.

In Austria, after a second election in December 2016, due to postal vote irregularities in the first one in May, some were relieved that the far-right candidate Norbert Hofer was finally defeated in the presidential election. But Hofer's nationalist Austrian Freedom Party did gain 46.7 per cent of the national vote. Anti-immigration parties were all gaining support across Europe, especially in France, the Netherlands and Germany, where elections were taking place in 2017. Supporters of the European Union viewed the 
Austrian outcome as a good sign that openness and liberal culture could prevail over the wave of right-wing populism. Trump had capitalized on this postmodern era. This involved no special skills or talent, although there is an extraordinary veneer put on this activity, mythologized as verging on paranormal power, both in its impact and significance. The media generated around these activities leads to this semblance of ability. Always outsmarting your opponent and never being predictable is part of the equation. Capital itself takes on a magical quality. The controllers of this capital, such as Trump, are the magicians. People will do anything to be close to power. Constantly calling the other 'evil' conjures up the concept that evil may exist, deflecting from any other evil perpetrated by the name caller. Unlike his initial candidates in the race for the nomination by the Republican Party, Donald Trump never had to worry about offending anyone, as he did not need any financial backers (or so he claimed). Big business was the stated overt enemy, as it had been to the Nazis. This rhetoric was aimed at appealing to the working classes who felt exploited, and small businessmen who believed they were unable to compete.

\section{Conclusions}

Despite very real fears concerning Trump's connections with the far right, any connected neo-Nazi agenda was just a cover. A veneer of neo-Nazi belief is employed to generate support, overtly borrowing from their tactics which is utilized as a tool to gain power. Once in power, various policies are introduced to benefit the actual elite voted into power, as the reward for their support, and to firm up this support, such as drastically reducing taxes, especially inheritance tax. Once defeated on ObamaCare, Trump was nonchalant, as this meant more time could be taken on cutting taxes, bringing him personal benefit. All methods of benefiting those in power are implemented, and appointments strategically made, to hold on to this power perpetually. This form of class warfare by the power elite is then an attempt at regressing society away from progress and equality, which threatens the elite power base. Equality of race, religion, class, and gender are significant. Equality is demonized as inequality, the jargon and slogans being that it is benefiting those who do not deserve it. The UK government had employed the same rhetoric when benefit cuts were announced in 2015.

This is moving towards what is otherwise known as 'crony capitalism', following Luigi Zingales. ${ }^{52}$ Other examples of overt crony capitalism include the activities of Italian politician and media mogul Silvio Berlusconi. Public 
relations firms linked to media companies were enabling political agendas satisfying vested interests and promoting certain ideologies. Nothing had changed since Mario Puzo and Francis Ford Coppola wrote the screenplay to The Godfather Part II in 1974, which reveals how an extensive power base, financially and politically, is formulated. George Lucas, Coppola's assistant, encouraged him to take the project for financial reasons, after Coppola first rejected it. This trilogy of films (1972, 1974, 1990, all directed by Coppola), based originally on Puzo's 1969 novel of the same name, while focusing on the figure of the godfather, actually unearths how political figures must be bought by underhand businessman. The films explain how institutions, from the family, to the church, to governments and courts, adapt their morals to justify themselves, and this is typically part of capitalism. In the Trump era, the relationship between business and government is no longer underground, but is raised up as quintessentially American.

Racism can be seen to be at the heart of the American dream. The complexities here stem from American racism, in this culturally specific environment, against the Italians, covered in the film. Actual war service by Michael Corleone (Al Pacino) is viewed as making him a true American, and guilt free, regardless of his illegal activities. But when he returns from the war he is alienated from his family, explaining that their methods are not his methods. Michael's patriotism is unquestionable. In a flashback sequence, Sonny Corleone (James Caan) lambasts his brother for putting his country before his family. In this sense, Michael's tribe is beyond the blood ties of the clan, which subverts a form of racism which states only that part of the family clan are pure and worthy. This, however, is still a form of nationalism that can easily slip into extremism. The moral message of The Godfather is overt: power always corrupts.

As with the Nazis, the strength of the purity of the family is emphasized. And yet Michael goes beyond blood ties, which is evocative of his strength and wider appeal. Loyalty is beyond blood. Michael's consigliere (lawyer) Tom Hagen (Robert Duvall), essentially an adopted son of the family, is asked whether he wants to fully step into Michael's world. Michael's own family betrays him, causing him to have his brother Fredo (John Cazale) killed. This is the story of America itself. Whether through a cultural product, such as a film, or a politician like Trump who became a reality TV star, there is always an attempt at claiming authenticity, suggesting antithetically a lack of authenticity. This can be interpreted as a crucial aspect of Nazi and neoNazi ideology, where authenticity is raised up as both a realistic possibility and an absolute goal. But this is obviously a fallacious quest, given there never was a pure origin, or an absolutely authentic way of being, especially 
in an American context. Even the indigenous population of America prior to the European conquest was extremely diverse.

Like others who have drawn on extreme discourse, Trump manipulates the dichotomy between the insider and outsider. The former insider status appeals to the population that feels under threat, and the latter outsider status appeals to those who believe they are now the total outsiders, also under threat. In both cases the enemy is asserted. When extrapolating analogies or parallels and patterns historically we need to be careful, but the tactics of those wishing to keep power have not changed. These were the same myths pushed by the Nazis in the 1920s and 1930s, when they claimed non-Germans had taken over the financial systems and the media. The manufacture of fear along with the message that evil is out there waiting to get you is triumphant. Trump's attack on the media is virulent and a departure. President George W. Bush took the stance of a cowboy in his rhetoric, using phrases such as, 'we're going to smoke them out', referring to how America would deal with terrorists. Bush retrospectively does not look so extreme since Trump's regime won power. Trump's main modus operandi is that he appears to not care, and this generates support and offers what could be interpreted as a nihilistic freedom.

The narrative myth propounded by the Trump camp is that the legacy generated over decades for the marginal and the oppressed are false concerns and human rights are myth. Both the Nazis and neo-Nazis thrive off hate, and are set up in opposition to what they consider to be the establishment. This same myth is propounded by Trump, overtly and full-heartedly. Why should he care if his stance towards China antagonizes the Chinese and places 40 years of delicate diplomacy under threat? This mantra of the survival of the fittest, or an 'America First'-style manifest destiny, blended with pseudo-post-Nietzsche philosophy, all might be drawn on by various white power groups. These groups or movements claim to support Trump, but he is driven by capitalism; one feeds on the other. The level of paranoia is significant. Both the left and the right are on high alert because of the enemy within. The intense attention paid to finding an enemy both within and without is fundamental to this culture of fear. 


\section{Globalization}

\section{Europe, Asia, Africa, and Latin America}

Questions over race and nationhood are more widely exemplified when globalization is explored. A good example of this is in India, where the Hindu nationalist Bharatyia Janata Party describes the race of 'Aryans' as indigenous. ${ }^{1}$ This then constructs those who are Muslims as aliens. The relationship between Nazism, neo-Nazism and globalization is multifaceted, with the original Nazis having to make a series of international treaties, but the far right in general is anti-internationalism. Those with neo-Nazi beliefs who may have been in isolation are now through new social media platforms part of a global network that transcends class and country. In Germany, there is a new generation of Nazis, known as Kravattennazis, literally translated as 'Tie Nazis'. They are well dressed and middle-class professionals, not the clichéd skinhead. Globally, neo-Nazis appear to emphasize smart clothes and education, to suggest they are part of the establishment.

Poet Michael Rosen writes in his poem 'Fascism: I Sometimes Fear ...' that fascism works by normalizing itself, by being your friend, protecting your job, your house, taking away 'anything you feel is unlike you'. What he fears is that, 'people think that fascism arrives in fancy dress/worn by grotesques and monsters/as played out in endless re-runs of the Nazis'. Sartorially astute neo-Nazis are no more international in scope, seeing globalization as destructive because it is working against national pride. The Immortals believe that Germany is for the Germans, and it is positively anti-globalization. This group attempts to recruit from the upper classes, seeing any concession to immigration as a weakness. A simple question for those seeking to have their homeland for a select group of people is: Can we go back to a pre-globalization period, or is this just fantasy? As Britain is learning with Brexit, any restriction of the movement of people into the UK may also restrict the movement out of the UK. German nationalists speak the same language as British nationalists. They believe they have become second-class citizens.

Across the world the beliefs, language and symbolism of neo-Nazism has seeped into numerous movements, including: Pegida in Germany; the Greek Golden Dawn movement, which has adopted a swastika-style logo and neo-Nazi forms of violence; in the Ukraine, the Azov Battalion has fought under a banner with a swastika-style logo; in Hungary, the Jobbik 
Party was ultra-nationalist. A range of countries in Asia, Africa, and Latin America are surveyed here, including Taiwan, Mongolia, Malaysia, Turkey, Namibia, Sweden, and Peru, indicating the scope of the global nature of neo-Nazism. We shall explore the world of the Nazi hunter which has taken people all over the globe, especially to Latin America. Some examples are more influential than others, both in their size locally, and also in their international influence.

The Grey Wolves (Ülkü Ocakları) in Turkey have had a wide impact, their breadth of support a good example of how neo-Nazi beliefs can take hold, leading to extreme violence across traditional borders. Their success illustrates how those right-wing groups calling for a curb on migration have actually been successful due to migration. This group is not the only one where there is a significant incongruity between the ideology and the reality. The transnational scope of Nazism and neo-Nazism, especially through the media, has been highlighted so this should not be surprising. The fact that Nazism has fed into a variety of forms via neo-Nazism in different cultures and times indicates that the tropes and beliefs are transferable, and go way beyond the cultural context of Germany. Even though Nazi iconography is globally recognizable given the reach of World War II with its devastation and aftermath, it is significant that there is an essence that is far more primitive than Nazism.

In terms of transnationalism, there are a number of examples. German white separatist organizations gained inspiration from American white separatist movements, which, in turn, were informed by early Nazism. Local variations on Nazism and neo-Nazism exist globally, the symbols and belief systems rebranded, often linked to national identities and a feeling of threat to local cultures, and in some countries this is linked to environmentalism. While it is still open to further analysis, Germans were indoctrinated into accepting that Jews were inferior, as were other 'others' for the Nazis. The Nazis played on economic interests, and gained support through denouncing Jews as the root cause of the problem. This emphasis exists in a variety of circumstances and has been used to denounce Muslims. Globally, it is no coincidence that an economic crisis has led to a rise in support for right-wing parties that are close to some of the Nazi beliefs, the central one concerning purity of the home population. Indigenous Latin Americans have constructed a narrative that the invasion of the Americas by the conquistadors was actually part of a Jewish plot, with a global conspiracy stemming from the fifteen and sixteenth centuries. This was the period when Jews were actually being driven out of countries in Europe, especially Spain. 
Given the global nature of the phenomenon of Nazism and neo-Nazism, with beliefs disseminated and refashioned globally by the media, global organizations such as the United Nations have attempted to confront these issues. In 2012, the United Nations General Assembly adopted Resolution 67/154 on, 'Glorification of Nazism: Inadmissibility of Certain Practices That Contribute to Fuelling Contemporary Forms of Racism, Racial Discrimination, Xenophobia and Related Intolerance'. The resolution focuses on concern about the glorification of the Nazi movement and the various members of the SS. The resolution goes on to point out the problems over erecting monuments and memorials and holding demonstrations glorifying the Nazi past, the Nazi movement and neo-Nazism. In not too condemnatory language it expresses concern at attempts to desecrate or demolish monuments erected in remembrance of those who fought against Nazism during the World War II, as unlawfully exhuming or removing the remains of such persons. It urges states to fully comply with their obligations under Article 34 of Additional Protocol 1 to the Geneva Conventions of 1949. There is also deep concern at attempts of commercial advertising aimed at exploiting the sufferings of the victims of war crimes and crimes against humanity committed during the World War II by the Nazi regime. But 22 countries of the European Union did not support the United Nations anti-Nazi resolution, and chose to abstain. Even Iran and Syria voted to support the anti-Nazi resolution, together with Israel and 120 other member states of the United Nations.

These attempts are noble, but there are obvious contradictions at the heart of racism and racialized discourse, and anti-racism discourse. With globalization and the potential to transgress traditional boundaries there is simultaneously the move to re-focus these boundaries, and narrowly define racial and national identities. Donald Trump was not the first leader to state that citizens must show an unwavering allegiance to their national home culture, and this involves relinquishing other identities. In Britain tests to prove citizenship were introduced, full of absurd questions highlighting that answering questions cannot prove anything. If we attempt to move beyond racism, then we need to recognize that there will be those clinging onto all sorts of beliefs and myths, including those such as, 'biological determinism, desire for imagined cultural and biological purity, and myths about the immutable qualities of different cultures and ethnicities'. ${ }^{3}$ None of this is black and white. Media discourse has enabled anti-racism to paradoxically assist racial classifications, counteracting attempts to de-racialize popular culture. ${ }^{4}$ Terms such as 'mixed race' automatically assume a form of singular purity, with people always being 
classified, monitored, and defined by their relationship with a 'pure' white centre.

Globalization has been perceived to not have benefited everyone, especially when right-wing movements, organizations, and parties construct globalization as a form of colonization that challenges the fundamentals of a society. This either/or position plays directly into the hands of those who wish to go back to a past that never actually existed. Being anti-international is actually a key policy of fascism, especially Nazism. Taiwan, for example, has the National Socialism Association (NSA). Trump angered China over his close relationships with Taiwan, and had to back down from overtly backing their independence, for fear of retaliation from China. This NSA in Taiwan is a neo-fascist political organization, founded in Taiwan in September 2006 by a female scientist, Hsu Na-chi, believing in the ideology of Nazism. The constant political struggle between the Kuomintang (Chinese Nationalist Party) and the Democratic Progressive Party dominated Taiwanese politics, and so the NSA wanted an intervention in the two-party state. The NSA was registered as a public organization under Taiwanese law in September 2006, and so neo-Nazism has been legitimized, although global knowledge of regions in Asia only occurs via the media once Western figures like Trump are involved. Countries then become pawns in a wider global political game, giving neo-Nazi groups leverage through asserting vehement nationalism against such perceived oppression.

In the Western world, it is often highlighted how Britain and America are different in their approaches to freedom of speech. The former has stricter laws than the latter. In Taiwan, the government indicates that the establishment and existence of the NSA are protected by the constitution, which guarantees freedom of speech and organization. They view Hitler as the leader of their group, being condemned by Jewish human rights groups, aware of their reification of Nazism. In Asia, these local groups appear to be a way of defending local interests against what is perceived to be colonial oppression, such as that from China. Even superpowers have used similar rhetoric, with Donald Trump attempting to remove free trade agreements under the rhetoric that America is being swamped with cheap foreign goods. Hitler had used such rhetoric during the build up to World War II, claiming that foreign powers had enforced too much of a draconian punishment on Germany through the Treaty of Versailles after World War I. This rhetoric appealed to the German people, fuelling a level of grievance that gave a powerful source to a sense of necessary justice, and gave him significant support. The Germans believed World War I was forced upon them, and that the five year fight had been a noble one. They concluded 
they had been cheated by the allies over the terms of the Armistice and 'stabbed in the back' by the Reichsfeinde, socialists and Jews, who had used the moment to gain power. ${ }^{5}$

Blaming foreign intervention, across time and geographies, is a popular trait of fascism, in whatever form, as is condemning internationalism. Anything that goes wrong can be blamed either on an immigrant, a foreign nation or movement. This is not a trait just of fascism, however. During the world economic crisis of 2007 to 2008, British Prime Minister Gordon Brown blamed the international system, rather than his own economic policies, such as deregulation of the City of London, which allowed banks to operate without interference. This blaming of an ethereal system was one thing, but we need to consider the impact of this recession on the wider rise of neo-Nazism. Brown admitted he did not see the scale of the crisis coming, the worst financial crisis since 1980, under Margaret Thatcher, when unemployment reached an unimaginable height. In this regard, Brown's mismanagement of the economy played a significant role in the instability to follow, making a global impact in Asia and America. Different nations and groups have learnt from each other via the globalization of the media, in terms of controlling and using the press, to support their propaganda. Given access globally to the Internet is becoming easier, ideas connected to Nazism and neo-Nazism can flow more easily in what on the surface appear divergent cultures.

It would be wrong to state that each country and time period was the same, but Hannah Arendt's views in The Origins of Totalitarianism (1951) are enlightening in a variety of contexts. Here she explains how often the supporters of these movements are non-political people, who are seeking some form of stability, when the real situation is far more nuanced. The key to understanding totalitarianism is the ability to understand the need for rootedness amongst populations. The difference between political movements and totalitarian movements is that that latter employ violence. Arendt showed how the terror of totalitarianism concerns the removal of the human to support an idea, whatever idea that might be, and however removed it might be from reality, such as racial superiority or the march of history. Psychologically, this range of racist beliefs is not something culturally specific, although America does seem to be extreme in one area. Arendt divides camps up into three: the refugee, labour, and concentration camp. Prisons are part of this system, as is Trump's idea of building a wall. America, where one in six African Americans will spend some time inside prison, has racism at its core.

Totalitarianism and fascism are not unique to German Nazism. In terms of globalization, none of this wider influence should be surprising, given 
the preference for parochial interests. Populist support for nationalism has Trump as a role model, globally. During a march against fascism in London on 18 March 2017, a group identified as the neo-Nazi English Defence League (EDL) shouted pro-Trump slogans. The importance is in the language and terminology utilized. Trump called what he was leading a movement, not a party, focusing on the apparent alienation of the people from government. His role globally has been to unite disparate local groups like the EDL under the banner of anti-immigration and anti-Islam rhetoric. Through the constant global attention to Trump, the media have in part enabled this unification of splintered groups, and strengthened their supporters' sense of purpose, mission and validity, pushing their beliefs even further to the centre of public discourse, globally.

Mongolia is interesting in terms of the utilization of neo-Nazism ideology, symbolism and rhetoric. It implies that Nazi and neo-Nazi beliefs can be taken and used to fit most cultures, even one that was actually persecuted by the original Nazis, just as we find examples of neo-Nazi Israelis. This suggests that the feelings behind these beliefs are ancient, and not necessarily Nazi and neo-Nazi, the latter existing as a framework and model within which to operate. Tsagaan Khas (White Swastikas) is a Mongolian neo-Nazi organization, founded by Ariunbold Altankhuum, known as Big Brother that claims to have 3,00o members. The groups mission is to preserve their national identity and while they claim to support Adolf Hitler in his ideology they dismiss the notion that they are extremist. They do not support violence, but they are self-proclaimed Nazis who support nationalism rather than fascism. They strive to stop interracial marriage and are especially against the Chinese. The group's members dress like Nazis, making use of the Nazi greeting, utilizing all the standard signifiers, such as Nazi colours, and the Nazi eagle, identifying the swastika as an ancient Asian symbol.

Hannah Arendt noted that those that believe in totalitarianism are not necessarily the uneducated. In Asia these groups have deliberately set out to redefine themselves as not part of an uneducated sect. The White Swastikas work closely with other ultra-nationalist groups. Despite the denial, the group has been accused of promoting violence against interracial couples. Some of their music played in clubs includes lines about shooting Chinese people. If this discourse was transferred to America this could be interpreted as resistance against oppression, just as the black community need to defend themselves against white oppression. This indicates the state has been open to the free flowing of these beliefs. Yet the group claims it welcomes law-abiding visitors of all races. There is a pattern here linking neo-Nazism globally, with a simple positioning on the other all the ills of a 
society, a tradition that goes all the way back to scapegoating, placing the 'sins' of the culture on the animal and banning it.

These groups globally relate to a threat the male population feels to their own masculinity, with sexual and gender politics at play, especially in the first example given concerning Hindus and Muslims. The group claims it is just a law enforcement body making sure Mongolian girls are not falling into prostitution and having sex with foreigners. While the use of violence cannot be condoned, there do appear to be ulterior motives for this behaviour, linked to the stated belief in local ethnic purity, but sexual tourism is a very real phenomenon. Wealthy Western tourists as well as Chinese visitors target poor Asian countries where prostitution is prolific. With regards to Mongolia, the US state department warned travellers of increased assaults on interracial couples, including violence carried out by nationalist groups.

Donald Trump's scepticism over the impact of human behaviour on climate change is well known. Neo-Nazi groups do have a correlation with some survivalist groups, especially in America, that have turned their backs on the city, and returned to the land. There a complex relationship between nationalism, fascism, and environmentalism, often in cultures where foreign nations are perceived as seeking to exploit them. Members of the White Swastikas moved their focus from attacks on foreign men who they believed were exploiting their women, to environmental issues, rebranding themselves as an environmentalist organization, fighting pollution by foreign-owned mines. There is a deliberate focus on attempting to acquire legitimacy tied into this environmentalist agenda, through sending Swastika-wearing members to check mining permits. In an era of global austerity, following the global economic crisis, agencies, including the police, claim to be underfunded, so organizations argue they must take things into their own hands.

Behind this rhetoric concerning environmentalism, the question is whether they are actually scapegoating and attacking the innocent. Some of their behaviour is certainly extreme, such as threatening to shave the heads of women who sleep with Chinese men. Much about this group is paradoxical. Even though they claim to not support the killings the Nazis carried out, they do embrace Nazi ideology. This is difficult to understand, given that during the war captured Soviet soldiers who appeared to be Mongolian were executed by the Nazis. In England, far-right groups have attacked Eastern European migrants, who paradoxically sometimes have far-right connections themselves. Contemporary far-right groups in Europe have attacked Mongolian migrants. Not all ultra-nationalists use 
this iconography. Widespread ignorance about the Holocaust and other atrocities may help to explain why some do. They have a population of under three million, and believe they need to maintain their blood purity, hence the rejection of mixing with the Chinese.

When assessing how these ideas are transferred transnationally, it is of note that nationalist groups came to the fore in Russia after the fall of the Soviet Union. With Mongolia, often perceived as a satellite state of Russia, these ideas fed into society and combined with its unique brand of neo-Nazism, which directs hatred against the Chinese. The issue concerning China is a wider one, given China is asserting influence in the region, which could be construed as imperialistic. Globalization in general is construed as a threat to local identity, and one way of combat this is to incorporate Nazi and neo-Nazi methods in defence. This includes utilizing violence against anyone constructed as other, such as those who are transgender, or any other perceived 'other' who are threatening what is traditionally perceived to be normal. A resurgence of nationalism is understandable in regions like Mongolia that feel under threat, landlocked between Russia and China. These two powers have historically competed for influence and sometimes complete control of the country. There are legitimate concerns about foreign exploitation of mineral wealth that fuel nationalistic fervour.

There is an obvious link between neo-Nazi groups globally regarding their beliefs, and often this unity occurs through cultural exchanges achieved via new media, especially through music. This is not to say that these groups are uniformly identical, with all having their local variations, depending on local political issues, such as environmental challenges. Malaysia is another Asian country that has its own brand of neo-Nazism, and this is linked at promoting what they term Malay power. Their aim is to rid their country of any non-ethnic Malays and stop immigration into the country, concerned with keeping a 'pure' Malay community. All manner of crime is blamed on immigrants, as it tends to be globally. The influence of American and British neo-Nazi culture is noteworthy, given they listen to American and British Nazi bands like Screwdriver and Angry Aryan.

Before it is implied that neo-Nazi belief and behaviour is somehow justified due to postcolonial oppression, the next group of neo-Nazis needs to be considered. Globalization has enabled the movement of people across borders. The Grey Wolves (Ülkü Ocakları) is one of the main neo-Nazi groups in Turkey, and has a broader geographical impact due to diaspora. This group, which distributes copies of Mein Kampf in Turkish, is part of the Nationalist Movement Party. Although the leader, Devlet Bahçeli, attempted to reform the party, its violence is still renowned. The Grey Wolves 
started in 1968, led by Alparslan Türkeş until 1997 when Bahçeli took over. It is active in Turkey, Northern Cyprus, and Western European countries with significant Turkish populations, such as Belgium, the Netherlands, and Germany, plus Iraq, Syria, Tatarstan, Bashkortostan, Chuvashia, and China (Xinjiang) and is banned in Azerbaijan and Kazakhstan. This is not a bunch of skinheads absorbing the sartorial signifiers of a transgressive style to assert their identity. The group's ideologies include: Turkish nationalism, pan-Turkism, anti-Kurdism, anti-Armenianism, Russo-phobia, and anti-communism. They strive for an ideal Turkish nation defined as Sunni-Islamic only inhabited by 'true' Turks and they are hostile to nonTurkish elements within Turkey.

Hannah Arendt's observations are relevant, with the view that fascism is essentially about the homeland and rootlessness. The homeless Kurds are frequently the focus of all forms of attacks by various nations. In Germany, the Grey Wolves are monitored by the authorities as an extremist organization. Many events are alleged to have been linked to the group, including: the Taksim Square massacre in 1977; the Beyazit massacre in 1978; the Bahçelievler and Maraş massacres in 1978; the Pope John Paul II assassination attempt in 1981; the Prime Minister Turgut Ozal assassination attempt in 1988; the coup d'état attempt in Azerbaijan in 1995; and the Bangkok bombing in 2015. In 2016, the Swedish Minister of Housing, Mehmet Kaplan, sparked controversy after a photograph of him emerged having dinner with members of the Grey Wolves. Kaplan, a member of the Green Party which forms part of the coalition administration with the Social Democrats, was seen with the president of the Swedish branch of the Grey Wolves. Mehmet later compared Israel's treatment of Palestine to that of the German Nazis' treatment of the Jews, and resigned. In Germany, a group known as the White Wolves Terror Crew was banned in 2016. They had formed out of the fan club of the band Weisse Wolfe (WWT), with the aim to carry out violence. In January 2016, a group known as the Oldschool Society was charged with planning to bomb refugee shelters and assassinate clerics.

While we might expect neo-Nazism in Europe, an African component is more unusual. According to NamRights, a national private human rights organization in Namibia, a number of German-Namibians glorify Hitler and Nazism. This glorification is achieved through selling Nazi-related artefacts in tourist shops in the coastal town of Swakopmund and on their tourism farms. Nazi fugitives are said to have been hiding there since 1945. Article 23 of the Namibian Constitution prohibits Nazi ideology and the spreading of its propaganda, the latter point open to interpretation. The influence of the media is important, given some media outlets such as Namib argue 
that these rumours are entirely false, and are spread from Norway-based Internet magazines, and are not in Namibia. There is an economic element to this. Owners of shops in Swakopmund would claim that the interest in the products does not stem from an interest in the ideology. The interest in Nazi globally memorabilia is remarkable, but it is arguable whether people interested in the artefacts are actually neo-Nazi sympathizers.

Elsewhere in Africa racist ideologies have flourished. In 1973 Eugéne Ney Terre'Blanche and six other far-right Afrikaners formed the Afrikaner Weerstandsbeweging (AWB) that had hoped to establish a Boer state. Initially he called for armed struggle and revolution, and was imprisoned for three years for attempted murder, and was himself murdered in 2010. Louis Theroux's BBC documentary on the Boer leader popularized the figure, who perversely constructs white people as victims of oppression, with 3.5 million white people versus 40 million black people in South Africa. His influence should not be seen in isolation, related merely to Africa, given his beliefs have influenced other white separatists. Theroux's style is to almost play an innocent fool normally, but in the episode of Louis Theroux's Weird Weekends called 'Boer Separatists' (season 3, episode 3), he does confront the man's racism.

Latin America is a significant zone concerning Nazi and neo-Nazi activity and its interpretation in a variety of media. Legends and myths blend with facts with stories about contemporary politicians meeting with active neo-Nazi groups merging with myths about areas internationally where neo-Nazi activity continues, constructed as part of occult behaviour. Peter Lavenda in Unholy Alliance: A History of Nazi Involvement with the Occult explicates the research he carried out in Chile and how he discovered a cult compound called Colonia Dignidad, described as housing a sect that combines Nazism and voodoo. While it might seem farfetched to assume that neo-Nazi groups globally were and actively are still engaged in the occult, a brief glimpse at the origins offers some insight. Thule Gesellschaft was a pagan anti-Semitic aristocratic society, founded by Baron Rudolf von Sebottendorff. He approached Walter Nauhaus, a veteran of World War I and the Thule Society was formed. Their focus was on racial evolution, Nordic mythology and German nationalism, and one interpretation is that this society gave birth to Nazism. They recruited among Germany's working class, by forming a group called the German Worker's Party, which met regularly in beer halls to discuss the threat of Jews, communists, and Freemasons. This group later became the National Socialist German Workers' Party (the Nazi Party), and in November 1923, they made their first attempt at a national takeover, the failed Beer Hall Putsch, led by a 
man who had originally been sent by the German Army to spy on them, Adolf Hitler.

Due to investigations made popular via blogs some of the myths around this subject situated in Latin America are more easily unearthed, debunked and tracked. Generally, it is well-known that some Nazis left Germany and entered Latin American society, living anonymously in places like Chile, but what is less known is that National Socialism was established in Chile prior to World War II. Memories of this are celebrated annually even today. Each September a pilgrimage is made to a monument in Santiago's General Cemetery, which concerns paying homage to an attempted coup in 1938. This coup was by young Chileans, many with German heritage, who were then killed by government troops. Since 1938 the support in Chile has grown. In the south, a German enclave that was complicit in the torture of the Augusto Pinochet regime lost its leader following charges of child abuse. Years of living under the vicious regime of Pinochet resulted in the flourishing of neo-Nazism in Chile, a country in which young people were willing to embrace an identity formulated around the notion of militarism.

There is a vigilante element to this. Peruvians who may be from a lower economic group are targeted by the neo-Nazis, as are homosexuals, drug addicts, and anyone perceived as different. There is an even earlier history to this. At the start of the twentieth century, Nicolás Palacios published the book Raza Chilena, and the ideology propounded in this text is still adhered to. Palacios, a criollo (a person of full or near full Spanish descent born in Latin America), popularized the belief that Chileans were the chosen race, a group formed from a blend of Native Araucanos and Spanish blood. ${ }^{6}$ Stepping outside of the Chilean environment, we can witness the absurdity of neo-Nazism when we consider Peruvian neo-Nazism. The leader of Peru's far-right political group seeks to expel the country's small Jewish population, believing they control the global economy. This is a common theme of Nazism and neo-Nazism. Claiming the system is being controlled by a bunch of evil people who are Jewish has been central to anti-Semitism, and has had a global impact. Hitler's hatred towards the Jews stemmed from this belief, and the view that Jews controlled the governments of all the countries he wanted to defeat. The iconography around Nazism and neoNazism and its absorption and mediation are central to its global impact. Martín Quispe Mayta, the leader of the Andean Peru National Socialism movement, admires Adolf Hitler and his office is adorned with portraits of the Nazi dictator, as well as well as a copy of Mein Kampf and a large flag bearing a symbol that looks like a swastika. ${ }^{7}$ 
Mayta, who drew his inspiration from Hitler's Nazi ideology as well as Henry Ford's anti-Semitic book The International Jew, further claims that the leader of Spain's brutal conquest of Peru, Francisco Pizarro, was a Jew. 'The Jew Pizarro and his band of genocidal Jews killed millions of native Peruvians in their mission to possess our gold,' he told The Guardian. There are only about 5,000 Jews in Peru, of a population of nearly 30 million people. In a place whose political and economic power remains largely in the hands of a white elite minority, with indigenous Peruvians at the bottom of the socioeconomic scale, it is the Jews who are, once again, blamed for the country's grievances. The Jewish Association of Peru said in a statement to The Guardian that it rejected Maytam's 'open expression of anti-Semitic racism', and had 'appealed to authorities to take the necessary measures to halt the incitement to racial and religious hatred'.

As a brief survey reveals, from Taiwan to Peru, the global impact of Nazism and neo-Nazism is clear, and the manner in which the media may invent and reconfigure Nazi and neo-Nazi stories tangible. As with some of the media, it would also be tempting to blame Donald Trump for every atrocity, globally, but this ignores history. Trump has been perfect for satire, despite the comedy so far not seeming to have any real impact. As the laws of transgression dictate, Trump might be mocked, but this only goes to reinforce his desire for a control on channels of information, which includes the media as a whole. Since taking office as president up until March 2017 there were over one hundred attempted bomb attacks on synagogues and Jewish-related centres in America. Globally, anti-Semitism has often been prevalent. A decade earlier, in 2007 police in Israel had thwarted a neo-Nazi ring, after an eighteen-month investigation. This was after attacks on two synagogues. The powerful significance of Israel in international politics should not be underestimated.

Since 1990 a million people from the former Soviet Union have emigrated to Israel, which has a population of 7 million. Israel's Law of Return allows anyone to claim citizenship if they have a Jewish grandparent, but a significant number of the new immigrants have no connection to Judaism, moving purely for economic reasons. Again, who is the victim is an interesting debate, with Russians believing they are discriminated against, being denied the right to marry. The police found explosives in the home of one of the suspect with plans to hold a Nazi ceremony at Yad Vashem, the Holocaust museum in Jerusalem. These events had wider ramifications. While Effi Eitam of the National Religious Party wanted a bill to restrict the rights of non-Jews emigrating to Israel, an Arab member of the Israeli Knesset, Ahmed Tibi, raised the issue of the absurdity of Israeli laws. Extensive rights 
are given to Russian newcomers with tenuous Jewish connections, whereas Arabs who have lived in the region for generations are denied rights.

\section{International Nazi Hunters}

Media attention has inspired the drive to confront Nazis, as well as neoNazism now being a genre in international fiction and documentary filmmaking. One area that has received global popularly is that of Nazi hunters, a term invented by the media. Various figures are hunted down and exposed during a documentary, and often found to be living quietly and anonymously. The overall argument for the makers of these documentaries is that the hunt for Nazis draws media attention to a subject that some find unpalatable, and this has definitely enabled justice to be carried out. During the Cold War, former Nazis were utilized in the West to fight against the Soviets, and certain deals were made to protect people from prosecution if they cooperated. The Advisory Board of Clemency headed by John J. McCloy did commute the death sentences and reduce the prison terms of various Nazi war criminals. The activities of freelance Nazi hunters have become the subject of a plethora of dramas and books, especially hunters Serge and Beate Klarsfield who delivered SS officer Klaus Barbie to French courts in 1987. There was the difficult goal of having to incorporate millions of former Nazis into societies.

While the scale and international reach was incomparable, this whole area of pursuing state criminals was not just a problem Germany and related countries faced with the Nazis. We only have to consider a handful of Latin American countries to see the parallels. Ariel Dorfman covers this in his internationally successful play Death and the Maiden. The play premiered at London's Royal Court in 1991, and since then has been performed all over the globe and turned into an opera in 2008. The ubiquitous nature of the play, set in an unnamed Latin American country, means it has had an appeal in a variety of contexts. The play was adapted for a film directed by Roman Polanski in 1994, starting Sigourney Weaver and Ben Kingsley, leading to worldwide acclaim and media attention. In the play a woman encounters a man who she believes was once her torturer under a dictatorship, but there are questions over truth and memory.

There is the subtext concerning gender, power, and collusion. In one interpretation, the play seems to ask: are we ready to confront the past, individually and as a nation, even if we are confronted with it? Rather than have figures hunting down a man, who may have tortured them in the past, 
here he appears by what seems like a random accident, following a problem with his car. This almost implies that life is actually far more random than we think, but we are always haunted by the past, whether we choose to confront it or not. Fundamentally, once you have been tortured, do you have the right to torture your torturer, or does this make us just like them? This question brings us back to the question about whether every one has the potential to be a Nazi. If this is the case, does this partially explain the ongoing fascination with neo-Nazism and related movements?

Sometimes the media collude with investigators who are outside the framework of the state, and by doing so can often achieve better results. Looked at cynically, we can assume this will create better drama through transgressing normal paradigms and structures. Rules are broken to attain a result, perhaps, or some form of accepted boundary transgressed. As with all forms of investigation, often the end justifies the means. But when people take justice into their own hands we should be concerned. This is even if they are partly justified, as in Death and the Maiden, where there is still ambiguity. There is a wealth of literature and research on the way private activists have made it their objective to bring Nazis to court, and the suspected crimes of these people go beyond anti-Semitism. As with the neo-Nazi film, the Nazi hunter documentary is a genre in and of itself.

These activists and hunters are arguably bringing about a greater sense of humanity, given those who have acted against humanity are being held to account, but sometimes they use methods that are inhuman. This is an international phenomenon, with the victims and perpetrators part of a diaspora that occurred during and after World War II. With documentaries about wars, and particularly about the Nazis, dominating channels, one with a live thread concerning a hunt was bound to create far more tension, having now become part of the zeitgeist. A subtext is this is a part of a new politically correct world, seeking transparency, by flushing out old evils. But there is an obvious parallel here with fascism. There is an alignment here paradoxically with racist ideology, which wants to cleanse the state, with the hunters wanting to remove evil from the world, to restore 'true' humanity. Justice needs to be done, but the close link to how this is documented and mediated via a variety of sources is of significance.

The media began referring to some of these seekers after justice as 'Nazi hunters', but pursuing Nazis was but only one part of range of activities. ${ }^{8}$ From the position of the influence of the media, there was a demonization that frequently removed culpability. Through some documentaries, people began to question the efficacy of using these methods. On the one hand, it was important for documentary teams to track down Nazis who had 
blended back into society. On the positive side, these individual agents also insisted that the courts and police live up to their duties. They co-operated with these agencies on various levels, during the investigation of the crimes in question. Actively coordinating media campaigns to educate the public to their cause, while fully explaining what they were doing and the historical framework, this indicated the real benefits of the media in this context.

Creating media programmes with this kind of content has become standard, from hunting Nazis, to paedophiles, to cheating partners. The 'money shot' here is the moment the person knows they are caught and cannot escape, like a caged animal after the hunt. The problematic nature of the Nazi hunters is the time it takes for this to go through the courts, given the people involved are elderly. Nazi hunting in some respects can be framed as a professional business, but still the legal process serves a function here, making sure all the evidence is weighed up. Often debates in the wider narratives come down to whether someone was aware of the deaths happening around them, or was just a functionary, or if there was an ulterior purpose if they helped some Jews escape. All of these stories make good material for documentaries or fictional films, as they involve unearthing a secret or solving a mystery.

We have seen how the film Inglorious Basterds plays on this theme in a historical context, loosely juxtaposing an initial hunt for Jews with a later hunt for Nazis. Either way, it needs to be noted that framing this activity as a hunt constructs humans as animals, and positions those doing the hunting as predators. This in itself might be a true reflection of reality, with the acceptable view that humans are just animals, and the hunt functioning as a trope for the capitalist system. Nazi hunters may have helped prompt changes in the political and juridical handling of the Nazi criminal legacy and also influenced the public perception of it. But a very real question remains over people taking justice into their own hands, and the status of the vigilante within the law. Their involvement facilitated the investigation of Holocaust crimes and served as a corrective throughout and the publicity the private activists generated instigated a wider discussion about Nazi crimes. ${ }^{9}$

Media forms may have helped make the boundaries and taboos surrounding the Nazi past more visible, shifting or overcoming taboos, but there were issues with crimes being distorted. As individuals gain the ability to create media products themselves, via personal documentaries made with handheld technology, we should not underestimate the value of individuals taking control of the processes of creating media. At the same time, often what appears in some contexts is beyond the hands of 
the maker and consumer of the product. For example, large companies advertising on Google have complained about the positioning of their adverts, sometimes these appearing against neo-Nazi websites and YouTube channels. Concurrently, outside the law any manner of uncontrolled events can occur, including uncontrolled violence against suspected Nazis, who actually may not be Nazis at all. This violence was frequently the case with regards to the battles between neo-Nazis and the Anti-Nazi League in the 1970 s and 1980 . The hardcore dedication of Nazi hunters globally has tended to highlight its value, especially the input from the media. While the rest of the population, along with governments, may have wished they could move on from the past without addressing it, these activities help societies to confront their past authentically.

Simultaneously, these hunts have conjured up myths and legends around where Nazi groups are living now. Helicopter shots of swimming pools in Latin America supposedly containing swastikas is just one such nonverifiable source, that generates this idea that in certain zones criminals linked to the evils of the past are being kept. There is also the implication that state investigations are not doing their job, and that only private individuals can get to the truth, which is not accurate. Transnationally, to position this evil always elsewhere serves a purpose of removing the evil from a known locality, making it always one step removed, and never containable. The most well-known example of the capturing of a Nazi by international state activities was that of Otto Adolf Eichmann captured in Argentina by Mossad, the Israeli intelligence service, in 196o. Eichmann was a major figure, given he had been responsible for the strategy concerning the deportation of Jews to concentration camps. Eichmann denied nothing, but claimed he was just following orders, and was executed in Israel in 1962. What the trial did was bring attention to the debates concerning culpability, with some historians arguing that not even Hitler called for the extermination of the Jews.

Other famous cases have been part of a series Nazi Hunters broadcast 2010 to 2011, and reveal the international scope of this exercise of hunting Nazis. Episodes include: the work of Serge and Beate Klarsfeld, who tracked down Klaus Barbie, known as the 'Butcher of Lyon', and had him extradited from Bolivia to stand trial in France; finding the Gestapo officer Erich Priebke, who was tracked down by American journalists in Argentina; the case of Josef Mengele, tracked for 30 years by Mossad, and who ended up moving from Paraguay and then to Brazil, where he died; hunting Paris Gestapo chief Kurt Lishka, who was living freely in Germany and then was arrested in Cologne, after being tracked down, again by Serge and Beate Klarsfeld; the 
complex case of Paul Touvier, who murdered Jews and resistance fighters in France; the hunt for Franz Stangl in Brazil by Simon Wiesenthal, which then lead to the arrest of the deputy commander of the Sobibor extermination camp, Gustav Wagner. These stories are packaged as real-life detective stories, and moulded within that genre.

Along with these real stories with tangible and intangible outcomes, there is a range of other media and cultural forms, such as the film Weresquito: Nazi Hunter (Christopher R. Mihm, 2016), which concerns the aftermath of a World War II experiment in the context of hunting. The film, like so many others, reveals how using Nazi themes becomes a simple way to develop a backstory in the context of 'absolute' evil. Soldiers are left transforming into blood-sucking killer insects at the sight of blood. The path to salvation is finding the culprits who committed the experiment and bringing them to justice. With an estimated budget of $\$ 10,000$ the tagline is 'The most controversial movie EVER made!' What this film and others media products suggest is that internationally, far from global cultures denying the Nazis, from fashion in Japan and Peru, to the transnational style and flirtation with fascism engaged with by David Bowie and his transnational followers and emulators, elements of Nazism and neo-Nazism have become ubiquitous.

Nazis and neo-Nazis hunting their enemies, and vice versa, is a subject of numerous films, globally. In Australia, it was Russell Crowe's breakthrough role as the lead in the film Romper Stomper that marked him out as a formidable screen actor. As with Tom Cruise and Daniel Day Lewis playing people with disabilities, it seemed the more realistically you could embody a neo-Nazi the more your credibility would grow. Similarly, in the German/UK film I.D., previously mentioned, when Reece Dimsdale played a neo-Nazi (John), he was arguably at the height of his career, the film gaining a cult status, with spin-offs and remakes, being distributed on various new platforms. In ID2: Shadwell Army (Joel Novoa, 2016), for example, the international scope of what was originally a seemingly very English film is made clear. Now a young British Asian policeman goes undercover, with Shadwell FC, owned by a Russian oligarch. What he finds is a battle between the EDL and BNP, political and football violence combined.

\section{Video Games and Conclusions}

Video gaming is also a significant area where Nazi and neo-Nazi tropes are reimagined. Regardless of the actual ownership of games, due to their interactivity, there is often a wider influence of video games regarding 
their impact with a global reach. A whole culture has built up since the 1980 s around the use of video games, which is a highly competitive field with its own rules. Concerning influences, it is also important to stress that various studies on the influence of video games need to be understood holistically. Video games frequently place the player in the position of a first-person narrator, or from the player's point of view. Some are still quite traditional in structure, drawing on forms such as the book, having chapters and characters.

When considering influence we need to be careful. No one single area of entertainment can be said to have constructed someone's identity and belief systems, or influenced their behaviour, despite moral panics about the use of video games amongst the young. Moral panics normally originate among those who have not engaged with the thing of concern. In this case, these games often offer a strict moral framework and are hardly transgressive. The relevance of a brief mention of video games here concerns their strong global appeal. Gaming is an international phenomenon and often transcultural. Arguably, unlike some literature or films that may alter in their translation, video games can cross these national and cultural boundaries easily, and are made with this intention in mind.

Stereotypically, video games concern the elimination of enemies in a variety of environments. But there are interesting low spec games that play on moral decision making that reflects preconceptions regarding race and nation. Papers, Please created by Lucas Pope and released in 2013, is an example that functions philosophically on a number of levels, set in a border zone that reinforces national boundaries. Here the player is an immigration officer in the fictional country Arstotzka, working in an airport, who gains points depending on their efficiency, but moral conundrums arise. If one of your clients tells you the next person in the queue is a terrorist, for example, do you take this as a diversionary tactic to obscure their own guilt, or act on this, but lower your efficiency rate overall?

The Nazis, of course, are almost like a global 'brand', recognized in most cultures. Having a Nazi thread to a game's background narrative appears natural, as then they are understood, with the tropes and signifiers already existing to draw on. Critics may conclude, as they do with some filmmaking and literature, that this overreliance on Nazi signifiers is uncreative, always returning to a set view of the past, but it would be difficult to cast this allegation at the work of influential authors such as Philip K. Dick. Video games, similarly, have often taken the same route, and used the Nazi era as just a stepping-stone for something much wider, metaphysically. The game then is actually a form of mirror to some of the pressing issues confronting 
the world during the contemporary period within which it was produced. This then informs the debates around neo-Nazism.

Even with the advent of postmodernism, critical discourse on video gaming is not as well regarded as it is on other forms of media and culture. Concurrently, the use of video games has always been considered as being slightly transgressive, part of an uncontainable youth activity that stands juxtaposed to the adult world, with its defined rules and regulations. As explained, video games do have their own rules, however, not only within the basic algorithms of their own software, but in the individual and social behaviour surrounding their use. We have the moral elements placed into video games, as in some versions of Call of Duty, where the user is being asked to survey what they have done, and reflect on their choices. This confronting the player with their choices does make a real impact. Call of Duty began in 2003 and had thirteen different versions by 2016 with its third incarnation having the allies fighting against the Nazis.

Caveats need to be added before a claim is made on the absolute international relevance of these games. The absolute need to win and beat the game is part of an adrenalin-fuelled experience that functions to create a personal sense of achievement, which may have more relevance in some cultures than in others. This is then self-perpetuating, and marketing of the same brand of games fulfils this function. There is an appeal that comes from placing the player within a visceral immersive first-person perspective, which goes beyond the passive consumption of the culture that the older generation can be accused of. Given the significance of Nazism in history, it would be strange if a number of video games did not have this theme as their backstory.

Whether it is fighting Nazis or demons, these games operate in a postcivilization world, which reflects on a position promoted in cultural theory from the 1980s concerning 'the end of history'. The title of Slavoj Žižek's 2011 work Living in the End Times sums this up. Life as we know it in reality is not functioning anymore. This whole 'beyond civilization' scenario is actually akin to much of the Nazi doctrine, which wanted to bring about the end of one era, and the instigation of another. Beyond the rhetoric was a belief in the march of history, and that this was part of destiny. Similarly, it is neo-Nazi ideology that maintains civilization is being damaged by the acceptance of immigrants, for example, and it is time to 'refresh' the world. The Turner Diaries makes this clear.

Section 86a of the Criminal Code of Germany prohibits the use or depiction of unconstitutional organizations, and the video game Wolfenstein has been included in this ban. In its post-World War II scenario, the Nazis have 
won the war via robots, and variations on these games involves hunting down and killings Nazis. Having an enemy has virulent as the Nazis makes any game more enjoyable, and so criticism that such games lack imagination is disingenuous. Hundreds of games involve traversing a difficult terrain, being chased or chasing, in some ways hunting bounty. Again, we might return to Freud's notion expounded in his explanation of his grandson's fort/da game, where the interpretation is the 'player' is dealing with their relationship with their mother. Freud's grandson throws a cotton reel, pretends it is gone, and then retrieves it, the game working as a form of psychodrama, reassuring him about his mother. The same can be said for video games.

Wolfenstein: The New Order, according to www.vgchartz.com, sold 1.56 million units by 18 February 2017. Breaking this down internationally this is split 30.7 per cent in North America, 51.6 per cent in Europe, 2.1 per cent in Japan, and 15.7 per cent in the rest of the world. Set in the 1960s, the series involves the protagonist B.J. Blazkowicz, who launches a counter-offensive against the Nazis, who have taken over the world. This game was the seventh in the series, originally released in 2009. The game received numerous awards, globally, indicating how its transnational themes, including the aesthetics, were appealing. As early as 1981 Apple II offered Castle Wolfenstein, which had the player search for secret war plans, but it later switched to first-person shooting. By 1993 the successful Wolftenstein ${ }_{3} D$ was causing controversy. Opening with the Nazi Party anthem 'Horst Wessel Lied', the game involved the player making their way through swastika-smothered bunkers, killing Nazis in an attempt to find Hitler. Banned by the German government, attacked by the American Anti-Defamation League, the game led to evolution in the field, influencing a new generation of games. ${ }^{10}$

Through documentaries the media created the term 'Nazi hunter', and this then inspired the creation of video games, films, and galvanized further interest in Nazism, internationally. Stating anything is universal is contentious, given it may offer collusion with a certain violence of colonialism, where the European truth or value is defined as the universal one. This chapter has briefly explored certain regions in the world where neo-Nazism proliferates, and stressed how certain attempts to address racism can be in itself be termed as re-inscribing the notions of race and purity. The paradoxes concerning immigration and diaspora, especially in a Turkish context, are significant and reveal how a group with neo-Nazi similarities has thrived on violence. A number of groups within certain countries that feel threatened by global powers that then turn to neo-Nazism have been surveyed. The importance of Donald Trump's dominance through the media has been 
shown to indicate a unification of disparate fascist support around the globe. The obsession with purity and origin is then disseminated through various media platforms. This is then tied into neo-Nazi ideology, leading sometimes to violence, offering believers a sense of power. In Latin America, for example, this related belief system in a different form existed prior to Hitler's physical expansion of Germany. Overall, this suggests these beliefs are transnational in appeal and scope and have longevity, through hardcore believers claiming to adapt their beliefs to become more mainstream, and followers functioning as local enforcers of tradition. 



\section{Conclusions - The Infinitely Other}

\section{Evil and Violence}

From 1990 to 1997 seven and a half million foreign-born people entered America legally, forming 29.2 per cent of the population growth. ${ }^{1}$ Globally, many white people sincerely believe their rights have been overlooked, and this victim status as the 'new other' then lends them a level of respectability which right-wing groups have capitalized on. Some German neo-Nazis took this position after World War II, arguing the treatment of Germany by the allied forces gave them this victim status. The discourse around books on hooligans, such as The Football Factory and various spin-off television series, claims that the white male has been overlooked in general. There is little nuanced analysis over how male violence is still a problem, especially domestic violence. Often racist violence in this context is given overt approval as a form of legitimized retaliation. The terms 'nationalist' and 'populist' replace the concept of 'extremist', and yet it is still extremism, and in some cases terrorism. In controlling the discourse by constantly branding the 'other' as a terrorist, often linked to a specific religion, any level of domestic terrorism can be carried out in the name of homeland security by the state. The state then commits acts of terrorism in the name of preventing terrorism.

Neo-Nazi groups have been quick to utilize social media for their purposes. Politicians like Donald Trump have thrilled in condemning the establishment. It is part of a general discourse to describe the current order as the establishment and the need for a new order as doing away with the old establishment. Adolph Hitler used it as a tactic. In Britain, the whole of Jeremy Corbyn's construction as a leader was to claim he is anti-establishment. Before the Liberal Democrats joined a coalition government, Nick Clegg gained support via live UK television debates by painting himself as an outsider and anti-establishment. Trump, with his personal wealth, was always part of the higher echelons of society, despite the ongoing vagaries around what we mean by class. Clegg had gone to a school of the establishment, which made him part of the establishment. As Stuart Price has explained, the term 'working class' has been weakened, with regards to a positive political identity; simultaneously, the other large category, the bourgeois class, has been challenged. This is exemplified by the growth of managerialism matched with precarious employment practices. ${ }^{2}$ There is the significance of the development of the use of technology which needs acknowledging, robots replacing labour, creating a labour-free class. 
Whether neo-Nazis are part of the establishment, those that control the media fuel neo-Nazi arguments, which are normalized. No one could argue seriously for any direct hypodermic model of media impact, but the shift to making extreme right-wing rhetoric part of the mainstream offers a platform within which people formulate opinions. This is regardless of whether these ideas make any rational sense, have long-term validity, and stand up to testing.

In the UK and in America in 2017 there appeared to be no actual plan or real strategy, no matter how frequently Donald Trump or Theresa May repeated 'we have a plan'. The media had taken a guiding hand in this chaos, with politicians since Tony Blair overtly guiding their policies in relation to how events were constructed by the media. Trump had taken this a step further, more preoccupied with how he was perceived than any other previous politician. If the media was not supportive of his strategy, or lack of it, then they were condemned as spinning fake news controlled by his opponents. Satire and mockery did not dent Trump's agenda. Simultaneously, the media itself was condemned by Trump as being part of the establishment, a normal tactic that politicians have employed. This condemnation appeared to be working. Trump was continually shown to be lying over various issues, but initially the media was silenced and condemned as being false and fake. To paraphrase a well-known phrase from George Orwell, in a world of lies speaking the truth is revolutionary.

The emphasis on Trump is so relevant because internationally America was still regarded as the leader of the 'free world' in 2017, despite becoming anti-international under Trump and the phrase now appearing antiquated. Trump's use of the media was highly selective. This could be conceived as censorship and was also a theme former UK Prime Minister John Major had touched on when he pointed out that anyone thought to hold an anti-Brexit position was being condemned as being anti-British. In February 2017, the BBC were not allowed to take part in a press briefing by the White House. The BBC challenged this decision, which became a news item in itself. This highlighted how information was now being selectively disseminated to those who would not challenge or question the approved message. Repetition of key messages, regardless of their veracity, became the norm. During Hitler's rise to power he initially advocated brute force, but then realized he had to win people over through the system, and closely manipulated his own image for these purposes. In this regard, it would be wrong to suggest Trump was the arch-manipulator of the media beyond anything seen previously, given Hitler's prowess. Unlike Hitler, however, Trump could reach the world instantly and directly through Twitter. 
In America, scholars often use the term 'radical' for some extremists, which is almost a compliment. At its heart is the constant threat of the 'other'. There is also a complexity concerning the relationship with the establishment. Whether you are a white separatist, a survivalist, a KKK member, or a neo-Nazi, you have the same ambition: ridding the earth of any non-white race. How far this goes is continually open to debate. White separatist movements existed before the Nazis, and so labelling all these movements 'neo-Nazi' could be questioned. During times of austerity, those with the most powerful voice, utilizing whatever media they can find, will turn the population against free thinkers. What we find within this discourse is an attack on the educated, those who have the ability to challenge the system. They are demonized as the elite, damaging the position of 'real' people. Once again there is the manufacture of the myth of authenticity and purity, with a continual harking back to a utopia that never existed. The films of Steve Bannon are random and irrational, but have the central theme that there was shift during the progressive and liberal 196os that attacked the so-called real and pure America. Within this ideology, this is what led to its downfall and must be counteracted at all costs. Myths are then created to serve a purpose.

In his seminal early book Hitler: A Study in Tyranny (1952), Alan Bullock showed that Hitler, despite myths to the contrary, was not from a poor or uneducated background. His father was an established customs official, and his pension continued after his death. Hitler pretended in Mein Kampf that he had a poor education, which again was false. He did leave school in 1904, not because he was too poor, but because he was indifferent to education, finally leaving without any certificates at all. He may even have completed a short course in marketing at the University of Munich. When Hitler left prison after writing Mein Kampf the global media reported that he was a reformed main, who wished to retire into anonymity. Regarding education, Trump is well-known for a court case over his Trump University, where he was sued by former students, who believed their fees were wasted on get rich property courses that had no basis in fact and were unethical. While Trump personally could be labelled an extreme capitalist, the epitome of a certain kind of American greed, calling him a radical or an extremist is suggesting he personally has a wider political ideology, which is debatable. But a basic review of Steve Bannon's propaganda reveals a very clear ideology.

Hitler was in some ways preaching to the converted, as was Donald Trump in 2016. Prior to Hitler's rise to power, there was the belief that hundreds of thousands of Jews were going to attack German girls, and that 'Negroes' were a threat to German purity, fears more recently drummed up with 
regards to Muslims. The similarities in rhetoric between the regimes are uncanny, and debates rage on whether Trump is akin to Hitler, or whether that argument is overblown. Even diametrically opposed ideologies can use identical rhetoric, as with the Osama Bin Laden and George W. Bush's speeches. ${ }^{3}$ Trump's blustering rhetoric in his campaign and since he gained power focused on war, a sure way to galvanize those who feel they have been mistreated, and who seek revenge. This was essentially a war against liberal elites, a war against immigrants, and a war against the rest of the world, who apparently hated America.

According to Nietzsche, war is a state that ennobles mankind, and Nietzsche can be used to explain the theological concept of Judgement in post-9/11 theology and public rhetoric. Both Bush and Bin Laden used forms of vengeful sermonizing, as has Trump; there obviously would be no President Trump without 9/11. This emphasis on war, again, is nothing new. For Trotsky, war was the locomotive of history. William Gilmore Simms, a poet, novelist and historian from the American South of the nineteenth century, explored the following view: 'War is the greatest element of modern civilization, and our destiny is conquest. The moment a nation ceases to extend its sway it falls a prey to an inferior but more energetic neighbour. ${ }^{4}$ American foreign policy appears to cohere with this view. In Trump's case, as well as Islam, the enemy was switched from the Jew to the Mexican initially, with strong claims they were rapists, hence the need to build a wall. In Steve Bannon's films the covert attack is on Jews. The wall itself was not Trump's idea, and had already existed in part across some of the Mexican-American border. For example, the city of Nogales has an existing wall that is eighteen feet tall dividing Arizona, USA, and Sonora, Mexico. ${ }^{5}$

The Department of Homeland Security patrols the wall, which advanced its militarization after the attack on the Twin Towers in September 2001. In southern Arizona, between October 2000 and September 2014, there were 2,721 people found dead, from a variety of courses, plus numerous others were not discovered, trying to enter America. Arguing which country, America or Mexico, is superior, is a false question, and relates more to fiction than fact. Because the space travelled to is outside the space travelled from it is a "nowhere, place without place [...] the syncopation of an infinity and paradoxically its limit, its frontier. ${ }^{6}$ Trump's views on miscegenation have a very long history and stem from a great deal of fictional literature. H. Rider Haggard in Heart of the World (1894) portrays union between races as causing destruction. This myth is one used time and again in Europe and America by the far right. One even more metaphysical question is: Which country, America or Mexico, is the land of the free? Americans seeking 
escape see Central and Latin America as the zone of freedom. This was cultivated by a generation of writers and figures linked to a number of movements, including the Beat Generation.

In the run up to World War II, propaganda worked at home and abroad, with British papers such as The Express denying Hitler was a threat, and claiming there would be no war in Europe, even when Hitler was invading Poland. The media in general was in denial. Ownership of these papers was in the hands of Nazi sympathizers, and whatever activity he did initially was justified. Fundamentally, Nazism, like neo-Nazism, is based on long-held grievances. For the former, it stemmed in part from issues over the Treaty of Versailles, and the manner in which Germany lost territory, along with the high reparation payments forced upon them. Hitler, along with other Germans, believed their grievances were justified and they had been harshly treated. For neo-Nazism, grievances are linked with the perceived loss of identity and opportunities, with groups of 'others' to blame. From jobs, to houses, to women and children, the evil other is portrayed as stealing from and ruining the motherland. In America, Trump claimed Mexicans were raping American women. In the UK in the 1930s the newspapers were full of the apparent sex crimes committed by Jews. ${ }^{7}$ How much these were believed is questionable but we can see a parallel today with the discourse on immigration, especially in Germany. When repeated frequently enough, propaganda will be taken by the people to have some basis in fact. The evidence of its influence is debatable, but the message worked in Trump's case.

The notion of purity has a long history. A German girl may become pregnant, and a non-Aryan might be blamed. This is also evidence of a threat concerning the power to reproduce. Makers of new technologies have had a problem with how they deal with hackers, those who are intent on subversion and disruption. What better way of subversion than using Hitler? An example of this came in March 2016 when Microsoft was forced to delete its teenage AI after it became a Hitler-loving sex robot. On 16 January 2016, The Mail Online reported on 'The Backlash:Neo-Nazis on the Rampage'. Apparently gun sales were soaring. Sue Reid warned that sex attacks by migrants had 'unleashed dark forces in Germany that have echoes of the past'. For The Independent, reporting 13 February 2016, the Cologne sex assaults were part of a Muslim rape myth which fitted the neo-Nazi agenda. On 29 March 2014 the Daily News reported that the Neo-Nazi Party in Germany had dropped porn star Ina Groll, after discovering she had previously had sex with a black male. Issues over sex crimes can work both ways. On 14 April 2016, the campaigning organization 'Hope Not Hate' reported that Ryan 
Fleming, a British neo-Nazi on the sex offenders' register, had released a book, Codex Aristarchus.

The media were very keen to unite Nazis with paedophiles. For example, The Daily Record reported on 7 May 2016, 'Nazi Thug Who Chanted Allah Is a Paedo - Is Exposed as a Child Sex Pervert', naming Kristopher Allan as an active member of the Scottish Defence League. In Russia and America there have been cases of neo-Nazis taking justice into their own hands, and in using violence in brothels. On 6 August 2016, The Inquisitor reported Jeremy and Christine Moody plotted a vigilante murder of a sex offender. There have been many killings globally that have been tangentially linked to neo-Nazism, but the most well-known ones seem isolated from any group ideology. On 23 September 2008 catering student Matt Juhani Saari killed ten people and himself at a college in Kauhajoki, 180 miles northwest of Helsinki, Finland. The day before the police had been questioning him over videos he had released on YouTube, but they had released him due to lack of evidence. Hate crime over social media is a developing area and it is questionable whether the police would have just released him if this happened today. Five days before the murders his YouTube message claimed he hated the human race, and that his favourite video clips were the Columbine school shootings in Colorado.

We need to be cautious when connecting neo-Nazism to a variety of mass killings that occur globally, especially in terms of cause. Similar killings, such as those by Pekka-Eric Auvinen in November 2007, a student from a town outside Helsinki, who shot dead six students, plus the school nurse and the head teacher, before killing himself, suggests that neo-Nazi influences are just some of the beliefs that turn an individual to hatred. The point that these killers make is that this is an avenue to find a voice and achieve notoriety, but it should not be overlooked that the 'classic' example of this is the Columbine shootings. In this instance, after planning on bombing their high school in Colorado on Hitler's birthday, they instead shot twelve people after their homemade bombs failed to work. Postmodernism is key here. The Columbine killers wanted to be regarded as authentic killers, not copycat killers forming part of a wave of other killers, such as those at schools in Oregon and Kentucky. There is a strong argument that these killers are white terrorists, although their victims are not necessarily those from ethnic minorities, and some of the killers are from an ethnic background. Seung-Hui Cho killed 32 people on the Blacksburg campus of Virginia Tech on 16 April 2007. As Peter Conrad summed it up, referring to the current state where biology and technology have fused: 
Killing so coolly, Auvinen, Cho, Klebeld and Harris belong to a generation that has advanced into this uncanny existential future. They are certainly postmodern people, attempting to salvage what Auvinen calls a 'free mind' from the stale sameness prescribed by the media. But I wonder somehow if they're not post-human as well. ${ }^{8}$

Rightly or wrongly, this comes down to the issue of authenticity. Culture in part thrives on the ideal of authenticity, with the idea that to be authentic we must openly express all our rage, raw sexuality, and cruelty, even when this may fly in the face of cultivated morality. Figures such as the Marquis de Sade, Arthur Rimbaud, Georges Bataille, and Antonin Artaud, are all central to lifestyle enclaves and art movements of Western culture. Freud most famously revealed the darkness at the heart of the human animal. But the only way we can distinguish right from wrong is by having a moral map gained from socialization. These killers were anti-society, but they liked to believe they were original, when in fact they were its antithesis, acting out the roles they had seen in films, such as the influence of Oldboy (Chan-wook Park, 2003) on Cho. Even the witnesses had been so conditioned by violence on television and film that they failed to believe what they were observing was real.

Postmodern discourse should not be shut down. We see this in the work of Quentin Tarantino. Simulated violence is utilized, offering a postmodern parody that penetrates bland calls for authentic discourse. There are multiple paradoxes. Postmodern philosophers, such as Gilles Deleuze, argue that the best theory leads to more theory. This takes us beyond blinkered thinking. Those that attack such philosophy are looking towards the past, to a period which they believe was clearer, and more authentic. In reality, that pure period never existed, other than in the desired imagination. Black-and-white frameworks and paradigms may have been employed to promote structuralist thinking. The playfulness of the postmodern is more subversive to the simplistic paradigms of fascism than anything else. New media technologies, while often being employed by neo-Nazi groups, have also successfully added to this openness, offering a more fluid way to both present knowledge and opinion, and for people to construct and play out their identities. This can challenge power systems and destructive ideologies, including neo-Nazism.

One of the major concerns of those that believe the Internet needs to be censored is that it may be giving people access to illegal material or misinforming people, as well as all the other issues over child grooming. Worshipping death, attempting to make a monument to death through the 
virtual, posting on the Internet, killers, being 'real' neo-Nazis or not, and their followers, conversely wipe away the moment, the space in which an event can take place. While the Internet is a space with infinite possibilities, it becomes a scrapbook for images of nothingness. For Derrida, we cannot have our being without violence; using Levinas, he claims nonviolent language is language without the verb 'to be'. Usually, evil is said to be lies, ignorance, or deadly stupidity, all ways Trump has been described. Following Badiou, when we truly confront the condition of evil, we see it is much rather the process of truth. ${ }^{9}$ In relation to totalitarianism, there is always a desire for the omnipotence of the True.

There are further controversial elements to this subject we have only briefly touched on, and some of these relate to pleasure. What, then, are the ethics of Nazism and neo-Nazism as entertainment? The concept of the 'Holocaust industry' is well known, and Nazi chic mentioned in Chapter 1. Does this phrase industry also apply to the Nazism and neo-Nazism and the media? Is there an industry around the use of Nazism and neo-Nazism as entertainment? And, if so, what is the wider purpose of this in the media and for society? Categorizing media products as white power movies, or neo-Nazi texts, can lead to their promotion and better marketing. The study of characters in certain texts can be utilized for knowledge concerning 'the construction of subjectivity in the world' beyond the text. ${ }^{10}$ Similarly, these texts may offer indications in the apparent real world of how to behave.

The plethora of media that utilize Nazi and neo-Nazi-related themes are too numerous to address in one book, but the question of entertainment, as a whole, can still be tackled to a degree. The stereotypical savagery of the Nazis has a ubiquitous appeal for screenwriting narratives, given questions of otherness and conflict are always being addressed. Stories concern tackling a secret with secrecy at the very core of power. Despite being so reworked, the full knowledge of Nazism and neo-Nazism can still be viewed as a secret, which can never be fully uncovered. The area of Nazism and neo-Nazism is one of the most contentious there is, and is bound to draw attention from a marketing perspective. To complicate matters, this question of otherness can always be reversed, such as when the skinhead racist finds out he is Jewish, a theme in a variety of films. The creation of a belief in a force that must be destroyed plays with the notion of the sacred, and the imagination.

Hatred towards Jews within a Nazi and neo-Nazi context goes beyond the physical to the metaphysical, a realm that involves the invisible. The belief is their malign influence has caused a negative impact that is beyond that 
which is visible. In this regard, when examining Nazism and neo-Nazism and the media it needs to be understood that the frenzy of the visible which allows for a certain magical system. Paul Virilio in The Vision Machine declares that what we have in the media age is blindness, leading to a lack of understanding. But the question remains, Is part of the entertainment of the real a secret knowing, that this is, a playing with meaning? This can be illustrated by the Freudian fort/da game, inside the seen and unseen and the lost and found. In the position between the signifier and the signified, do we really allow and then enforce an ethical judgement and shut down engagement? Engaging with this subject is touching on transgression. By doing so, this is moving towards the sacred and the paranormal, between the physical and metaphysical.

There is a playing with secrecy and revelation, and the controlled transgression of the revelation similar to the workings of shamanism. The media creates our contemporary myths, functioning to some degree in this shamanistic fashion. Despite a healthy scepticism towards the media, there is still an addiction to its output and a certain belief. To allow play and to engage the imagination some belief, even if it is simulated, is necessary. As with all forms of terrorism, neo-Nazi violence is a form of entertainment, a way of focusing the eyes of the media. To call this white terrorism reemphasizes the spurious idea that white as a category has some form of authenticity, although culturally it does. Nazism and neo-Nazism has war as one of its tenets, and war itself is a theatre. Nazi accounts of engaging in war take on a religious and romantic tenor, while French reports of their defeat take on a paranormal tone, their failure described as a 'phénomène d'hallucination collective'."

There is a philosophy propounded by Virginia Woolf and others that has maintained that an event only really exists if it is recorded. What would we truly feel if we could see inside the Holocaust? A difficult question is whether this reminder of the Holocaust through the emphasis on Nazism and neo-Nazism in the media is actually an effort at doing so, at getting behind the Holocaust. Attempts such as Son of Saul, discussed in Chapter 2, despite their well-meaning worthiness always fail. While seeking authenticity may be a noble aim, it should also be remembered that this is impossible. Neo-Nazism is not just about ridding the earth of Jews, and even that aim might be questionable to some neo-Nazis. In its original incarnation, groups like the National Front in the early 1980 s in the UK were concerned with headline policies, such as repatriation and capital punishment. Nigel Farage's UKIP had some similar headline policies, forcing the main Conservative Party in the UK to always move further to the right 
to capture the support of the far right. Once more, the centre is then forced towards the extreme.

Farage was the first politician to be revealed by the media to be seen meeting with Trump, like a mascot of the new order winning the approval from the demi-god. Theresa May then going to America straight on the heels of this, and offering Trump a state visit to the UK within seven days of his inauguration, is clear evidence of Farage's influence. Time and again, members of UKIP have been under scrutiny, and found to be verging on the neo-Nazi right of politics. May's move legitimizes this. By playing the trump card of a state visit, which would be blessed by the Queen, in her authority May was asserting a triumph concerning class. May was using the status of royalty as a gift to Trump to gain his support, to subvert Farage's power. Despite his party previously winning a vast number of votes, nationally, Farage was not a UK-based politician. Underlying all of this was a class-based nationalism, and a yearning for identity. At the end of March 2017 UKIP had zero MPs, with Douglas Carswell resigning from the party.

Neo-Nazism is not at the extremes of culture but at its heart. A further question is, Can we consider this to be a new phenomenon? Only postBrexit and with Trump did people feel more comfortable expressing these views, the argument being they were always there. Optimistically, what we might see in America is the last roll of the dice of the extreme right, Trump known as the 'disruptive president', doing everything he can to create chaos, destroying any gains made by progressives. Steve Bannon's films are a prime example of media culture that attacks the notion of progress and equality. Our exploration of the television series NSU German History X also revealed how the extreme is at the centre of culture. Furthermore, media forms such as this Netflix series reveal that neo-Nazi belief has just filled a void. Those portrayed in this drama based on fact have no clear direction, and see the older generation as not just conformist, but also betrayers of the past. Once again, there is the view that they have been betrayed, and progress is detrimental. There is also the international element, with the National Socialist neo-Nazis in Germany learning their tactics from Americans. The programme makes clear that Muslims are the new Jews, although this argument has been shown to be contentious.

A question is also raised about education and the contemporary audience through these forms of media. For those not raised on detailed history lessons about the Nazis, these media and cultural products are their history lessons. Identification with groups to gain social acceptance and a sense of personal identity is fundamental to this analysis. For example could, theoretically, a programme such as NSU German History $X$ actually encourage 
neo-Nazi violence? Influence is a complex area, with no definitive answer. No amount of ethnographic work could make it clear that cultural product $\mathrm{X}$ was the reason for behaviour or belief Y. In January 2017, The Jerusalem Post reported a number of anti-Semitic attacks across the south-east of England, including bricks being thrown through the windows of Jewish people in Edgeware. Post-Brexit, post-Trump, and post-truth, it appears that there is an increase in actions that can be conceived to be neo-Nazi. Neo-Nazi groups often viewed biopics such as NSU German History $X$ as lessons in how to be a neo-Nazi.

One larger question concerns the issue of whether the actual context is important. For Tarantino, the issue is revenge. For Spielberg, the issue is forgiveness. In both contexts, however, there is the negotiation with the other highlighted by the face. For Levinas the face, 'is not biological, ethnic or even social; the face evoked is the concrete appearance of the idea of infinity that exists within me'. ${ }^{2}$ Film by its nature deals with this infinity, and working with Levinas we see that his philosophy concerns resisting possession or utilization, which is anti-Nazi, regardless of the meaning of the sign over Auschwitz: work sets you free. Taking this a step further, can we really take on a responsibility that transcends knowledge? As Levinas shows, the face signifies ethical knowledge, which is there from the beginning: thou shalt not kill. This again is anti-Nazi. There is a profound paradox here. There is in the face what seems like the impossible: 'It obliges us to receive the idea of infinity prior to engaging the operations of cognition, but how can we receive an idea prior to entering ideas?'13

Theodor Adorno claimed the Hegelian system objectifies the subject, raising it in the process to a transcendental status, but for Adorno the separation in philosophy between object and subject since Descartes is wrong, as they are mutually mediated by each other. ${ }^{14}$ For Levinas created being (totality) is but the trace of the passing of the infinitely other. ${ }^{15}$ 'It is not the self that constitutes the meaning of the Other's existence; rather, it is precisely the opposite: subjectivity is constituted in and through its relation with alterity. ${ }^{16}$ While seemingly complex and abstract, this needs to be held in mind when considering neo-Nazi discourse within the media, in all its varieties. 'One is not aware of his or her individuality until one enters into a relationship with Another [sic] and so calls the subjectivity of freedom itself into question. ${ }^{17}$ The Nazis destroyed difference, as do all dictators.

Donald Trump has been condemned for being divisive, and also for demonizing difference, but also simultaneously praised for uniting America via hate; over 60 million voters agreed with him enough to vote for him. 'Ethics, the welcoming of the Other [sic] by the self, is only accomplished 
through the recognition and maintenance of the radical disjunction of same and other, of subject and object. ${ }^{18}$ We need to recognize the importance of the infinitely other, that is non-containable. Fundamentally, it appears that the Nazi and neo-Nazi movements concern containing this otherness. To summarize, for Levinas, 'who was saved the fate of his fellow Jews [...] the violence endemic to sexism, racism, classism, nationalism etc., is the denial of the totality of being as the trace of the infinitely other'.19

\section{Denial and Memorial}

In February 2017 Channel 4 News reported on a survey concerning Internet searches that found that the top four items brought up using any search engine or platform regarding the Holocaust were basically neo-Naziorientated messages. People receive all their information from the Internet and despite it often being misinformation people will then believe that the existence of the Holocaust is debatable, for example. Even renowned Holocaust denier, David Irvine, in an interview with Channel 4, found this disturbing. He had tried to escape publicity by moving to a remote part of Scotland, but was still inundated with fan mail, from followers. The film Denial (Mick Jackson, 2017) was based on David Irving's 1996 libel lawsuit against academic Deborah Lipstadt and her publisher Penguin. Lipstadt had accused him in her 1993 book Denying the Holocaust of being a liar and Holocaust denier. Much of the debate focused on whether there were holes to place the gas into the chambers. The judge suggested that if Irving (played by Timothy Spall) truly believed his account then he was not lying. The drama of the film also focused on the conflict between Lipstadt (Rachel Weisz) and her lawyers. The lawyers were convinced she should not take to the stand, nor should a Holocaust survivor give evidence. Message boards on YouTube concerning the film's trailer were again dominated by neo-Nazi discourse in February 2017, with commentators arguing tautologically that if so much weight was given to disproving the deniers there must be some truth in their denial.

In a Channel 4 interview in April 2000, after the trial Irving argued that he did tell his version of the truth, and that he was not a racist. He blamed the media, claiming the media was obsessed with racism. He positions himself as an old-school patriot, claiming his views are that of the majority, which is a common tactic we find amongst the far right. Almost 20 years later, with the Brexit vote in 2016, Irving's form of racism became overt, suggesting he had a point regarding the majority. By this, I am not suggesting 
this is legitimizing these views, or that they are commendable. The judge had called him a racist, stating he had falsified the facts, mistranslated documents, and his perception of Hitler had basically led him away from objective history. Irving's view was that Hitler was basically innocent of the destruction of the Jews, because he was not fully aware of it. Concurrently, he claimed the death camps could not have been used for systematic slaughter. But discussing the trial with Krishnan Guru-Murthy, the Channel 4 News presenter, his arguments do not come across as extreme; he agrees that he has to be selective with the facts. With both the trial and the film the very real danger, as we saw with NSU German History $X$, was that this would fuel an interest in Irving's work, especially his website, boosting his popularity once more. Despite the truth, the paradox is this would strengthen neo-Nazism and anti-Semitism.

Irving called the judgement 'perverse' and had called Holocaust survivors 'mentally ill'. The tactic here is to condemn anyone who disagreed with you as morally or mentally inferior, a classic fascist device. A more common way today of doing this is to claim someone is 'on the spectrum', dismissing someone because they may have some form of autism or related different ability. Significantly, in America the burden of proof is on the plaintiff, but in English law the burden of proof is with the defendant. This gives the film Denial an opportunity to work as a history lesson, with Lipstadt and her lawyers going to Auschwitz and elsewhere to find further evidence. The film pushes the trial beyond Irving making it about preventing the rise of anti-Semitism, and neo-Nazism, and also about the importance of truth. The UK release date of the film is also significant; the film was released during January 2017 with Holocaust Memorial Day being 27 January. In America, it was noted that the White House issued a statement on the day which unlike previously did not refer to Jews and anti-Semitism. Some, like Jonathan Greenblatt, the CEO of the Anti-Defamation League, criticized the removal of explicit references, but the argument by the new administration was that this was an ecumenical statement.

In the age of Donald Trump, all media outlets became obsessed with the fake news phenomenon. Channel 4 ran a whole week of debates on the subject in February 2017. Commentators who were not exactly supporters of Trump but were attempting to stay outside the mainstream claimed that this phenomenon of fake news had always existed, and was the paradoxically the essence of news reporting. Altering reality, then reporting it as fact, has an old history. David Irving, for example, in his work in the 1960 os on the bombing of Dresden, claimed that over a quarter of a million people were killed. The impact of this hyperbole is of note, and reveals how so-called 
knowledge is generated from no evidence. Future histories took this as an absolute fact, until two decades later it was found irrefutably that Irving was a fabricator. The judge in the Lipstadt trial pointed out that Irving was not using documents correctly. Irving's increased the number of deaths in Dresden by 1,00o per cent. Irving's early work, taken as historically accurate at the time, was an international best seller. This then had such an influence on belief about World War II that the allied forces in this context were then believed to be the savage aggressor, killing a quarter of a million innocent civilians just at Dresden. The figure now is to thought to be more like 20,000, but in popular debates the view that the allies were as brutal as the Nazis is still held. Trying to dismiss such views as untruths leads to counter-allegations of denial, despite their being no evidence for Irving's arguments. Once such views have been absorbed into the history books it is difficult for them to be retrospectively edited out.

With the amount of rolling news and information on the Internet, the speed of breaking news stories can take precedence over accuracy, especially if the number of gatekeepers is reducing. Neo-Nazi groups globally have been successful in utilizing Facebook and other forms of social media to spread their message. It would be wrong to conclude that just because someone reads a neo-Nazi site, or watches a video posted by Britain First, they are a follower of this ideology. The British Labour Party, itself accused of being anti-Semitic, possesses the largest membership of any party in Europe, but stands in diametric opposition to Britain First. The 2016 London mayoral elections epitomized this, with the winner being a Labour politician and a Muslim, Sadiq Khan. In November 2016, The Daily Star reported a neo-Nazi group was calling for Sadiq Khan to be assassinated. The story was linked to the killing of Labour MP Jo Cox, and claimed the extreme-right forum IronMarch had postings demanding: 'Now kill the London mayor.' The administrator of the site was Benjamin Raymond, leader of National Action, a splinter group of the British National Party's young wing. Other serious neo-Nazi-related attacks have occurred in the UK, with Zack Davies being jailed in 2015 for his attack on an Asian dentist. Davies was also a member of IronMarch with links to National Action. The drama concerning these events is central to the debate, conflict key to grabbing the audiences' attention, the news media a form of entertainment. Examples include El Niño Skin, who was arrested for racism on 19 February 2015 and became a hero as he was perceived to be livening up a sports game.

Crimes connected with Nazism did not disappear over time, but were in general bought to light further. The Associated Press reported on 13 November 2015 that Oskar Gröning was charged with 300,000 counts of 
accessory to murder. This was significant, as it overturned a 1969 ruling that stated being a staff member at Auschwitz was not enough for you to be convicted. Gröning was known as 'the bookkeeper of Auschwitz', overseeing and helping redistribute the valuables of the Jews. He did express regret and claimed he spoke out in order to contradict Holocaust deniers. This ruling set a precedent for pursuing suspects, many now in their nineties accused of serving in death camps. The federal court's ruling also cleared the way for prosecutions of ex-members of the Nazi mobile death squads known as Einsatzgruppen, which operated in Eastern Europe. Campaigners believed at least eight suspects could now be accused of murder because their membership of the death squads would be sufficient proof. This was a significant change in German policy according to Efraim Zuroff, the head of the Simon Wiesenthal Center in Israel. Programmes concerning Nazi hunters have proved to be just as popular as variety of media forms, such as documentaries, a large number about the life and career of Hitler.

In terms of audience consumption, there is a fragmented approach contributing to a diverse construction of Nazism and neo-Nazism in film and media. Certain products are suggested to a user, depending on what they have engaged with before, platforms such as Netflix developing profiles of whole families. One of the most popular platforms, Netflix has a whole category for films that concern football hooligans, often with neo-Nazi content, other feature films, and documentaries. Films such as Nazi Dawn (Dennis Devine, 2014), where the spirit of a Nazi ancestor possesses a young woman, and Nazi Revenge, where a man has past life regression, following him having nightmares and then believing he was a Nazi, play on the myth that at heart we are all Nazis, and we all have something to atone for. But these are normally horror films drawing on the notion that the Nazi is the ultimate monster, lurking within the uncanny. And such systems do make mistakes. In one instance a documentary on Netflix made in 2011 about Hitler had the description: 'Out and proud, they overcame prejudice to become some of the most influential voices in America's LGBT community.' These words appeared over an image of marching Nazis. Whether this 'mistake' was a real or invented mistake is questionable, given an article was written about it, published on the Internet, and then entered the media domain.

While comedy can be used to tackle the subject of Nazism and neoNazism, this could be considered to be trivializing serious matters. Pushing the boundaries through transgressive humour is balanced by changes in the law concerning Nazi-related crimes. Recent neo-Nazi incidents have been addressed through changes in the law, and this has generated media 
interest. For example, Ursula Haverbeck-Wetzel received ten months for Holocaust denial, after years of just being fined. She had been a Holocaust denier, at one point suing a Jewish organization for discrimination herself, personally taking on the position of a victim. Her flirting with all forms of media across the decades to her downfall, as this provided documentary evidence concerning her illegal propaganda. In a Panorama documentary, broadcast in Germany by ARD television in March 2015, Haverbeck-Wetzel denied the mass destruction of the Jews, claiming it was the biggest and most persistent lie in history. Her level of denial and the publicity she courted indicated she had come herself from a troubled past, although she had infiltrated right-wing political parties, who eventually rejected her. She published a video on YouTube protesting against the trial of Oskar Gröning, and distributed leaflets outside the court, which were reported to feature Holocaust denial. As with David Irving, not only was she trying to rewrite history concerning the Holocaust, but also concerning Germany in general, turning the latter into a victim. In 1992, Haverbeck-Wetzel became the first chairperson of the Memorial Sites Association, remaining in that position until 2003. The association was established to build remembrance for the German civilian victims of World War II, to end what was perceived as an unjustified unilateral view of history.

Just as with the false memory syndrome lobby, there are people active in denying the memories of others. While this might sound like science fiction, it needs to be noted that this is actually the way all of us now exist to a degree. Each news item is filtered through an element of distrust. We get our main news sources electronically, and much of this is entertainment rather than news. Outlets do have fact checkers, but the key point is they often attempt to break the news story as quickly as possible, without actually being at the source. A famous example of this is the German Wings tragedy. No one yet knows the true cause of this, but Russia Today claimed to have broken the news story first, without any of their journalists being at the scene. In this sense journalism and reporting has shifted, morphing into an interesting blend of fantasy writing in parts, given fact checking has become less important. Trump claiming there had been a terrorist attack in Sweden is another example. All he needs to do is promote the same message again and again.

Levinas celebrated difference and attempted to redefine how we viewed the creation of identity, which is a direct reproach to Trump. While Levinas focused on the other, on the refugee or immigrant, for example, Trump denied their existence. The lesson of the Holocaust is one of hope. You cannot destroy a people like this, no matter hard you try, especially a people 
who possess a profound faith. While this may appear overoptimistic, to always focus on the evil on the Holocaust actually lends Nazism even more power. This book has recognized that neo-Nazism proliferates all over the world but it has not gone into the resistance to neo-Nazism, which is strong. Writers of science fiction, such as Margaret Atwood, have revealed future worlds where fascism exists but is embodied in the state and normalized. In an age of austerity, people may not resist and may just become one with main system to survive. We see this in totalitarian states like North Korea, but also in a different form in the UK and America.

British universities are a case in point. The voice of those that might be different are often quashed. The late Jewish MP Gerald Kaufman attacked the fact that pro-Israel organizations within universities in the UK were active in silencing any pro-Palestine voices. This book is a call for openness and a lack of censorship. The question is, Should figures such as Nick Griffin be given such a public platform? With figures such as Nigel Farage this is questionable. The media seemed to believe everything Farage does is newsworthy. The only British UKIP MP up until March 2017 when he left UKIP, Douglas Carswell jokingly claimed that Farage was getting a knighthood due to his contribution to headlines. One thing that needs noting about those flirting with fascism is that they seem unable to take a joke. Trump is the main example here. Comedy can be used politically. Charlie Chaplin claimed that he would have not have made his masterpiece The Great Dictator if he had fully known about the Nazi death camps. This lack of being able to cope with humour suggests fragility unknown to most, and a preciousness that means more mockery will take place. By the end of February 2017, it did appear that Trump's presidency was unravelling, the press beginning to be the opposition.

There will always be people like Trump and Farage who want to grab headlines. Farage claimed that 4,00o people with HIV/AIDS were coming every year from Africa to use the NHS, suggesting that Africans were infecting the pure British. All of this hate rhetoric gets headlines, and some do believe these headlines. But the accountability of these politicians needs to be addressed, not just by other politicians, media scholars, or teachers, but by everyone. To ignore this would be to accept the status quo, and to enable a regressive state of affairs to commence. While this is a fear, it is a sound assessment and one grounded in current affairs. Unless each citizen believes in accountability, we shall find the rights of the citizen eroded. As with Margaret Thatcher, Theresa May has claimed society does not exist. Simultaneously, figures like May and Trump continually promote ideas concerning nationalism and country. 
We began by drawing on the significance of boundaries and postcolonialism, which drew on the wider philosophy of Heidegger. Believing passports should abolished and that boundaries and borders are an absurd human invention is too radical for some to comprehend, but it comes from having a legacy of the Holocaust. Israel strongly defends its borders, and the right for a homeland. For refugees and migrants today having a homeland may sound like a fantasy, and a sense of place is key. We have not yet tackled the true meaning and purpose of neo-Nazism, and to suggest this is singular would be specious. Neo-Nazism in some contexts is part of opportunism, a door to be pushed, or kicked open. In Britain, there is the continual high alert concerning terrorist attacks, which generates a constant fear of the other. After an attack on London in March 2017, the police confirmed that the perpetrator was attacking alone, negating the view that the Western world is under some kind of attack from fundamental Islam. Many people from ethnic backgrounds are killed in police custody, with the work of the Independent Police Complaints Commission stretched. Fear is a way of controlling the population to make the implementation of any policy easier.

To illustrate how extremism has become part of the centre we should consider those who previously seemed from the right now criticizing what they perceived to be too extreme, given its normalization highlights their own complicity. George W. Bush, a former leader of the 'war on terror', has become the voice of reason, claiming he does not like the racism of Trump. In the UK, it is the high echelons of the establishment, the House of Lords, which is attempting to alter Brexit proceedings so the rights of Europeans living in Britain are protected. This reflects on another area, knee jerk culture, the belief doing something is always better than doing nothing. We can identify Trump's policy as being part of this. The philosophy is you need to assert your new order immediately, without any thought and this proof of a deep level of ignorance. You ignore others at your peril. Without a greater depth of consideration, the implementation of anything will be problematic.

Trump's business was sued in the 1970s for discrimination and not employing black people. Time and again he has resisted claims of having sympathies with racists. In the new order what exactly happens is that there is a stalemate. The more Trump pushes for passing policies without consultation the more they will backfire. The greatest leader does not put them self at the centre but situates themselves outside the frame. If we reflect on leadership and the cult of the leader we see that those that desperately need to lead, and require the affirmation of leadership, are often not the best leaders. But fascism, Nazism, and neo-Nazism all revolve 
around the cult of the leader, and the cult of war, and with this is the need for an enemy. Peace becomes anathema, as is recognizing human beings as human beings. The drama of entertainment and media will always find the conflicts generated by these movements of use. Even a non-news story becomes a news story. When a group of neo-Nazis in the UK or Germany hold a rally and more anti-fascists turn up than fascists, this is news.

The feelings of fascism get channelled in differing ways, on to terraces, into boardrooms, and into bedrooms. The culture of fascism has blurred with fetishism, often linked with the sexual nature of Bondage and Discipline (B/D), Dominance and submission (B/s), and Sadism and Masochism (S/M), collectively known as BDSM, as mentioned in Chapter 1. This has become popularized and normalized, but in a clichéd way, as in the Fifty Shades of Grey trilogy by novelist E.L. James. Censorship has worsened. There is no clear line of progress historically, and history itself is just a selection of events, edited by the writer from their own perspective. Evidence needs sifting, and the writer must admit where there have been elements omitted. As reporters say to Trump when he shouts them down as fake news reporters what he really should be saying is that he disagrees with their opinions. The positive side to rolling news media is that people get easily bored. Diverse people, from writer Steven King to George Bush, have criticized Trump's divisive approach, the former calling him a snake oil seller. Globally, many non-Americans can see this clearly, but being caught in the bubble of the American experience this is less obvious.

Ultimately, this comes down to values. Do we need leaders who bring everything back to themselves, who set out a pathway that concerns producing a mirror image of themselves everything, and behind the image is nothing of substance, like the emperor's new clothes, although is that what is desired? If it is, then let us just admit that we do not really need leaders of substance. Even today, Hitler is often portrayed as the innocent victim of those around him, a puppet. Trump is frequently discussed in the same manner. This comes down to our belief in free will. For those who flirted with fascism, like D.H. Lawrence, it is the so-called 'inferior' races that operate on fate, that goes all the way back to the beginning of time. True fascism also draws on this historical emphasis, but highlights the notion of the great will of the people encapsulates in the leader. The leader must be followed always; any dissent is anathema. Even in the Brexit vote we see a reflection of this: the people have spoken, and the will of the people is then used to implement any extreme policy.

Despite fascism often being concerned with the leader, we can see the weight of the group and society. This is a complex, as each area defines each 
group differently. The 'in group' teams up against the outside group. In the UK, immigrants voted to leave the EU to define themselves as part of the group of 'indigenous' people. This phenomenon of defining oneself through difference and similarity continues. Ultimately, we need to consider what has been addressed. The essence of neo-Nazism might be to rewrite or deny history but in Germany the history of the Holocaust is an ever-present mediated reality. Switch on the television most nights and there will be a documentary or discussion on the subject. Publicly it is debated continually, with issues over war memorials (for example; should people be allowed to explore memorials or should they be respected as sacred objects?).

The sacredness of space and place is important, especially when certain places, such as cemeteries, are defaced. This relates to hooliganism discussed in Chapter 1. For example, is there violence endemic in youth culture that concerns the expression of discontent to any other? This is a violence that is omnidirectional, and might involve attacking Jewish graves, Muslim shops and so on. There is no core ideology, and it reflects more on the tenuous nature of youth identity in a period of austerity. We need to be careful when we discuss any act of neo-Nazism as neo-Nazi behaviour because the media may have bracketed an event as such just to make a headline and to bring it to the attention of their readers. This framing of the debate is one way the media lead the creation of neo-Nazi discourse, bracketing together what could be random events under the same banner. With the use of social media, there is a nebulous global network. With hooliganism, even prior to social media, there was a network of right-wing activity. From this perspective, it needs to be emphasized that while the media can create, define and lead the manufacture of neo-Nazism, it exists as an identity.

The strength of the left wing to rebut the right in the UK throughout the 1970 and the 1980 os suggests that the threat of the right wing is a monster that has and can be contained. Whatever people think of Jeremy Corbyn as the leader of the left in Britain in 2016 and 2017, he has a large number of supporters who are vehemently anti-fascist. Marine Le Pen in France may have supporters, but how active these are is debatable. Headlines are floated about politicians dabbling with neo-Nazi politics, from Dutch politicians, to Austrian, and Australian. They have not had definitive success, the populace not prepared to go that far. The popularity of Trump is under question globally, while the referendum success of Erdoğan in Turkey in April 2017 is under question. In Germany, Merkel is primarily a conservative, but she has had the ability to be flexible and shift her position over major issues, such as energy. Eric Hobsbawm famously called the current age the age of insanity, and he may be right. ${ }^{20}$ Merkel is the alternative voice of reason. 
David Cameron gambled and lost everything, and it was Cameron who claimed that Merkel's welcoming attitude to immigrants would mean she would be gone in six months. Despite a variety of incidents, the right-wing hysteria that followed Brexit has not fully taken hold.

In a theatrical sense, Nigel Farage and Donald Trump are comedy figures, a sideshow in the Punch and Judy game. The UK's Foreign Secretary Boris Johnson also fits this paradigm. Despite being attacked by the mainstream press, which is dominated by right-wing ownership, Corbyn had always been known as a moderate while being a backbencher. Unless you engage the press in an entertaining way you will be condemned forever, like Corbyn. In February 2017 Labour lost a seat in Cumbria they had held for 83 years to a political novice. Corbyn, unlike any other British politician previously, would not claim any responsibility for this. In this respect, he can be compared to Trump. The UK was moving towards a one-party state; with no opposition, any policy could get passed, and rights removed. Whether this was fascist or not, it is unhealthy. Without difference there is no accountability, but prefer this to a state that has numerous parties at war, with nothing achieved. The wave of right-wing successes witnessed around the world is not comprehensive. In Austria this was not a total victory for the right. People were now realizing they need to take control.

There is a context beyond party political politics. In small and large organizations the question is, Why do we need leadership at all? The suggestion is that people need orders to be organized, that the human is ultimately not to be trusted. In 2016 Spain appeared to function well without a government for over a year until the left compromised. This needs recognizing. We need to offer a way forward where people feel empowered. Venerating strong leaders does not offer empowerment. The deification of the leader is one element of neo-Nazism. For the media and headline writing this is how the discourse is framed. Farage was given an inordinate amount of airtime, as is Trump. But do people really support these figures, or are they more kicking against a system? In this sense, anything is better if you feel you have nothing. The support for the right should not be misread as popular support, although the emphasis of the media means this mistake is made. Similarly, even if millions of people have viewed or liked a certain neo-Nazi event on social media, it does not mean there is real support. The tangential and often tenuous nature of support needs highlighting. Voter turnout is often poor. This suggests that the population believe there is little chance things will be changed.

As with football 'firms' of the 1980s, right-wing support is not linked to class. Football supporters, who may have had racist sympathies, often 
came from wealthy backgrounds. The tribe of football offered an identity where transgressive activity could take place, such as violence. The manner in which Nazi and neo-Nazi groups have been constructed in and by the media has offered them an enormous amount of power that is beyond their real significance. Farage claimed that he had achieved his aim of Brexit, 'without one shot being fired'. He forgot the killing of Jo Cox, murdered by a man who was considered to be a neo-Nazi sympathizer. But violence can be non-physical. Every day immigrants and refugees live under the threat of all forms of violence and terror. This terrorism is far wider and endemic than any threat from fundamentalism. War at any level from Trotsky on the left, to Mussolini on the right, is viewed as the locomotive of history, and there is fatalism. What is necessary is to challenge any form of fatalism. The left believe the right will die away, and the right that they have divine right to rule. Both of these positions are false. The media has added to this sense of fatalism.

The role of the media here is significant. Instead of changing the world, citizens are more likely to photograph and record it, or watch other broadcasts. This may work to change reality, but it might also just mean a false sense of activity that is narcissistic. The way the media colluded with the FBI over Hillary Clinton's emails is of note. Pollsters claim that this attention was the final reason Trump gained victory over Clinton. Clinton had broken protocol and used her personal email account for communications. During the campaign Trump said he would work to put her in jail for this. On this, he relented.Julian Assange was part of this campaign against Clinton, releasing batches of emails. Globally, the media reported on this event instantaneously, as you would expect. With the FBI commenting on this event right up to the election this can be said to be a major influence. The security forces, with underground media movements, along with mainstream movements, enabled the victory of a president who was backed by many white separatists and some neo-Nazis.

This is where the media's responsibility comes into play, operating in a 24/7 climate, where breaking the story is more important than anything else. A surface-level approach to understanding distorts meaning. If this is going to be the only source of information informing opinion, including positions on how to vote, then this is dangerous. With more guerrilla journalism and freelance journalism and independent media outlets, it is hoped that there will be a shift and change in emphasis. Local stories and more different stories might be picked up, with greater depth. However much Nazism and neo-Nazism is rebranded, the worship of the Volk appears atavistic, a stepping back to a period that never existed. Brexit was part of 
this, and led people to question what exactly is English or British culture; Morris dancing, fish and chips; is that it? The archetypal British writer Iris Murdoch mocks this framework and as early as the 1950s saw this as a fantasy, but one that tempted rational beings. ${ }^{21}$ The media has fuelled this fantasy. In psychoanalytic terms, these are aimed at removing anxieties but create more anxiety by removing the thought required to tackle the anxiety. ${ }^{22}$

Tied into developments concerning a backlash over Trump and right-wing politics is the issue of freedom of speech. In Holland in March 2017 there was an active campaign to promote the rights of those who want to speak right-wing views. The ethical and moral question concerns whether people should have the right to state that others do not have rights, and how far should a society promote this right? Should liberal values be used to promote illiberal values? This is not to say that allowing people like Nick Griffin to speak in various settings is wrong. It is felt that giving people this permission lends their views some veracity. Within capitalist systems conflict, not just physically through war but through debate, is felt to be the way to gain a good result for everyone concerned. The reasoning is if we allow such beliefs to be aired they then can be challenged. What is concerning is the manner in which groups, such as white supremacists or extreme right-wing groups, then claim that they are the victim. Holocaust deniers have constructed themselves as victims. Donald Trump and his administration have claimed they are victimized, with any investigation by the media into him or his administration condemned as a witch hunt. The media continually shifts the power balance towards those who sympathize with such beliefs. This is not to suggest the media overtly backs such beliefs, given these beliefs are often overblown by the media. This is part of a strategy not merely to create headlines. Creating a culture of fear means people may pay more attention to the media, as they believe they need to know information about important events to formulate their opinions and behaviour, quickly.

Writers have explored this culture of fear. ${ }^{23}$ Waves of panic are constructed, some stemming from valid stories concerning incidents, such as child abuse. In this context, it is unlikely that many people will encounter neo-Nazi violence. Racism is part of a wider problem. The specific elements of neo-Nazism are not as popular as media reporting accounts for. Bracketing events and people within this framework is a way of formulating a type of story which fits a certain brand of news. Contexts and specifics are often overlooked. Those engaging with the media are left to deduce the veracity of these stories and whether they are linked to neo-Nazism or a form of construction. The more extreme right-wing politics becomes mainstream 
the more its power dissolves. The political right obviously still exists, its voice is strong, but it has absorbed and watered down some of the extreme right; the left and centre are still resisting the extreme right's demands.

Trump's administration, swamped in scandal by March 2017, may turn out to be even more ineffectual than Obama's, after all the bombastic rhetoric concerning getting things done. As a distraction, in April 2017 Trump decided to create a high level of tension with North Korea and China which continued into August with threats of a North Korean war. Celebrity culture, with the focus on the individual, has allowed a form of phony politics, where someone is seen as a good leader just because they are well known. The weakness of Nazism and neo-Nazism is, amongst other things, an overreliance on the 'truth' of the leader, however fake it may be. The desperate attempts to have a strong leader, who is always right, means there will always be gaps, in that it is very nature of humans to have flaws. Paradoxically, the strength of the human is in the gaps, given creativity comes in the gaps. This is not the case for the perfect Nazi 'overman' who is not merely human.

Why people think they need to be led is an interesting question, as if they have been nurtured from birth to view the opinions of the central leader as superior. This level of subjugation, or a chosen desire for it, in the twenty-first century appears anomalous. In times of global insecurity these needs may become more paramount, hence the desire. Those who want to foster this allegiance are creating this form of insecurity. There is then dependency and conformity, people not challenging the social order. All dictators begin by claiming they are giving power back to the people. This is a process of propaganda that is overt. There is a condemnation of one establishment by the outsider, such as Trump, and then the enforcement of their system of power. In this sense it is voting for someone who claims they will shake everything up. This form of shock therapy is supposed to jolt the system, the social order, and the economic system. It can be perceived to be a form of punishment, aggression and regression. To define progress is a difficult task, and it seems the neo-Nazi system wants to delete history, bypassing globalization and multiculturalism. How this can be achieved is difficult to tell, other than by creating a whole new version of reality based on fantasy, which is what The Turner Diaries does.

Richard Spencer's alt-right did not come about through lack of education. There is form of attractiveness, a sense of power and an assurance, that can appeal to a certain personality that is too weak to allow the 'other' to challenge its beliefs. This exists in organizations, cultures, societies and countries, where any form of mistake or unethical edict can go unchecked. 
In Nazism there was often guesswork by those following Hitler. A question arose over whether there was a sanctioning or not. Predicting approval is one way of functioning without free will; it is a form of slavery, but it offers a level of freedom through removing free will. The need for a tribe is important for identity formation. Often media discourse is formed through accentuating the differences between tribes. Conflict creates drama, and this creates a story. In this regard, the threat of being an outsider is so great people will do anything to be absorbed into the tribe.

Surveillance culture is an important component, given Nazism and neoNazism can only thrive via surveillance, where people feel threatened and under observation. Identity is removed in the herd. There is the notion of becoming one with the masses, but this can lead to an absorption into transcendence, the link between Nazi and neo-Nazi belief systems and quasi-religious experiences strong. With so many 'lone wolves', such as Dylan Roof and John Mair who claim to have acted individually, the wider network of neo-Nazism fed their sense of identity even if it was imagined. They were metaphysically at one with the pack through their allegiance, despite being physically alone. The British media framed the killing of Jo Cox as the killing by a mad man. John Humphrys on Radio 4's Today programme refused to permit John Mair to be called a terrorist, saying it was murder by someone mentally ill. Cox had praised immigration in her maiden speech in parliament, making references to Irish Catholics and Muslims from Gujarat in India or from Pakistan, principally Kashmir. In her speech she had emphasized what united people. Mair apparently shouted 'This is for Britain!' before attacking. During his trial it became clear he was a white separatist.

With other white terrorists, it is harder to say. Timothy McVeigh's case is more complex. The authorities wanted McVeigh to take responsibility for the Oklahoma bombing, but he could not have acted alone. While this act of terrorism may have inspired other acts of terrorism it is difficult to just brand this neo-Nazism. Belief systems have variances within them, and can change rapidly, depending on external events. The media can brand and rebrand any of these events as neo-Nazi related, creating an aura around them. This lends them a certain power, often in a paranormal sense, given the mystique initiated through the repeated reporting, lending them deeper significance. The weight the media gives to events indicates it operates as a multiplier, not merely to the signifier, but to the signified, manufacturing meaning beyond meaning. Andy Warhol elevated reduplication of the image to an art form, offering a religious significance. The process works in a similar fashion here. 
Whether we wish to frame right-wing attacks as terrorism or not, we need to be careful branding these killers mentally ill. Doing so excuses them of any culpability, and if we look at how methodically many of these incidents are carried out it would be wrong to claim this is all linked to mental illness. Definitions of mental illness alter from place to place and time to time, so we also need to be aware of the cultural construction of the sanity/insanity binary. The same could go for terrorism. With Islamic terrorist groups the term 'brainwashed' is used, so people are not exactly mentally ill, but are being used as tools of a certain ideology. The question in all these incidents concerns culpability and choice. This is about identity formation, of giving up the self to a wider cause. While narrowing a person's outlook, this offers a greater sense of identity.

Any causal relationship between the media's framing of these debates and the actions of individuals is only conjecture but it is clear that indirect elements can be extrapolated. For example, in the case of the killer of Jo Cox, seeing John Mair's case framed as that of just a lonely man having had a psychotic episode, the public will be unlikely to attach any strong belief system to the perpetrator. Repeated often enough, there is no way this will then be interpreted as a form of white separatist terrorism. The cause of the attack is positioned as the act of a mentally disturbed state of mind, brought about via isolation not linked to ideology. Mair then becomes a victim and a man society should have reached out to, vulnerable and in need of help, rather than a dedicated murderer with a sense of purpose and ideology gained from years of following a form of neo-Nazism with international contacts. This is often how such attacks are often framed, especially mass shootings in America.

As these attacks are framed as moments of madness, despite evidence that individuals may have been rationally planning them, political motivations are diluted and become non-existent. The cliché of a mad man opening fire in a shopping mall, a school, or a cinema, is framed as a random event, not linked to gun control, belief systems, ideology, or the system that legitimizes violence. Randomness and chaos become key to this media framing, which is a significant paradox given formulating a narrative around these events is key to news reporting. Nothing is learnt from these attacks, as they are constructed as existing virtually outside time and space in a non-rational zone. They are promoted as part of the unconscious death wish of society just being acted out. In reality, or in fiction, such as the work of J.G. Ballard, these acts of violence become part of the normality of daily life. As with Nazi and neo-Nazi discourse, what is by nature extreme enters the mainstream. 
We can directly contrast the way these killings are reported with the way killings by Muslim groups are reported, where they are immediately linked back to the apparent training zones of ISIS, which are supposed to be undermining Western democracy. It is not capitalism that is undermining society, but ISIS. The latter is then positioned as part of a war, but then this war and the events surrounding it are normalized as part of the random nature of day-to-day life. The complexity of this is that the war itself has now become normalized. This is nothing new. Prior to World War II, British newspapers were full of accounts of disastrous campaigns by the British army in Afghanistan, an eternal war. Despite Donald Trump claiming throughout February 2017 that acts of terrorism were going underreported in Europe, for what he stated were political purposes, one could argue the opposite is the truth. Capitalism thrives on fear, and as we enter a postcapitalism era given there is a greater awareness of the limits of capitalism, this further thrives frenetically on stories concerning terrorism and disaster. This legitimizes sanctions and crackdowns, and military sales, gaining government support from the groups they need to support their power base.

This media discourse is not journalism but state-sponsored propaganda. To paraphrase George Orwell again, journalism is printing what someone else does not want printed; everything else is public relations. We should realize by now that the mainstream media is ultimately concerned with protecting the establishment, and the interests of its major shareholders, and this war on terror legitimizes everything and anything. In stories concerning attacks made by right-wing terrorists there is a loss of the signified in the construction of the story. Unlike Islamic terrorism, it is not repeated as part of a pattern connected to a geographical heartland, or territory. It is not constructed as part of a war. This is despite the militarization of the right, covertly and overtly, even in their obvious appearance, with skinheads and army boots and jackets, and names, such as Combat 18.

While the various right-wing groups attempt to project an image of themselves as organized units, with various divisions, as did the Nazis, the media is too busy in rehashing stories concerning Islamic terrorism to really take notice. For Martin Bell, Al Jazeera UK is the most legitimate news organization, offering the most objective news. Media outlets like Russia Today are entertaining, if we acknowledge they are often propaganda outlets that give one side to the story. And it would be farfetched to assume every side to every story could be given. Importantly, during a period when in Britain Enoch Powell was making his 'rivers of blood' speech in Birmingham, claiming the UK was being over taken by immigration, there was actually net emigration. In his Radio 4 series 'Neither There Not Here', broadcast 
in March 2017, David Dabydeen revealed how for many the way they were treated in England when they first arrived from different countries was actually better than the situation today. We could be sceptical and suggest people are looking at the past through the eyes of nostalgia, but when we consider that at this period there was a certain level of objectivity towards strangers, this is significant. With the global media focusing continually on ISIS, and the threat of terrorism, and the British police saying an attack is imminent, the incidences of racist attacks against groups, especially Muslims, is predictable. Manufacturing such attacks then detracts from real inequality, and the establishment can continue to move wealth into the hands of the few. This is of real concern in Trump's America.

The police promote the idea that acts of terrorism by Islamic fundamentalists are inevitable, and in this sense unpreventable. Acts of right-wing neo-Nazi terrorism are seldom framed as terrorist acts, and are bracketed as isolated incidents, beyond rationality. This latter device then places these acts as beyond comprehension for any real consideration. Neo-Nazi acts of violence are framed as manifestations of nationalism, after certain groups claim they have become the marginalized voiced and the victim, following mass immigration. This legitimizes certain forms of violence. In Britain, there are numerous inquiries being conducted by the IPCC into racist violence carried out by the police, including many deaths in custody. The UK police was termed institutionally racist. Given the extent and number of the IPCC investigations it seems unlikely that the correct level of resources will be offered to these inquiries. Inevitably, cases will be overlooked and not investigated thoroughly.

The desire to construct an identity around an affiliated tribe can be so strong any level of violence will be utilized to prove membership. This we have seen portrayed in films offering a moral outcome where a shift occurs towards a hopeful ending, suggesting change is possible. Sometimes films do not offer such an ending, as with the popular American History X; despite the older white brother reforming in prison, the younger brother shoots a black student. The senselessness of this is emphasized, as is the inevitability. The resistance of groups like the Anti-Nazis League in the UK is well known, and there is a global fight against fascism. Despite the victory of figures like Donald Trump, backed by white separatists, there is a global movement to resist the rise of fascism. This is linked to areas of resistance, but the incidences of neo-Nazi attacks have risen.

While there has been a drift in politics, making neo-Nazism part of the mainstream, the law has actually changed to counter hate crime. For example, the Cult Education Institute (CEI) reported on their website that 
on 22 November 2014 a neo-Nazi received seventeen years for email threats. The magazine Rolling Stone on 23 June 2014 had the headline 'Heil Hipster', for an article concerning Germany's only neo-Nazi Internet TV show, but this was satirically mocked. In Britain, there were various cases reported by CEI, including a neo-Nazi plot to kill a Spanish judge. In Europe, the CEI reported a rise in neo-Nazi attacks of 16 per cent, the period unspecified, in countries such as France, Germany, Denmark, Poland, Italy, Belgium, Hungary and more widely in Russia. But has anti-Semitism ever gone away, given anti-Semitism is not linked to a time and place, such as Germany in the 1930 s and 1940s. Michael Laitman asks, 'Can there now be Nazism in America?'24 There have been 70 recent incidents of bomb threats aimed at Jewish community centres in America, two graveyards have been attacked (one in St Louis, and one in Philadelphia), plus numerous other incidents. ${ }^{25}$ As a society becomes more selfish and divided it becomes more anti-Semitic.

For some this hatred is a form of pleasure, and is an innate part of the human condition, as Slavoj Žižek has claimed throughout his work. With reference to Rattansi, this view has been questioned in this book. It is in many ways egoism, not just today but throughout history that has allowed this hatred to advance. As history moves forward the level of altruism does not necessarily move forward. Laitman makes a good comparison with the Spanish empire. When the Spanish monarchy was at its height in the fifteenth century it moved in for the kill. There was a sanctioning of the Inquisition under Torquemada, who was of Jewish descent, in an attempt to destroy Judaism. Laitman points out that saying the Nazis were a one-time event is inaccurate. For example, it was not the Germans who invented the badge Jews wore, but the British in 1218. In this view, it was because other countries did not take the Jews that Hitler exterminated them, but this was not an intrinsic part of his essential policy. This is still a contested point, given the eradication of all Jews is considered the essence of Nazism. ${ }^{26}$

George Orwell ends his book 1984 with an image of fascism, blending with the sci-fi mechanized dystopia: the future is a boot, stamping on a face forever. Following Levinas, while there are still people alive to recognize the value in each face, and the importance of difference, this boot can be resisted. Regardless of how the media construct, collude, or resist Nazism and neo-Nazism, it is important to stress engaging is the key. In the Western world in particular, where many have forgotten the fight that went on to win democracy, politics is often frowned upon and frequently ignored. By ignoring politics, extreme right-wing politicians can do their work more easily, claiming they are one of the people. Donald Trump may claim the media is full of fake news and lies, and the establishment is out to get him, 
but as of January 2018 it is hard to believe he has any credibility. Looked at optimistically and philosophically this does not need exposing, because their behaviour is doing such a good job on its own of bringing about their own downfall. This is an overly optimistic conclusion.

When these belief systems become blurred within the mainstream, exposing, condemning and challenging them because extremely difficult. The suggestion has been made that people benefit from these neo-Nazi beliefs, so why would they challenge them? We have reached a point in history where objectivity is not especially valued, and even the media images people live by are not valued. Those in charge of the main economies of the world have the loudest voice, with the media often being nothing more than public relations. Despite the power of Twitter and Facebook, well thought out and argued journalism is key to resistance. To argue against voices of power, through the media or otherwise, is an important way in which the spectres of Nazism and neo-Nazism are kept at bay. Keeping them at bay will not mean pockets of Nazism and neo-Nazism will not resurface, but it will mean that these voices are not normalized, or accepted totally. No matter how much media spin Britain First has done via Facebook, it is still an ostracized group, on the fringes. This does not mean the arguments of this book are invalid. What we have traced is a trajectory of acceptance. What now is proposed is an attempt to challenge this acceptance.

We do not have to believe in the central destructive power of human nature to accept this urge to attack the other needs challenging. Exposing all levels of inequality is central to combatting Nazism and neo-Nazism, which functions as a quick fix solution: get rid of that group and you will be fine. There might not be as yet any true definition of what it is to be human, but it is easy to acknowledge what it means to be humane. Nazism and neo-Nazi thrive on the degradation of the other, on dehumanizing the other. Paradoxically, an attack on the other does not boost the self, but the opposite. Any magical panacea to the problems of society needs questioning. Figures such as D.H. Lawrence believed that a form of blood lust was within the other, specifically in non-Western races. This could then be used to declare the other needed wiping out. We see this myth perpetually reworked in fantasy genres, such as the vampire story, which frequently bring in a subtext related to the Nazis. There is a deep need to deal with the shadow part of human nature, as analytical psychology describes it. If it is not acknowledged it comes out in many ways, which may not be controlled.

For Pythagoras and numerous thinkers after him no one is free if they cannot command themselves. The savagery of neo-Nazi belief and the violence that can be manifested from this beliefleads to the conclusion that 
some wish to give up their freedom. It may appear easier in the short term to relinquish one's freedom, to go beyond existential doubt. A certain form of clarity comes with following the pack, believing in the herd mentally, and avoiding the pain of existence. But this is becoming a beast. By doing so, there is then the infliction of pain on others. The trouble with this either or binary scenario is that it removes all levels of freedom, until both sides are trapped. People are then positioned in cages of their own making. Those living in Nazi Germany had to conform, otherwise they too were the enemy, and paranoia was rampant. We see this in contemporary political movements, right and left, which focus on fighting to get the group to adhere to fixed tenants. The question is: Do people want to be free and, if so, what are the costs of this freedom? Enslavement and the degradation of the other?

In the film I.D. (Philip Davis, 1995) where an undercover police officer played by Reece Dinsdale joins a racist football gang, the police force can be conceived to be just as racist. A harder and more contentious question we have to ask is: Does he have a choice here? To move away from the animal to the human may be criticized as speciesism, but cooperation, which is inclusivity, is surely one of the important elements of a high functioning human. Nazism and neo-Nazism from this perspective is low functioning, based on a level of tribalism that denies this grander concept of the human. This may seem obvious, but there is a branch of politics that declares greed is good, that selfishness, at all costs, is good. Once this is accepted, anything is acceptable, and all manner of atrocities conducted, and then ignored.

The media can speak out against these atrocities, which may cause them to be stopped, but combating these atrocities needs more than the media on side. Paradoxically, it needs our mainstream politicians and their supporters to realize they are often thriving from inequality. Their silence is complicit with the wider crimes discussed here. This level of complicity is deep and part of a silence concerning austerity and cuts to welfare globally. To resist the status quo, and to be outside the herd is difficult, given the weight in the West to proving one's value through competition, acquisition and consumption. There is, however, a level of self-chosen ignorance. All that is recognized is the self that is warped by an immersion in all forms of media. In such a climate everyone is still culpable, and a choice is still to be had.

\section{Europe's New Far Right and Conclusions}

In 2017, a country known for its liberal and progressive politics was at the heart of the immigration debate, with the Dutch party of Geert Wilders 
having enormous influence. Despite Brexit and Trump's victory, no one was predicting Wilders' victory, but in many ways he had already won. Mark Rutte, Prime Minister of Holland, had a letter printed in every main newspaper saying people must accept Dutch values. Much of the rhetoric in Holland was even stronger than in America. There was the basic view held by Wilders' supporters that the criminal element in Holland was made up of foreigners, and if you removed foreigners you would remove crime. Wilders used nostalgia to appeal to voters, a tactic employed by other parties such as UKIP. He had already been found guilty of inciting to racial hatred by calling one group scum but continued being contentious which made him a gift for the media.

The parallels between the UK and Holland are obvious. In both cases, mainstream parties felt they had to shift to the right, and use right-wing rhetoric. The fact that the neo-Nazi agenda was now dictating policy should be concerning. The dream of a multicultural Holland seemed to be disappearing. Even though this is just one example, it is a good case study for a global trend, given the once accepting nature of Holland within popular mythology at least. While supporters of a right-wing agenda were airing their views, the media also produced programmes constantly reminding people of Jewish history. In Germany there is a constant reminder of the history of the extermination of the Jews, but support for neo-Nazi groups still remain. In times of austerity this is bound to be the case. What is phenomenal is how the general public is often in full unquestioning agreement with the policies of government.

In the UK, for example, with the Chancellor of the Exchequer Phil Hammond in charge, there were tax breaks in 2016 and 2017, but austerity was emphasized. There was an increase in racist and neo-Nazi violence in the UK post-Brexit, and an increase in those below the poverty line. Blaming this on immigrants was a simple solution, and this was a policy Donald Trump wholeheartedly approved, diverting attention from his own activities. Trump began implementing policies concerning who had entry into America. This was not part of any extreme white separatist movement, but was constructed as a purely rational move. In its second format, after the initial edict banning people failed, by March 2017 this was supported by mainstream Republicans. Trump appeared to have success, even if this was all about media manipulation. The fact that the president of the United States would spend so much time in point-scoring activities with celebrities and media outlets indicated he had the wrong priorities. What was not so clear was where his policies were stemming from exactly. 
Bannon had already gained a following through his media outlets. Taking a backseat to Trump, but still leading on policies and manipulating messages, gave him even greater power. When he stepped down in August 2017, he claimed he was going to war for Trump and would have more influence outside the White House. Trump was able to circumvent all criticism by just carrying on regardless, but appeared to be doing more to win the support of his own military. To never admit your mistake was part of his mantra, initially, with the blame always being placed elsewhere, such as: on Obama, the media, the judiciary, China, Mexico, Germany, France, climate change scientists, everyone and anyone else. This tactic was so unlike anything anyone had ever seen before it was genuinely working, although in August 2017 he admitted his policy on Afghanistan had been wrong, and America was not withdrawing. In Holland, Prime Minister Mark Rutte of the centrist People's Party for Freedom and Democracy (VVD) absorbed some of the anti-Islam beliefs of the Dutch Party for Freedom (PVV), led by Geert Wilders. Similarly, in the UK Jeremy Corbyn did not explicitly ever claim to be pro-Remain. Despite being praised as a politician with true values, Corbyn was shifting within the political landscape, and most insiders saw him as anti-Europe.

Despite the rising strength of his party, political analysts believed it would be difficult for Wilders to seize power, as no one from the 25 other parties standing would work for him. This was unlike during the period of Hitler's rise to power. At least in Holland this showed a clear level of support for the anti-Islam agenda. What complicated things in Holland further was the strength of the left. Previously, a right-wing politician had been shot dead, and Wilders was given top-level security protection. The strength of feeling was tangible in Holland. Channel 4 News in the UK reported on 7 March 2017 that there was a battle in Holland between those Dutch people who felt threatened by immigrants, and the immigrants themselves who felt threatened by the racist local people. Whatever the reality of the situation, Channel 4 was attempting to offer a window into the Dutch elections happening the following week, as a subtle warning on Europe as a whole. The truth was that the position in Holland had shifted. All politicians had to take the position of the right seriously. Unlike in America, they were not forced to work with them.

Writing in The Daily Express in March 2017, Alice Foster asked whether Geert Wilders could cause Europe's next right-wing political earthquake, predicting he was leading in the polls and might win. ${ }^{27}$ The media has a vested interest from a number of perspectives for writing such headlines, and even for implying there is a certain inevitability to this. The Daily 
Express had not been fully reporting the Wilders trial, ignoring the fact that Wilders had stated Moroccans were 'scum', something covered by Channel 4 News on the 7 March 2017. Like Trump, Wilders claimed the judges hated his party. Wilders wants to ban the Koran, the burqa, and Muslim immigration in general, calling the Koran 'the Mein Kampf of today'. Like Trump calling Mexicans rapists when Americans were using Mexico for its cheap sex, Morocco was a zone for sexual exploitation by northern Europeans and the West in general. The level of hypocrisy was extreme, Wilders' followers reversing this reality.

As with Trump, and Farage, Wilders is anti-Europe, and believes holding a referendum on membership in the European Union is key. An anti-international stance is a policy all right-wing parties and neo-Nazism shares. Wilders produced a film in 2008, Fitna, splicing passages of the Koran with images of terrorist attacks, and was banned from entering the UK. Since then this ban has been lifted, as he was found not guilty of inciting hatred towards Muslims with this film. The constant message that certain Muslims are being trained in camps, radicalized, and then returning to the West, is promoted without question. Wilders spent two years in Israel. While it is not being suggested this experience was part of his own radicalization to become so anti-Islam, his own history needs addressing.

The UK police in March 2017 claimed over the previous four years they had thwarted thirteen serious terrorist attacks, and at any one time five potential terrorist threats were being dealt with. No details of course were given. The radicalization of right-wing figures, like Bannon, Farage, Trump, Wilders, and Le Pen, needs addressing, but it is beyond the scope of this book. What is of interest is the way these right-wing figures are constructed, as opposed to Muslim radicals. The war in Iraq cost approximately half a million lives. No terrorist act by a Muslim group has caused such extensive loss of life. Such comparisons may not appear on the surface to be in any way reasonable, due to the complexities of each situation. But as the work of Adam Curtis, such as his 2015 documentary Bitter Lake, indicates, governments and the media have simplified the issues, especially with Islamic terrorism which in its current form stemmed from agreements in the 1970s. This early agreement between America and Saudi Arabia allowed for resultant forms of terrorism, such as Al-Qaeda and IS. It would be wrong to claim that Western foreign policy was not the primary cause of Islamic terrorism. Nazism and neo-Nazism may be anti-government, anti-international, and anti-Jew and Muslim, but it fails to engage with any historical detail, such as this. Certain tales are taken as the truth, and with a limited view of history and politics, the narrative of the past is rewritten. Wilders calls 
Moroccans 'scum', Hitler called Jews 'vermin'. Wilders shouts loudly, and those who feel anger tap into his style, seeing it as offering a voice to the people of Holland, against the 'infidel'.

In America, the alt-right movement has tapped into support from the wealthy. This has resonances with the British football firms of the 1980 . These groups, such as the Chelsea Head Hunters, dabbled in racist violence, but were often made up of high earners, people from rich backgrounds using this as a form of release. American films, such as Fight Club (David Fincher, 1999) have covered the theme of the American man oppressed by the system attempting to break free. Ed Norton is the star of both Fight Club and American History $X$, previously mentioned, which directly tackles this subject of neo-Nazism, both films revealing how violence can dominate our lives. The former does so, in part, through offering a comic approach to violence. With the History Channel and any number of documentaries covering the topic today, watching the moments in German when they turned on the Jews, we can see echoes today of this moment. There is a certain obvious glee from the local population that is revealed by these documentaries, when we view the Germans destroying Jewish property in the 1930s. People can be seen taking pleasure in this destruction just as today in Holland people condemn Moroccans with a high-spirited virulence.

Riot police clashed with demonstrates in Holland in March 2017, as the Netherlands barred Turkish ministers. This was due to the ministers using the visits as campaigning tools for President Recep Tayyip Erdoğan. Ironically, he then branded his fellow NATO member a 'Nazi', after his own government had been cracking down on all dissent, rounding up and imprisoning tens of thousands of academics and journalists who did not support his regime. The Dutch government needed to look tough, to prevent even more support going to Geert Wilders' party. The demonstrator wanted to meet family minister Fatma Betul Sayan Kaya at the consulate in Rotterdam, but she was escorted back to Germany, while demonstrators were beaten with batons and the police used armoured vans, dogs and water cannon, while some were on horseback. The vote in Turkey concerned turning a parliamentary democracy into a presidential system, plus increase the number of election cycles the president can stand in, meaning Erdoğan could be in power until 2029. He is seeking support across Europe from Turkish émigrés. Elsewhere in Europe tension was high, leading up to the referendum in Turkey in April 2017, with four rallies cancelled in Austria, and one cancelled in Switzerland, with the German chancellor Angela Merkel taking a strong line, saying she would not let the tensions spill over into Germany. Turkey is a prime example of how a country had 
moved towards democracy but one leader was now trying to seize supreme authority, claiming this would make the country safer. As with Trump and Putin, the threat of terrorism was being used as a smokescreen to hold on to power. Any change like this in Turkey would be possibly the most significant change since 1923, when the Turkish Republic began.

Turkey then threatened Holland with sanctions, with Wilders in a tweet on 11 March calling on the Turkish people who supported Erdoğan to leave Holland and never come back. Interestingly, this threat from right-wing Turks actually bought all Dutch parties together. With Turkey making these threats in the run up to the Dutch elections they were seeking to threaten the democracy of another country. Holland in March 2017, comparatively speaking, was doing well economically, and resurging from the global economic crisis; unemployment was at a five-year low, and economic growth standing at 2.3 per cent. The main emphasis in the election was immigration and integration. Outside the major towns and cities in Holland there is a certain worship of the past, where immigration is not part of an acceptable form of society. In this respect, it is understandable how Wilders has a broad-based audience, and a strong level of support. Like Trump, Wilders has cultivated a larger-than-life persona, and courting controversy through outrageous statements has been central to his success. The nostalgia that is sweeping the world is linked to this rise of the right, and has come at a moment when the impact of the progressive politics of the 1960 s may have been felt the strongest.

Wilders uses windmills frequently in his propaganda, and anything that speaks of traditional values in Holland. Nigel Farage in the UK cultivates the image of a traditionalist, through his carefully manufactured projected behaviour, and even his dress sense. He creates an image of a man who enjoys nothing more than a pint of bitter, in his traditional English pub, but any further culture promoted by the UK that has his approval is difficult to ascertain. There is the false idea that in the past things were simpler, and values were clear, and foreigners have just corrupted the natives. As with Steve Bannon, the progressive politics of the 1960 s are condemned outright as encouraging immigration, which has threatened the foundations of society, and this myth is continually repeated until many have believed it. Interestingly, in America while Charles Manson was constructed as the fall of the 196os, a living embodiment of all that was wrong with the counterculture, Manson was actually a white supremacist. In his cult, he condemned any relationships between white women and black men, and predicted an apocalypse in society caused by such miscegenation. In this regard activities by the Manson family should be branded as terrorism. The 
training ground of the family was American soil. Homegrown terrorism like this might be branded as satanic, cultish, racist, or merely an extreme version of the patriarchal system gone wrong, but it is still terrorism. Discourse over apocalypse appears to prevail in each era. Writers such as Norman Cohn have examined such a phenomenon, and it is relevant for neo-Nazism and white supremacy. On the one hand, there is the fear of the end of the world that is being caused by miscegenation, and on the other there is a celebration of this as it leads to an attempt to bring about what is perceived to be a purer world.

The influential text The Turner Diaries has been explored as being significant in many forms of media, from the television series NSU German History $X$, to documentaries covering white separatist movements, such as those involving Cobb. All racist movements, from the BNP to the Nazis, have re-interpreted history in a way that constructs the past through a certain narrow lens. Representing the BNP on Question Time, Nick Griffin completely rewrote history, emphasizing a mythical purity of the AngloSaxon 'race'. Drawing on aspects of Hegelian philosophy, which believes in the spirit of history transcending the human, racist groups concur with the view that there is essentially a predetermined element to racial purity. This view holds destiny and fate to be central to the belief system. In this manner, there is no choice in 'real' behaviour, because destiny will prevail. The weak deserve to be eliminated because they are weak. Even a cursory reflection on this can lead us to see how this view is often part of mainstream discourse. Going all the way back to Abrahamic law, there is the central notion in the West that those who work hard will achieve and prosper, and those who are not prospering are not working hard. In the latter's case, their lack of success is often portrayed as a sign of weakness.

The tabloid press frequently constructed those on welfare and benefits as actually parasites, lesser beings, relying on the overgenerous system. In this sense, some of the core values that can be seen at the heart of Nazism and neo-Nazism are also at the heart of mainstream societies. The fact that this is the case should be cause for concern. People are taught from birth ideologies that connect to these beliefs, so they eventually are not even considered to be beliefs but part of who we are. There is no real agreement on what it means to be human, but it is appropriate to use the term 'humane'. In this regard being human is not a state of being, but an ongoing process. We are not truly human unless we behave in a humane way, but who decides this? Any behaviour that denigrates the other in any form lowers humanity, bringing us closer to animals, who frequently do not have a choice in the way they behave. We possess language and are possessed by language. 
Geert Wilders may use derogatory language to describe Moroccans, but this actually reflects on his own humanity. It means he has a lower level of humanity himself. To go with the herd, and seek aggrandizement through group hate, appears to be a position people today in Austria, Holland, the UK, America, and many other countries are in. This self-dehumanization through dehumanizing others, often done unconsciously, reveals people are not fully realizing their potentials as human beings. The fascination that the media has with this whole area of dehumanization, in all its forms, has been the subject of this book. None of this will change unless humans can actively promote knowledge of the concept that humanity is to be searched for and depends on each decision taken every day, over the course of a lifetime.

In March 2017 Les Républicains were accused of anti-Semitism against their centrist opponent Emmanuel Macron, the party's secretary Bernard Accoyer apologizing, saying it had been wrongly interpreted. The right-wing candidate François Fillon condemned the caricature of Macron as a hookednosed capitalist, who was not Jewish but had worked for the Rothschild investment bank. The caricature of a hooked nose banker did evoke images from the 1930s that were used by the Nazis to condemn the Jews as part of a wider conspiracy. Like Geert Wilders in Holland, the far-right Front National's Marine Le Pen was gaining support in France. Trump's victory in America can be read as a global move towards the right, although in France support for the Front National has always been strong. In Britain far-right politics, as exemplified by the BNP, EDL, and then UKIP, have been absorbed into the mainstreams, shifting the agenda of the mainstream right even further to the right. Political parties have used digital technologies to reach out to voters, altering their messages, depending on the demographic. Tim Berners-Lee, known as the founder of the World Wide Web, in March 2017 condemned the manner in which the Internet was being used to threaten freedoms. This was a long way away from the utopian rhetoric used in the early days of the Internet.

Political parties were tracking potential voters through the monitoring of their choices. The same party was giving out different messages to different types of voter, altering the message to visit the audience. The audience's preferences were gained from their social media choices. While Berners-Lee finds this problematic, we can see this is just the nature of politics. For decades the Labour Party attempted to court business interests in the UK, for fear of being anti-business, while at the same time giving the impression it was on the side of the working class. It would be naïve to believe the Internet was a private zone, where monitoring did not take place. The harvesting of data on a huge scale is a fear the experts might 
have, but most users ignore this aspect of the Internet. There were 50,000 variations of political messages each day on Facebook during the 2016 US election. ${ }^{28}$ For Berners-Lee the problem was when users were redirected to fake news sites or messaging discouraging people from voting. This worked against Clinton and it was the demonization of Hillary Clinton that swung the election. Wikileaks and Julian Assange played a part in this, Assange meeting UKIP's Nigel Farage for discussions in March 2017.

Divisions between left and right were breaking down, and social media played a large part in this. Trump was globally renowned for his personal unpredictable use of Twitter, which was often aggressive. Owen Jones, in The Independent's top ten list of the most influential left-wing figures in Britain, had also been a prolific user of social media. The public display of animosity between figures across the political spectrum became even more a form of theatre. In 2016 Jones has been known specifically in Spain for his support of the left-wing political party Podemos, where the left gave up their entrenched position to collaborate with other parties. Jones was interested in finding a position where different sides could collaborate. The fact that he was not fixated on an ideology often meant he was on the receiving end of hatred, especially from those who believed Jeremy Corbyn could do no wrong.

Despite the impact he was creating globally, as a writer and journalist and political figure, Jones announced in March 2017 that he was moving off social media, other than to use it for the sharing of events and news. This was down to the hatred of his enemies, who were using these platforms to target him. Tim Berners-Lee had been speaking as a technologist when he warned of the dangerous situation the Internet was in by 2017. The space had become usurped by those who wanted to drown out the voices of those, like Jones, who believed in equality. In this sense, the neo-Nazis had won. Jones was driven from the debate, and up to this point he was one of the most articulate people of the left. This abuse included people telling him how they were going to murder and torturer him. This censoring was not just in social media but occurred in television interviews, GMTV host Piers Morgan, a known Trump sympathizer, shouting Jones down. This hatred was nothing new and had been building for some time and was explicitly related to neo-Nazism. This indicated how the phrase and accusation 'Nazi' can be used by both the left and the right.

In November 2016 David Duke, a well-known white separatist, Holocaust denier, and former Grand Wizard of the KKK, took to Twitter to attack Owen Jones directly. While later being a member of the Republican Party, Duke in the 1970s was a known member of the self-declared American 
Nazi Party. The level of conspiracy theory and beliefs propounded by Duke is comprehensive, but not unusual for American white separatists. Duke believes Jews are in control of the Federal Reserve Bank, the US federal government, Hollywood, and the media. He uses a variety of platforms such as his own website to promote the notion that homosexuality is also part of a Jewish conspiracy. A tweet sent 2:34 am, on 22 November 216 read, 'What's up with these homosexuals, like Owen Jones - pushing for Muslim immigration?' A loyal supporter of Trump and the latter's policy of 'taking America back', Duke had taken offence to Jones calling Trump a 'monster' listing all of Trump's faults, including racism and misogyny. As with Trump, it seems Duke was looking for a battle to create a theatre that attracted attention, but Jones did not take the bait. He then had a very low-key response, 'Oh look, I'm being dissed by a leading American Nazi. How very 2016.' This tweet was apt, summing up the current state of the world. Accused of being anti-Semitic because of his support for Palestine, Jones made a point of rejecting comparisons between Nazi Germany and the State of Israel. Even in that debate he has proven himself to be reasonable, and that was part of the problem for his detractors. Much of the hatred directed towards Jones came from those claiming to be from his own party. In this position, it was no wonder Jones left social media, as voices from all sides were attacking him.

Allegations and accusations of Nazism and neo-Nazism can be flung and are flung by all sides. While this attracts attention to certain figures, creating a theatre, the emphasis on personalities detracts from policies. By late March 2017 the Trump administration was floundering, then Trump accused Obama of wire-tapping. The debate moved into the strange Orwellian zone of what was actually meant by this comment, Trump declaring he did not mean Obama personally. At least, from Trump's perspective, these debates detracted from what Trump was doing on the ground, such as trying to remove ObamaCare, with 15 million people eligible for medical treatment in danger. Whether Trump personally believed in any of the policies or beliefs promoted by white separatists or neo-Nazis did not matter. He was still controlling the narrative. Globally, Trump attracted the most attention but his views were not the most extreme. In Holland, Geert Wilders had the stated policy of shutting down mosques, going one step further than Trump. This did have some similarity to the Nazi tactic of closing down synagogues.

The resurrection of the ideology that a strong man (or, in France's case, a woman) was necessary became the global direction politics was taking. From Turkey, to China, to America, to Spain, to name just a few countries, a sizeable part of the population believed that, for the sake of 
security and growth, personal freedom was not as important as a strong man in charge. In Germany some believed Angela Merkel was an ineffectual leader because she was flexible, especially in her approach to immigration. Despite the death of Franco in the 1970s, many believed having a leader like Franco was what Spain was missing. The older generation yearned for this form of leadership, nostalgically believing this offered clarity. As with the propaganda peddled by Steve Bannon concerning America in the 1960s, it was mainstream to believe, following the death of Franco, Spain went through a period of decay due to liberalization. Progress, especially regarding the rights of women and homosexuals, was not felt to be of benefit to the country by many of those looking for a strong leader. This relates to the view in Latin America of the benign dictator.

In Britain in 2017, Prime Minister Theresa May was criticized for not being strong enough, calling a snap election. From an early age the need for a strong leader is instilled in the population, through families, schools, universities, and then work and governments. Globally, there has been the view that groups of people, in any circumstance, need a strong person to fight their cause. This leads not to cooperation and collaboration, and long-term resilience, a position advocated by Owen Jones. An emphasis on single figureheads, driving blinkered ideologies, often flirting with fascism, drives a global economy that is the antithesis of stability. In Germany, the establishment saw Hitler initially as no more than a joke, and refused to collaborate. Once he started gaining support, using ruthless force, there was little choice. Parallels between the 1930s and our current period are not absolute, but practicalities triumph over ethics. Dutch parties claim they will never collaborate with Geert Wilders' party, but they might have to change their position. This sets a dangerous precedent. Theresa May has so far resisted working with Nigel Farage. In France, there have been claims that Marine Le Pen is not as right wing as people believe. Her brand of politics is the antithesis of Trump's, with her strong belief in state ownership of certain services.

Media headlines in March 2017 were claiming Russia's President Putin was the most powerful man in the world. Through the wars in Syria, the Crimea, and elsewhere, plus Russia's suspected intervention in the American elections and UK referendum on Europe, and certain policies, such as the removing of laws protecting women from domestic violence, Putin epitomizes the proto-fascist leader. As we saw in Chapter 1, there were suggestions that, even when it came down to something as trivial as football matches, Russia had sent trained hooligans to attack opposition supporters, especially English football fans. The British media enjoyed reporting this, 
and the Russian media denied this. Regardless of the truth, each related activity by Russia concerned projecting the image of a strong Russia. As with Brexit, it appears when given a choice people will often choose to remove their ability to choose. This suggests a herd mentality that is self-destructive. Neo-Nazism has this trait, flirting with apocalyptic rhetoric, rehashing old arguments concerning threats to the 'pure' race.

The notion of purity draws us to the conceptualizing of sex and it would be wrong to assume there is nothing outside of sexual misconduct. But it is also spurious to attack Deleuze and Guattari for illustrating sexuality is both physically and socially polymorphous, and that Nazism 'got fascists sexually aroused'. ${ }^{29}$ Culture and the media exponentially reflect on the debates explored here, indicating issues over Nazism and neo-Nazism and film and media are central to the way we understand ourselves in the contemporary world. These extreme beliefs have become part of the mainstream. This book has explained briefly how they always have been. They are intrinsic to the way we define ourselves through framing our group ontology, whether in versions of alignment to, or opposition from. Len Deighton's novel SS-GB is just one example of a cultural product drawing media attention, dramatized for television by the BBC, and broadcast in 2017. This explores a world, like The Man in the High Castle, where Germany has won the war. Of course, these fictions reflect on the present. In the first series of The Man in the High Castle the majority of the accents are American not German, and the German victory is celebrated like Thanksgiving. Fundamentally, good dystopian drama functions as a warning.

With a swift change of outfits and geography, could the Nazis be the evil empire, as in Star Wars or vice versa? Even the outfits in Star Wars, arguably the most globally recognized and popular franchise of all time, are drawn explicitly from Nazi iconography. Bifurcated ideological systems make the best drama only when moral dilemmas are drawn out via blurring clear divisions, and offering protagonists choices. Star Wars can also be 'read' as a commentary on radicalization. In $S S-G B$, Germans are holding the King of England captive but certain Nazis want to protect and free him. Deighton gets behind the divisions within the Nazi Party itself, with the SS at war with the army and various factions, and reveals how the British resistance utilizes these divisions. The moral dilemma of the protagonist, Archer of the Yard (Sam Riley), is emphasized in the fourth episode. Archer is a valued senior policeman, assisting the Nazis with their investigations of unexplained deaths. He has won the trust of his senior Nazi boss, who does not have an interest in politics, but does believe in the Nazi ideology of 'winners', and sees Archer as a 'winner'. 
This ideology is identical to the rhetoric spun out by business schools today, part of the winners-and-losers philosophy central to Donald Trump's propaganda. Ignoring all his business failures, commentators and voters believed a man supposedly good at business, and an apparent 'winner', would be good in the White House. What we mean by 'good' here is open to question. When given the chance to become a German, and therefore be a full Nazi Party member and save his family completely, Archer comments, 'Do I have a choice?' but he still says no. Archer's seemingly rhetorical question could be put to those dealing with Trump, Wilders, Putin, and the rest. Do we have a choice? There is a simple choice if we want to remain human. One debatable difference between an animal and a human is the latter's ability to make more deliberate self-reflective choices. This ability is not necessarily always an ability people choose to progress and maintain, abdicating their humanity. This suggests being human is not innate but a process that needs development, or least being humane can be described in this way. This human behaviour to not ultimately be free, and to abdicate responsibility, might paradoxically be a self-preservation device. But it lacks a wider humanity. Philosophers for centuries have contemplated the notion of free will, but when it comes down to it Archer of the Yard chooses to keep his humanity, even if this threatens his life and his family's life. If he loses his humanity what exactly does he achieve through this collusion with the Nazis. Would we do the same?

With the polarization of the left and the right there is an opportunity for neo-Nazis in all of their guises to further align themselves to the centre ground. This has not been something on the fringes, historically. If fascism normalizes itself the media has helped by shifting the focus away from how fascist policies have been mainstreamed. Identity is now the image. For postmodern thinkers this horror is celebrated as a reoccurring reality, as with Nietzsche's eternal recurrence of the same. For Nietzsche this eternal recurrence is overcome by willing its return. Part of the complexities can be summarized within Hegel's approach, where 'transcendence is infinity, that is, the impossibility of encompassing or totalizing alterity'. ${ }^{30}$ This is far removed from the homogeneity and binary positions advocated by the popular press and media, neo-Nazis, and politicians. Nazism and neoNazism have become ways in which we define ourselves, ontologically. Our central question has been whether this has always been in culture and societies, often remaining dormant, or whether it is only due to recent changes that this has come to the forefront. Globalization has been central to this. While some of these events are ubiquitously called terrorism, others are called nationalist activity linked to pride. 
Following murder at a 'Unite the Right' rally in August 2017, Trump refused to explicitly condemn white supremacists who had protested in Charlottesville, Virginia, due to the removal of a statue of Confederate General Robert E. Lee. Those fearing Trump's allegiance to the far right felt they had been proven correct when he also blamed so-called left-wing protestors, preaching to the press that there was always two sides to a story and anything else was fake news. As 2012 nominee Mitt Romney tweeted at 1:14 am, 16 August 2017, 'No, not the same. One side is racist, bigoted, Nazi. The other opposes racism and bigotry. Morally different universes.' After a 32-year-old woman was killed and nineteen others injured, 20-yearold James Alex Fields Jr of Maumee, Ohio, was arrested and charged with second-degree murder, malicious wounding and failure to stop for an accident involving death. Three people died on 12 August, including two state troopers monitoring the protest from a helicopter, plus 35 people had been injured in various confrontations during the rally. This was considered to be the largest white nationalist rally in a decade, but Trump's supporters stood by him, despite him being forced to disband the so-called American Manufacturing Council. His response overall was viewed by $\mathrm{CNN}$ as being a way for Trump to make political gain, taking America back, undoing 'decades worth of progress towards a freer and better country for all people'. ${ }^{11}$ White supremacy is part of the fabric of American life, racial terror and violence central to its history and comparing footage from racial attacks of 2017 and the 1960s the only real difference is the latter was filmed in black and white. ${ }^{32}$

Having commenced the initial work on this book eight years prior to Trump's presidentially victory, it was never my attention to give such an emphasis to Trump and the media. Clearly, it should be obvious now why this has been necessary. Trump's playing with the truth continues to be of relevance for the overall argument of this book, that Nazism and neo-Nazism is not at the fringes of media, culture and society, and never has been. For example, Trump's arguments, backed by the neo-Nazi David Duke, consist of claiming the removal of a statue of Robert E. Lee will lead to the removal of statues of Abraham Lincoln. There is no logic in this, and no connection between Lee and Lincoln. Despite this, it has been my argument throughout that postmodernism's assault on the one truth has been of benefit. This does not give strength to neo-Nazis who might deny the Holocaust. There is a more difficult question concerning what the Holocaust means.

As is recognized by historian John Lukacs, the pursuit of truth changes across time, including its conditions, circumstances, and practices. ${ }^{33}$ Through references to Bernard Schlink, Jacques Derrida, and William 
Burroughs, amongst others, the significance of language has been emphasized throughout this work, as has the use of apocalyptic rhetoric by politicians and theorists. Discussing American literature since 9/11, Richard Gray has stressed the 'strange dematerialization of the material'. In such a zone, the difference between the actual and artificial is wiped clean, and the real returns as artificial. Quoting Herbert Marcuse's notion of the return of the repressed, making up the 'tabooed and subterranean history of civilisation', there is the notion that this is a way to interpret the world after $9 / 11$. Silence reigns and speech is confounded, but Gray ties this into a movement since Romanticism concerning writing about loss. ${ }^{34}$ Taking this a step further, the loss is part of a deification of a prelapsarian world, where difference was unthinkable. In such a zone thinking itself does not and cannot take place as a separate act.

Writing about Ray Bradbury, whose book Fahrenheit 451 was adapted by François Truffaut and alluded to Nazism, Margaret Atwood notes he was descended from Mary Bradbury. She was a convicted witch in 1692 during the notorious Salem trials, a seminal trope in American history. Bradbury gets to the 'deep, dark, gothic core of America'. At the heart of the trials is the idea of the double. You are not who you are, but more significantly your neighbours are not who you think they are. Paranoia runs rampant. In the seventeenth century they are witches; in the eighteenth century they are traitors in the time of the revolution; in the twentieth they are communists; and in the twenty-first they are terrorists..$^{35}$ Atwood forgets to add they have always been the Jews. For the Nazis, the Jews were part of the demonic powers conspiring against their ascension to a state of semi-divine immortal harmony..$^{3}$ According to Fox News, neo-Nazis in the Charlottesville rally of August 2017 were chanting 'Jews will not replace us!'37 From 2007 to 2017 right-wing terror groups have accounted for 74 per cent of domestic terror incidents in America, with one credible analyst claiming the chance of a civil war breaking out in America in the next ten to fifteen years was as high as 60 per cent..$^{3}$ An emphasis on borders and territorial control arises, with right-wing politicians gaining support by asserting the paramount status of the ethno-national state. As recently as 2007 the reverse trajectory was predicted, with the prediction that the ethno-national state was in decline..$^{39}$ This reinstalling of the ethno-national state's importance can be viewed as a reaction to its threatened demise.

Throughout this book it is recognized the term 'Nazi' is a contested one, as is fascism. America has its own traditions, from the Klu Klux Klan established in the mid-nineteenth century, to the investigations into racial cleansing that inspired the Nazis, and even the term 'neo-Nazi' was in 
use in the $1940 .^{40}$ The American emphasis may be misleading, but with neo-Nazi groups in American gaining ground and media publicity this is appropriate. We have seen that even in remote places, with no real Jewish presence, neo-Nazi groups are also growing. The Jewish diaspora globally has to reconcile its own status of going beyond borders, breaking down the ethno-national state, with the weight given to the Jewish state of Israel which is the classic ethno-national state. ${ }^{41}$ Despite the alarm over the rightwing agenda of Trump and his connection to white separatists, it has been explained how this frequently functions as a smoke screen. Support from the extreme right is gained through airing extreme potential policies whilst getting into power. Then, once they have achieved power, their right-wing policies, which are still extreme, are then felt to be acceptable. In such a climate journalism and politics are transformed and often redundant, and the media struggles to hold politicians to account. As with history, in our struggle to understand Nazism and neo-Nazism in film and media we might find examples by which we consider our future actions, but there are no definitive templates. ${ }^{42}$

Our lack of an agreed understanding over Nazism and neo-Nazism may come down to our collective approach to any attempt at understanding collective and individual morality. Writing just three years before the new salaried employees who populated the cities of Weimar Germany fully embraced Hitler, Siegfried Kracauer showed how the National Board for Economic Viability in Weimar Germany had no place for the term 'human beings.' ${ }^{43}$ In this world, salaried office works were the new proletariat slaves, as he put it, fully embracing the notion of rationalization. The word rationalization has a contemporary ring to it, but was at the heart of Germany leading up to the Nazis taking control. There is a nurturing of uniformity and false consciousness in this period, along with the combined spurious claim that difference is allowed and promoted but fundamentally inertness reigns. ${ }^{44}$ Kracauer was writing in the 1920 s, but could be commenting on the contemporary period, which similarly has fostered a thirst for neo-Nazism. There has been no claim here of offering a deep insight into the human condition. Others have highlighted in a positive way the significance of postmodernism in the context of the Holocaust. ${ }^{45}$ Here our focus has been on Nazism and neo-Nazism in film and media, and popular culture by its very nature is postmodern. Teasing out some of the essential paradoxes of this has been within the scope of this book, but examining in detail the impact of certain thinkers is not.

As is now known, Martin Heidegger's Nazism was not a marginal affair, but his influence on theorists such as Jacques Derrida, Jacques Lacan, Michel 
Foucault, and all their disciples, is immense. ${ }^{46}$ The opening section to this book used a quotation from Homi Bhabha, who is in turn referencing Heidegger. This in itself could be conceived of as problematic, although using a Nazi to understand Nazism and neo-Nazism has some logic. René Girard has explained three core mechanisms governing social interaction: mimesis, with imitation being at the heart of all human behaviour; scapegoating, where collective guilt is placed onto victims then purged; and violence. ${ }^{47}$ This framework might explain some of the behaviour of neo-Nazi groups today, but it does not explain their global reach to cultures that are so different. In 1933 Wilhelm Reich claimed that fascism is the politically organized expression of the average human character structure and has nothing to do with race, nation or party but is 'general and international'. ${ }^{8}{ }^{4}$ The problem with this approach is that the patriarchal family structure is singularly blamed, sexual repression functioning not for moral edification (religion), or culture (Freud), but in Reich's view for the preservation of an authoritarian social regime. Attractive in its simplicity, this is too absolutist and universal, and ignores local variations. Even now some scholars maintain Nazism was sexually repressive, plus film, literature, journalism, and popular culture have emphasized Nazism's perversity. ${ }^{49}$ We saw in the previous chapter how local neo-Nazi groups in Asia gained strength from appearing to defend local interests against what is perceived to be the colonial oppression, such as that from China. This included sexual activity.

From an interview I had in 1996 with Margot Male, a former member of the Hitler Youth, it was clear to me she had seen herself as a victim when forced to work in an ammunitions factory. The status of the right-wing white victim has been explicated, along with exposing the underlying myth that now it is a justifiable time for them to rise up. When myths are demythologized, they can be understood not cosmologically, or even anthropologically, but existentially. ${ }^{50}$ The manner in which the extreme left and right coalesce over the notion of authenticity has been outlined. With neo-Nazism frequently being at the heart of culture and society it is difficult to separate out its traits. Both sides utilize terminology such as cleansing in the pursuit of their aims. This may involve ridding the earth of Nazis and neo-Nazis as part of a hunt narrative, or removing the 'other'. Aspects of how our current myths concerning identity and race stem from media discourse have been outlined. Writers for film, television and video games have incorporated Nazi themes but this often deadens understanding.

The media has at times constructed neo-Nazism from an ontological crisis. Despite or because of the reworking of Nazism, neo-Nazism and the death camps in film and media, often they appear even more unintelligible. 
But it has been argued this does not mean attempts at understanding should be relinquished. The need to understand these beliefs and associated events has not dissipated but only grown stronger. The media can function to replace any event with any other, offering the myths we live by and dangerously delineating moral boundaries. The threat from Holocaust denial is real, despite being exposed. Neo-Nazis have used the media, but deniers have often fallen because documentary footage is then used as evidence against them. This book has offered an approach suggesting that our forever ambiguous humanity is tied to certain choices. We can renounce our ability to choose, for reasons such as animalistic self-protection. This is a dehumanizing process, so what exactly are we protecting? 


\section{Notes}

\section{Chapter 1}

\begin{tabular}{ll} 
1. & Bhabha, 1 \\
2. & Rosenfeld \\
3. & Rattansi, 3 \\
4. & Camus, 2 \\
5. & Royle, 113 \\
6. & Insdorf, xi \\
7. & Lee (2005) \\
8. & LaCapra, 219 \\
9. & Lechte, 184 \\
10. & Beusch \\
11. & Beusch, i \\
12. & Maechler \\
13. & Rattansi \\
14. & Rattansi, 62 \\
15. & Rattansi \\
16. & Williams \\
17. & Williams \\
18. & Williams, 30 \\
19. & Williams, 30 \\
20. & Gullianotti, 23 \\
21. & Gullianotti, 24 \\
22. & King \\
23. & Pajaczkowska, 202 \\
24. & Drabble, 534 \\
25. & Berlet, 4 \\
26. & Drabble, 535 \\
27. & Drabble, 467 \\
28. & Drabble, 467 \\
29. & Vidal \\
30. & Vidal \\
31. & Vidal \\
32. & Peters, 5 \\
33. & Peters, 6 \\
34. & Peters, 13 \\
35. & Peters, 8 \\
36. & Peters, 12 \\
37. & Insdorf, xi \\
& \\
\hline
\end{tabular}

\section{Chapter 2}

1. Magilow, 2

2. Marhoefer

3. Magilow, 4

4. Magilow, 4

5. Magilow, 7

6. Herzog, 5

7. Sontag, 73-105

8. Sayre

9. Herzog, 11

10. Bradshaw

11. Hare

12. Hare

13. Dargis

14. Hare

15. Hammer, 101

16. Hare

17. Hare

18. Goldhagen, 459

19. Pink, 123

20. Althusser

21. Baudrillard (1994), 142

22. Nietzsche, 121

23. Derrida, 189

24. Lee (2014)

25. Jaspers

26. Wiesel

27. Adorno, 362

28. Derrida, 78

29. Derrida, 81

3o. Wiesel, 45

31. Wiesel, 48

32. Wiesel, 51

33. Wiesel, 81

34. Wiesel, 87

35. Wiesel, 101

36. Lee (1999), 195-231

37. Brody

38. Evans

39. Wolin, 306 


$$
\begin{array}{ll}
\text { 40. } & \text { Macnab } \\
\text { 41. } & \text { Cruz } \\
\text { 42. } & \text { McCarthy } \\
\text { 43. } & \text { Kirshner } \\
\text { 44. } & \text { Burchill } \\
\text { 45. } & \text { Spivak, 248 } \\
\text { 46. } & \text { Spivak, 248 }
\end{array}
$$

\section{Chapter 3}
1. Vermes, 4
2. Bergson, 27
3. Streeck
4. Vermes, $3^{2}$
5. Vermes, 43
6. Messofiore
7. Gross
8. Gross
9. Kristeva, 191
10. Vermes, 253

\section{Chapter 4}
1. Hegel, 11
2. Hegel, 11
3. Baudrillard (1994), 89
4. Mazzoni
5. Baudrillard (1994), 91
6. Baudrillard (1994), 91
7. Baudrillard (1994), 91
8. Baudrillard (1994), 91
9. Baudrillard (1994), 91
10. Baudrillard (1994), 93
11. Baudrillard (1994), 93
12. O'Sullivan, 128
13. Gray (2007), 68
14. Gray (2007), 69
15. Goldhagen, 89
16. Debord, 32
17. Baudrillard (1994), 89
18. Deleuze, 61
19. Dotzler, 171
20. Watson, 94
21. Watson, 55
22. Foster

23. Baudrillard (1994), $5^{0}$

24. Nash, $5^{1}$

25. Nash, $5^{1}$

26. Nash, $5^{1}$

27. Nash, 49

28. Nash, $5^{0}$

29. Lee (2009), 27

30. Nash, 29

31. Debord, 13

32. Baudrillard (1993), 79

33. Baudrillard (1993), 80

34. Baudrillard (1993), 80

35. Debord, 48

36. Baudrillard (1993), 86

37. Hand, 42

38. Hand, 42

39. Schroeder, 62

40. Schroeder, 86

41. Schroeder, 103

42. Schroeder, 103

43. Schroeder, 97

44. Schroeder, 60

45. Schroeder, 86

46. Lewis

47. Ahmed

48. Harkinson

49. Kershaw, 289

50. Eagleton, 206

51. Jones

52. Zingales

\section{Chapter 5}

1. Rattansi, 169

2. Rosen

3. Rattansi, 169

4. Rattansi, 169

5. Howard, 116

6. Navarro

7. Collyns

8. Wagner

9. Wagner

10. Parkin, 95 


\section{Chapter 6}

1. Gray (2011), 22

2. Price, 24

3. Lee (2009), 327

4. Lee (2009), 96

5. Atkins

6. Marin

7. Bullock, 80

8. Conrad, 8

9. Badiou, 401

10. Lee (2009), 324

11. Ohler, 88

12. Hand, 42

13. Hand, 42

14. Schroeder, 62

15. Hand, 86

16. Hand, 103

17. Hand, 103

18. Hand, 97

19. Hand, 60

20. Hobsbawm, 235

21. Murdoch, 269-280

22. Segal (2000), 74

23. Glassner (1999)

24. Laitman
25. Laitman

26. Goldhagen

27. Foster

28. Gunaratna

29. Bookchin, 198

30. Schroeder, 105

31. Cillizza

32. Moore, 29

33. Lukacs, 27

34. Gray (2011), 13-14

35. Atwood

36. Gray (2007), 204

37. Brockes

38. Brockes

39. Beller, 117

40. Poole, 17

41. Beller, 117

42. Arnold, 120

43. Kracauer (1959), 43

44. Kracauer (1959), 81-84

45. Eaglestone

46. duBois, 139

47. Girard, 179-184

48. Robinson, 46-47

49. Herzog, 11

50. Segal (2004), 48-49 



\section{Bibliography}

Adorno, Theodor (2004) Negative Dialectics (London: Routledge)

Ahmad, Talat (2012) 'Racism: A Very British Institution', Socialist Review, February, No.366, http:// www.socialistreview.org.uk/366/racism-very-british-institution (accessed 18 April 2017)

Althusser, Louis (1969) For Marx (London: Penguin)

Atkins, Williams (2017) 'Between Great Fires', Granta, 8 February, 138: Journeys, http://www. granta.com/between-great-fires/ (accessed 18 April 2017)

Atwood, Margaret (2017) 'Voyage to the Otherworld: A New Eulogy for Ray Bradbury', The Paris Review, 15 August, http://www.theparisreview.org/blog/2017/08/15/voyage-to-theotherworld-a-new-eulogy-for-ray-bradbury/ (accessed 17 August 2017)

Baddiel, David (2004) The Secret Purposes (London: Little, Brown)

Badiou, A. (2004) Infinite Thought: Truth and the Return to Philosophy, trans. O. Feltham and J. Clemens (London: Continuum)

Bainbridge, Beryl (1991) Young Adolf (London: Penguin)

Baudrillard, Jean (1993) The Transparency of Evil: Essays on Extreme Phenomenon, trans. James Benedict (London: Verso)

Baudrillard, Jean (1994) Simulacra and Simulation, trans. Sheila Faria Glaser (Ann Arbor: University of Michigan Press)

Baudrillard, Jean (2007) Fragments: Cool Memories III, 1990-1995, trans. Emily Agar (London: Verso)

Baudrillard, Jean (2013) The Intelligence of Evil, trans. Chris Turner (London: Bloomsbury)

Beller, Steven (2006) Antisemitism (Oxford: Oxford University Press)

Bergson, Henri (1991) Matter and Memory, trans. N.M. Paul and W.S. Palmer (New York: Zone Books)

Berlet, Chip, and Matthew N. Lyons (2016) Right-Wing Populism in America: Too Close for Comfort (New York: The Guildford Press)

Bennett, Andrew, and Nicholas Royle (1999) Introduction to Literature, Criticism and Theory (Harlow: Pearson)

Beusch, Danny (2008) 'Queering Nazism or Nazi Queers? A Sociological Study of an Online Gay Nazi Fetish Group', PhD thesis, University of Warwick

Bhabha, Homi K. (2009) The Location of Culture (London: Routledge)

Bob, Clifford (2012) The Global Right Wing and the Clash of World Politics (Cambridge: Cambridge University Press)

Bookchin, Murray (1995) Re-Enchanting Humanity (London: Cassell)

Boyne, John (2008) The Boy in the Striped Pyjamas (London: Definitions)

Bradshaw, Peter (2016) 'McKellen Mesmerises in a Terrific Regal Thriller', The Guardian, 21 April, http://www.theguardian.com/film/2016/apr/21/Richard-III-review-ian-mckellen-loncraine (accessed 16 August 2017)

Branigan, T. (2010) 'Mongolian Neo-Nazis: Anti-Chinese Sentiment Fuels Rise of Ultranationalism', The Guardian, 2 August, http://www.theguardian.com/world/2010/aug/o2/ mongolia-far-right (accessed 18 April 2017)

Brockes, Emma (2017) 'Fox News backs Trump. Trump backs Nazis. Awkward', The Guardian, 17 August, https://www.theguardian.com/commentisfree/2017/aug/17/trump-nazis-foxnews?CMP=Share_iOSApp_Other (accessed 17 August 2017) 
Brody, Richard (2015) 'Son of Saul and the Ungraspable Horrors of Auschwitz', The New Yorker, 30 December, http://www.newyorker.com/culture/richard-brody/son-of-saul-and-theungraspable-horrors-of-auschwitz (accessed 16 August 2017)

Bullock, Alan (1991) Hitler: A Study in Tyranny (London: Harper Perennial)

Burchill, Julie (2016) 'Reasons Why Muslims Are Not "the New Jews"', The Jewish Chronicle, 18 February, https://www.thejc.com/comment/comment/reasons-why-muslims-are-notthe-new-jews-1.59956 (accessed 18 April 2017)

Camus, Jean-Yves, and Nicolas Lebourg (2017) Far-Right Politics in Europe, trans. Jane Marie Todd (Cambridge, MA: Harvard University Press)

Cillizza, Chris (2017) ‘Donald Trump's Failure in Charlottesville Wasn't Political - It Was Moral', 16 August, http://www.edition.cnn.com/2017/08/15/politics/donald-trump-press-conference/ (accessed 16 August 2017)

Cohn, Norman (2001) Cosmos, Chaos and the World to Come: The Ancient Roots of Apocalyptic Faith (New Haven: Yale University Press)

Collyns, Dan (2012) 'Peru's Nazi Party Leader Believes Even the Conquistadors Were Jews', The Guardian, 16 August, https://www.theguardian.com/world/2012/aug/16/peru-naz-partyleader-believes-conquistadors-jews (accessed 18 April 2017)

Conrad, Peter (2007) 'Misfits on a Mission to Delete Us All', The Observer, 30 December, https:// www.theguardian.com/theobserver/2007/dec/3o/features.review37 (accessed 6 December 2017)

Cruz, Lenika (2016) 'Miss Peregrine's Home for Peculiar Children Is All Spectacle and No Heart', The Atlantic, 1 October, http://www.theatlantic.com/entertainment/archive/2016/10/missperegrines-home-for-peculiar-children/501914 (accessed 18 April 2017)

Dargis, Manohla (2008) 'Innocence Is Lost in Postwar Germany', New York Times, 9 December, https://www.nytimes.com/2008/12/10/movies/1oread.html (accessed 16 August 2017)

Debord, Guy (1998) Comments on the Society of the Spectacle, trans. Malcolm Imrie (London: Verso)

Deleuze, Gilles (2006) Bergsonism, trans. Hugh Tomlinson and Barbara Habberjam (New York: Zone Books)

Derrida, Jacques (2004) Writing and Difference, trans. Alan Bass (London: Routledge)

Donald, James, and Ali Rattansi (1993) 'Race', Culture \& Difference (London: Sage)

Dotzler, Bernhard J. (2012) 'Programmed Violence: On the Object of Media Studies', Cultural Politics, 8(2), 171-191

Drabble, John (2003) 'Neo-Nazis', in Conspiracy Theories in American Culture, ed. Peter Knight (California: ABC-Clio), 533-536

duBois, Page (1991) Torture and Truth (London: Routledge)

Eaglestone, Robert (2008) The Holocaust and the Postmodern (Oxford: Oxford University Press)

Eagleton, Terry (2011) Why Marx Was Right (New Haven: Yale University Press)

Edmundson, Mark (2008) The Death of Sigmund Freud:Fascism, Psychoanalysis and the Rise of Fundamentalism (London: Bloomsbury)

Evans, Richard (2015) The Third Reich in History and Memory (London: Little Brown)

Foster, Alice (2017) 'Will Geert Wilders Win the Dutch Elections?' Express, 14 March, http://www. express.co.uk/news/politics/754516/Dutch-election-2017-will-Geert-Wilders-win-latestpolls-Netherlands-polls (accessed 18 April 2017)

Girard, R. (2005) Violence and the Sacred, trans. Patrick Gregory (London: Continuum)

Glassner, Barry (1999) The Culture of Fear (New York: Basic Books)

Goldhagen, Daniel Jonah (1996) Hitler's Willing Executioners: Ordinary Germans and the Holocaust (New York: Alfred A. Knopf) 
Gray, John (2007) Black Mass: Apocalyptic Religion and the Death of Utopia (London: Penguin) Gray, Richard (2011) After the Fall: American Literature since 9/11 (Oxford: Wiley-Blackwell)

Gross, Daniel A. (2015) 'Führer Humor: The Art of the Nazi Comedy', The Atlantic, 20 December, http://www.theatlantic.com/entertainment/archive/2015/12/look-whos-back-nazi-comedies/420081/ (accessed 18 April 2017)

Grosz, Stephen (2014) The Examined Life: How We Lose and Find Ourselves (London: Vintage)

Guillianotti, Richard, ed. (2004) Football, Violence and Social Identity (London: Routledge)

Gunaratna, Shankia (2017) 'Web Inventor Tim Berners-Lee on the Biggest Problems with the Internet Today', CBS News, 13 March, https://www.cbsnews.com/news/web-inventor-timberners-lee-biggest-problems-internet-fake-news-privacy/ (accessed 18 April 2017)

Haberman, Maggie (2016) 'Donald Trump Disavows David Duke's Remarks on Jewish Extremists', New York Times, 5 May 2016, http://www.nytimes.com/politics/first-draft/2016/05/05/ donald-trump-is-pressured-to-reject-david-dukes-remarks-on-jewish-extremists/ (accessed 18 April 2017)

Hammer, Martin (2012) Francis Bacon and Nazi Propaganda (London: Tate Publishing)

Hand, Sean (2009) Emmanuel Levinas (London: Routledge)

Hare, David (2008) 'Truth and Reconciliation', The Guardian, 13 December, http://www.theguardian.com/film/2008/dec/13/schlink-winslet-hare-reader (accessed 18 April 2017)

Harkinson, Josh (2016) 'Meet the White Nationalist Trying to Ride the Trump Train to Lasting Power', Mother Jones, 27 October, http://www.motherjones.com/politics/2016/10/richardspencer-trump-alt-right-white-nationalist (accessed 18 April 2017)

Hegel, G. (1993) Introductory Lectures on Aesthetics, trans. B. Bosanquet (London: Penguin)

Herzog, Dagmar (2005) Sex after Fascism:Memory and Morality in Twentieth-Century Germany (Princeton: Princeton University Press)

Hobsbawm, Eric (1991) Age of Extremes: The Short Twentieth Century, 1914-1991 (London: Abacus, 1991)

Howard, Michael (2002) The First World War (Oxford: Oxford University Press)

Insdorf, Annette (1989) Indelible Shadows: Film and the Holocaust (Cambridge: Cambridge University Press)

Jaspers, Karl (2000) The Question of German Guilt, trans. E.B. Ashton (New York: Fordham University Press)

Jones, O. (2016) Donald Trump: The Rhetoric (London: Eyewear)

Keneally, Thomas (1983) Schindler's Ark (London: Coronet)

Kershaw, Ian (2008) Hitler (New York: W.W. Norton \& Co.)

King, John (2004) The Football Factory (London: Vintage)

Kirshner, Sheldon (2016) 'New Netflix Series Focuses on Neo-Nazis in Germany', Times of Israel, 11 July, blogs.timesofisrael.com/new-netflix-series-focuses-on-neo-nazis-in-germany (accessed 16 August 2017)

Kracauer, Siegfried (1959) From Caligari to Hitler: A Psychological History of the German Film (New York: Noonday Press)

Kracauer, Siegfried (1998) The Salaried Masses: Duty and Distraction in Weimar Germany, trans. Quintin Hoare (London: Verso)

Kristeva, Julie (1991) Strangers to Ourselves, trans. Leon S. Roudiez (New York: Columbia University Press)

LaCapra, Dominick (2001) Writing History, Writing Trauma (London: Johns Hopkins University Press)

Laitman, Michael (2017) 'Can There Be Nazism in America?' Jerusalem Post, 2 March, https:// www.jpost.com/Opinion/Can-there-be-Nazism-in-America-482934 (accessed 18 April 2017) 
Lasch, Christopher (1991) The Culture of Narcissism: American Life in An Age of Diminishing Expectations (New York: W.W. Norton \& Co.)

Lechte, John (1994) Fifty Key Contemporary Thinkers: From Structuralism to Postmodernity (London: Routledge)

Lee,Jason (1999) The Metaphysics of Mass Art-Cultural Ontology, Volume Two:Indigenous Peoples of the Americas and the Psychology of the Observer in U.S. Film (New York: Edwin Mellen Press)

Lee, Jason (2005) Pervasive Perversions (London: Free Association Books)

Lee, Jason (2009) Celebrity, Pedophilia, and Ideology in American Culture (New York: Cambria)

Lee, Jason (2014) The Psychology of Screenwriting (London: Bloomsbury)

Levenda, Peter (2002) Unholy Alliance: A History of Nazi Involvement with the Occult (London: Bloomsbury)

Levine, Suzanne Jill (2000) Manuel Puig and the Spider Woman: His Life and Fictions (London: Faber and Faber)

Lewis, Paul (2010) 'Blair Peach Killed by Police at 1979 Protest, Met Report Finds', The Guardian, 27 April,http://www.theguardian.com/uk/2010/apr/27/blair-peach-killed-police-met-report (accessed 18 April 2017)

Lukacs, John (2011) The Future of History (New Haven: Yale University Press)

Macnab, Geoffrey (2016) 'Miss Peregrine's Home for Peculiar Children review: Everything You Want from a Tim Burton Movie', The Independent, 29 September, http://www.indepedendent. co.uk/arts-entertainment/films/reviews/miss-peregrines-home-for-peculiar-childrenreview-everything-you-want-from-a-tim-burton-movie-a7336906.html (accessed 18 April 2017)

Maechler, Stefan (2001) The Wilkomirski Affair: A Study in Biographical Truth (London: Picador)

Magilow, Daniel H., Elizabeth Bridges and Kristin T. Vander Lugt (2012) Nazisploitation! The Nazi Image in Low-Brow Cinema and Culture (London: Continuum)

Marhoefer, Laurie (2015) Sex and the Weimar Republic: German Homosexual Emancipation and the Rise of the Nazis (Toronto: Toronto University Press)

Marin, Louis (1993) 'Frontiers of Utopia: Past and Present', Critical Inquiry, Vol. 19, No. 3, 333-347

Mazzoni, Guido (2017) Theory of the Novel, trans. Zakiya Hanafi (Cambridge, MA: Harvard University Press)

McCarthy, Todd (2016) 'Miss Peregrine's Home for Peculiar Children: Film Review', Hollywood Reporter, 25 September, http://www.hollywoodreporter.com/review/miss-peregrines-homefor-peculiar-children-932109 (accessed 4 April 2017)

Messofiore, Gianluca (2015) 'Adolf Hitler Really Did Only Have One Ball According to Unearthed Medical Archives', International Business Times, 18 December, http://www.ibtimes.co.uk/ adolf-hitler-really-did-only-have-one-ball-according-unearthed-medical-archives (accessed 16 August 2017)

Moore, N. (2017) 'Overt Racists Are Easy to Spot: America's Insidious Racism Is a Greater Challenge', The Observer, 20 August, 29

Mott, Tony (2013) 1001 Videogames You Must Play before You Die (London: Cassell)

Murdoch, Iris (1973) The Bell (London: Penguin)

NamRights (2012) 'Hitlerism Lives in Namibia 22 Years after Independence', http://www.nshr. org.na/index.php? module=News\&func $=$ display\&sid $=1854($ accessed 18 April 2017)

Nash, David (2016) Witches and Witchcraft (Oxford: Shire Publications)

Navarro, Lygia (2007) 'The Rise of Neo-Nazism in Chile', Centre for Latin American Studies, University of California, Berkeley, Summer Report, http.//www.clas.berkeley.edu/research/ rise-neo-nazism-chile (accessed 18 April 2017)

Nietzsche, Friedrich (1983) Untimely Meditations (Cambridge: Cambridge University Press) 
Ohler, Norman (2016) Blitzed: Drugs in Nazi Germany, trans. Shaun Whiteside (London: Allen Lane)

O’Sullivan, Tim, John Hartley, Danny Saunders, Martin Montgomery and John Fiske (1994) Key Concepts in Communication and Cultural Studies (London: Routledge)

Pajaczkowska, Claire, and Lola Young (1993) 'Racism, Representation, Psychoanalysis', in 'Race', Culture \& Difference, eds. James Donald and Ali Rattansi (London: Sage), 198-219

Parkin, Simon (2014) An Illustrated History of ${ }_{15}$ 1 Video Games (London: Lorenz Books)

Peters, Rikke Alberg 'Mediatized Extreme Right Activism and Discourse: The Case of the Immortals', Media@LSE Working Paper Series, www.lse.ac.uk/media@lse/research/mediaWorkingPapers/pdf/WP32-FINAL.pdf (accessed 18 April 2017)

Pink, Thomas (2004) Free Will (Oxford: Oxford University Press)

Poole, Steven (2017) 'On Words: Alt-right, alt-left, Centrist - The Political Rhetoric of Hate after Charlottesville', The Guardian, 18 August, https://www.theguardian.com/books/2017/aug/18/ steven-poole-words-charlottesville-alt-right-alt-left (accessed 6 December 2017)

Price, Stuart, and Ruth Sanz Sabido, eds. (2015) Contemporary Protest and the Legacy of Dissent (London: Rowman \& Littlefield)

Rattansi, Ali (2007) Racism (Oxford: Oxford University Press)

Robinson, P. (1969) The Freudian Left: Wilhelm Reich, Gaza Roheim, and Herbert Marcuse (New York: Harper \& Row)

Rosen, Michael (2014) 'Fascism: I Sometimes Fear ...', Michael Rosen Blog, http://www.michaelrosenblog.blogspot.co.uk/2014/05/fascism-i-sometimes-fear.html (accessed 22 August 2017)

Rosenfeld, Gavriel (2014) Hi Hitler! How the Nazi Past Is Being Normalized in Contemporary Culture (Cambridge: Cambridge University Press)

Sayre, Nora (1974) 'The Night Porter: Portrait of Abuse', New York Times, 2 October, http://www. nytimes.com $/$ movie/review?res=9Bo2 $\mathrm{E}_{3} 8 \mathrm{EF}_{3} \mathrm{ABC}_{4} \mathrm{~A}_{53} \mathrm{DFB} 667838 \mathrm{~F} 669 \mathrm{EDE}$ (accessed 16 August 2017)

Schlink, Bernhard (1997) The Reader, trans. Carol Brown Janeway (London: Phoenix)

Schlink, Bernhard (2009) Homecoming, trans. Michael Henry Heim (London: Phoenix)

Schroeder, Brian (1996) Altared Ground: Levinas, History, and Violence (London: Routledge)

Sebald, W.G. (2002) Austerlitz, trans. Anthea Bell (London: Penguin)

Segal, Julia (2000) Phantasy (Cambridge: Icon)

Segal, Robert (2004) Myth (Oxford: Oxford University Press)

Sontag, Susan (1980) Under the Sign of Saturn (New York: St Martin's Press)

Spivak, Gayatri Chakravorty (1987) In Other Worlds: Essays in Cultural Politics (London: Methuen) Streeck, Wolfgang (2016) 'Scenario for a Wonderful Tomorrow', London Review of Books, Vol. 38 , No. 7, 31 March, 7-10

Szpilman, Władysław (1999) The Pianist, trans. Anthea Bell (London: Victor Gollancz)

Vermes, Timur (2014) Look Who's Back (London: Quercus)

Vidal, Gore (2008) 'The Meaning of Timothy McVeigh', Vanity Fair, 10 November, http://www. vanityfair.com/news/2001/og/mcveigh200109 (accessed 18 April 2017)

Virilio, Paul (1994) The Vision Machine, trans. Julie Rose (Bloomington: Indiana University Press)

Wagner, J.S. (2010) 'Nazi Hunters: The Struggle for the Punishment of Nazi Crimes', PhD thesis, University College London

Watson, T.J. (2015) 'Audiovisual Violence and Editorial Manipulation: The Relationship between Violent Image-Content and Violent-Image Form', PhD thesis, University of Northumbria

Wiesel, Elie (2006) Night, trans. Marion Wiesel (London: Hill and Wang)

Williams, John M., Eric Dunning and Patrick J. Murphy (2014) Hooligans Abroad: The Behaviour and Control of English Fans in Continental Europe (London: Routledge) 
Wodak, Ruth (2016) The Politics of Fear: What Right-Wing Populist Discourses Mean (London:Sage) Wolin, Richard (2004) The Seduction of Unreason: The Intellectual Romance with Fascism from Nietzsche to Postmodernism (Princeton: Princeton University Press)

Zingales, Luigi (2016) 'Donald Trump, Crony Capitalist', New York Times, 23 February, http:// www.nytimes.com/2016/02/23/opinion/campaign-stops/donald-trump-crony-capitalist. html (accessed 18 April 2017)

Žižek, Savoj (2011) Living in the End Times (London: Verso) 


\section{Index}

Adorno, Theodor 53

Africa 14, 20, 33, 119-120, 123, 127-128, 157

alt-right 29-30, 107-108, 111, 113-114, 130, 164, 174-175, 195, 197

American Nazi Party (ANP) 28

Arab Spring 103

Arendt, Hannah 12, 20, 52, 124, 127

Artaud, Antonin 97, 147

Asia 5, 14, 20, 72, 79, 108, 119-120, 122-126, 135, 154,187

Australia 11, 18, 25, 115, 160

Austria 22, 79-82, 97, 115-116, 16o-161, 175, 178

Bacon, Francis 46, 65, 94, 195

Badiou, Alain 64, 148, 191, 193

Ballard, J.G. 166

Bannon, Steve 29, 87, 108-114, 143-144, 150, $173-174,176,181$

Bataille, George 147

Baudrillard, Jean 14, 64, 77, 89-94, 96-98, 104, 106-107, 115, 189-190, 193

Beckett, Samuel 53

Belgium 22, 24, 80, 127, 169

Benigni, Roberto 12, 13, 66

Bergson, Henri 14, 76, 89, 94-95, 19o, 193-194

Berlusconi, Silvio 80,116

Bhabha, Homi 3

Bin Laden, Osama 144

Bowie, David 16, 75, 198, 135

Breivik, Anders 11

Britain First 23, 49, 103, 154, 170

British National Party (BNP) 17, 21, 24-25, 34, 85,154

Brooks, Mel 13, 75, 81

Buddhist 104

Burroughs, William 53

Bush, George W. 144

Carroll, Noel 92

Cavani, Liliana 42-43

Channel $485,111,152,155,173$

child abuse $13,16,34,129,163$

Chile 128-129, 197

China 108, 111, 118, 122, 126-127, 164, 173, 180, 187

Christian 11, 28, 30, 66, 92, 99

Cleese, John 81,83

Cobb, Craig 27, 32-33-35, 37, 177

Corbyn, Jeremy 141, 16o, 173, 179

Cox, Jo 10, 26, 154, 162, 165-166

cult 99

Cyprus 127

Czech Republic 80

Dabydeen, David 7,168

Davis, Phil 12, 45, 171
Debord, Guy 77, 100-101, 115, 190, 194

Deleuze, Gilles 14, 93, 147, 194

Derrida, Jacques 14-15, 90, 106, 148, 184, 186, 189,194

Descartes, René 102, 151

diaspora 126, 132, 138, 186

Dick, Philip K. 103, 107, 136

Drumer, Akiba 56

Duke, David 19, 113, 179, 184, 195

Eichmann, Adolf 47, 134

Eliot, T.S. 99

English Defence League (EDL) 11, 17, 25, 34, 124

environmentalism 120,125

Evans, Richard 63

Farage, Nigel 26, 87, 149, 157, 161, 176, 179, 181 Federal Bureau of Investigation (FBI) 34-36, 45,162

Ford, Henry 130

Foster, Hal 96

Foucault, Michel 106, 187

Fox News Channel 115, 185, 193

Fransen, Jayda 103

Freud, Sigmund 81-83, 92, 107, 138, 147, 149, 187, 194

\section{Ganz, Bruno 75}

Girard, René 187, 191, 195

globalization 5, 9-10, 34-36, 112, 119, 121-139, 164,184

Goldman, Jane 65

gothic 93,185

Grey Wolves 120, 126-127

Griffin, Nick, 17, 85, 87, 157, 163, 177

Hegel, George W.F. 89, 92, 101, 108, 151, 177, 183, 190, 195

Heidegger, Martin 42, 108, 158, 186

Hindus 125

History Channel 41, 62, 175

Iran 121

Israel 14-16, 19, 30, 46-47, 58, 73, 79, 106, 112, 114, $121,124,127,130,134,155,157-158,180,186,195$

Japan $80,135,138$

Jaspers, Karl $5^{2}$

Klu Klux Klan (KKK) 19, 26, 106, 113, 185

Koresh, David 34

Kristeva, Julia 14, 75, 84, 190, 196

Laing, R.D. $5^{1}$

Lasch, Christopher 90 
Latin America 120

Lawrence, D.H. 51, 159, 170

Le Pen, Jean-Marie 18

Le Pen, Marine $18,160,178,181$

Levi, Primo 9, 16, 46

Levinas, Emmanuel 7, 12, 14, 51, 89, 101-102, 148, $15^{1-152,156,169,195,197}$

Luxembourg 80

madness 78-79, 106-107, 166

Malaysia 120, 126

Marcuse, Herbert 185, 197

Marxist 50

May, Theresa $73,142,150,157,181$

McLuhan, Marshall 100

McVeigh, Timothy $34-38,165,198$

Mediaset 81

Merkel, Angela 78, 80, 105, 160-161, 175, 181

Mongolia 120, 124-126, 193

Mossad 134

Murdoch, Rupert 115, 163, 191, 197

Muslim 19, 71-73, 87, 103, 108, 119-120, 125, 144, $150,165,168,174,194$

Namibia 120, 127-128, 197

National Alliance $27,29-30$

National Front (NF) 17, 20-21, 24-25, 149

National Socialist Association (NSA) 21, 128

National Socialist Underground (NSU) 28, 66, 69

Nemes, László 42, 58

Netflix 33, 66, 77, 80, 104, 150, 155, 195

Netherlands 22, 80, 115, 127, 175, 194

Nietzsche 50-51, 63-64, 90, 97, 188, 144, 183, 189, 197-198

North Korea 92, 108, 157, 164

occult $98-99,128,196$

Orwell, George 64

Palin, Sarah 40, 110

Parker, Alan 42

Periscope 100

Peru 120, 129, 130, 135, 194

postmodern 11, 16, 41, 61-62, 83, 89, 91, 116, 137, $146-147,183-186,194,196,198$

Powell, Enoch 21, 167

psychosis 59,79

psychotic 78,166

Reform Party 113

rhizomatic 93-95, 104
Rosenfeld, Gavriel D. 10, 189, 197

Russia 18, 20-24, 33, 100, 108-109, 126, 130-131, $135,146,156,167,169,181-182$

science fiction $38,64,156-157$

sexual $13,15-16,23,34,39,41-43,47-48,52,54$,

$82,111,125,129,147,159,174,180-182,187,196$

Shakespeare, William 12, 40, 82

Singer, André 98

skinhead 21, 26, 35, 44, 69, 119, 127, 148, 167

Sontag, Susan 42,189, 197

South Africa 11, 25, 128

Spencer, Richard 107-108, 111, 114, 164, 195

Spielberg, Steven 13, 6o, 151

subcultures 69

Sweden 120,156

Syria $80,103,121,127,181$

Taiwan $80,120,122,130$

Tarantino, Quentin 15, 40, 6o-61, 65-66, 147, 151

Technology 9, 11, 31, 33, 44, 77-78, 95, 133, 141, 146

Tequila, Tila 108

Trotsky, Leon 144, 162

Trump, Donald 5, 9-10, 12, 18-19, 26-34, 40, 75, 8o, 87, 90-92, 97, 99-100, 105-130, 138, 141-145, $148,151,156-186,193-195,198$

Turkey 120, 126-127, 16o, 175-176, 180

Twitter 36, 91, 100-103, 111-112, 115, 142, 170, 179

uncanny 6o, 93-94, 144, 147, 153

United Kingdom Independence Party (UKIP) $24-27,31,82,86,106,149-150,157,172$

United Nations 73, 110, 121

Verhoeven, Paul 42

Vidal, Gore 34-36, 198

Weber, Max 72

White, Hayden 12

White Swastikas 124

Wiesel, Elie 12, 38, 52, 55-58, 61, 189, 198

Wilders, Geert 171-183, 194

Wilkomirski, Binjamin 15, 196

Wolin, Richard 62

Wotanism 11

YouTube $36,38,41,44,69,77,83,134,146,152$, $15^{6}$

Žižek, Slavoj 137, 169, 198 